\title{
Identifying the Mechanism of Action of Bioactive 1,2-Cyclopropyl Carbohydrates
}

\author{
Loïc Lassueur
}

A thesis submitted to Victoria University of Wellington in partial fulfillment of the requirements for the degree of Master in Biomedical Science

2015

TE WHARE WĀNANGA O TE ŪPOKO O TE IKA A MĀUI

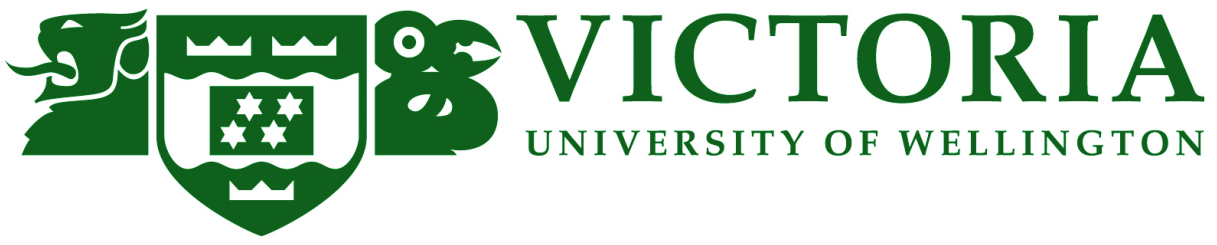




\begin{abstract}
Cyclopropanes and carbohydrates have long been used in the field of drug development. Previous work has shown that 1,2-cyclopropyl carbohydrates display bioactivity in both HeLa cancer cell lines ${ }^{1}$ and in yeast ${ }^{2}$ with a tentatively proposed mechanism of inhibition occurring through an enzymatic cyclopropane ring opening reaction and subsequent formation of a covalent bond with a target enzyme. ${ }^{2}$
\end{abstract}

A small library of 1,2-cyclopropyl carbohydrate derivatives were synthesised based on known pharmacophores to examine further the potential mechanism of inhibition of such compounds and confirm the occurrence of enzyme-catalysed cyclopropane ring-opening reactions. Initial synthetic efforts were focused on the synthesis of the 1,2-dichlorocyclopropyl carbohydrate 23, which, through the optimisation of an essential C-6 detritylation reaction, was achieved in moderate yields of $32 \%$ over 7 steps. Following this, the ethoxycarbonyl substituted 1,2-cyclopropyl carbohydrate 54 was synthesised over 7 steps in a $22 \%$ yield through a rhodium acetate-catalysed addition of ethyl diazoacetate (49) to the glucal substrate 40. It was envisioned that if enzymatic cyclopropane ring-opening was occurring to form a C-7 carbanion, this would in turn be stabilised through the potential enolate formation of $\mathbf{5 4}$. Use of $N, N$ ditosylhydrazine in the synthesis of propargyl diazoacetate (58) followed by a rhodium acetate-catalysed cyclopropanation of $\mathbf{5 8}$ with substrate $\mathbf{4 0}$ resulted in the successful synthesis of $\mathbf{6 1}$ over 7 steps in a total yield of $9 \%$. The incorporation of the propargyl substituent in $\mathbf{6 1}$ was introduced as a molecular probe in an attempt to isolate the target protein through an affinity purification procedure. The bioactivity of the propargyl derivative $\mathbf{6 1}$ was consistent with the synthesised compounds 23 and $\mathbf{5 4}$. It was proposed that these compounds undergo an enzymatic cyclopropane ring-opening reaction accompanied with a clear diastereoselective preference for the $\alpha$-stereoisomer of the cyclopropane ring, consistent with a target-based activation of the compounds.

Chemical genetic analysis of the resulting bioactive compounds was undertaken using a deletion mutant array of Saccharomyces cerevisiae to elucidate a potential mechanism of action. Analysis of the results showed that, of the 4800 homozygous 
deletion strains tested in the high-throughput screens, a total of 122 strains were found following validation to sensitise and 68 to give resistance against 23 and $\mathbf{5 4}$. These sensitive and resistant mutants were subjected to a validation assay. Following validation, genes whose deletion led to sensitivity or resistance were then subjected to gene ontology term enrichment analysis which showed enrichment in the cytosolic ribosome, SNARE complex and SNAP receptor activity for resistant strains and enrichment in endoplasmic reticulum and endomembrane systems was found for the sensitive strain. Genes whose deletion sensitised to both compounds showed strong enrichment in cellular protein localisation, intra-golgi vesicale-mediated transport and the endomembrane system.

Target identification and isolation were attempted through an affinity purification procedure using compound $\mathbf{6 1}$ and an azide-modified agarose resin. However, this was without success, either through inaccessibility of the alkyne of the target probe or because the target resides in the membrane-associated fraction which was discarded prior to treatment with the probe.

This study suggests that the 1,2-cyclopropyl carbohydrates synthesised function through a cyclopropane ring-opening reaction, assisted by an enzymatic nucleophile. Chemical genetic analysis showed that the target of these compounds is involved in protein transport and protein localisation most likely relating to the vesicle tethering. Although many aspects of this work still need further investigation, either through the synthesis of new 1,2-cyclopropyl carbohydrates to increase bioactivity and better understand the enzymatic target, or through further biological procedures to better understand the mechanism of action, the use of 1,2-cyclopropyl carbohydrates as a potential pharmaceuticals or probes of protein trafficking shows much promise. 


\section{Acknowledgements}

I would like to start by acknowledging and thanking my family, for without you none of this would have even been possible. Mum and dad, thank you for all your support, emotionally and financially, which have allowed me to make the decisions that I have regarding my education. Your horrible dad jokes and loving care packages have not gone unnoticed. Yan and Inès, thank you for always being there for a chat and to distract from the stress of non-stop work. Yan, thanks for always being positive, supportive and an amazing friend as well as a brother.

My biggest thank you is to my supervisor AProf. Dr. Paul Teesdale-Spittle, thank you for all your help and patience, with my unrelenting cascade of questions and believing in me when I doubted my abilities. Your positivity and excitement toward both chemistry and biology always inspired me to want to better myself and learn new things. Dr. Joanne Harvey, my secondary supervisor, thank you for your endless energy, positivity and excitement which was definitely enough to keep me excited about chemistry even when everything seems to be going wrong.

To all the 'breathers' and 'ata gee' that I'm privileged to call my friends although the list is too long to name you know who you are. I hope the ridiculous yarns and the outlandish times continue for many years to come. A special thanks to Mike, Steve, Millie, Marcos, Harley and Kieran you 'ata gees' are mean as!

Thank you to all the members, past and present, of the organic synthesis research lab for all the help, suggestions and tips over the past two years. I would have definitely struggled without everyone's help. I've enjoyed working with you all especially when we jam out to Taylor Swift, for arguably far too long. Special thanks to Sarah for putting up with me for almost 6 years, I have absolutely no idea how you did it, amazing! I would also like to thank all the members of the chemical genetics lab, especially Namal, Richard and Bede for introducing me to the exciting and magical word of yeast. Without guys I would have had absolutely no idea what I was doing.

Finally thank you Kristiana for everything! Especially keeping me alive over the past 2 months by bringing me food and proofing all my work. You are amazing. 


\section{Table of contents}

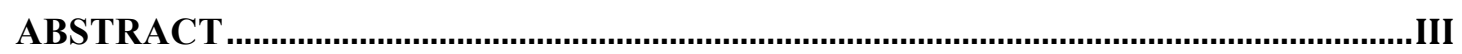

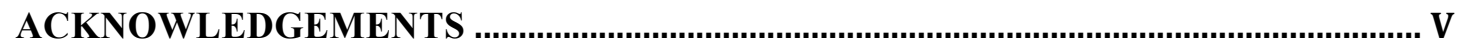

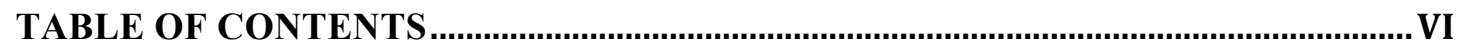

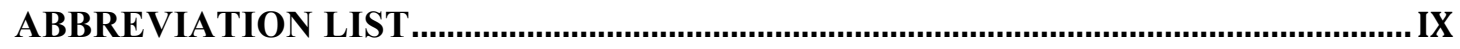

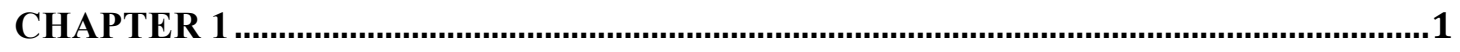

INTRODUCTION

1.1 HISTORY OF DRUG DISCOVERY .............................................................................. 1

1.2 APPROACHES TO DRUG DESIGN ........................................................................................ 2

1.2.1 Structure-based drug design ...................................................................................

1.2.2 Ligand-based drug design ............................................................................................

1.2.3 Mechanism-based drug design.............................................................................

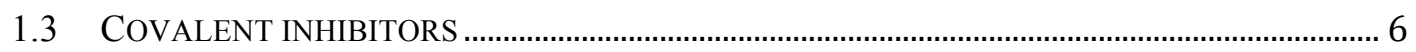

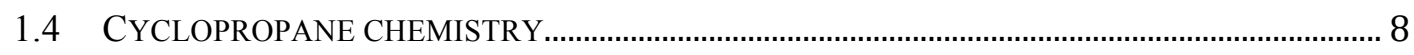

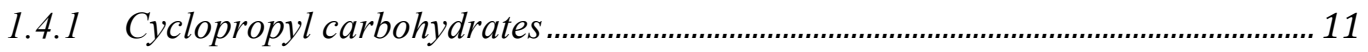

1.5 TARGET IDENTIFICATION AND MECHANISM OF ACTION ………………….....................14

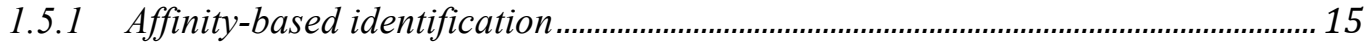

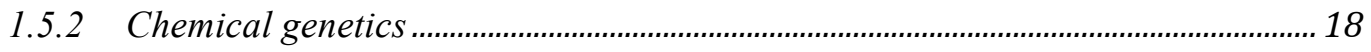

1.6 BASIS OF THIS RESEARCH PROJECT …………….......................................................19

1.7 RESEARCH HYPOTHESIS AND OBJECTIVES .......................................................................22

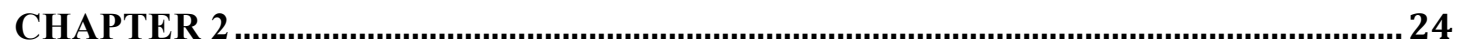

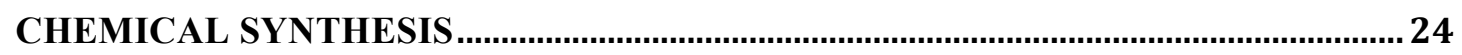

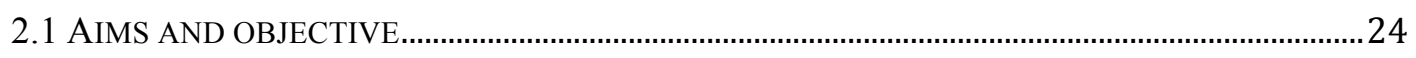

INTRODUCTION

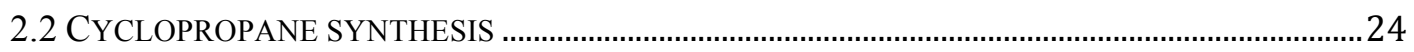

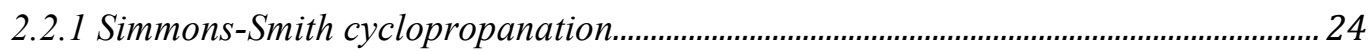

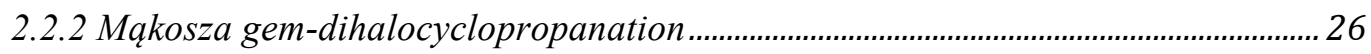

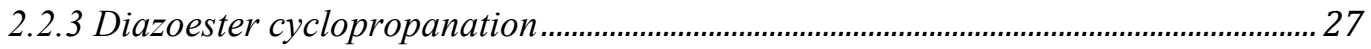

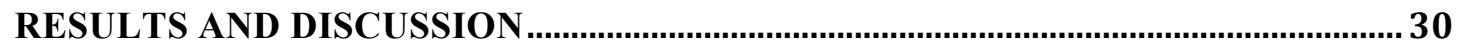

2.3 SYNTHESIS OF 1,5-ANHYDRO-3,4-DI- $O$-BENZYL-2-DEOXY-6- $O$-TRITYL-D-ARABINO-

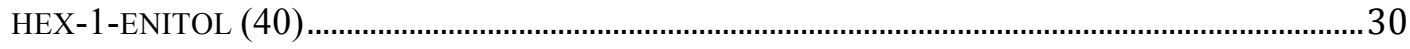


2.5 SYNTHESIS OF (( $(2 R, 3 S, 4 R)$-3,4-BIS(BENZYLOXY)-3,4-DIHYDRO-2H-PYRAN-2-

YL)METHOXY)(TERT-BUTYL)DIPHENYLSILANE (45) …….........................................................36

2.6 SYNTHESIS OF THE ETHOXYCARBONYL SUBSTITUTED 1,2-CYCLOPROPYL

CARBOHYDRATES 54 AND 55.

2.7 SYNTHESIS OF THE PROPARGYLOXYCARBONYL SUBSTITUTED 1,2-CYCLOPROPYL

CARBOHYDRATES 61 AND 62

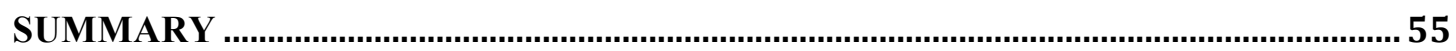

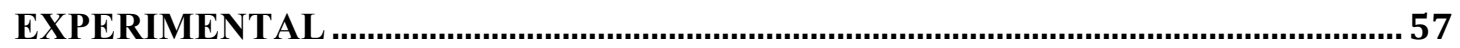

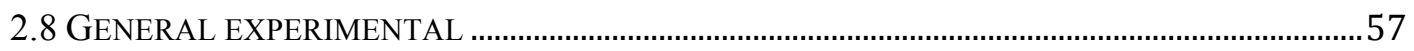

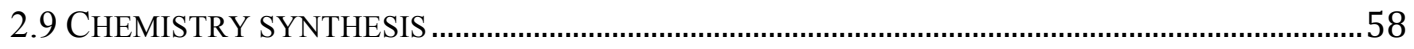

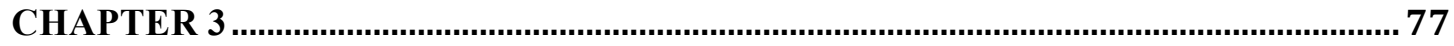

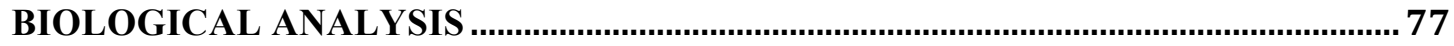

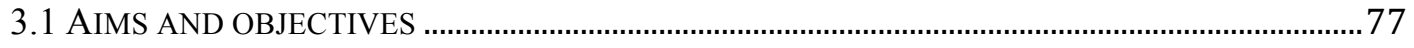

INTRODUCTION

3.2 YEAST AS A MODEL ORGANISM ………………………..........................................................

3.3 THE YEAST PDRI $\triangle P D R 3 \triangle X X X \triangle$ DELETION MUTANT ARRAY .................................................80

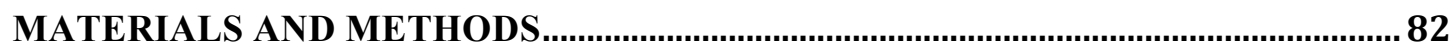

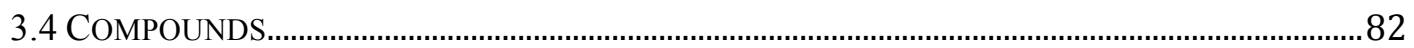

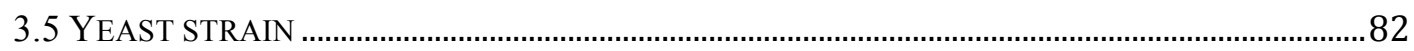

3.6 YEAST CULTURE AND GROWTH CONDITIONS ....................................................................... 82

3.6.1 Synthetic complete (SC) media................................................................................. 83

3.6.2 Synthetic drop-out (SD) minus URA media …………….......................................... 83

3.6.3 Yeast peptone dextrose (YPD) media ……………..................................................... 83

3.6.4 Amino acid mix for SC media ……………...................................................................... 84

3.7 DOSE-RESPONSE ASSAY IN SACCHAROMYCES CEREVISIAE …………………....................... 84

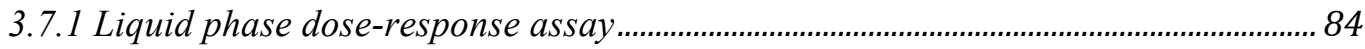

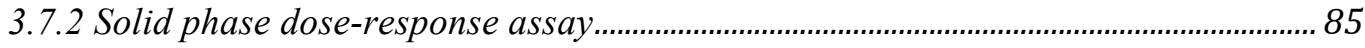

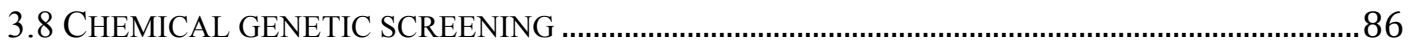

3.9 VALIDATION OF CHEMICAL GENETIC SCREENS …………....................................................8

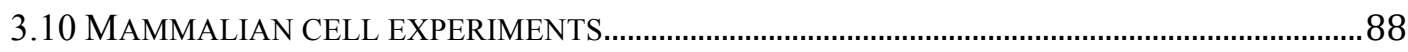

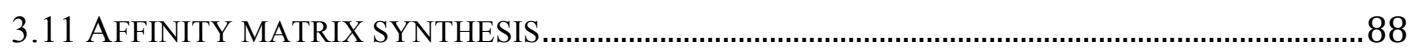

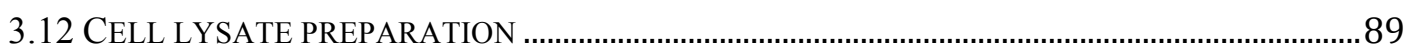

3.13 COPPER-ASSISTED AZIDE-ALKYNE CYCLOADDITION........................................................ 


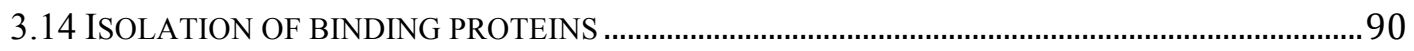

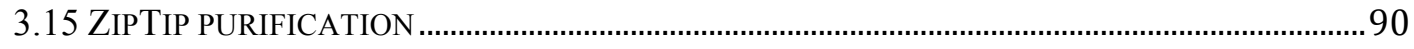

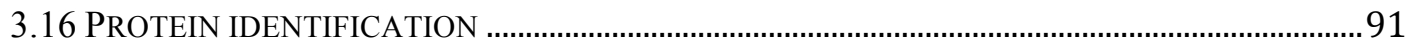

3.16.1 LTQ tandem mass spectroscopy ........................................................................... 91

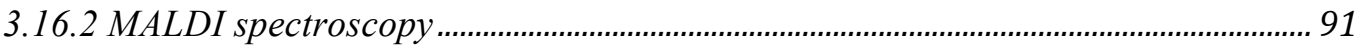

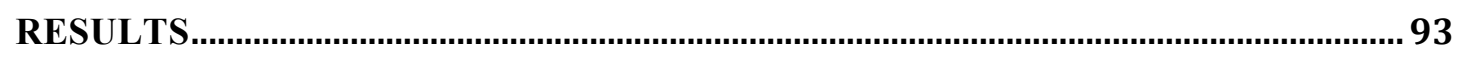

3.17 DOSE-RESPONSE ASSAY IN SACCHAROMYCES CEREVISIAE ……........................................ 93

3.17.1 Liquid phase dose-response assay ………….............................................................. 93

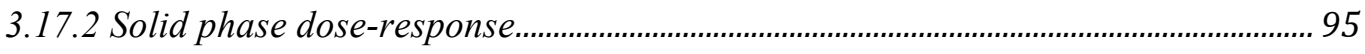

3.18 CHEMICAL GENETIC SCREENS......................................................................................96

3.19 VALIDATION OF CHEMICAL GENETIC HITS ………………………………………………....98

3.20 HYPOTHESIS TESTING OF NON-VALIDATED STRAINS ............................................................ 102

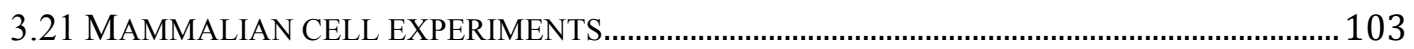

3.22 PROTEIN ISOLATION AND IDENTIFICATION VIA AFFINITY PURIFICATION.......................104

DISCUSSION

3.23 DOSE RESPONSE IN RELATION TO CHEMICAL STRUCTURE ……......................................106

3.24 CHEMICAL GENETIC ANALYSIS........................................................................................... 110

3.25 AFFINITY PURIFICATION OF TARGET PROTEIN................................................................. 117

SUMMARY

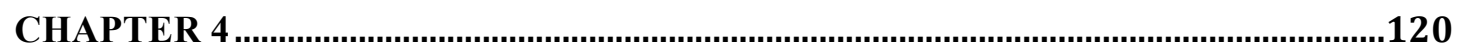

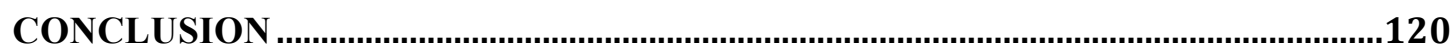

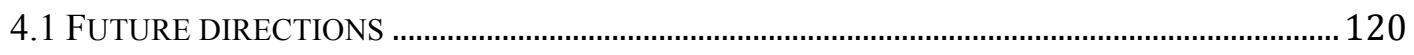

4.1.1 Structure-activity relationship.................................................................................120

4.1.2 Elucidation of the mechanism of action and target identification............................121

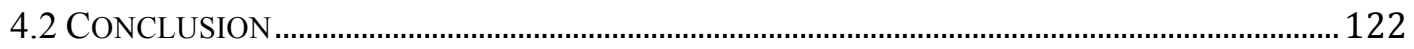

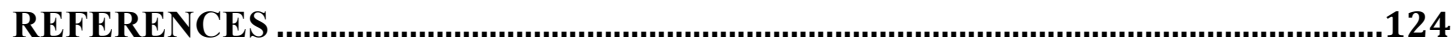

APPENDIX

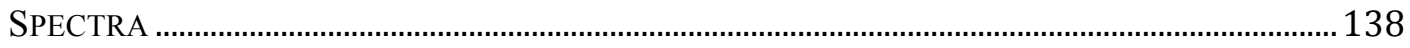

CHEMICAL GENETIC HITS................................................................................................ 158

Resistant Validations ..................................................................................................158

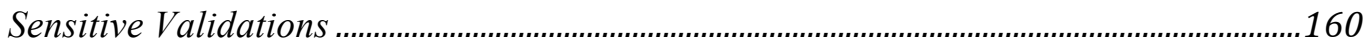




\begin{tabular}{|c|c|}
\hline \multicolumn{2}{|c|}{ Abbreviation list } \\
\hline${ }^{1} \mathrm{H}$ NMR & Proton nuclear magnetic resonance \\
\hline${ }^{13} \mathrm{C}$ NMR & Carbon13 nuclear magnetic resonance \\
\hline$\delta$ & Chemical shift (ppm) \\
\hline Ac & Acetyl \\
\hline $\mathrm{Bn}$ & Benzyl \\
\hline b.p. & Boiling point \\
\hline CHCA & Alpha-cyano-4-hydroxycinnamic acid \\
\hline COG & Conserved oligomeric golgi complex \\
\hline CID & Collision-induced dissociation \\
\hline CPD & Cyclopropane-1,1-dicarboxylate \\
\hline $\mathrm{d}$ & Doublet \\
\hline dd & Doublet of doublets \\
\hline ddd & Doublet of doublets of doublets \\
\hline DCM & Dichloromethane \\
\hline $\mathrm{dH}_{2} \mathrm{O}$ & Distilled water \\
\hline DHFR & Dihydrofolate reductase \\
\hline DMA & Deletion mutant array \\
\hline DMF & $N, N$-dimethylformamide \\
\hline eq & Equivalents \\
\hline FTMS & Fourier transform mass spectroscopy \\
\hline GARP & Golgi associated retrograding protein \\
\hline GFP & Green fluorescent protein \\
\hline GO & Gene ontology \\
\hline GSH & Glutathione \\
\hline HTS & High-throughput screening \\
\hline IR & Infrared \\
\hline IUPAC & International Union Of Pure And Applied Chemistry \\
\hline KARI & Ketol-acid reductoisomerase \\
\hline LDS & Lithium dodecyl sulfate \\
\hline LTQ & Liner ion trap \\
\hline $\mathrm{m}$ & Multiplet \\
\hline m.p. & Melting point \\
\hline
\end{tabular}




$\begin{array}{ll}\text { NMR } & \text { Nuclear magnetic resonance } \\ \text { NOE } & \text { Nuclear Overhauser effect } \\ \mathrm{Nu} & \text { Nucleophile } \\ \text { o/n } & \text { Overnight } \\ \text { ORFs } & \text { Open reading frames } \\ \text { Py } & \text { Pyridine } \\ \text { q } & \text { Quartet } \\ \text { QSAR } & \text { Quantitative structure relationship } \\ \text { r.t. } & \text { Room Temperature } \\ \text { s } & \text { Singlet } \\ \text { SAR } & \text { Structure-activity relationship } \\ \text { Sat. } & \text { Saturated } \\ \text { SDS } & \text { Sodium dodecyl sulfate } \\ \text { t } & \text { Triplet } \\ \text { TBAI } & \text { Tetrabutylammonium iodide } \\ \text { TBAF } & \text { Tetrabutylammonium fluoride } \\ \text { TBDMSCl } & \text { tert-butyldimethylsilyl chloride } \\ \text { TBDPSCl } & \text { tert-butyl(chloro)diphenylsilyl chloride } \\ \text { TEBAC } & \text { Triethylbenzylammonium chloride } \\ \text { TFA } & \text { Trifluoroacetic acid } \\ \text { TLC } & \text { Thin layer chromatography } \\ \text { Tr } & \text { Trityl } \\ \text { YGDS } & \text { Yeast genome deletion set } \\ \text { YDS } & \text { Yeast deletion set } \\ & \end{array}$




\section{Chapter 1}

\section{Introduction}

Carbohydrates and cyclopropanes have long been used in the field of pharmacology for their respective reactivity and structural properties. The high stereochemical information contained within carbohydrates and their ability to mimic the structure and function of naturally occurring compounds have made them powerful tools in drug design. Organic chemists have also utilised the ability of cyclopropanes to undergo ring-opening and ring-expansion reactions. ${ }^{3}$ These investigations have raised the question as to whether cyclopropyl carbohydrates can mimic natural compounds and undergo such reactions via enzymatic processes within cells, which could potentially lead to the discovery of a new covalent bioactive compound. ${ }^{2}$

This thesis aims to explore these ideas through the synthesis of a variety of potentially bioactive 1,2-cyclopropyl carbohydrate structures. A small library of compounds will be synthesised to undergo both yeast and mammalian cell assays where they will be screened for potential bioactivity. Bioactive compounds will then be subjected to both chemical and genetic techniques in order to identify the molecular target and elucidate their mechanism of action. This will be achieved through the synthesis of a molecular probe to bind any potential targets to an affinity purification resin and through chemical genetic analysis utilising activity screening against yeast deletion set.

\subsection{History of drug discovery}

The modern era of drug research and drug development as we know it dates back more than a century, when chemical concepts and principles were applied to problems outside the field of chemistry. This application began around the mid- $19^{\text {th }}$ century when the periodic table had been established and the atomic hypothesis proposed by Avogadro had been confirmed. ${ }^{4}$ The development of the modern field of chemotherapeutics coincided with the industrial revolution and the move from 
biofuels to coal and tar. The use of these new fuels created sizable quantities of byproducts that were found to contain large amounts of aromatic and aliphatic compounds. The discovery of the aromatic and aliphatic compounds and their use as dyes in the mid- $19^{\text {th }}$ century prompted chemist, Paul Ehrlich, to investigate their affinity with biological tissue. From his work, he postulated the existence of chemoreceptors, and that pathogens contained chemo-receptors with slight structural variation to our own, allowing therapeutic exploitation of these sites. ${ }^{4}$ This became the basis of medicinal chemistry and the birth of modern chemotherapeutics.

Comparatively, the use of plants as herbal medicine far outdates that of medicinal chemistry. The use of plants in traditional Chinese and North American medicine is an ancient practice that is still used currently. Additionally, the isolation and purification of the active compounds from traditional plant-based remedies have also played a role in the advancement of medicinal chemistry in the $19^{\text {th }}$ century. Morphine was first isolated from Papaver somniferum, a species of opium poppy plants, in 1815 by F. W. Sertürner. ${ }^{4,5}$ The discovery of morphine and its medicinal properties led to an increased pharmaceutical interest in the field of natural products, resulting in the discovery of many more natural bioactive products such as paclitaxel (Taxol), a commonly used anticancer drug. ${ }^{7}$ Later in the $20^{\text {th }}$ century, the accidental contamination of an agar plate containing Staphylococcus variants with a white fluffy mould led to the discovery of the natural product penicillin by Alexander Fleming which greatly influenced the field of medicinal chemistry. ${ }^{6}$ Penicillin was found to be a very effective antibiotic and quickly became the most widely used antibiotic due to its lack of toxicity and high efficacy. This led the way to a new era of antibiotics, with the majority of pharmaceutical companies establishing microbiology and fermentation departments in the hope of discovering similar natural products. ${ }^{4}$

\subsection{Approaches to drug design}

The processes of drug design have come a long way since the major findings of both Paul Ehrlich and Alexander Fleming. Several new approaches have been developed which are more systematic rather than serendipitous, although a certain element of serendipity still remains. These new approaches have been made possible due to the 
corresponding advancements made in many other aspects of biological, physical and chemical sciences. The most notable approaches to drug design can be split into three categories.

\subsubsection{Structure-based drug design}

As the name implies, structure-based drug design relies on the $3 \mathrm{D}$ structural knowledge of the biological target. This method of drug design had been very limited until the early 1990s when technological advancements were made in the fields of Xray crystallography, homology modelling and nuclear magnetic resonance (NMR) spectroscopy, providing methods to better determine the structure of the biological targets. ${ }^{8}$ In 1990, Roberts and colleagues ${ }^{9}$ released the first publication utilising structure-based drug design in the synthesis of small peptide-derived molecules that mimicked the protease activity of the human immunodeficiency virus (HIV). Once a biological target is found and its structure is elucidated, compounds and fragments in a computer data system are typically screened against the target in the search for the best fitting compound, which utilises as many non-covalent interactions as possible. Based on the steric and electronic effects, the compounds of best fit are then synthesised and tested against the target to determine their $\mathrm{IC}_{50}$ concentrations. The lead compounds are normally altered in attempts to heighten their potency by increasing the amount of interactions they can establish. ${ }^{10}$ Identifying a biological target can be the most difficult and lengthy process, as extensive research must be carried out to confirm that the target is involved in the pathophysiology of the disease. $^{10}$

\subsubsection{Ligand-based drug design}

The second method of drug design, ligand-based design, is most commonly employed when the 3D structure of the biological target remains unknown. Ligand-based drug design, also known as indirect drug design, relies on the structural knowledge of the compound that produces a desired pharmacological response. This allows for subsequent chemical modification of the lead compound, which will establish the 
pharmacophores necessary for the molecular recognition of both the active compound and the biological target. ${ }^{11}$ This is primarily achieved in two ways: structure-activity relationship (SAR) assays and quantitative structure-activity relationship (QSAR) assays.

SAR assays involve small chemical modifications of the lead compound in an attempt to better utilise the steric and electronic interactions within the biological binding site. This in turn can have both positive and negative effects on the affinity of the compound with the biological binding site. If the structural changes to the ligand cause undesirable steric and/or electronic effects, a decrease in binding affinity will result which will be marked by a reduced potency of the compound (higher $\mathrm{IC}_{50}$ ). The opposite is true for favourable steric and electronic interactions, leading to a higher binding affinity and in turn a lower $\mathrm{IC}_{50}{ }^{12}$ Knowing both the favourable and unfavourable interactions paints a picture of the shape and electronic effects within the binding pocket.

QSAR is similar to SAR assays, though it involves a computational method that finds a quantitative relationship between steric and electronic features of structurally related compounds and their biological activity. ${ }^{13}$ Pharmacophores are identified in a small library of molecules and correlations between the pharmacophores and the biological activity are calculated which then allow for the prediction of the bioactivity of untested compounds, inevitably directing future synthesis. However, for QSAR to be effective, a large amount of structural information is required on previously known molecules that activate the targeted binding site. ${ }^{12,14}$

\subsubsection{Mechanism-based drug design}

The term mechanism-based refers to the process of an enzyme catalysing its own inactivation. ${ }^{15}$ This typically occurs through an addition reaction, where an active nucleophilic residue located within the enzyme's binding site attacks an electrophilic centre on an inhibitor compound, ${ }^{16}$ forming a covalent bond. ${ }^{16,17,18}$ Mechanism-based drug design is therefore the design of a drug that will utilise the enzyme's catalytic mechanism to inactivate itself. ${ }^{19}$ Mechanism-based drug design can be approached in 
two manners: when the biological targets structure is known, much like structurebased drug design, or when the structural information about the target remains unknown.

The first approach is the synthesis of a covalently binding drug through prior structural knowledge of the target binding site, similar to structure-based drug design. For example, a study conducted by Vavricka and colleagues ${ }^{20}$ examined the possibilities of designing covalent inhibitors to target the influenza virus based on the knowledge of the active site of the viral neuraminidase (NA) enzyme. They found that the active site of the NA in influenza shared very few similarities with other organisms. Previous research indicated that a conserved tyrosine residue (Tyr406) within the NA active site could play an important role in the influenza NA mechanism. ${ }^{20}$ Using a fluorescence-based kinetic analysis of wild type influenza and Tyr406-deficient strains, Vavricka and colleagues showed a hundred-fold reduction in $\mathrm{k}_{\text {cat }}$ (catalytic constant of the conversion from a substrate to a product ${ }^{21}$ ) indicating that Tyr406 is essential for the catalytic activity in influenza NA. Based on this, they hypothesised that Tyr406 was acting as a catalytic nucleophile and would be able to initiate a nucleophilic attack of a covalent inhibitor. Using previous knowledge that influenza NA is a glycosidase, Vavricka and colleagues utilised structural and

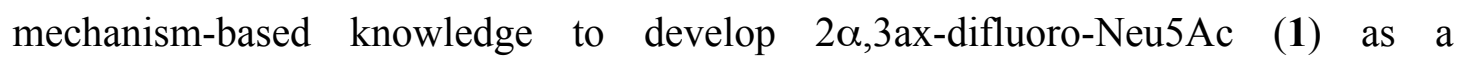
carbohydrate-derived covalent inhibitor of influenza NA as shown in scheme $1.1 .^{20} \mathrm{It}$ was envisaged that in order for $\mathbf{1}$ to undergo a nucleophilic attack at the anomeric carbon within the influenza NA enzyme, there needed to be several essential structural characteristics of the ligand. Firstly, a good leaving group is required at the C-2 position and a highly electronegative group at the C-3 position to prevent the formation of a potential oxocarbenium ion transition state. From the structural analysis of the binding pocket, it was also proposed that the leaving group should ideally be in the $\alpha$-position and therefore facing the outside of the binding pocket, allowing it to leave more readily. ${ }^{20}$ This led to a dramatic increase in potency of $\mathbf{1}$ compared to other influenza NA inhibitors. 


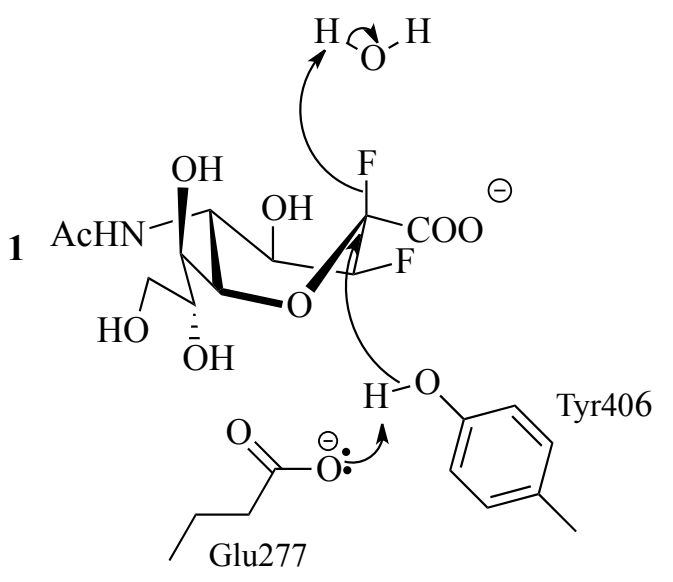

Scheme 1.1: Proposed mechanism-based inhibition of influenza NA through the covalent binding $\operatorname{drug} 1 .^{20}$

The second approach is not so well precedent. It involves prior knowledge of how the compound of interest would react when exposed to a nucleophile within an enzymatic-binding site. The expected reaction of the compounds are normally well understood within a chemically controlled environment. The question is then posed, whether it is possible to replicate these reactions within a cell through enzymatic activation, forming a covalent bond between the compound and the enzyme. ${ }^{2}$ This is a concept that will be explored throughout this thesis and covered furthered in section 1.4.1 Cyclopropyl carbohydrates.

\subsection{Covalent inhibitors}

Covalently binding drugs have long been exploited throughout medicine for many different uses, from analgesics to anti-cancer agents. ${ }^{22}$ Approximately $30 \%$ of drugs currently on the market act through covalent interactions with their target. ${ }^{22}$ However, more recently, the development of covalent drugs has declined due to the perceived lack of selectivity and off-target reactivity, which led to consequences such as hepatotoxicity and neurotoxicity. These fears arose from several studies undertaken in the 1970's and 80's, which reported that chemically inert drugs were metabolised to form reactive metabolites that covalently bound to a wide array of unrelated proteins 
in the liver. ${ }^{23}$ The key to overcoming this problem of non-selectivity is to alter the drugs' chemical and physical properties.

As shown in scheme 1.2, the formation of a covalent complex with the target molecule occurs in two steps. Firstly a non-covalent complex is formed involving non-covalent interactions such as hydrogen bonds, hydrophobic interactions and van der Waals forces. This reversible binding positions the ligand in the correct orientation within the binding site. This then allows for the second step to occur, which is the subsequent formation of the covalent bond via attack of the ligand by the enzyme.

$$
\begin{aligned}
& \mathrm{E}+\mathrm{I} \underset{\mathrm{K}_{\mathrm{i}}}{\rightleftharpoons} \mathrm{E} \cdot \mathrm{I} \underset{\mathrm{k}_{-2}}{\stackrel{\mathrm{k}_{2}}{\rightleftarrows--}} \mathrm{E}-\mathrm{I} \\
& \mathrm{E} \cdot \mathrm{I}=\text { Initial non-covalent complex } \\
& \mathrm{E}-\mathrm{I}=\text { Final covalent complex }
\end{aligned}
$$

Scheme 1.2: General mechanism for covalent binding drugs, E denotes enzyme and I denotes inhibitor.

The selectivity of a covalently binding drug can be greatly increased by altering both the covalent and the non-covalent interactions. A high affinity for the enzyme's binding site, which is indicated by a low dissociation constant, $\mathrm{K}_{\mathrm{i}}$, drives the formation of the non-covalent complex through utilisation of as many non-covalent interactions as possible. The increase in non-covalent interactions better positions the drug within the binding pocket, bringing the electrophile within close proximity of the nucleophile and increasing the residence time of the ligand within the binding pocket. This increased residence time in turn facilitates enzymatic nucleophilic attack. Increases in both the residence time and the amount of non-covalent interactions allow for reduced reactivity of the electrophilic covalent drug. The nucleophilic reaction then occurs due to the close proximity of the electrophile to the nucleophile rather than the presence of highly reactive moieties, thus reducing the chances of off- 
target binding and increasing the drugs selectivity. ${ }^{24}$ Therefore, selectivity is enhanced when the inherent reactivity of the covalent inhibitor is low, ensuring covalent attachment is highly dependent on the long lifetime of the E•I complex (scheme 1.2).

\subsection{Cyclopropane chemistry}

Cyclopropanes $\left(\mathrm{C}_{3} \mathrm{H}_{6}\right)$ are the smallest and simplest ring structures possible, consisting of only three carbon atoms. From the first reported synthesis of cyclopropanes in 1881 by August Freund, ${ }^{25}$ to their first commercial use as an anesthetic for dogs, ${ }^{26}$ thousands of cyclopropanated compounds have since been synthesised and discovered. Due to the interesting reactivity of the three-membered carbocycles, cyclopropyl moieties have become an important aspect in many pharmaceutical compounds. So much so that, as of April 2003, there were more than 200 patented pharmaceutical compounds containing cyclopropane functional groups in the literature. ${ }^{27}$ Cyclopropane-containing compounds have not only been found to have biological activity in humans but also in plants and microorganisms, interacting mainly with enzymes in enzyme-catalysed reactions.

Cyclopropane ring opening is a very important reaction in many active pharmaceutical agents. The physical and chemical properties of the cyclopropane ring greatly aid in its ability to undergo ring opening reactions. As shown in figure 1.0A, cyclopropanes contain bond angles of $60^{\circ}$, which is a substantial deviation from the preferred tetrahedral bond angle of approximately $109^{\circ}$. This decreased bond angle greatly increases the ring strain within the cyclopropane, increasing the cyclopropane's potential energy and providing the driving force of ring opening reactions. ${ }^{28}$ Additionally, the bonds within the molecule are bent. Although molecular orbital theory describes the cyclopropane's bonds as $\mathrm{sp}^{3}$-hybridised, drastic deviation away from the ideal tetrahedral angle results in bent bonds leading to an increased degree of $\mathrm{p}$ character $^{29}$ (figure 1.0B), and consequently increased reactivity. Cyclopropanes also have a high torsional strain due to the eclipsing interactions of vicinal substituents. The combination of both the high ring and torsional strain results in the ability of the cyclopropane to easily undergo ring opening reactions. 


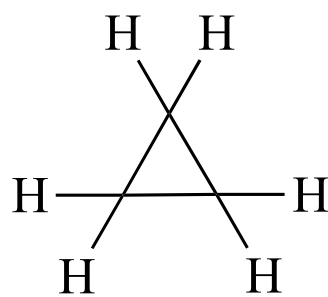

A

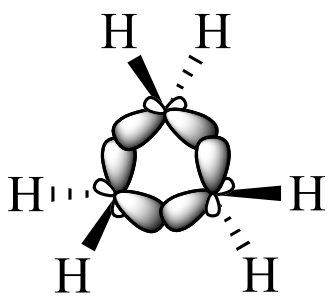

B

Figure 1.0: (A) Cyclopropane showing bond angle at $60^{\circ}$, (B) Molecular orbitals of cyclopropane showing bent bonds.

Cyclopropane moieties are often added as substituents to compounds, which due to their p-like characteristics provides an electrophilic centre, which can be subjected to nucleophilic attack resulting in ring opening or expansion reactions and the formation of a covalent bond. This can lead to irreversible attachment of the nucleophile to the original cyclopropane-containing compound.

Inhibition of dihydrofolate reductase (DHFR) by a pyrimidine (scheme 1.3) occurs in this manner. ${ }^{30}$ Through a combination of both structure-based and mechanism-based drug design, Haddow and colleagues ${ }^{30}$ proposed that the mechanism of action of DHFR occurred through a proton transfer from an aspartatic acid residue to dihydrofolate within the active site of the enzyme. From this, they hypothesised that the proton transfer from the aspartatic acid residue could activate a cyclopropyl substituent on pyrimidine (2) initiating a nucleophilic attack on the cyclopropane moieties from the enzymatic nucleophile. This in turn would cause a ring opening reaction to occur and, simultaneously, the formation of a covalent bond leading to the inhibition of the enzyme. ${ }^{30}$ This study showed the first mechanism-based approach to the development of DHFR inhibitors. ${ }^{30}$ 


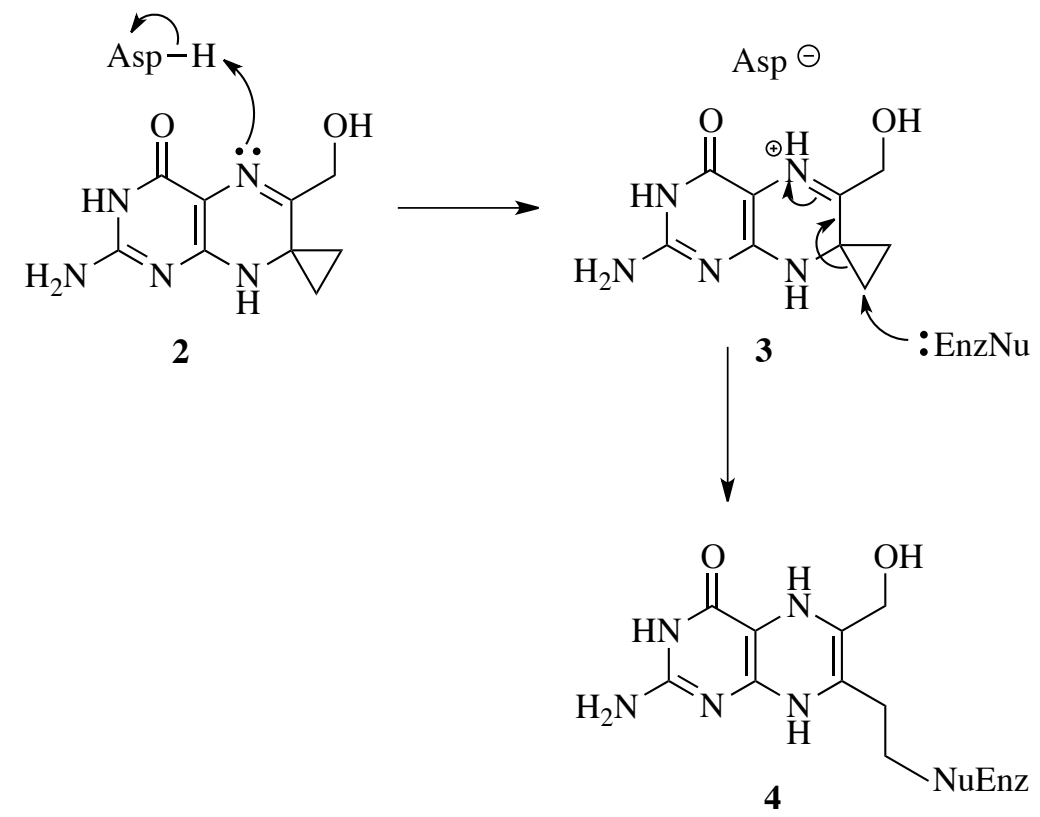

Scheme 1.3: Inhibition of DHFR via a ring-opening mechanism of a spirocyclopropane-containing pyrimidine. $^{30}$

However, not all bioactive cyclopropyl compounds go through either a ring-opening or ring-expansion reaction to have an effect. Cyclopropanes have been used to constitute novel rigidity to oligopeptide ligands in order to mimic peptide secondary structures, increasing their binding affinity for the enzymes active site, in attempts to outcompete the natural peptide. Although pseudopeptides are commonly designed to mimic the turns and helices of peptides, Martain and colleagues ${ }^{31}$ aimed to incorporate cyclopropanes into an oligopeptide in order to rigidify the structure into a locked $\beta$-strand conformation, which was known to be an essential characteristic for the activation of HIV-1 proteases (figure 1.1). Following the synthesis of compounds 6 and 7 it was reported that when the substituents on the cyclopropane were in the trans position, this caused locking of the $\Phi$ angle (angle corresponding to the $\mathrm{N}-\mathrm{C} \alpha$ on the unmodified peptide backbone 5) at approximately $-120^{\circ}$ resulting in the locked $\beta$ strand conformation. Although the conformation of $\mathbf{6}$ was only determined in solution it was reported as almost identical to the conformation of 7 of which Martain and colleagues $^{31}$ were able to get an X-ray crystal structure of the ligand (7) within the HIV-1 protease binding site. This indicated that the preferred structural conformation 
of these compounds in solution closely matches that of the conformation needed in the enzyme's active site. ${ }^{32}$ Both compounds 6 and 7 were found to be bioactive in the low nanomolar range, indicating potent inhibition of the HIV-1 protease. Therefore, Martain and colleagues ${ }^{31}$ results show compelling evidence that the trans-substituted cyclopropanes introduced into the oliopeptide are able to rigidify the structure locking it into a $\beta$-strand conformation.<smiles>[R]CC(N[R])C(=O)NC(C[R])C(=O)N[R]</smiles>

5

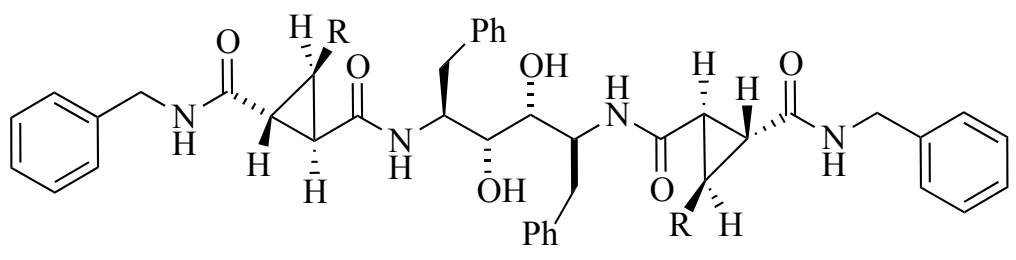

6: $\mathrm{R}=\mathrm{Me}$

7: $\mathrm{R}=\mathrm{H}$

Figure 1.1: Trans substituents on the cyclopropane provide structural rigidity locking $\mathbf{6}$ and $\mathbf{7}$ into a locked $\beta$-strand conformation.

\subsubsection{Cyclopropyl carbohydrates}

Carbohydrates are polyhydroxylated compounds with numerous chiral centres, which have made them an area of great interest in organic chemistry, with the synthesis of novel carbohydrate derivatives being used in different scientific disciplines such as glycobiology, glycomics and chemical synthesis. Cyclopropanes are commonly incorporated into carbohydrates through their installment at the 1,2-position of the sugar. The synthesis of 1,2-cyclopropyl carbohydrates commonly results from the addition of a carbene to a glucal. Though several protected glucals are commercially available, it is also possible to synthesise them from their corresponding parent sugars. The combination of both cyclopropanes and carbohydrates provides an 
interesting area of research, with the chemical and physical properties of cyclopropanes such as ring and torsional strain as well as the numerous chiral centres of carbohydrate molecules. For example, a lot of research has been done around pyranoside-based cyclopropanes in ring expansion reactions to form seven-membered oxepines (schemes 1.5 and 1.6)..$^{33,34,35}$

Ring opening reactions of 1,2-cyclopropanated pyranose sugars have been demonstrated to form 2-C-branched pyranosides ${ }^{34,36}$ with the proposed mechanism involving the selective nucleophilic addition at the anomeric position resulting in the formation of a carbanion, which is stabilised by the electron-withdrawing substituent on $\mathrm{C}-7$ (scheme 1.4). Under basic conditions, C-2 deprotonation occurs, causing the loss of a C-7 substituent formation of the 2-C-branched pyranoside. However, this mechanism has only been shown to occur in the presence of electron-withdrawing substituents on the cyclopropane. ${ }^{3,35}$

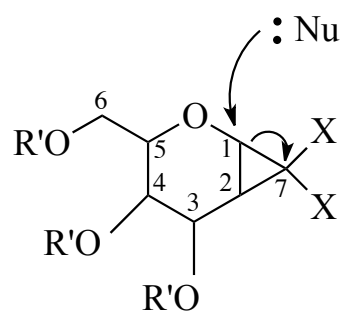

14<smiles>[X]C=C1C([NH])=C(CO[R20])C([R])C1[R20]</smiles>

18<smiles>[R20]CC1OC(N)=C(C([X])[X])C([R])C1O[R20]</smiles>

15

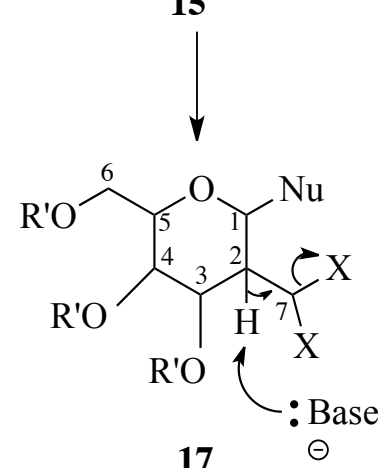

Scheme 1.4: A plausible mechanism for ring opening forming C-2-branched pyranosides. 
Formation of oxepines can occur through two different pathways as shown in schemes 1.5 and 1.6. Ring expansion to form the oxepine readily occurs in the presence of a nucleophile under basic conditions or in the presence of a Lewis acid. ${ }^{2}$ 34 Nucleophilic attack at the C-1 position, promoted by a Lewis acid or an electrophile, can result in the ejection of the substituent on either the C-7 position (scheme 1.5) or the C-3 position (scheme 1.6) depending on which position has the superior leaving group. Under the correct conditions, ring opening or expansion (schemes 1.4, 1.5 and 1.6) of 1,2-cyclopropanated sugars have characteristics susceptible to catalysis by enzymes. The enzyme would require a nucleophilic moiety and a correct spatial configuration in its binding site to accommodate the cyclopropanated sugar, along with the ability to stabilise a transition state during the subsequent reaction. Given theses properties, nucleophilic attack on the cyclopropanated sugar could lead to the formation of a covalent bond resulting in irreversible binding. Depending on the target this might then result in biological activity, which is the starting process of mechanism-based drug design.<smiles>[R20]CC1OC2(CC=N)C([R])C([R])C1C2([X])C[R]</smiles>

19<smiles>[R20]CC1OC([NH])=C([X])C=C([R20])C1[R20]</smiles>

20

Scheme 1.5: A proposed mechanism for ring expansion through loss of a C-7 leaving group.

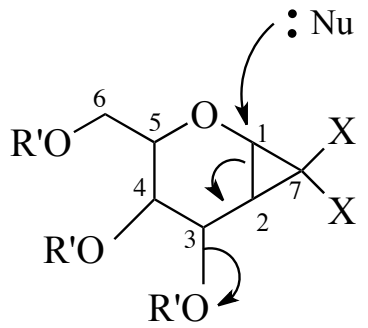

21

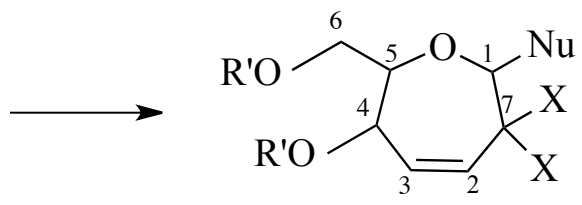

22 


\subsection{Target identification and mechanism of action}

The identification of drug targets have been made possible due to the vast advancements made in the research field. To this end, methods for identifying molecular targets can be roughly split into three groups: computational approaches, genetic-based approaches and biochemical approaches. Computational approaches are used to predict drug targets based on the chemical similarities of known inhibitors; genetic-based approaches utilise gene deletion and over-expression sets as a tool to determine pathways, which the compound may act upon; ${ }^{37}$ and biochemical approaches employ chemical proteomics and affinity purification methods for target identification.

Before target identification can occur, however, the discovery of small bioactive compounds that are able to elicit a desired response either against a cell or organism is required. Whilst cytotoxicity is often perceived as an end-point, addressing the phenotypic response can be carried out through two processes, namely reverse chemical genetics or forward chemical genetics screening, respectively. ${ }^{38,39,40,41}$

Developments made in the fields of biochemistry and molecular biology makes screening a library of compounds against specifically selected proteins a readily accessible method for identifying new bioactive small molecules. This is known as reverse chemical genetics or target-based screening. The specifically selected proteins are normally involved in the pathophysiology of diseases such as G-protein coupled receptors and kinases. However, target selection and validation can be timeconsuming processes. Selection of the target is based on its therapeutic potential and its accessibility in a high-throughput screen (HTS). ${ }^{41}$ When the biochemical target is identified, it must first be validated, typically through molecular biological approaches. Once validated, a library of small molecules is then screened to identify functional ligands that are able to induce or suppress the target's activity. When a small bioactive molecule is identified, it is then introduced into a cell or organism in attempts to study its mechanism of action. ${ }^{38}$ However, although reverse chemical genetics may result in the identification of a highly specific bioactive small molecule, targeting a specific protein may prevent identification of potential off-target effects 
that can arise in more complex systems as well as the activation of multiple signalling pathways. ${ }^{42}$ Additionally, targeting a specific protein involved in the pathophysiology of disease can ultimately impede the progress of drug development and discovery as it does not lead to the identification of new targets. ${ }^{40}$

On the other hand, forward chemical genetic screening, also known as phenotypebased screening, screens small molecules against whole cells, allowing for the identification of potential new and unexpected targets and multiple signalling pathways, unlike reverse chemical genetics, which screen against a single isolated protein. This process has become possible due to the recent advances made in assay technology and involves the direct screening of small molecules to evaluate their effects on biological processes. ${ }^{41}$ The budding yeast Saccharomyces cerevisiae is a commonly used organism in phenotype-based screening due to its extensively studied genetics, rapid doubling time and easy maintenance, making it an ideal organism for HTS. Yeasts are screened against a library of small molecules in an attempt to induce a phenotypic change of interest. If the targeted phenotypic change occurs, the bioactive molecule will be selected for further investigation. This process allows for the rapid identification of bioactive compounds.

The development and use of forward chemical genetic screening has proved of great importance, with 28 of 75 first-in-class drugs being approved between $1999-2008$ resulting directly from phenotype-based screening compared to only 17 having been developed from target-based screens. ${ }^{39}$ Although forward chemical genetics allows for the potential discovery of new therapeutic targets, the elucidation of the molecular target remains one of the greatest limitations and challenges of forward chemical genetics. To this end, chemical proteomics methods such as affinity chromatography and chemical genetic analysis can be undertaken to identify the molecular target. ${ }^{43}$

\subsubsection{Affinity-based identification}

Affinity purification to identify bioactive small molecules and their targets has proved to be the most direct method for target identification in which whole cell extracts are passed through the affinity matrices and a protein target are isolated. ${ }^{44}$ For example, 
the identification of calcineurin as a common target for both immunosuppressant's FK506 and cyclosporin $\mathrm{A}^{39,38,45}$ was achieved by subjecting a whole cell lysate to a FK506 and cyclospoirn A affi-gel 10 affinity matrix. Affinity purification is considered to be the oldest, yet most commonly used method for target identification. $^{46}$

Affinity purification is commonly achieved through one of two methods. The first method involves the incorporation of an affinity tag such as a fluorescent chromophore to the bioactive molecule, whereas the second method typically requires a chemical modification of the compound so it can be immobilised onto a resin. Resins such as agarose are commonly employed, and the bioactive compounds are attached via a spacing linker group. Ideally, the linker group should be long enough to prevent steric interactions between the resin and the target protein and be mildly hydrophobic therefore preventing auto-aggregation. ${ }^{38,46}$ A reactive terminal on the linker allows it to undergo the appropriate coupling reaction to an appropriate functional group of the bioactive compound (figure 1.2). Alternatively, the bioactive compound can be conjugated onto moieties such as biotin, which interact strongly with avidin, resulting in a high affinity loading of the bioactive compound onto avidin agarose resin. ${ }^{38,39}$

However, the modification of bioactive small molecules must be carried out carefully in order to avoid a reduction in the bioactivity. To this end, it is essential that, after derivatisation of the bioactive molecule, it retains its target-recognising properties. This requires some prior knowledge of the interaction with the target, which can be established through SAR assays. The resulting analogue must then be re-evaluated to ensure that biological activity or target affinity is retained. ${ }^{47}$ 

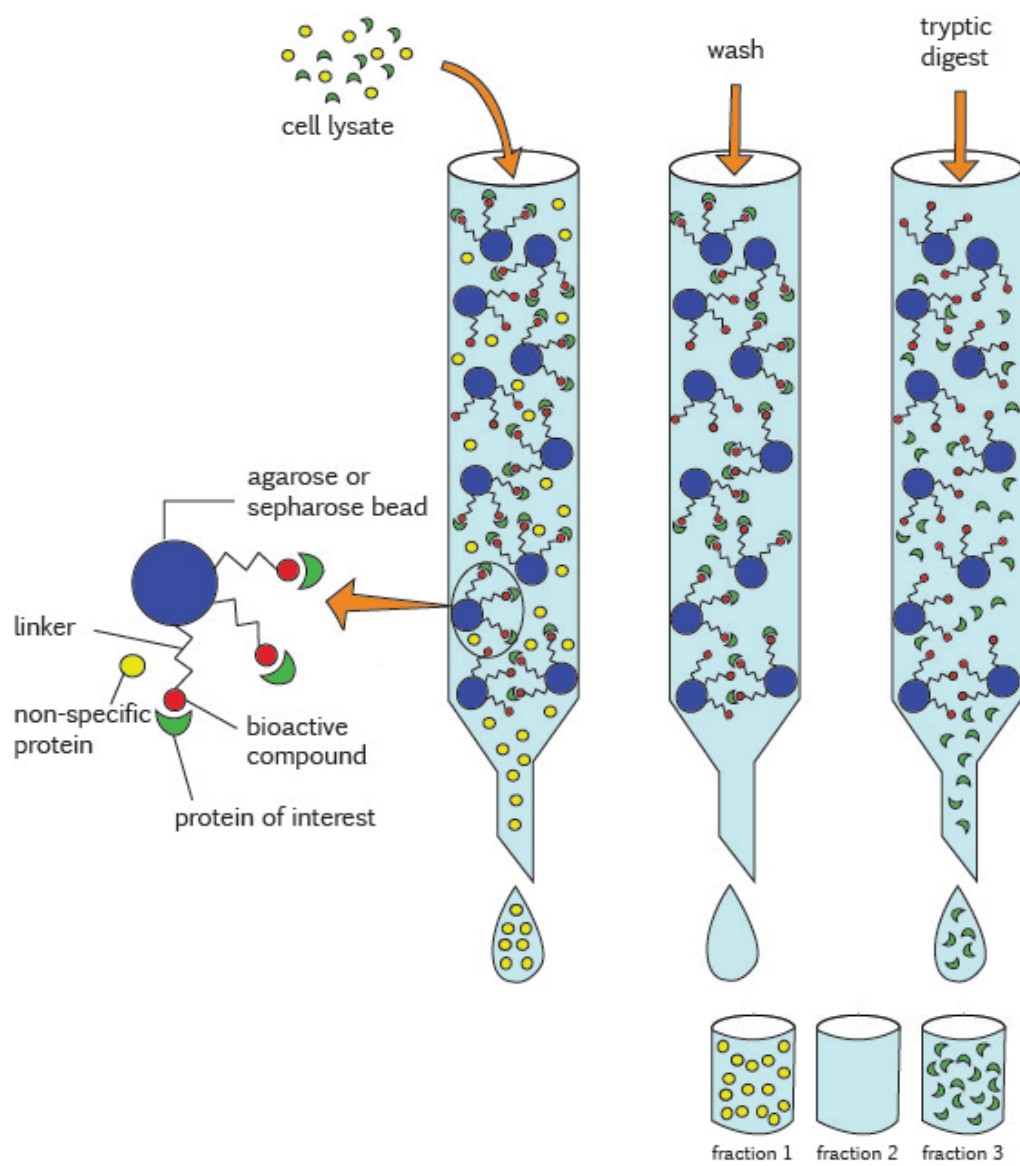

Figure 1.2: Linker groups attached to agarose or sepharose allow for the attachment of chemically modified bioactive compound. Cell lysate interact with the bioactive compounds allowing for interaction with the target protein. Non-specific proteins are eluded and treatment of the agarose/sepharose matrix with tryptic digest allows isolation of the specific binding proteins.

Following the installment of the bioactive compound to an affinity resin, it is then exposed to its target protein. This is done by passing either whole cell lysates or protein extracts through a column containing the immobilised compound, a process known as affinity pull-down (figure 1.2). ${ }^{41,39}$ This must be done under suitable conditions, as salts and detergents used in the cell lysate process can affect the targetcompound interaction. This is normally followed by a series of washes to remove any non-specifically bound proteins. Finally, the tightly bound specific target proteins are removed using a wash or tryptic digest which hydrolyses proteins into peptides that can then be identified by process such as mass spectrometry. ${ }^{48,47,49,42}$ 


\subsubsection{Chemical genetics}

The process of target identification via genetics or genomic methods relies on the principle of genetic interacting pathways. ${ }^{41}$ This is most commonly done by the mutation of yeast genomes through deletion or over-expression of desired genes. The yeast genome was the first eukaryotic genome to be fully sequenced. It consists of 16 chromosomes, with approximately 6400 open reading frames (ORFs), of which approximately 4800 genes are non-essential such that deletion of the gene does not affect the viability of the yeast under standard laboratory conditions. Antibioticresistant markers and a synthetic barcode sequence have been integrated individually into the 4800 non-essential genes, allowing for the formation of yeast genome deletion sets (YGDS). ${ }^{50,37,51}$ Small bioactive molecules used in combination with YGDS can be used to help better understand gene activity. This is done through a process much like synthetic lethality. Synthetic lethality occurs when mutations of two non-essential genes lead to cell death, indicating the two pathways have the same essential end point. ${ }^{52}$ Chemical genetic analysis, however, requires the use of small inhibitory molecules to act as the 'second mutation' as shown in figure 1.3. HTS of a YGDS allows for the investigation of these interactions, as the small bioactive molecules act as modulators of gene activity. This high-throughput process is known as a deletion mutant array (DMA). ${ }^{51}$ Yeast that become non-viable or show a reduced viability will give insight to pathways and targets that are potentially involved in the bioactivity of the compounds.

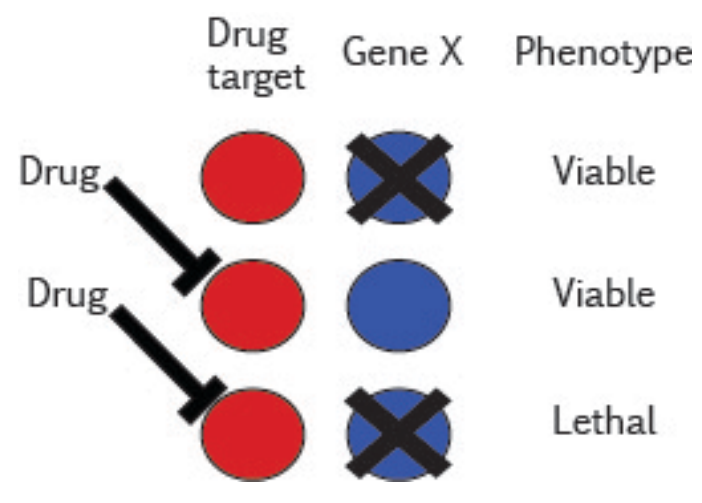

Figure 1.3: Chemical genetic approach to identifying drug pathways and interactions. Demonstrating the concept of chemical genetics, showing that cells are not viable with inhibition of the drug target and deletion of the identifiable gene. 


\subsection{Basis of this research project}

Initial interest began in mechanistic studies during the development of an effective synthetic route for the formation of oxepines. The inclusion of oxepines in numerous natural products and heptanoses presented these molecules as challenging synthetic targets. To this end, 1,2-cyclopropyl carbohydrates were chosen as substrates for the formation of oxepines through a cyclopropyl ring opening reaction and subsequent elimination of the C-3 substituent (scheme 1.5). ${ }^{33}$ However, later research by Harvey and colleagues utilising 1,2-dibromocyclopropyl carbohydrate for the investigation of synthetic routes to oxepines dervatives, noticed an unexpected ring opening reaction and elimination of the C-7 substituent which took place, leading to the unexpected synthesis of 2-C-branched pyranosides (scheme 1.4). ${ }^{34}$ These unusual and unexpected ring opening and expansion reactions were further examined in a mechanistic study. ${ }^{53}$ Once these mechanisms were better understood, the question was posed whether ring opening and ring expansion reactions of 1,2-cyclopropyl carbohydrates could be enzymatically catalysed and, if so, might lead to a mechanism-based inhibition reaction.

An initial project exploring the use of cyclopropanated glucals as covalent inhibitors was conducted by Dylan Davies at Victoria University of Wellington. ${ }^{2} \mathrm{He}$ hypothesised that cyclopropanated sugars could undergo enzymatic ring opening or ring expansion reactions resulting in formation of a covalent bond between the cyclopropanated sugars and its target. Should the synthesised cyclopropanated glucals bind covalently to a target it was suggested that this would occur through one of the three mechanisms discussed in section 1.4.1 and shown in schemes 1.4, 1.5 and 1.6.

He synthesised a compound library of 27 glucals with varying substituents at the carbon positions 1-7 (numbering shown in figure 1.4). Of the 27 compounds synthesised, 20 contained a cyclopropane, 12 contained chlorine at the $\mathrm{R}_{4}$ and/or $\mathrm{R}_{5}$ position while six contained bromine at the same positions. Substituents in the $\mathrm{R}_{1}, \mathrm{R}_{2}$ and $\mathrm{R}_{3}$ position included benzyl, acetyl, trityl, formyl as well as hydroxyl groups. The 27 compounds were subjected to a high-throughput SAR assay to identify the most bioactive compounds in S. cerevisiae. The SAR assay was run against the yeast strain $p d r 1 \Delta p d r 3 \Delta$ (drug efflux pump knockout strain). Of the 27 compounds subjected to 
this yeast strain, five were active, with only one also showing activity against the BY4741 wild-type strain. Structural similarities between the five bioactive compounds allowed for the postulation of the essential pharmacophore elements for this series of compounds.<smiles>[R10]C[C@H]1OC=C[C@@H]([R16])[C@H]1[R20]</smiles>

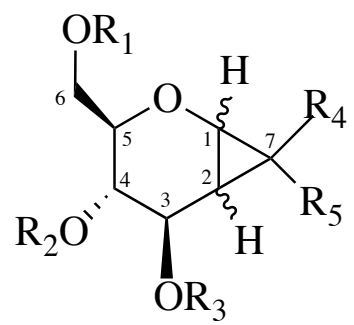

Figure 1.4: IUPAC numbering of carbons on both glucals and cyclopropanated carbohydrates.

The SAR study indicated that the presence of a benzyl group on the $R_{2}$ and $R_{3}$ positions was essential to the bioactivity of the compound. Lack of this benzyl group resulted in inactivity of the compounds. This indicated that nucleophilic attack of the $\mathrm{C}-1$ carbon, resulting in ring expansion and loss of the C-3 substituent as shown in scheme 1.4 (section 1.4.1), was and unlikely mechanism for the bioactive compound synthesised by Davies as the benzyl group is a poor leaving group.

It was also noted from the SAR results that the compounds containing chloride at the $\mathrm{R}_{4}$ and $\mathrm{R}_{5}$ positions resulted a higher bioactivity. As bromine is a substantially better leaving group than chlorine, this greater activity of the chlorine-containing products was proposed to be due to the increased ability of chlorine to stabilise an adjacent negative charge due to its increased electronegativity. Bickelhaupt and colleagues ${ }^{54}$ computationally showed that $\alpha$-stabilisation of a carbanion by $\mathrm{CH}_{2} \mathrm{X}$ is favoured by fluorine and progressively decreases for halogens of lower electronegativity. Therefore this would suggest that the formation of a covalent bond between the cyclopropanated glucals and the target was most likely to proceed by ring opening due to nucleophilic attack at the $\mathrm{C}-1$ position resulting in the formation of a carbanion at the C-7 position as shown in scheme 1.5 (section 1.4.1). This negative charge will then be better stabilised due to the electron-withdrawing effects of the chlorine atoms. 
This hypothesis will be further explored in this thesis by synthesising compounds with the ability to better stabilise a carbanion. Of the compounds synthesised by Dylan Davies, $\mathbf{2 3}$ was found to be the most active, shown in figure 1.5.

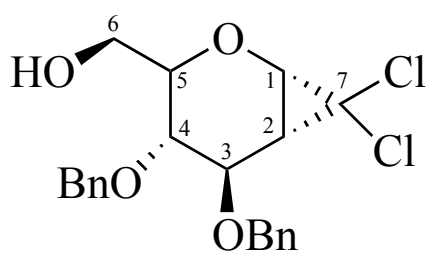

23

Figure 1.5: Chemical structure of 1,5-anhydro-3,4-di-O-benzyl-1,2-C-(dichloromethylene)-D-glyceroD-gulo-hexitol and carbon numbering according to IUPAC.

Davies synthesised a derivative of $\mathbf{2 3}$ to act as a molecular probe in order to ascertain whether the target protein could be identified using chemical proteomic affinity purification. This was attempted via the addition of two $p$-azidobenzyl protecting groups at the $R_{2}$ and $R_{3}$ position with the intention of the azide moiety undergoing a copper-assisted azide-alkyne cycloaddition with an alkyne-substituted sepharose matrix. However, although he was successful in adhering this derivative to the column matrix, no target was obtained and later analysis indicated bioactivity of this product was lost. This result reconfirms the necessity for benzyl groups at the C-3 and C-4 position.

Due to lack of target identification in the affinity purification, deletion set chemical genomic analysis was conducted ${ }^{2}$ in an attempt to identify a mode of action. However although a number of sensitive mutants were identified to $\mathbf{2 3}$, no enrichment through gene ontology (GO) analysis was found. Unusually, there were more deletion mutants that were resistant to the active compound than were sensitive. These resistant strains contained a higher percentage of genes involved in ribosomal translation. Therefore Davies hypothesised that $\mathbf{2 3}$ may affect a process that is involved in translation, processing of ribosomal subunits, or protein folding although the exact biological process remains unknown. 


\subsection{Research hypothesis and objectives}

This thesis will further explore principles discussed in the thesis of Dylan Davies and extend his work done on 1,2-cyclopropyl carbohydrates. ${ }^{2}$ It will be divided into two sections, an organic synthesis-based section and a biology-based section. Initial aims of this research will explore the hypothesis that ring opening occurs through nucleophilic attack at the $\mathrm{C}-1$ carbon, leading to the formation of a carbanion. This will be achieved by the synthesis of $\mathbf{2 3}$ and variants that contains a carboxyalkyl group at the C-7 position of the cyclopropanated carbohydrate (24) instead of the chlorines (figure 1.6). We have hypothesised that the carbonyl will allow for resonance stabilization through the formation of an enolate, providing carbanion stabilisation. ${ }^{55}$ The synthesised compounds will then be subjected to a bioactivity assay to see if bioactivity against $S$. cerevisiae is retained.

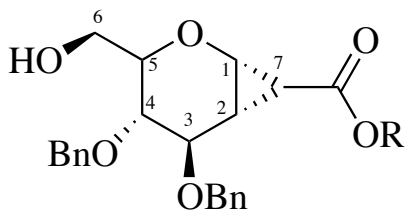

$24 \mathbf{a}=\widehat{\Upsilon}$

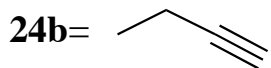

24

Figure 1.6: The proposed structure for a new lead compound, 1,5-anhydro-3,4-di- $O$-benzyl-2-deoxy1,2-C-(exo-carbmethoxymethylene)-D-glycero-D-gulo-hexitol

The second aspect of this thesis will attempt to identify a mechanism of action and molecular target of 24a and derivatives if they prove to be bioactive. Chemical genetic analysis using a $p d r 1 \Delta p d r 3 \Delta x x x \Delta$ yeast deletion set library on all bioactive derivatives will be conducted in an attempt to identify a mechanism of action through enrichment via gene ontology. This deletion library contains systematic gene deletion mutants (denoted $\mathrm{xxx} \Delta$ ) in a genetic background, which includes deletion of PDR1 and PDR3 genes, both of which encode transcription factors for the pleiotropic drug resistance-related drug efflux pumps. Resistant and sensitive strains will be validated to ensure no false positives. 
As previous attempts to isolate a molecular target were unsuccessful through the addition of a molecular probe at the C-3 and C-4 position, our aim is to modify the carboxyl group via the addition of a propargyl group. If bioactivity is retained, cell lysate will be subjected to the compound and a subsequent affinity pull down by a copper-assisted Huisgen azide-alkyne cycloaddition. ${ }^{56,57}$ Any isolated protein will be identified via mass spectrometry.

However, if $\mathbf{2 4}$ and its derivatives do not prove to be bioactive, further chemical genetic screening with $\mathbf{2 3}$ will be done in order to better identify the mode of action of the dichlorocyclopropane. This will include the use of yeast-based deletion and gene over-expression sets as well as fluorescent protein strains not used in the earlier study by Dylan Davies.

The main objectives of this research will begin with the initial aim to reproduce work done by Davies ${ }^{2}$ in attempts to optimise his synthesis of $\mathbf{2 3}$ and produce a true biological replicate. This will be followed by the synthesis of carboxyalkyl derivatives 24. Synthesised compounds will then need to undergo a bioactivity assay to assess whether they have retained bioactivity. Bioactivity assays will be conducted on $p d r 1 \Delta p d r 3 \Delta h i s 3 \Delta$ yeast in liquid media. If bioactivity is retained within the new set of synthesised compounds, modification of the ester to incorporate a linker group (24b), allowing for, a chemical proteomic affinity pull-down therefore isolation of the molecular target will be undertaken. If a molecular target is isolated, analysis of the target will be conducted through mass spectrometry. Chemical genetic analysis using the $p d r 1 \Delta p d r 3 \Delta x x x \Delta$ yeast deletion set library will then be conducted on the lead compound and results compares to the chemical genetic screen of $\mathbf{2 3}$, in attempt to identify a mechanism of action and enrichment through GO. Analysis will look at both resistant and sensitive strains. 


\section{Chapter 2}

\section{Chemical synthesis}

\subsection{Aims and objective}

Aims follow those presented in chapter 1. The aims of the work presented in this chapter are to synthesise target compound $\mathbf{2 3}$, as well as the potential exploration of new C-6 protecting groups on this scaffold. This will be followed by the synthesis of 1,2-cyclopropyl carboxyalkyl derivatives 54 (ethyl) and 61 (propargyl).

\section{Introduction}

\subsection{Cyclopropane synthesis}

Since Simmons and Smith first reported their synthetic procedure for the preparation of cyclopropanes in $1959,{ }^{58}$ many new approaches have since been developed. The basis of the reactions, however, which is the addition of a carbene or carbene-like reagent across an alkene, remains the same. ${ }^{59}$ Although reaction conditions have been expanded to use a range of different reagents, such as sulfur ylides, ethyl trichloroacetate, sodium trichloroacetates and methyl azides, ${ }^{60}$ the focus of this chapter will be on the more common Simmons-Smith, Mąkosza and diazocyclopropanation methodologies. ${ }^{60,61,62}$

\subsubsection{Simmons-Smith cyclopropanation}

Although the methodology for cyclopropane synthesis had already been established, Simmons and Smith reported the first cyclopropanation reaction that was stereoselective, high yielding and free of any unusual side reactions leading to unwanted by-products. $^{63,3}$ The synthesis consists of the addition of an alkene to diiodomethane and a zinc-copper couple. Although the exact mechanism of the reaction remains unknown, experimental evidence showed the formation of an 
organozinc transition state (26), namely iodomethylzinc iodide, which can promote a methylene transfer through $\pi$-donation from the alkene, leading to subsequent ejection of zinc iodide and formation of the cyclopropane (scheme 2.1A). ${ }^{58,64,63,62}$ Despite the known formation of transition state 26, however, controversy around the exact mechanism still remains. The high stereoselectivity of the Simmons-Smith cyclopropanation system bearing an allylic oxygen atom is said to be due to the coordination of the zinc to the oxygen-containing substituents, such as a hydroxyl or ether group, proximal to the alkene resulting in the syn-product (scheme 2.1B). ${ }^{62,61}$ This has been shown to give diastereoselectivities in excess of 250:1. ${ }^{61}$

A)

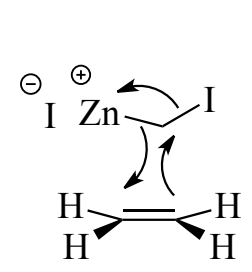

25<smiles>CC(C)(C)C</smiles>

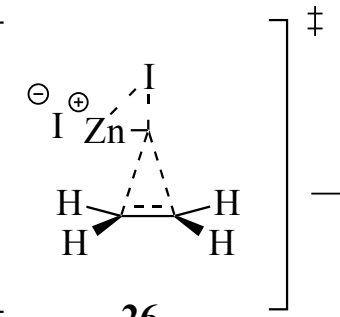

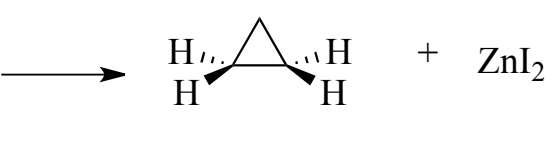

27
B)<smiles>O[C@H]1C=CCCC1</smiles>

31

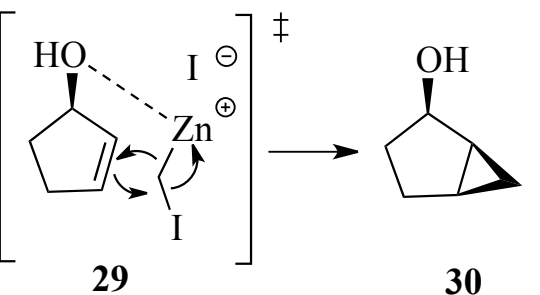

30 $67 \%$, d.e. $>99 \%$<smiles>O[C@@H]1CCCCC2CC21</smiles>

32

Scheme 2.1: (A) Proposed mechanism for the Simmons-Smith reaction, indicating the proposed transition state through the complexation of the zinc iodide. ${ }^{64}$ (B) Stereoselective addition of the cyclopropane directed through oxygen complexation with organozinc. ${ }^{65}$ 


\subsubsection{Mąkosza gem-dihalocyclopropanation}

Doering and Hoffmann were the first to report the synthesis of gemdihalocyclopropane, with the synthesis of both dichloro- and dibromocyclopropanes in $1954 .^{66}$ This was achieved through the addition of chloroform to a solution of cyclohexane, potassium tert-butoxide and tert-butyl alcohol, which proceeds through an $\alpha$-elimination of hydrochloric acid and formation of the dichlorocarbene. ${ }^{66}$ However, emphasis was put on this reaction needing to occur under anhydrous conditions due to the rapid reaction of dichlorocarbene with water. Mąkosza and Wawrzyniewicz reported an improvement of this synthesis in $1969,{ }^{67}$ in which dichloro- and dibromocyclopropanes were synthesised from the corresponding haloforms in the presence of concentrated sodium hydroxide and catalytic amounts of triethylbenzylammonium chloride (TEBAC). Although the reaction was carried out under aqueous conditions, it was reported that only a small percentage (approximately $7 \%$ ) of the dihalocarbene reacted with water. This is due to the use of TEBAC as a quaternary ammonium phase-transfer catalyst. ${ }^{67}$ In this two-phase catalytic system, the haloform is initally deprotonated by the aqueous sodium hydroxide at the interfacial region of the reaction, forming the sodium haloform salt (scheme 2.2A). The haloform anion then complexes with the quaternary ammonium salt at the interfacial region, allowing it to enter the organic phase, where it begins to decompose into the highly reactive carbene (scheme 2.2B). The carbene can then react with the alkene to form the desired cyclopropane (scheme 2.2C). ${ }^{67,60}$

Unlike the Simmons-Smith cyclopropanation, addition of the carbene is not directed through the oxygen substituent, instead the addition of the carbene across the alkene is directed through steric interactions, where the carbene is stereoselectively added across the sterically less hindered face. ${ }^{68,3}$ The Mąkosza cyclopropanation provides an effective and high yielding synthesis of gem-dihalocyclopropanes due to the biphasic nature of the reaction, preventing the harsh aqueous condition from promoting any undesirable side reactions, such as ring opening reactions, without the need to keep the reaction in absolutely anhydrous conditions as seen in the methodology proposed by Doering and Hoffmann. ${ }^{66}$ 


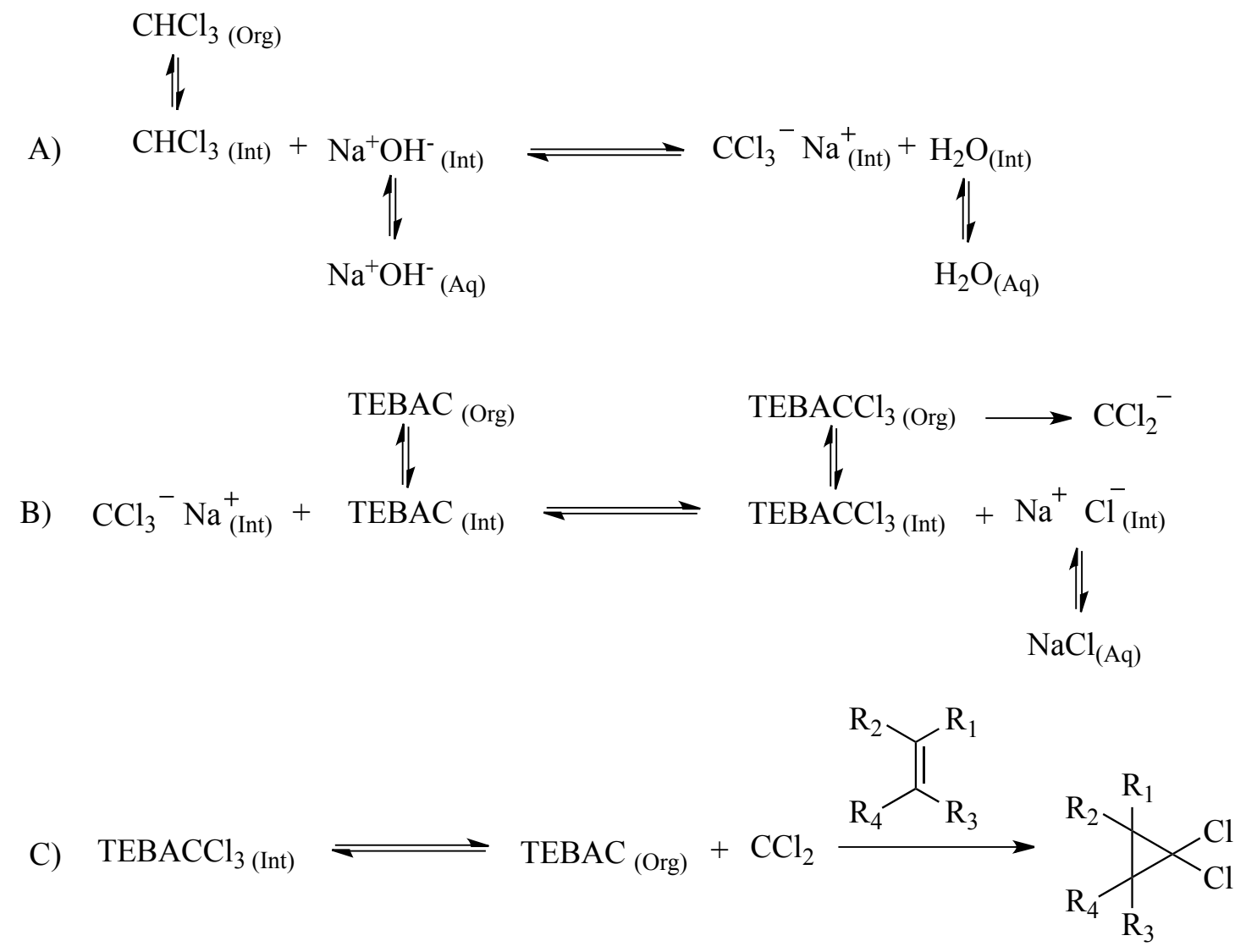

Scheme 2.2: Mąkosza cyclopropanation mechanism, indicating phase shifts (Org: organic phase; Int: interphase; Aq: Aqueous); (A) Deprotonation of chloroform; (B) Complexation of the quaternary ammonium cation with the chloroform anion; (C) Decomposition of quaternary ammonium and chloroform, formation of the carbene and synthesis of the cyclopropane.

TEBAC $=$ Benzyltriethylammonium chloride

\subsubsection{Diazoester cyclopropanation}

The decomposition of diazo compounds into carbenes has been employed for more than a hundred years, ${ }^{69}$ however, the suggestion that the bond formation between the transition-metal catalyst and the diazo compounds promotes the ejection of the dinitrogen species was only proposed some 50 years ago by Peter Yates. ${ }^{70}$ Here, Yates hypothesised that after the ejection of the dinitrogen species the carbene remained bound to the metal catalyst (scheme 2.3) ${ }^{70}$ A milestone in the catalytic use of copper in this manner came many years later when Salomon and Kochi reported the use of copper triflate as an effective metal catalyst in the addition of diazocompounds to an alkene. The addition caused a reduction of copper (II) to copper (I), 
confirming that copper (I) is the active catalyst in the transformation of the carbenoid. $^{71}$

Although very effective copper catalysts were still being discovered, ${ }^{71}$ the coinciding use of palladium (II) acetate and rhodium (II) acetate by Teyssie and colleagues ${ }^{72,73}$ was proving far more successful. In the case of rhodium acetate, this is due to the thermal and air stability of the catalyst, its inability to undergo $\pi$ - $\pi$ interaction with the alkene as well as its coordination unsaturation. As rhodium acetate is a binuclear compound with $\mathrm{D}_{4 \mathrm{~h}}$ symmetry and four bridging acetates it possesses only one empty axial coordination site per metal atom. ${ }^{69}$ At the stable oxidation state of +2 with five surrounding ligands (four metal-oxygen bonds and one metal-metal bond), rhodium acetate is a coordinatively unsaturated catalyst as it is lacking two electrons to satisfy the 18 electron rule. This means rhodium acetate does not need to undergo ligand displacement before it becomes a reactive catalyst, making it an effective electrophile, readily undergoing nucleophilic attack by the diazo compounds (scheme 2.3).

The proposed mechanism for the rhodium carboxylate begins with the generation of a metal-carbene species, which adds across the alkene at a later stage to form the cyclopropane, completing the catalytic cycle (scheme 2.4). The suggested formation of the carbenoid occurs through the complexation of the electrophilic $\alpha$-centre onto the metal catalyst. This in turn leads to the ejection of nitrogen gas to form the carbon-metal double bond (scheme 2.3). Position of the alkene and overall stereochemistry depends on the steric effects of the substituents on both the diazocompound and the alkene. In the absence of any dominating steric effects synstereoselectivity is typically observed, with the ratio of syn/anti decreasing as the steric bulk of both the alkene and diazo-compound increases. ${ }^{74,69}$ As expected, the addition of the carbene favourably occurs across the sterically less hindered face. Diazoester cyclopropanation provides an effective way to introduce a cyclopropane moiety into a compound, particularly due to the high controllability of the resulting stereochemistry established by metal catalysts such as rhodium acetate. 
<smiles>[R]C([R])=[N+]=[N-]</smiles>

33

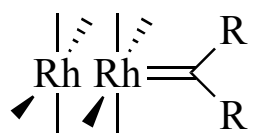

36<smiles>[R]C(C)[N+]#N</smiles>

4

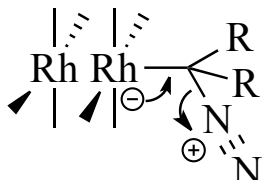

35

Scheme 2.3: Mechanism for the formation of a carbenoid species. 35 shows the ejection of the dinitrogen and the formation of the carbenoid species $36 .{ }^{75}$

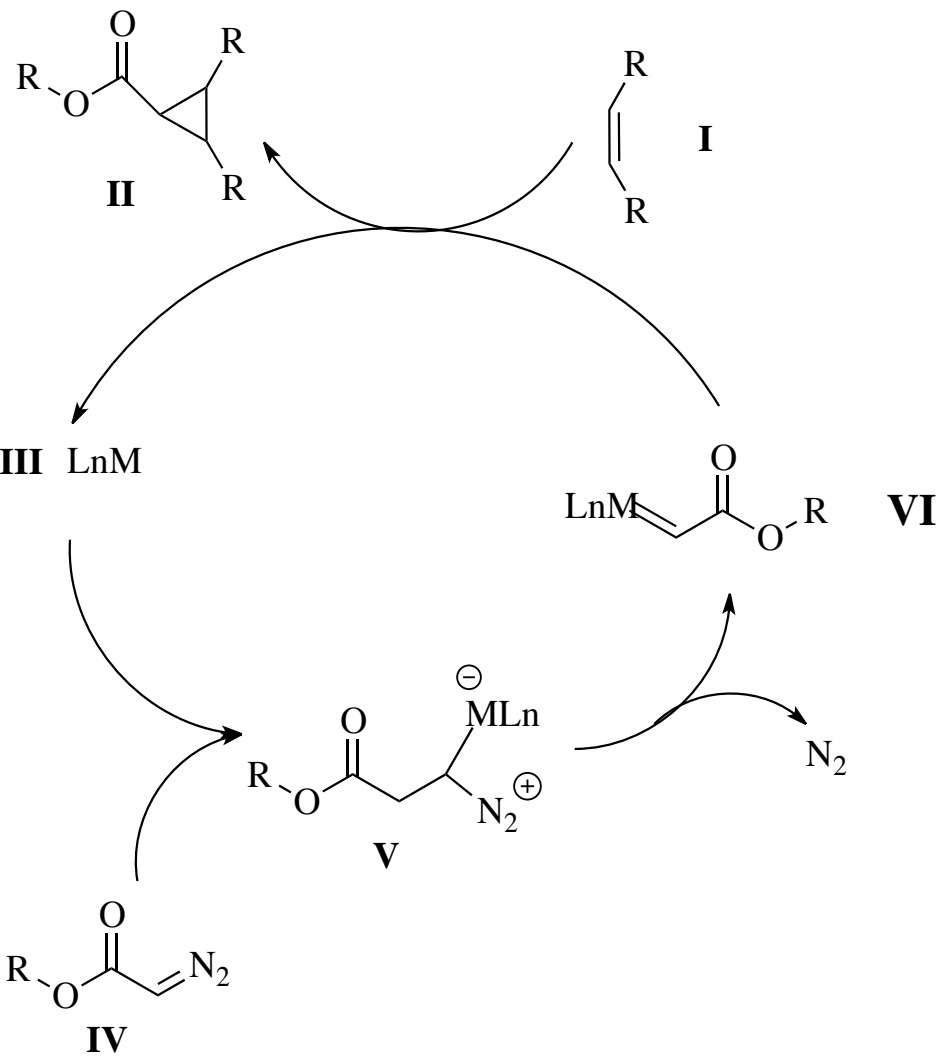

Scheme 2.4: Catalytic cycle of carbenoid cyclopropanation. 


\section{Results and discussion}

\subsection{Synthesis of 1,5-Anhydro-3,4-di- $O$-benzyl-2-deoxy-6- $O$-trityl-D- arabino-hex-1-enitol (40)}

The use of glycals as precursors for the synthesis of 1,2-cyclopropyl carbohydrates is well precedented in literature as reported by Hoberg, ${ }^{76,77}$ Nagarajan ${ }^{68}$ and Harvey. ${ }^{3,34}$ Synthesis of 1,2-cyclopropyl carbohydrates is commonly achieved by the addition of a carbene to the glycal alkene through one of the three methods discussed in section 2.2. Throughout this project the protected glucal 1,5-anhydro-3,4-di-O-benzyl-2deoxy-6-O-trityl-D-arabino-hex-1-enitol (40) was used as a substrate for the synthesis of 1,2-cyclopropyl carbohydrates, as its derivatives have been shown to facilitate bioactivity. $^{2}$ It can also be readily synthesised from D-glucose (63) in five steps (scheme 2.5). Methodology for the synthesis of glucals was initially developed by Karl Zach and Emil Fischer in $1913^{78}$ and subsequently optimised by others. ${ }^{79,80}$ Synthesis of 39 proceeded with the per-acetylation of D-glucose (63) via the addition of acetic anhydride and catalytic amounts of perchloric acid. The resulting peracetylated glucose was subjected to a selective substitution reaction at the $\mathrm{C}-1$ position through the addition of $\mathrm{HBr}$ leading to isolation of the $\alpha$-bromoglycoside (64) intermediate as a white solid. Following its isolation, the crude glucosyl halide 64 was then taken up in a solution of $\mathrm{H}_{2} \mathrm{O}$, acetic acid and zinc dust to undergo a reductive elimination reaction, ${ }^{81}$ where the anomeric bromide and the C-2 acetyl group are eliminated, resulting in the formation of the 1,2-alkene 37 in a $65 \%$ yield over 3 steps. Addition of a reduced amount of $\mathrm{HBr}$ compared to literature led to the formation and isolation of the by-product glucose penta-acetate, resulting in the overall moderate yield of $\mathbf{3 7}$.<smiles>OC[C@H]1O[C@H](O)[C@@H](O)[C@H](O)[C@@H]1O</smiles>

63
1) $\mathrm{Ac}_{2} \mathrm{O}$, Cat. $\mathrm{HClO}_{4}$

$90 \mathrm{~min}, 40-50{ }^{\circ} \mathrm{C}$

2) $\mathrm{HBr}, \mathrm{AcOH}$

90 min, r.t.

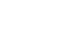<smiles>CC(=O)OCC1O[C@H](Br)[C@H](OC(C)=O)[C@H](OC(C)=O)[C@H]1OC(C)=O</smiles>

64

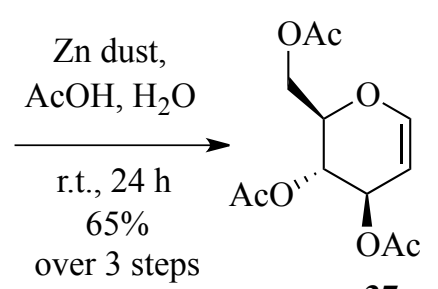

37

Scheme 2.5: Synthesis of tri-O-acetyl-D-glucal (37). 
The de-acetylation of $\mathbf{3 7}$ is a well-documented reaction with many established procedures. Reaction conditions developed by Czernecki and colleagues ${ }^{82}$ involving methanol and an anion exchange resin resulted in high yields, however, reaction times of approximately 15 hours made the reaction undesirable. Therefore, a modification by Moore and colleagues ${ }^{35}$ involving Zemplén type conditions, was preferred, with the much shorter reaction time of approximately 15 minutes. Accordingly, the triacetate 37 was dissolved in methanol and treated with catalytic amounts of solid sodium, resulting in the in situ formation of sodium methoxide to yield the crude deprotected glucal 38 within 15 minutes. The isolated crude material was then subjected to purification via the successive additions of methanol, acetone and diethyl ether, allowing for precipitation and therefore removal of any impurities, resulting in an overall yield of $99 \%$ of the pure triol $\mathbf{3 8}$ (scheme 2.6).<smiles>CC(=O)OCC1OC=CC(OC(C)=O)C1C(=O)O</smiles>

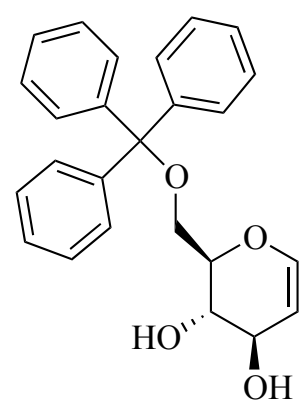

39

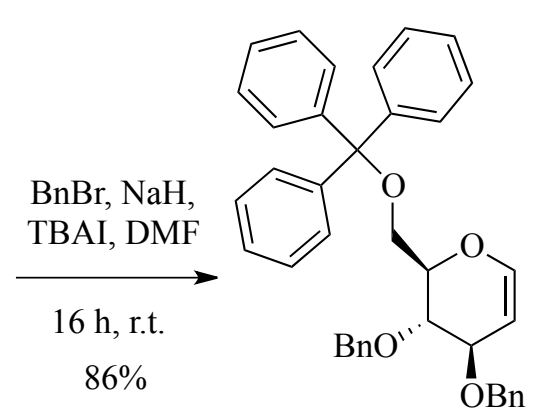

40

Scheme 2.6: Synthesis of 1,5-anhydro-3,4-di-O-benzyl-6- $O$-trityl-D-arabino-hex-1-enitol (40).

In order to retain the integrity of the cyclopropane that will eventually be installed, an orthogonal protecting group in relation to the highly strained cyclopropane group was required. To this end, trityl chloride was chosen to selectively protect the C-6 OH group due to its mild acid-mediated deprotecting conditions, which would avoid the possibility of base-mediated cyclopropane ring opening reactions or benzyl 
deprotection. ${ }^{34,68}$ In a modification of the procedure published by Schmidt and colleagues, ${ }^{83}$ protection of the primary hydroxyl on the triol $\mathbf{3 8}$ was achieved through the addition of trityl chloride to a solution of $\mathbf{3 8}$ in a 1:1 mixture of pyridine:dichloromethane (v:v), resulting in high yields of the mono-protected glucal 39. This then allowed for the protection of both secondary alcohols at the C-3 and C-4 positions. Benzylation was achieved through a modification of the methodology reported by Schmidt and colleagues, ${ }^{84}$ wherein diol 39 was dissolved in DMF followed by the slow addition of $\mathrm{NaH}$ and $\mathrm{BnBr}$. Initial benzylation attempts were low yielding due to the inability to keep the reaction under anhydrous conditions. Optimisation of the reaction through the prior co-evaporation of the starting material 39 with DMF to remove traces of water, along with the addition of the TBAI to provide a source of iodide anions for a nucleophilic displacement reaction, proved to be very successful, yielding $\mathbf{4 0}$ in high yields (86\%). No C-4 mono-benzylated product was isolated as often seen in literature. ${ }^{36}$

\subsection{Synthesis of gem-dichlorocyclopropane}

Brimacombe and colleagues ${ }^{85}$ reported the first addition of a carbene to an unsaturated sugar in 1967 through a modification of the initial cyclopropanation procedure proposed by Doering and Hoffmann. ${ }^{66}$ However, the essentiallity of highly anhydrous conditions made this reaction particularly challenging. To this end, Gross and colleagues ${ }^{86}$ utilised a modification of the methodology proposed by Mąkosza ${ }^{67}$ in the synthesis of cyclopropane-containing compounds from unsaturated sugars, in which a phase transfer catalyst was used, allowing for the use of a $50 \%(\mathrm{w} / \mathrm{w})$ solution of aqueous sodium hydroxide. Reactions times ranged from 1-6 hours resulting in yields of $\geq 96 \%$. This provided the first reported synthesis of a small library of unsaturated cyclopropyl carbohydrates under aqueous conditions. Nonetheless, due to the safety hazards associated with the high concentration of sodium hydroxide utilised in the synthesis proposed by Gross and colleagues, optimisation of the reaction was necessary.

Using a modification of the procedures employed by Gross and colleagues, ${ }^{86}$ the protected glucal 40 was dissolved in chloroform and treated with the phase transfer 
catalyst TEBAC. In attempts to reduce the high concentration of sodium hydroxide used by Gross, ${ }^{86}$ the reaction was treated with the dropwise addition of a $33 \%(\mathrm{w} / \mathrm{w})$ solution of aqueous sodium hydroxide. As expected, the reduction in sodium hydroxide concentration led to a longer reaction time of two days compared to the reported 6 hours. This, however, still successfully yielded both the major (41) and the minor (42) product in yields of $83 \%$ and $13 \%$, respectively (scheme 2.7 ) which is comparable to those achieved by Gross. Conceivably, the isolated major stereoisomer resulted from the addition of the carbene to the $\alpha$-face of the glucal due to the steric hindrance exerted by the C-3 benzyl group as well as the bulky C-6 trityl protecting group.

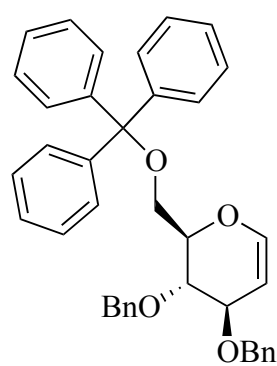

40

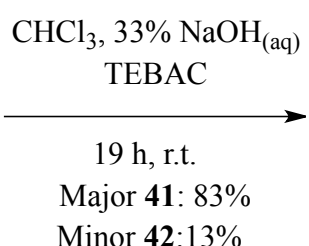

Minor 42:13\%

Scheme 2.7: Synthesis of cyclopropane derivatives $\mathbf{4 1}$ and $\mathbf{4 2 .}$

Separation of the two stereoisomers was achieved through silica column chromatography utilising a 14:1 (v:v) hexanes:ethyl acetate solvent system. Only the major $\alpha$-stereoisomer 41 was utilised throughout the rest of this thesis as this stereochemistry was shown to be favourable for the compound's bioactivity. ${ }^{2}$

${ }^{1} \mathrm{H}$ NMR data for the major product 41 matched those previously reported by Nagarajan and colleagues. ${ }^{68}$ Successful cyclopropanation was marked by the noticeable upfield shift in H-1 from 6.49 ppm in the glucal $\mathbf{4 0}$ to 4.05 ppm (doublet, $J_{\mathrm{H} 1-\mathrm{H} 2}=8 \mathrm{~Hz}$ ) and $\mathrm{H}-2$ from $4.88 \mathrm{ppm}$ to $1.89 \mathrm{ppm}$ (doublet of doublets, $J_{\mathrm{H}-\mathrm{H}}=8.1$, $4.9 \mathrm{~Hz}$ ). The assignment of the spectral data of the minor product 42 was consistent with that proposed by Moore, ${ }^{36}$ with again a notable shift in $\mathrm{H}-1$ when compared to the glucal starting material 40 from $6.49 \mathrm{ppm}$ to $4.05 \mathrm{ppm}$ (doublet, $J_{\mathrm{H} 1-\mathrm{H} 2}=8.1 \mathrm{~Hz}$ ) 
and $\mathrm{H}-2$ from $4.88 \mathrm{ppm}$ to $2.12 \mathrm{ppm}$ (triplet, $J_{\mathrm{H}-\mathrm{H}}=7.8 \mathrm{~Hz}$ ) as shown in figure 2.0 Small amounts of inseparable impurities were present in 42, however, this stereochemistry has been shown to yield little bioactivity as an $\mathrm{IC}_{50}$ of $300 \mu \mathrm{m}$ in $p d r 1 \Delta p d r 3 \Delta x x x \Delta$ yeast deletion sets was reported by Davies ${ }^{2}$, therefore no further synthetic efforts were taken with this compound. Successful cyclopropanation was also confirmed by HMBC through the coupling of C-7 (61 ppm) to H-2 (4.88 ppm) and $\mathrm{H}-3$ (4.17 ppm).

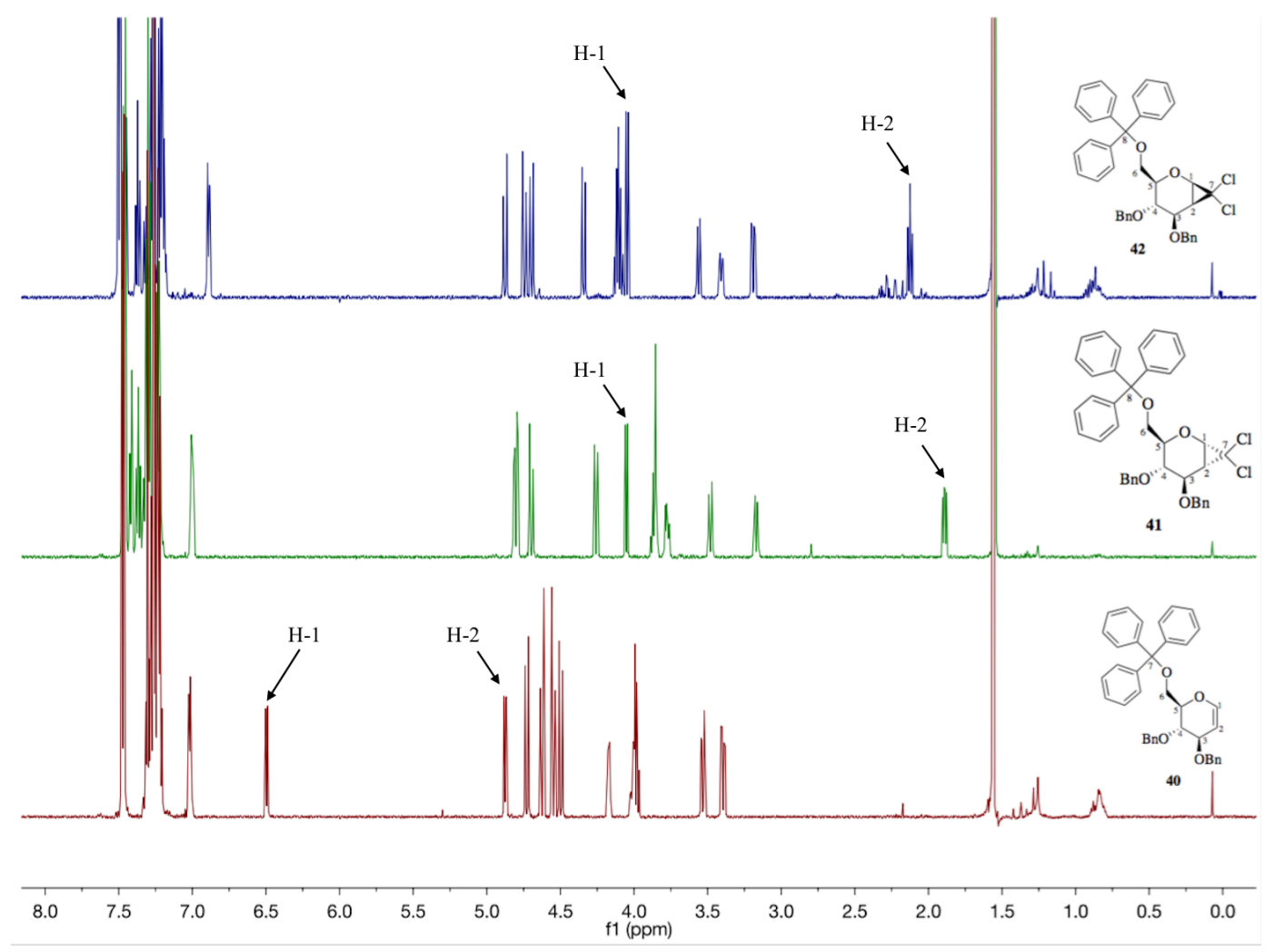

Figure 2.0: ${ }^{1} \mathrm{H}$ NMR of compound $\mathbf{4 0}$ (red), $\mathbf{4 1}$ (green) and $\mathbf{4 2}$ (blue) showing noticeable upfield shifts in both $\mathrm{H}-1$ and $\mathrm{H}-2$.

Acid-mediated deprotection of the C-6 trityl group was demonstrated by Nagarajan and colleagues ${ }^{68}$ via the dropwise addition of formic acid. However, it was later noticed that the unexpected formation of the by-product 43 resulted from the esterification of the primary alcohol on $\mathbf{2 3}$ with formic acid under the acidic conditions. ${ }^{36}$ Reaction conditions were optimised by Davies ${ }^{2}$ in order to reduce the production of the formate ester by-product. Although some of the formate ester byproduct was still formed, optimised conditions recommended a reaction time for 2 
hours in diethyl ether resulting in a 7:3 ratio in favor of the desired product at a $45 \%$ yield, along with the recovery of $20 \%$ starting material. ${ }^{2}$ Despite the recovered starting material, this was a substantial improvement from the previous synthesis where an isolated yield of $22 \%$ was reported in a 1:2.5 ratio in favor of the formate ester by-product. In the current study, synthetic attempts using the reaction conditions proposed by Davies, led to low yields and a 1:1 ratio of the desired product (23) to by-product (43). Therefore optimisation of the reaction proposed by Nagarajan and colleagues $^{68}$ was undertaken by slightly increasing the concentration of formic acid and decreasing the amount of solvent, in turn concentrating the reaction. The reaction was then very closely followed by TLC analysis and quenched after 50 min resulting in high yields and a 9:1 ratio of the desired product (23) to the formic ester by-product (43) (scheme 2.8). Optimisation of the workup proposed by Nagarajan and colleagues ${ }^{68}$ was also undertaken as it was noted by Moore ${ }^{59}$ that the concentration of the reaction, before the dilution with dichloromethane as initially proposed by Nagarajan, resulted in conditions favourable for ester formation. The reaction was therefore quenched with diethyl ether and washed with saturated sodium bicarbonate before the concentration of the crude material. These changes led to production of the desired deprotected alcohol $\mathbf{2 3}$ in $81 \%$ yield, a substantial improvement from the previously reported $45 \% .^{2}$

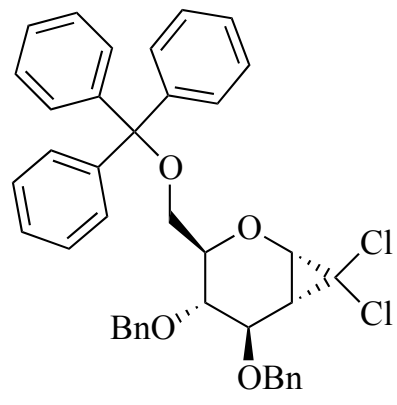

41

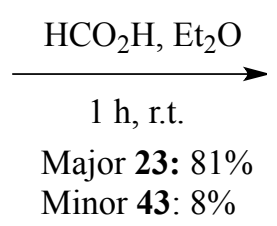

Minor 43: 8\%<smiles>OC[C@H]1O[C@@H]2[C@H]([C@@H](OBr)[C@@H]1Br)C2(Cl)Cl</smiles>

23<smiles>O=COC[C@H]1O[C@@H](C(Cl)(Cl)Cl)[C@@H](Br)[C@@H]1Br</smiles>

43

Scheme 2.8: Synthesis of $\mathbf{2 3}$ and 43. 


\subsection{Synthesis of $(((2 R, 3 S, 4 R)-3,4-b i s(b e n z y l o x y)-3,4-d i h y d r o-2 H-$ pyran-2-yl)methoxy)(tert-butyl)diphenylsilane (45)}

Before the optimisation of the trityl deprotection reaction (scheme 2.8) was undertaken, alternative primary alcohol protecting groups were explored due to the loss of yield caused by the formation of the formate ester by-product during detritylation. ${ }^{36} \mathrm{~A}$ literature search revealed several alternative C-6 protecting groups, however, the decision to use tert-butyldiphenylsilyl chloride (TBDPSCl) was made due to two factors. Firstly, selective deprotection of TBDPSCl occurs through the use of tetrabutylammonium fluoride hydrate (TBAF) at very moderately basic conditions, reducing the likelihood of base-mediated cyclopropane ring opening, ${ }^{34,68,36}$ along with orthogonality with benzyl protecting groups. ${ }^{87}$ Secondly, the use of a bulky protecting group would increase the facial steric effects, leading to a higher stereoselectivity for cyclopropane formation on the $\alpha$-face of the carbohydrate. ${ }^{61}$ The literature also indicated no significant reduction in yield during both protection and deprotection using TBDPSCl. ${ }^{88,89,90}$

The use of TBDPSCl as a primary protecting group on unsaturated carbohydrates has become prevalent in the literature since it was first reported in 1976 by Guthrie and colleagues. ${ }^{91}$ In a modification of the procedure written by Lellouche and colleagues, ${ }^{92}$ a solution of the triol $\mathbf{3 8}$ and imidazole in DMF was treated with a slight excess of the TBDPSCl at low temperatures (scheme 2.9). It was important to keep the temperature low and the amount of TBDPSCl close to stoichiometric to prevent the undesirable protection of either the C-3 or C-4 hydroxyl groups. Due to the sensitivity of TBDPSCl to water, it was also important to keep the reaction anhydrous. To this end, imidazole was co-evaporated with toluene three times, followed by the co-evaporation of the starting material $\mathbf{3 8}$ and imidazole with DMF to remove any traces of water. However, the reaction resulted in disappointing yields, which was accounted for by the poor quality of the TBDPSCl as two spots were seen on the TLC of the reagent and ${ }^{1} \mathrm{H}$ NMR spectroscopy of the TBDPSCl showed the presence of TBDPSOH, indicating the presence of water in the reagent. 
It was also suspected that $\mathbf{4 4}$ could undergo silyl migration during the benzylation reaction of the secondary C-3 and C-4 hydroxyl groups as reported in the literature, ${ }^{92}$ therefore assessment of this was first undertaken before attempting to improve the yields of the previous reaction. In an optimisation of the method proposed by Lellouche, ${ }^{92} \mathrm{BnBr}$ was added to a solution of the diol 44 in DMF prior to the slow addition of $\mathrm{NaH}$ in an attempt to reduce the chances of any silyl migration. No silyl migration was observed, however, the mono-benzylated by-product (63) was observed after the reaction in addition to the desired product 45 (scheme 2.9). Benzylation had been expected to occur at the less sterically hindered C-3 hydroxyl group first, but this was contrary to the isolation of $\mathbf{6 3}$ in a $30 \%$ yield. Whilst waiting for delivery of new, dry TBDPSCl the decision to optimise the detritylation reaction was undertaken resulting in very favourable results (section 2.4, scheme 2.8). It was therefore decided to continue along that synthetic route and further optimisation of TBDPSCl was not undertaken.<smiles>CC(C)(C)[Si](OC[C@H]1OC=C[C@@H](O)[C@@H]1O)(c1ccccc1)c1ccccc1</smiles>

38

44<smiles>CC(C)(C)[Si](OC[C@H]1OC=C[C@@H](O)[C@H]1O)(c1ccccc1)c1ccccc1</smiles>

Scheme 2.9: TBDPSCl protection and syntheses of compounds $\mathbf{4 4 ,} \mathbf{4 5}$ and $\mathbf{6 3}$. 


\subsection{Synthesis of the ethoxycarbonyl substituted 1,2-cyclopropyl carbohydrates 54 and 55.}

Due to the hypothesis that mechanism-based inhibition of the dichloropropyl derivative $\mathbf{2 3}$ occurred through a ring opening reaction and formation of a carbanion (scheme 1.6), the carboxy ether cyclopropane 24 became the new synthetic target. Enolate stabilisation of the carbanion was hypothesised to encourage ring opening reactions. Therefore the synthesis of diazoacetates, in particular ethyl diazoacetate (49) was undertaken. In a modification of a procedure reported by Patnaik and colleagues, ${ }^{93}$ glycine was added to a pre-mixed solution of acetyl chloride and ethanol to undergo a Fischer esterification reaction, yielding 47 quantitatively (scheme 2.11). As shown in scheme 2.10A, the pre-mixing of acetyl chloride and ethanol provides an anhydrous source of $\mathrm{HCl}$. The resulting acidic conditions allow for the protonation of the glycine carbonyl and initiates the Fischer esterification reaction (scheme 2.10B). ${ }^{94}$ This reaction was repeated to synthesise the methyl and butyl derivatives, $\mathbf{4 6}$ and $\mathbf{4 8}$, respectively, from the corresponding alcohols in quantitative yields (scheme 2.11). The syntheses of $\mathbf{4 6 , 4 7}$ and $\mathbf{4 8}$ as hydrochloride salts provided greater stability of the compounds. ${ }^{95}$

A)

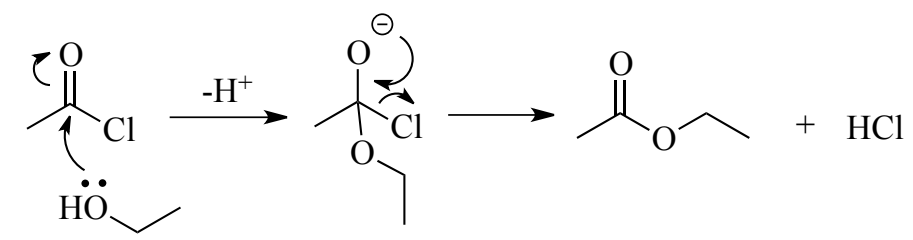

63

64

65

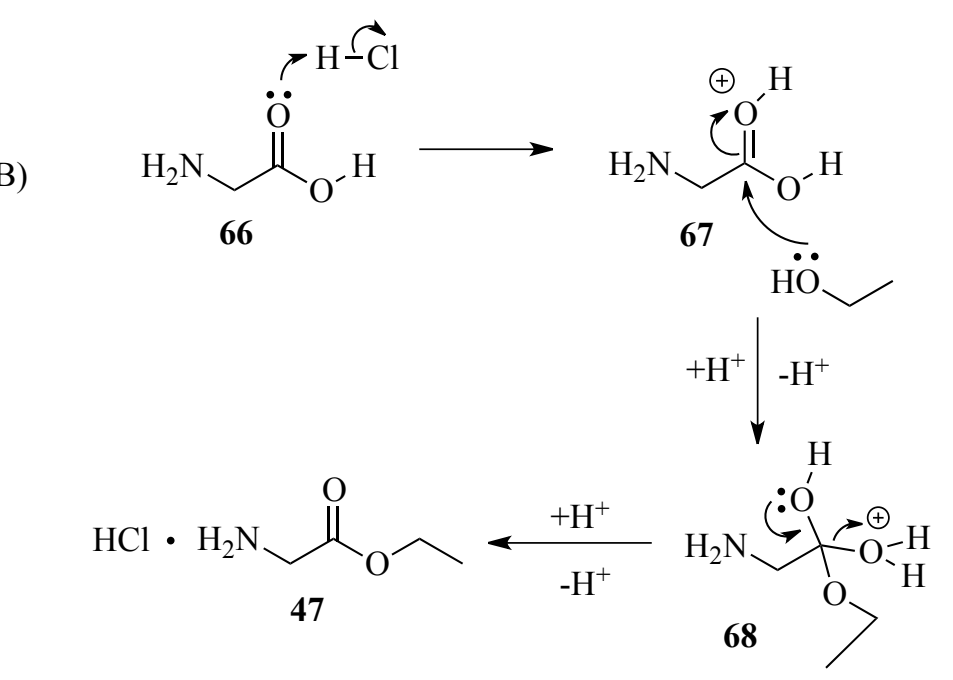

3ficheme 2.10: A) In situ synthesis of $\mathrm{HCl}$ through esterification of acetyl chloride (63). B) Fischer esterification of glycine (66) for the synthesis of ethyl glycine hydrochloride (47). 
Since the synthesis of the first diazo compound over 100 years ago, ${ }^{96}$ new versatile and effective methodologies have been developed. ${ }^{97}$ Much effort is focused around creating safer synthetic routes for these explosive compounds ${ }^{98,99}$ or making them more environmentally friendly by removing the necessity for heavy metals. ${ }^{97 b}$ To this end, a modification of the well-documented procedure initially published by Searle ${ }^{100}$ in 1955 was utilised ${ }^{101,97}$ where ethyl glycinate hydrochloride 47 was reacted with sodium nitrite at $-9{ }^{\circ} \mathrm{C}$. Care was taken to maintain the reaction at $-9{ }^{\circ} \mathrm{C}$ during the addition of concentrated sulfuric acid as increases in temperature have been reported to result in reduced yields. Due to the explosive nature of the diazo compound 49 , the final product was not concentrated and a yield of $70 \%$ was assumed as per the literature (scheme 2.11). ${ }^{100}$ Furthermore, due to the specific warning about the especially explosive nature of methyl diazoacetates (69), ${ }^{100}$ it was decided to discontinue its synthesis.

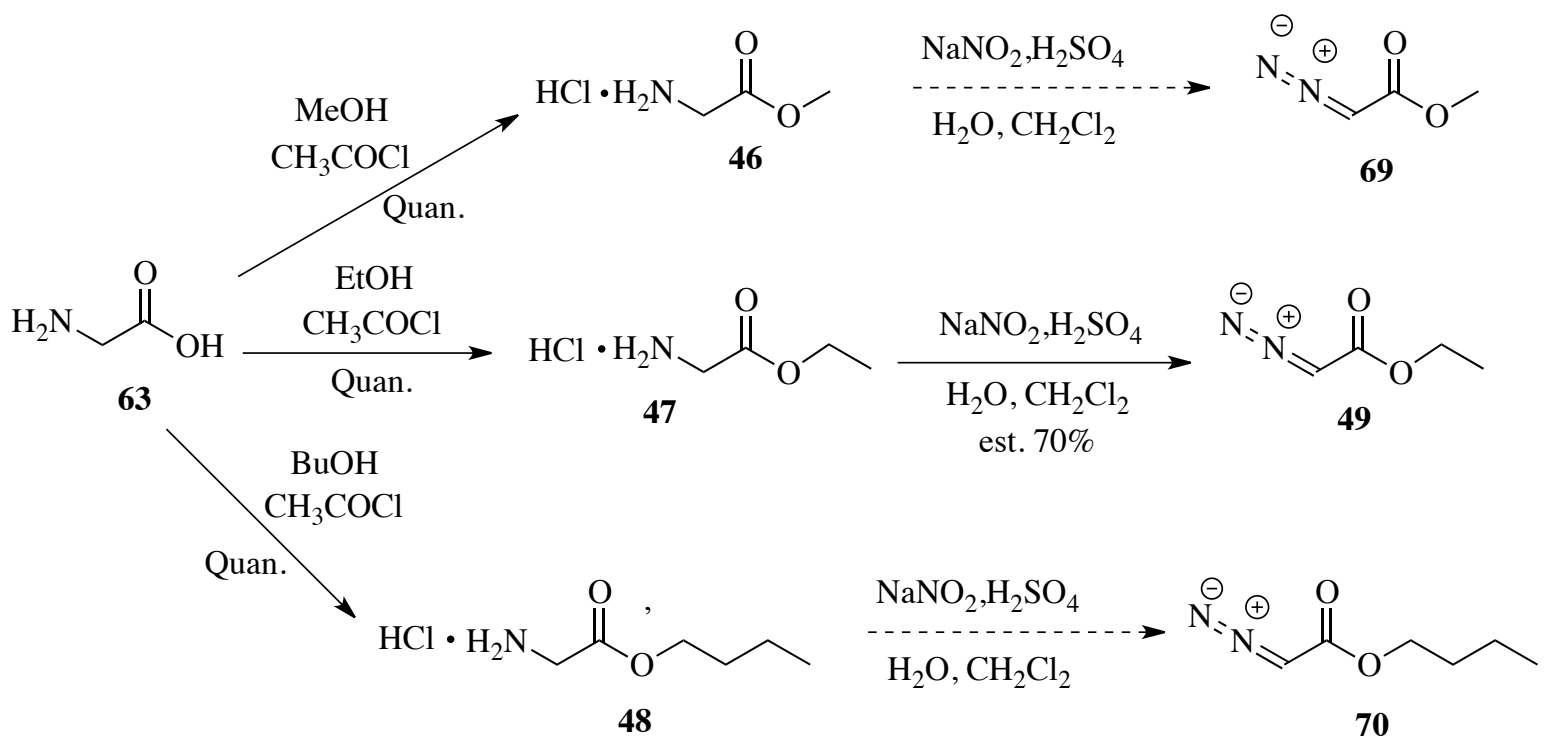

Scheme 2.11: Syntheses of compounds 46, 47, 48 and 49. Proposed syntheses of 69 and 70 was not undertaken due to safety concerns around the explosive nature of the compounds.

For the syntheses of cyclopropyl carbohydrates 54, 55, 56, several different catalysts and procedures were considered. Although palladium and copper catalysts are known to form metal-alkene pre-complexes which allows for a more directed stereoselective addition of the carbenoid across the alkene, ${ }^{102}$ rhodium acetate was selected for the following synthesis due to the higher yields reported in literature and reasons 
discussed in section 2.2.3. ${ }^{102,72,76}$ It was also believed that, due to the steric effects of the C-3 and C-4 benzyl groups along with the C-6 trityl protecting group on the diol 40, steric hindrance would favour selective addition of the carbenoid from the desired $\alpha$-face of the alkene. Due to the likeness of starting materials, methodology proposed by Timmers and colleagues ${ }^{103}$ was first employed. Although methodology for the cyclopropanation of the substrate triacetyl glucal was well-precedent in the literature, it was believed that the added steric stress of the benzylated glucal utilised in the procedure proposed by Timmer and colleagues ${ }^{103}$ would give a more accurate representation of the substrate $\mathbf{4 0}$. Thus, protected glucal $\mathbf{4 0}$ was treated with ethyl diazoacetate (EDA) over 1 hour, however this resulted in a 95\% recovery in starting material (table 2.0, entry 1). Accordingly, optimisation of the reaction was undertaken as shown in table 1 . Hoberg and colleagues ${ }^{76}$ reported that rapid addition of EDA to unsaturated glucals causes a decomposition of the EDA species, the formation of ethyl fumarates and the recovery of the starting material. The addition of the EDA was thus extended to a dropwise addition over 4 hours according to the procedure proposed by Risseeuw and colleagues, ${ }^{104,105}$ however this still led to a disappointing yield and large amount of recovered starting material (entry 2).

\begin{tabular}{|l|l|l|l|l|l|l|}
\hline Entry & $\begin{array}{l}\text { Glucal } \\
\text { (equiv.) }\end{array}$ & $\begin{array}{l}\text { Time } \\
\text { (hours) }\end{array}$ & $\begin{array}{l}\text { Temperature } \\
\left({ }^{\circ} \mathbf{C}\right)\end{array}$ & $\begin{array}{l}\text { Rhodium } \\
\text { Acetate }\end{array}$ & $\begin{array}{l}\text { Rhodium } \\
\text { acetate equiv. }\end{array}$ & Yield \\
\hline 1 & $\mathbf{4 0}(1.5)$ & 1 & r.t & Sigma (1) & 0.5 & $\begin{array}{l}0 \% \\
(95 \% \mathrm{SM})\end{array}$ \\
\hline 2 & $\mathbf{4 0}(1.5)$ & 4 & r.t & Sigma (1) & 0.5 & $\begin{array}{l}7 \% \\
(90 \% \mathrm{SM})\end{array}$ \\
\hline 3 & $\mathbf{4 0}(1.5)$ & 14 & r.t & Sigma (1) & 0.05 & $\begin{array}{l}25 \% \\
(61 \% \mathrm{SM})\end{array}$ \\
\hline 4 & $\mathbf{3 8}(3)$ & 14 & r.t & Sigma (1) & 0.05 & $\begin{array}{l}0 \% \\
(60 \% \mathrm{SM})\end{array}$ \\
\hline 5 & $\mathbf{3 8}(3)$ & 12 & 40 & Sigma (1) & 0.05 & $\begin{array}{l}3 \% \\
(81 \% \mathrm{SM})\end{array}$ \\
\hline 6 & $\mathbf{3 8}(3)$ & 12 & r.t & $\begin{array}{l}\text { Compound } \\
\mathbf{5 0}\end{array}$ & 0.05 & $\begin{array}{l}21 \% \\
(37 \% \mathrm{SM})\end{array}$ \\
\hline 7 & $\mathbf{4 0}(3)$ & 12 & r.t & Sigma (2) & 0.05 & $\begin{array}{l}28 \% \\
(70 \% \mathrm{SM})\end{array}$ \\
\hline 8 & $\mathbf{4 0}(3)$ & 1 & r.t & Sigma (2) & 0.05 & $\begin{array}{l}0 \% \\
(90 \% \mathrm{SM})\end{array}$ \\
\hline 9 & $\mathbf{4 0}(3)$ & 14 & r.t & Sigma (2) & 0.05 & $\begin{array}{l}58 \% \\
(21 \% \mathrm{SM})\end{array}$ \\
\hline
\end{tabular}

Table 2.0: Optimisation of diazoester cyclopropanation reaction. Sigma (1) and Sigma (2) represents the $1^{\text {st }}$ and $2^{\text {nd }}$ batch of rhodium acetate purchased from Sigma respectively. All yields reported are combined yield of both stereoisomers. 
A slower addition of EDA of 14 hours improved the yield to $25 \%$, nonetheless an appreciable amount of starting materials were still recovered (entry 3). This was thought to be due to the high steric bulk of the alkene $\mathbf{4 0}$ impeding the addition of the carbenoid to the alkene, as increases in the size of the glucal substituents have been shown to cause a reduction in yield. ${ }^{76}$ Therefore the fully unprotected model glucal $\mathbf{3 8}$ was used to evaluate the influence of steric hindrance of the starting materials. However, comparable yields to literature ${ }^{76}$ were not obtained even at higher temperatures as shown in entries 4 and 5 . The results put doubt on the purity of the rhodium acetate, which prompted the synthesis of fresh rhodium acetate.

The synthesis of rhodium acetate was undertaken by the treatment of hydrated rhodium trichloride with sodium acetate in methanol. Crystallisation of the reaction mixture allowed for the formation of the methanol adduct $\left(\mathrm{Rh}\left(\mathrm{OAc}_{2}\right) \mathrm{MeOH}\right)$, where methanol is bound as a ligand, which upon drying yielded the active rhodium acetate (50) in a 28\% yield. Not only did the use of the newly synthesised rhodium acetate on the triol 38 give higher yields, but more importantly, this gave the lowest amount of recovered starting materials yet (entry 6), indicating a much more reactive catalyst. Thus, a newly purchased batch of rhodium acetate was used with the benzylated glucal 40 under the same conditions to give modest yields similar to those obtained before (entry 7). To confirm the effect given by the speed of EDA addition, the reaction was repeated where EDA was added over an hour, which proved unsuccessful (entry 8). Finally, increasing the time of addition to 14 hours resulted in a favourable yield of 58\% (entry 9) for the desired stereoisomers $\mathbf{5 2}$ and $\mathbf{5 3}$ (scheme 2.12). Separation of the two stereoisomers was attempted, unsuccessfully, therefore the assignment of the stereochemistry was not facile via NMR. However, NMR data indicated the major isomer, which was assumed to be $\mathbf{5 2}$ on the basis of steric arguments, was in approximately a 9:1 ratio to the minor isomer 53. These results were consistent with those reported by Risseeuw and colleagues ${ }^{104}$ in which separation of the two stereoisomers was not achieved until after the selective deprotection of the C-6 protecting group. 


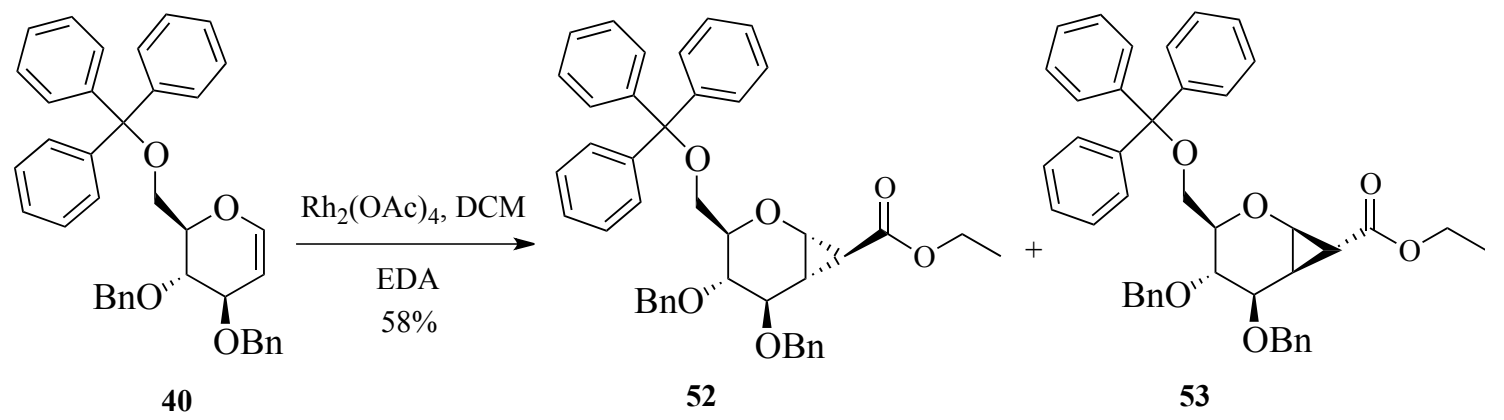

Scheme 2.12: Optimised synthesis of $\mathbf{5 2}$ and 53, leading to an inseparable mixture of both stereoisomers as reported by Risseeuw and colleagues. ${ }^{104}$

Utilising the aforementioned optimised C-6 trityl deprotection conditions (scheme 2.7), ${ }^{2}$ detritylation of compounds $\mathbf{5 2}$ and $\mathbf{5 3}$ was achieved with minimal formation of the formate ester by-product (scheme 2.13). Due to the low yields of the formate ester by-product, no formate of the minor isomer was detected. Deprotection of the trityl group allowed for the separation of the stereoisomers through silica gel column chromatography utilising a slow gradient elution of hexane:ethyl acetate of 14:1 to $1: 1(\mathrm{v}: \mathrm{v})$, and allowing for the isolation of the major product in a pleasing $61 \%$ yield (scheme 2.13).
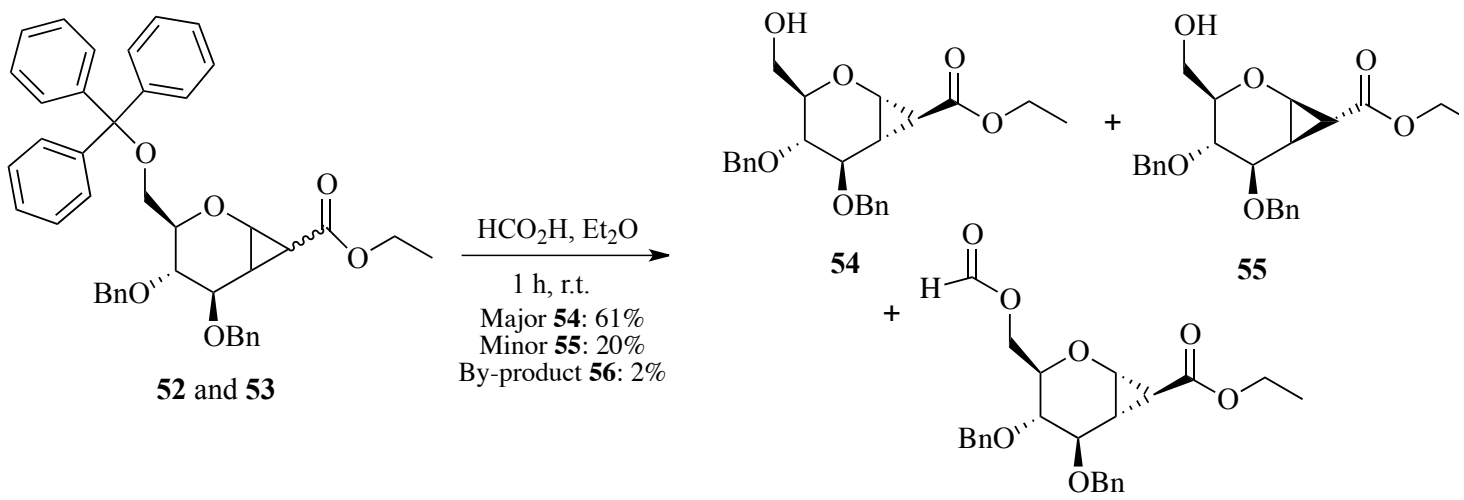

56

Scheme 2.13: Deprotection of the trityl group of the inseparable mixture of stereoisomers $\mathbf{5 2}$ and $\mathbf{5 3}$, affording 54, 55, and $\mathbf{5 6}$. 
HMBC spectroscopy along with correlated 1D and 2D NMR spectroscopy data were used to confirm the formation of the cyclopropane moiety through the interaction between the carbene and the alkene (figure 2.1). As shown in figure 2.1, coupling of both $\mathrm{H}-2$ and $\mathrm{H}-3$ to $\mathrm{C}-7$ indicates the successful addition of the carbene to the glucal alkene.

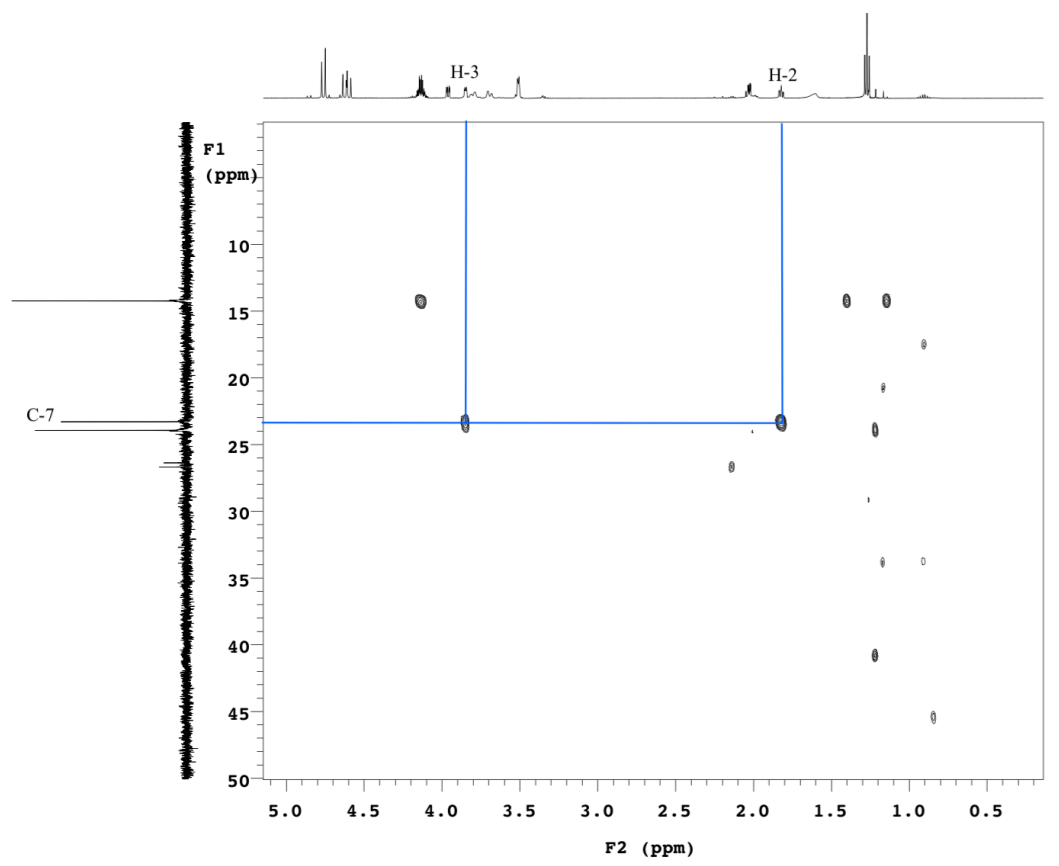

Figure 2.1: HMBC coupling of $54\left(\mathrm{CDCl}_{3}\right)$ showing the interactions of $\mathrm{H}-2$ and $\mathrm{H}-3$ with $\mathrm{C}-7$, indicating a successful cyclopropanation.

Although the $\alpha$-product $\mathbf{5 2}$ being the major product was consistent with the hypothesis that carbine addition to the $\alpha$-face would be more favourable due to the steric hindrance of the pseudo-axial protecting groups on C-6 and C-3, and the opposite being true for the minor product 53, it was deemed prudent to confirm this via computational modelling of both compounds. To this end, lowest energy conformers of the diastereomeric C-7 ethoxycarbonyl 1,2-cyclopropane carbohydrates 54 and $\mathbf{5 5}$, differing in the configuration at the ring fusion between $\mathrm{C}-1$ and $\mathrm{C}-2$, as well at $\mathrm{C}-7$, were determined by molecular mechanics. Each structure was subjected to exhaustive conformational searching using the mixed torsional/low mode sampling routine as implemented in MacroModel version 9.7 and visualised in Maestro 9.0. A minimum 
of 20,000 steps were applied. Structures obtained were minimised using the OPLS_2005 force field using the GB/SA chloroform continuum solvent model and the Polak-Ribiere conjugate gradient (PRCG) conjugate gradients method and terminated on a gradient threshold of $0.05 \mathrm{~kJ} \mathrm{~mol}^{-1} \mathrm{~A}^{\circ-1}$. The simulation was continued until the lowest energy structure reported had been replicated at least 50 times. The global minimum structure of major diastereomer $\mathbf{5 4}$ from this calculation was subjected to equilibrium geometry optimisation using the B3LYP hybrid density functional method 23, 24 and the $6-31 \mathrm{G}^{* *}$ basis set in Spartan '08, resulting in no differences in the key dihedral angles around the pyranose and cyclopropane rings. The lowest energy conformers for both $\mathbf{5 4}$ and $\mathbf{5 5}$ reported from the molecular modelling are presented in figure 2.2. From the molecular model, the dihedral angles around both the glucose derived ring and the cyclopropane ring were obtained, allowing for the calculation of the expected coupling constants. The dihedral angles obtained from the molecular modeling are shown in table 2.1

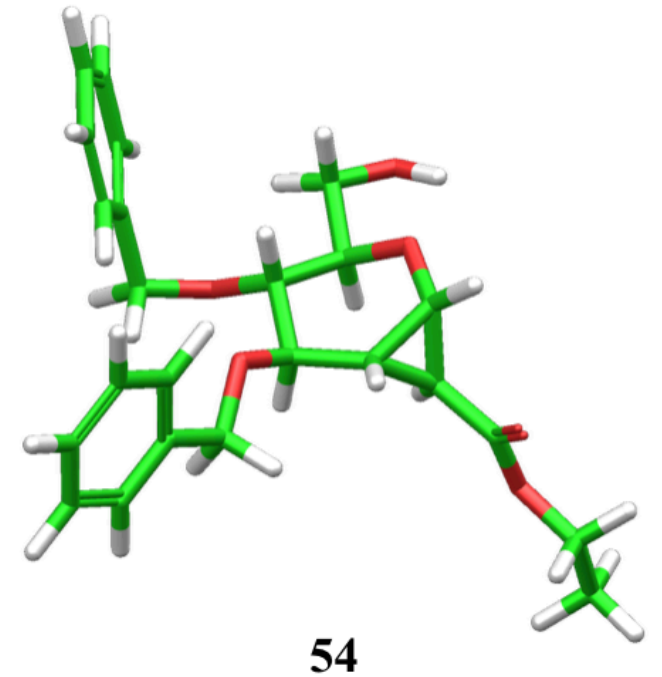

54

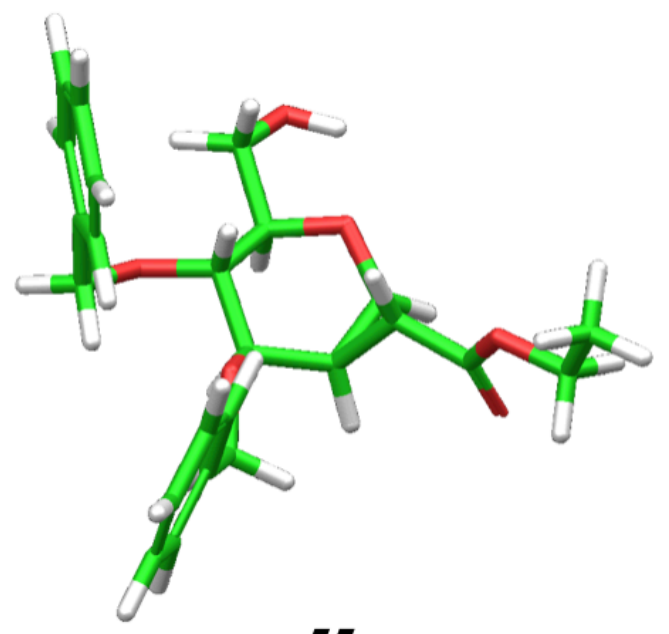

55

Figure 2.2: Lowest energy conformations of $\mathbf{5 4}$ and $\mathbf{5 5 .}$

\begin{tabular}{|l|c|c|c|c|}
\hline \multicolumn{5}{|c|}{ Dihedral angles } \\
\hline & H-1, H-2 & H2, H-3 & H-1, H-7 & H-2, H-7 \\
\hline Compound 54 & 2.7 & 104.5 & 143.8 & 146.6 \\
\hline Compound 55 & 4.5 & 34.3 & 143.3 & 146.5 \\
\hline
\end{tabular}

Table 2.1: Calculated dihedral angle of compound $\mathbf{5 4}$ and $\mathbf{5 5}$ utilising MacroModel version 9.7. 
From the calculated dihedral angles, predicted coupling constants were then obtained for the lowest energy conformers through the utilisation of a modified Karplus equation proposed by Haasnoot ${ }^{106}$ and implemented by Sweet $\mathrm{J}$ computer program. ${ }^{107,107 \mathrm{~b}}$ As shown in table 2.2, the comparison of the calculated coupling constants and the measured coupling constants show a reasonable correlation. Deviation away from the measured coupling constants is most likely to be due to the strain of the cyclopropane ring.

\begin{tabular}{|l|c|c|c|c|}
\hline \multicolumn{5}{|c|}{ Calculated coupling constants } \\
\hline & $\mathrm{H}-1, \mathrm{H}-2$ & $\mathrm{H} 2, \mathrm{H}-3$ & $\mathrm{H}-1, \mathrm{H}-7$ & $\mathrm{H}-2, \mathrm{H}-7$ \\
\hline Compound $\mathbf{5 4}$ & $7.42 \mathrm{~Hz}$ & $0.90 \mathrm{~Hz}$ & $6.95 \mathrm{~Hz}$ & $9.44 \mathrm{~Hz}$ \\
\hline Compound $\mathbf{5 5}$ & $7.39 \mathrm{~Hz}$ & $7.34 \mathrm{~Hz}$ & $6.75 \mathrm{~Hz}$ & $9.44 \mathrm{~Hz}$ \\
\hline
\end{tabular}

\begin{tabular}{|l|c|c|c|c|}
\hline \multicolumn{5}{|c|}{ Measured coupling constants } \\
\hline & $\mathrm{H}-1, \mathrm{H}-2$ & $\mathrm{H} 2, \mathrm{H}-3$ & $\mathrm{H}-1, \mathrm{H}-7$ & $\mathrm{H}-2, \mathrm{H}-7$ \\
\hline Compound $\mathbf{5 4}$ & $7.25 \mathrm{~Hz}$ & $0 \mathrm{~Hz}$ & $2.25 \mathrm{~Hz}$ & $6.25 \mathrm{~Hz}$ \\
\hline Compound $\mathbf{5 5}$ & $2.5 \mathrm{~Hz}$ & $5 \mathrm{~Hz}$ & $6.5 \mathrm{~Hz}$ & $9.5 \mathrm{~Hz}$ \\
\hline
\end{tabular}

Table 2.2: Calculated coupling constants generated by Sweet J from the dihedral angle obtain from MacroModel version 9.7 compared to the measured coupling constants of compound $\mathbf{5 4}$ and $\mathbf{5 5}$.

Due to the deviation of the measured coupling constant away from the calculated coupling constant of the H-1, H-7 coupling on $\mathbf{5 4}$ and H-1, H-2 coupling on 55, NOE analyses of both compounds $\mathbf{5 4}$ and $\mathbf{5 5}$ were undertaken to provide further weight to the stereochemical assignment. NOE analysis of compound $\mathbf{5 4}$ through the irradiation of $\mathrm{H}-7$ showed the interactions between $\mathrm{H}-7$ with $\mathrm{H}-5$ and $\mathrm{H}-3$, which confirmed that the addition of the carbene had occurred from the $\alpha$-face of the alkene with the carboxyethyl group in the exo-position to the $\mathrm{C}-3$ and $\mathrm{C}-2$ hydrogen (figure 2.3A). Irradiation of proton $\mathrm{H}-2$ of compound $\mathbf{5 5}$ also showed its interactions with $\mathrm{H}-5$, which confirmed the addition of the carbene from the $\beta$-face of the alkene as predicted by molecular modeling (figure 2.3B). 


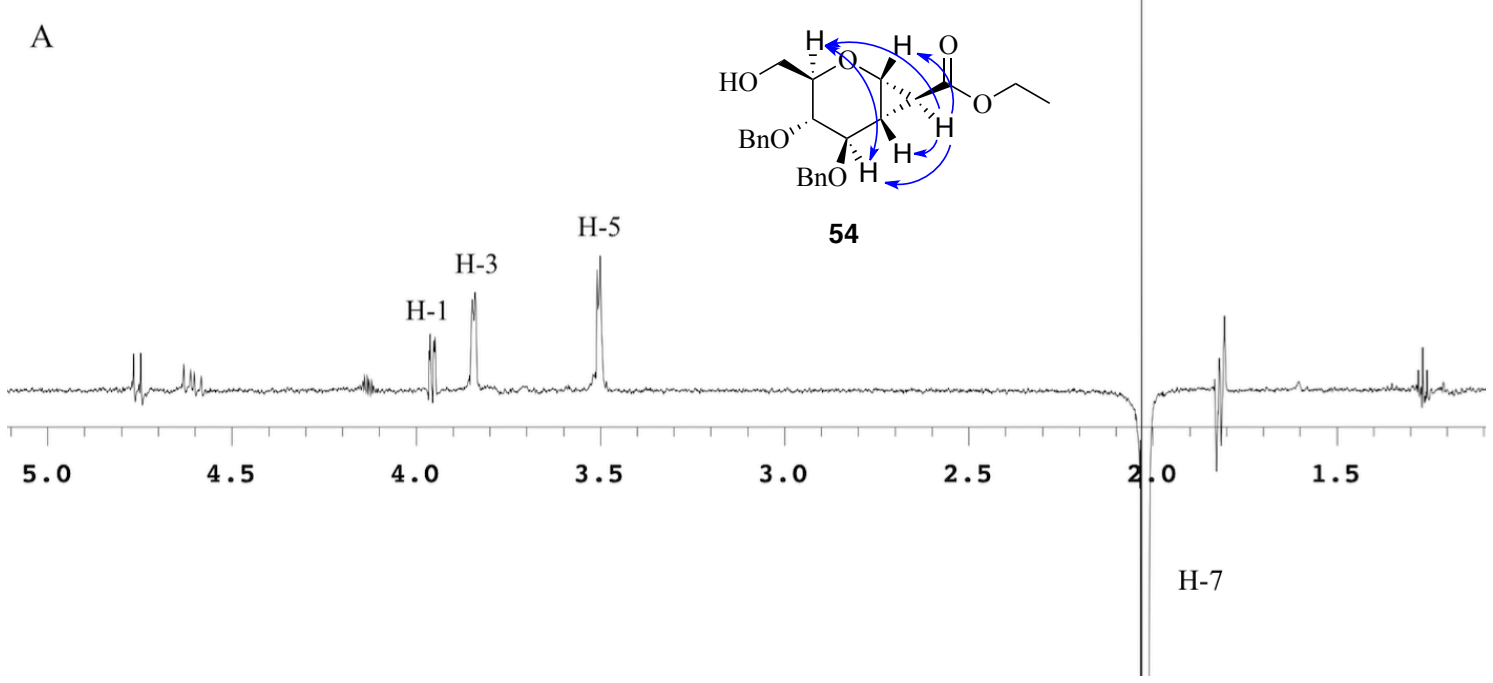

Figure 2.3: A) NOE of 54, irradiation at H-7, NOE correlations shown on compound 54.

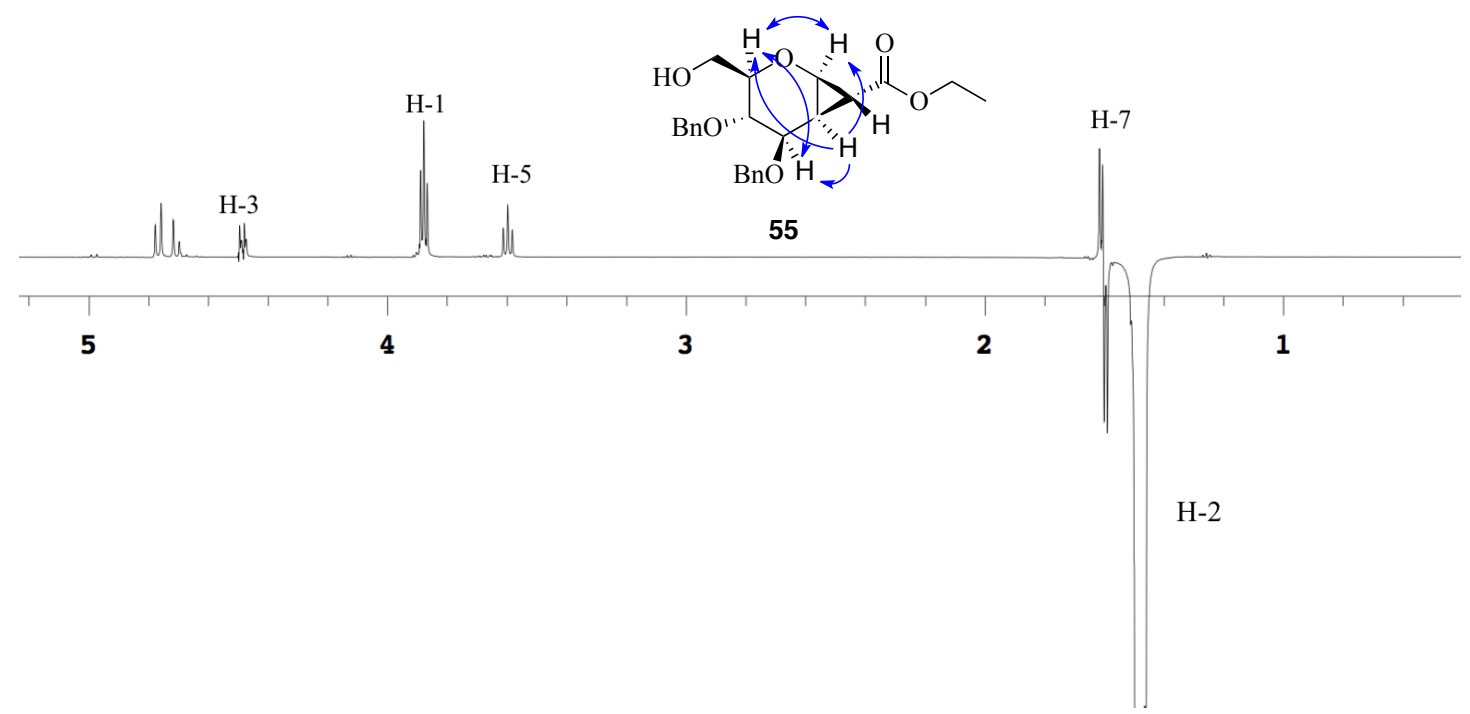

Figure 2.3: B) NOE of 55, irradiation at H-2, NOE correlations shown on compound $\mathbf{5 5 .}$

Full characterisations of compounds 54 and 55 were thus achieved using a combination of both 1D and 2D NMR data, along with molecular modelling and NOE correlations. This allowed for parallel identification of the stereochemistry of both the cyclopropane and the carboxyethyl groups. 


\subsection{Synthesis of the propargyloxycarbonyl substituted 1,2- cyclopropyl carbohydrates 61 and 62.}

Due to the successfully optimised methodology used in the synthesis of the ethoxycarbonyl substituted 1,2-cyclopropyl carbohydrates 54 and 55, a similar synthetic route was proposed for the synthesis of propargyloxycarbonyl 1,2cyclopropyl carbohydrates $\mathbf{6 1}$ and $\mathbf{6 2}$. As with the synthesis of the ethyl diazoacetate, initial synthesis of propargyl glycinate hydrochloride was first targeted. This was undertaken through a Fischer esterification of propargyl alcohol with glycine utilising acetyl chloride as a precursor for the in situ formation of $\mathrm{HCl}$ as proposed by Patnaik and colleagues (scheme 2.14). ${ }^{93}$ However this resulted in a black viscous solution, which after several attempts at purification yielded no product. The formation of a black by-product was thought to be due to a side reaction with acetyl chloride resulting in polymerisation of the propargyl alcohol. Accordingly, an alternative method reported by Ramapanicker and colleagues ${ }^{108}$ was then employed in which they state that no black by-product formed. Their methodology involves first bubbling $\mathrm{HCl}$ gas through cold propargyl alcohol to provide a saturated $\mathrm{HCl}$ solution before the addition of glycine. $\mathrm{HCl}$ gas was readily synthesised via the dropwise addition of concentrated sulfuric acid onto $\mathrm{NaCl}$ and, once formed, was then bubbled through concentrated sulfuric acid in order to remove any water before bubbling though the propargyl alcohol. However this methodology, also disappointingly, led to the formation of the black by-product. Purification of the resulting black solution was again unsuccessful and no product was isolated (scheme 2.14).

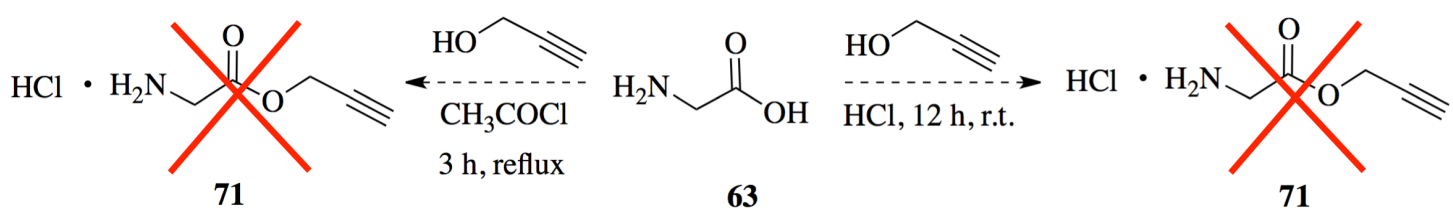

Scheme 2.14: Unsuccessful syntheses of propargyl glycinate hydrochloride utilising methodology proposed by both Patnaik and colleagues ${ }^{93}$ and Ramapanicker and colleagues. ${ }^{108}$ 
Due to the unsuccessful synthesis of propargyl glycinate hydrochloride, a new synthetic strategy for propargyl diazoacetate that by-passed the propargyl glycinate hydrochloride altogether was required. A method first reported by Fukuyama and colleagues $^{109}$ was selected due to its high yielding synthesis of propargyl diazoacetate and its reduced explosive characteristics. This method involved a two-step process: formation of propargyl bromoacetate, followed by a diazo-transfer reaction with $N, N$-ditosylhydrazine (57). ${ }^{109}$ The synthesis of $N, N$-ditosylhydrazine (57) was undertaken through a nucleophilic attack by the primary amine of $p$-toluenesulfonyl hydrazide on $p$-toluenesulfonyl chloride $(\mathrm{TsCl})$. After recrystallisation, this led to very favourable $81 \%$ yield of $\mathbf{5 7}$ (scheme 2.15 ).

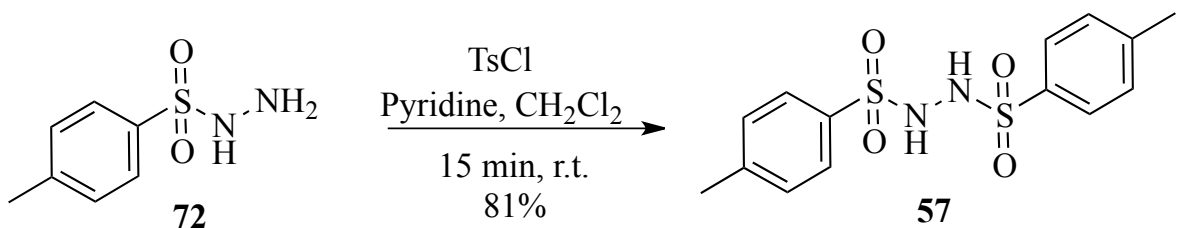

1) Bromoacetyl bromide (74),

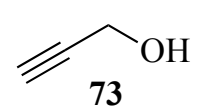

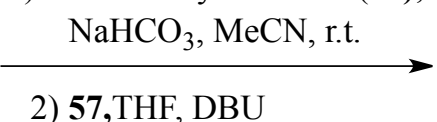

$57 \%$

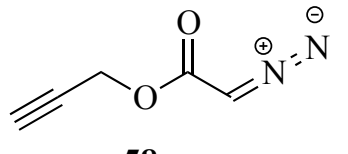

58

Scheme 2.15: Synthesis of $\mathbf{5 7}$ and $\mathbf{5 8 .}$

As stated by Fukuyama and colleagues $N, N$-ditosylhydrazine proved to be a useful reagent due to its ease of handling, thermal stability and shelf stability. ${ }^{109,97 a}$ With hydrazine $\mathbf{5 7}$ in hand, the two-step synthesis of the desired diazoacetate $\mathbf{5 8}$ was undertaken. Initial treatment of propargyl alcohol (73) with bromoacetyl bromide (74) led to the formation of propargyl bromoacetate (75) via an esterification reaction (scheme 2.16). Without further purification, the resulting ester $\mathbf{7 5}$ was subjected to a substitution reaction through nucleophilic attack by the hydrazine $\mathbf{5 7}$ in the presence of the bulky base 1,8-diazobicycloundec-7-ene (DBU). This led to the double elimination of toluenesulfinic acid (78) resulting in the final propargyl diazoacetate 48 
(58) as a orange oil in a $57 \%$ yield after purification. A proposed mechanism for the formation of $\mathbf{5 8}$ is presented in scheme 2.16 in which double elimination of the toluenesulfinic acid proceeds through the formation of the nitrene species $\mathbf{8 0}$. Moderate yields are typical due to the volatile nature of $\mathbf{5 8}$ as noted by Fukuyama and colleagues. $^{109}$

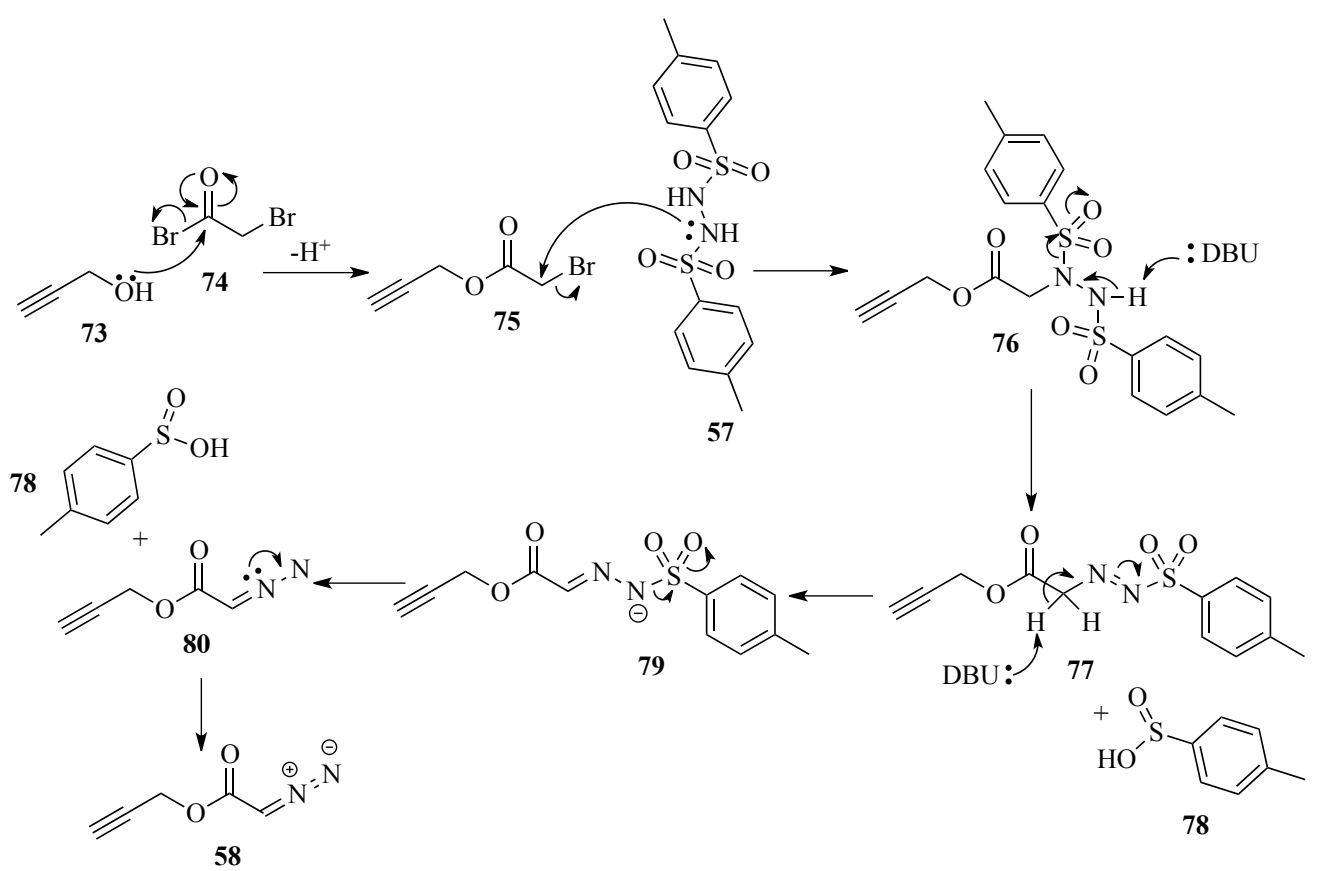

Scheme 2.16: Proposed mechanism of the synthesis of $\mathbf{5 8}$ noting two-fold elimination of toluenesulfinic acid.

Cyclopropanation of the glucal $\mathbf{4 0}$ with the diazoacetate $\mathbf{5 8}$ followed the same optimised procedure as with previous diazoacetates (see scheme 2.12), in which a solution of rhodium acetate and glucal $\mathbf{4 0}$ in dichloromethane were treated with a solution of 58 in dichloromethane over 14 hours under an argon atmosphere. As mentioned, addition over 14 hours reduced both the undesired formation of fumarates and amount of starting material recovered. Silica gel flash column chromatography was used in an attempt to purify the crude material, utilising both hexanes:ethyl acetate and toluene:ethyl acetate solvent systems, however, although purification was successful, separation of the stereoisomers was not achieved and an inseparable mixture of both stereoisomers $\mathbf{5 9}$ and $\mathbf{6 0}$ were isolated in a $38 \%$ yield (scheme 2.17). Therefore the stereochemistry of the two isomers could not yet be established, 
however, it was predicted that the major isomer would result from the stericallydirected addition of the carbenoid to the $\alpha$-face of the alkene, as seen in the synthesis of the ethyl derivatives $\mathbf{5 4}$ and $\mathbf{5 5}$. Despite the inability to separate the stereoisomers, ${ }^{1} \mathrm{H}$ NMR data indicated the presence of the stereoisomers in a 5:1 ratio. The slightly reduced yield compared to the ethoxycarbonyl derivatives $\mathbf{5 4}$ and 55 was thought to be due to partial quenching of the carbenoid by the alkyne. Carbene addition to terminal alkynes undergoing a $\mathrm{C}-\mathrm{H}$ insertion or cyclopropene formation is precedented in the literature ${ }^{110,111}$ when catalysed by organometallic complexes such as rhodium acetate. ${ }^{112}$

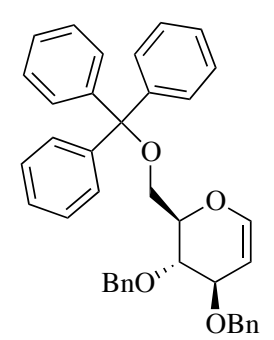

40

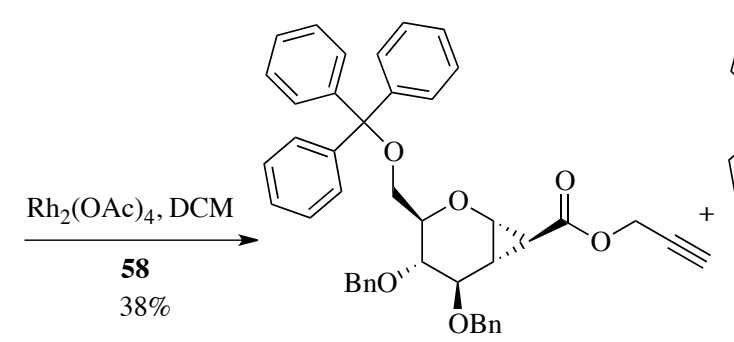

59

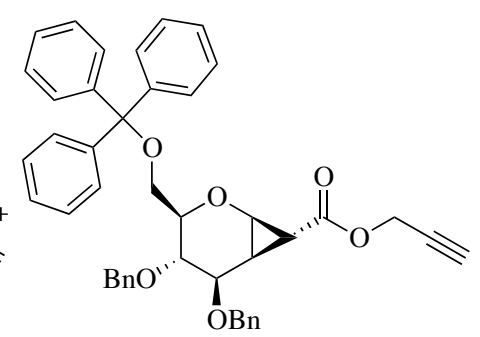

60

Scheme 2.17: Cyclopropanation of $\mathbf{4 0}$ with $\mathbf{5 8}$ forming an inseparable mixture of stereoisomers $\mathbf{5 9}$ and 60.

As with the separation of the stereoisomers $\mathbf{5 2}$ and $\mathbf{5 3}$ (scheme 2.13) it was expected that separation of both $\mathbf{5 9}$ and $\mathbf{6 0}$ would be possible upon removal of the C-6 trityl protecting group. The optimised conditions developed in the selective deprotection of the dichlorocyclopropyl derivative $\mathbf{4 1}$ were again utilised in order to reduce the formation of the formate ester by-product. To this end, the mixture of stereoisomers 59 and 60 was treated with formic acid and the reaction quenched after 50 minutes based on closely following the reaction progress by TLC. As stated previously, optimisation of the proposed workup by Nagarajan and colleagues ${ }^{68}$ was undertaken through the addition of $\mathrm{NaHCO}_{3}$, as concentration of the reaction mixture before quenching led to the perfect conditions for undesired ester formation. ${ }^{59}$ Separation of the resulting deprotected stereoisomers $\mathbf{6 1}$ and $\mathbf{6 2}$ proved to be difficult as separation by silica column chromatography utilising both hexanes:ethyl acetate and 
toluene:ethyl acetate solvent systems were unsuccessful. The exploration of many different solvent systems to separate the two isomers on TLC seemed futile, however using dichloromethane:ethyl acetate solvent system showed a small amount of promise. A long silica gel column utilising a slow gradient elution of 100:1 $\rightarrow$ 3:1 dichloromethane:ethyl acetate (v:v) was successful, yielding 61 and 62 in a $43 \%$ and $10 \%$ yield, respectively (scheme 2.18 ).

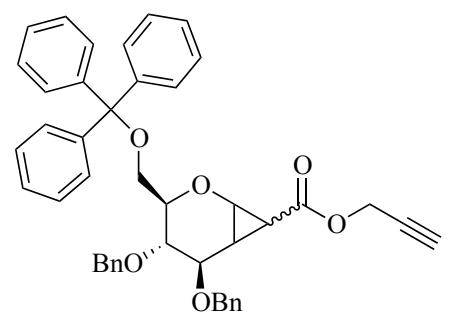

59 and 60

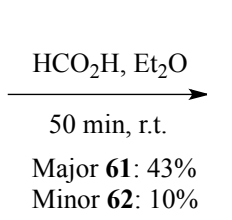

Major 61: $43 \%$
Minor 62: $10 \%$

(1)

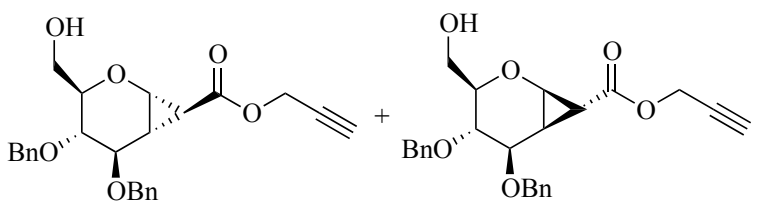

61

62

Scheme 2.18: Detritylation of the C-6 trityl and separation of stereoisomers 61 and 62.

With the successful separation of $\mathbf{6 1}$ and $\mathbf{6 2}, \mathrm{HMBC}$ data were then obtained and the outcomes of the cyclopropanation reactions were confirmed. As shown in figure 2.4, analysis of the HMBC spectrum revealed interactions between $\mathrm{H}-2$ and C-7, H-3 and C-7, as well as H-7 and C-2 for compound 61. Figure 2.5 shows the interactions between $\mathrm{H}-2$ and $\mathrm{H}-3$ to $\mathrm{C}-7$ as well as $\mathrm{H}-7$ to $\mathrm{C}-2$ exhibited in the HMBC spectrum of 62 . 


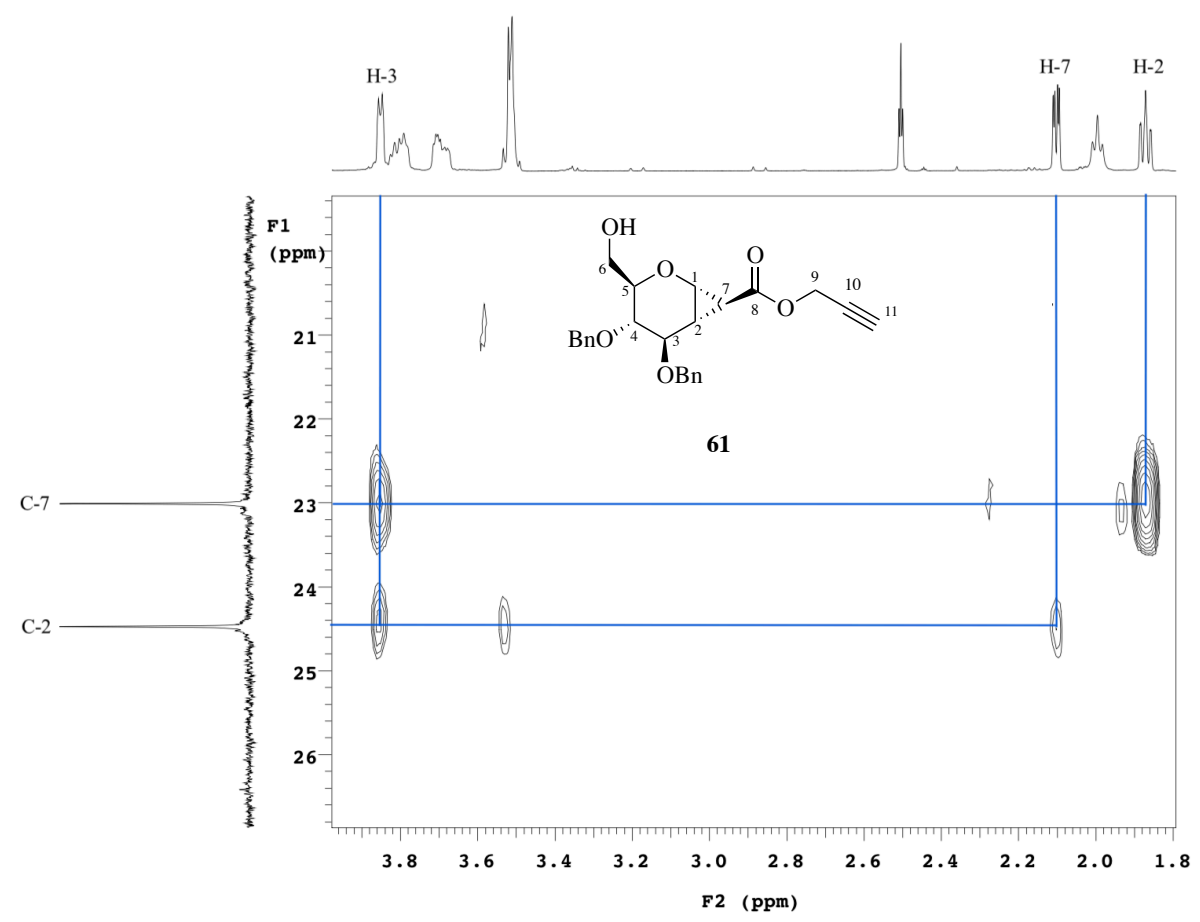

Figure 2.4: HMBC spectrum of $\mathbf{6 1}$ showing coupling between $\mathrm{H}-2$ and $\mathrm{H}-3$ to $\mathrm{C}-7$ along with $\mathrm{H}-7$ to C-2.

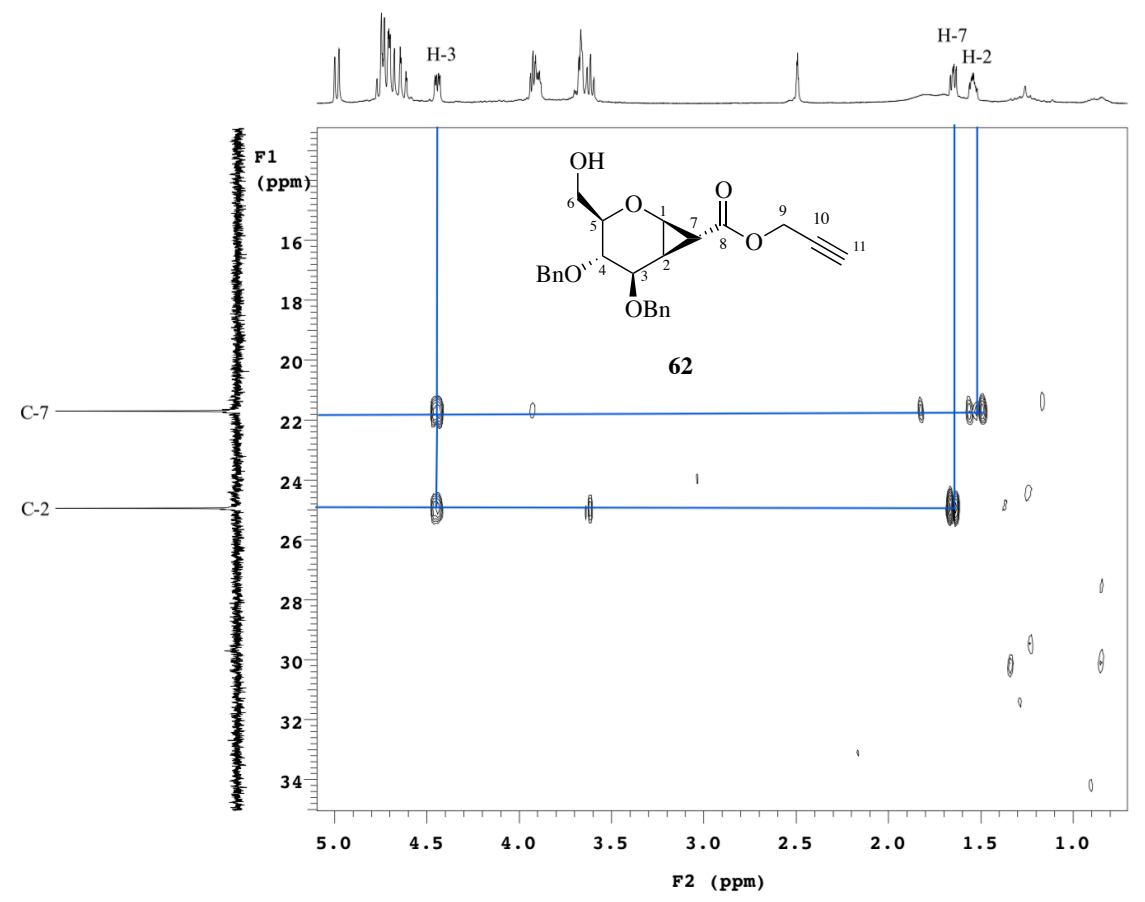

Figure 2.5: HMBC spectrum of $\mathbf{6 2}$ confirming showing between $\mathrm{H}-2$ and $\mathrm{H}-3$ to $\mathrm{C}-7$ as well as H-7 to $\mathrm{C}-2$. 
The challenge of determining the stereochemistry was again undertaken in a similar manner to that used for compounds 54 and $\mathbf{5 5}$. As per compounds 54 and 55, the same methodology utilising the molecular modelling systems with MacroModel version 9.7 was applied in order to identify the lowest energy conformations of both 61 and 62 . The calculated dihedral angles are shown in table 2.3. The dihedral angles determined for compounds 61 and 62 were the same as those reported for compounds 54 and $\mathbf{5 5}$, as shown in table 2.3 .

\begin{tabular}{|l|c|c|c|c|}
\hline \multicolumn{5}{|c|}{ Dihedral angles (degrees) } \\
\hline & $\mathrm{H}-1, \mathrm{H}-2$ & $\mathrm{H} 2, \mathrm{H}-3$ & $\mathrm{H}-1, \mathrm{H}-7$ & $\mathrm{H}-2, \mathrm{H}-7$ \\
\hline Compound 61 & 2.7 & 104.5 & 143.8 & 146.6 \\
\hline Compound 62 & 4.5 & 34.3 & 143.3 & 146.5 \\
\hline
\end{tabular}

Table 2.3: Calculated dihedral angle of the lowest energy conformers of $\mathbf{6 1}$ and $\mathbf{6 2}$ as modelled by MacroModel.

The measured and calculated coupling constants are shown in table 2.4. Reasonable correlations were observed as shown in table 2.4, though not without discrepancies, which may be due to the steric strain applied by the cyclopropane ring affecting the position of the Karplus curve.

\begin{tabular}{|c|c|c|c|c|}
\hline \multicolumn{5}{|c|}{ Calculated coupling constants } \\
\hline & $\mathrm{H}-1, \mathrm{H}-2$ & $\mathrm{H} 2, \mathrm{H}-3$ & $\mathrm{H}-1, \mathrm{H}-7$ & $\mathrm{H}-2, \mathrm{H}-7$ \\
\hline Compound 61 & $7.42 \mathrm{~Hz}$ & $0.90 \mathrm{~Hz}$ & $6.95 \mathrm{~Hz}$ & $9.44 \mathrm{~Hz}$ \\
\hline Compound 62 & $7.39 \mathrm{~Hz}$ & $7.34 \mathrm{~Hz}$ & $6.75 \mathrm{~Hz}$ & $9.44 \mathrm{~Hz}$ \\
\hline \multicolumn{5}{|c|}{ Measured coupling constants } \\
\hline & $\mathrm{H}-1, \mathrm{H}-2$ & $\mathrm{H} 2, \mathrm{H}-3$ & $\mathrm{H}-1, \mathrm{H}-7$ & $\mathrm{H}-2, \mathrm{H}-7$ \\
\hline Compound 61 & $7.25 \mathrm{~Hz}$ & $0 \mathrm{~Hz}$ & $2.5 \mathrm{~Hz}$ & $6.5 \mathrm{~Hz}$ \\
\hline Compound 62 & $4 \mathrm{~Hz}$ & $4 \mathrm{~Hz}$ & $9.25 \mathrm{~Hz}$ & $6.75 \mathrm{~Hz}$ \\
\hline
\end{tabular}

Table 2.4: Comparison of the calculated and measured coupling constants of 61 and 62.

Again NOE analyses of both compounds $\mathbf{6 1}$ and $\mathbf{6 2}$ were undertaken to further confirm the stereochemistry of the two diastereoisomers (figures 2.6 and 2.7). For 
compound 61, irradiation of H-7 indicated clear coupling interactions of H-7 with both H-3 and H-5, indicating that the cyclopropane ring is $\alpha$ to the pyranose ring and carboxyalkyl substituent is in the exo position (figure 2.6). Irradiation of H-7 in 62 resulted in the coupling of $\mathrm{H}-7$ solely with $\mathrm{H}-4$ indicating the $\beta$-exo configuration of the cyclopropane and carboxyalkyl group (figure 2.7). The results are consistent with the lowest energy configuration calculated by the molecular modelling.

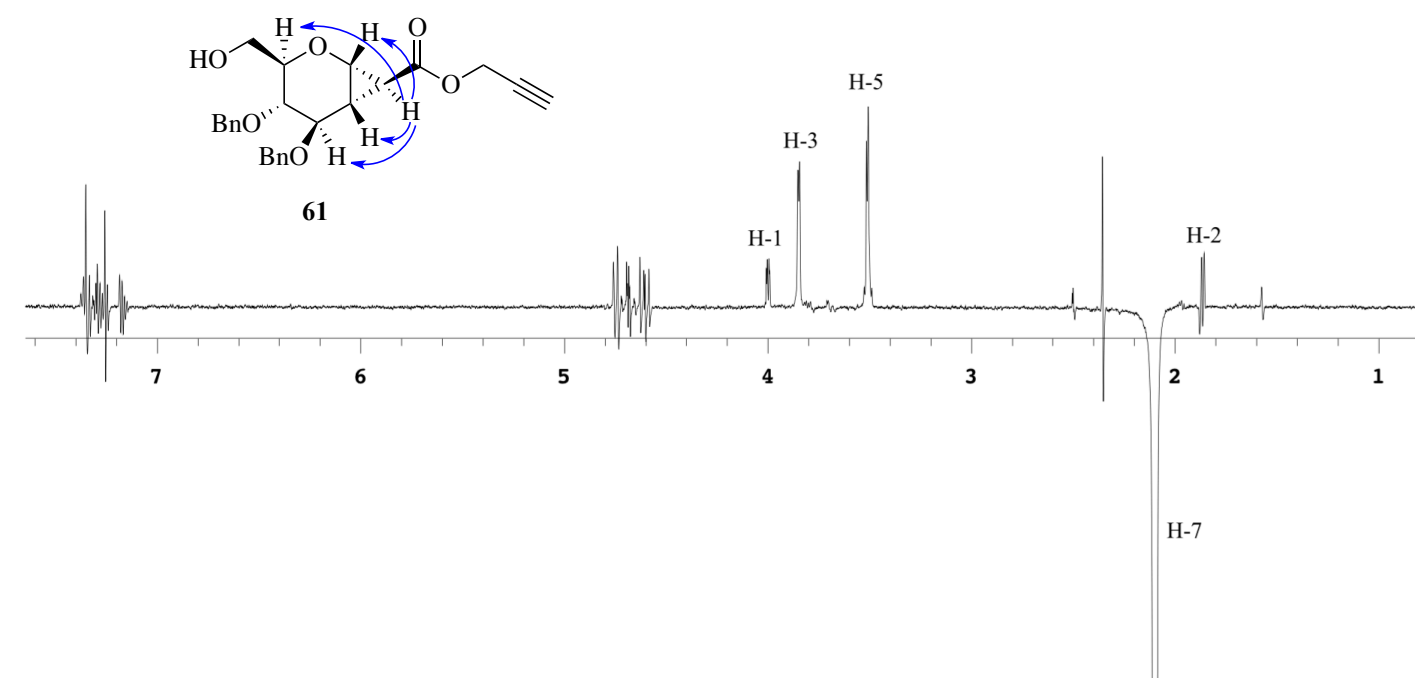

Figure 2.6: NOE analysis of the stereoisomer $\mathbf{6 1}$ with irradiation at H-7.

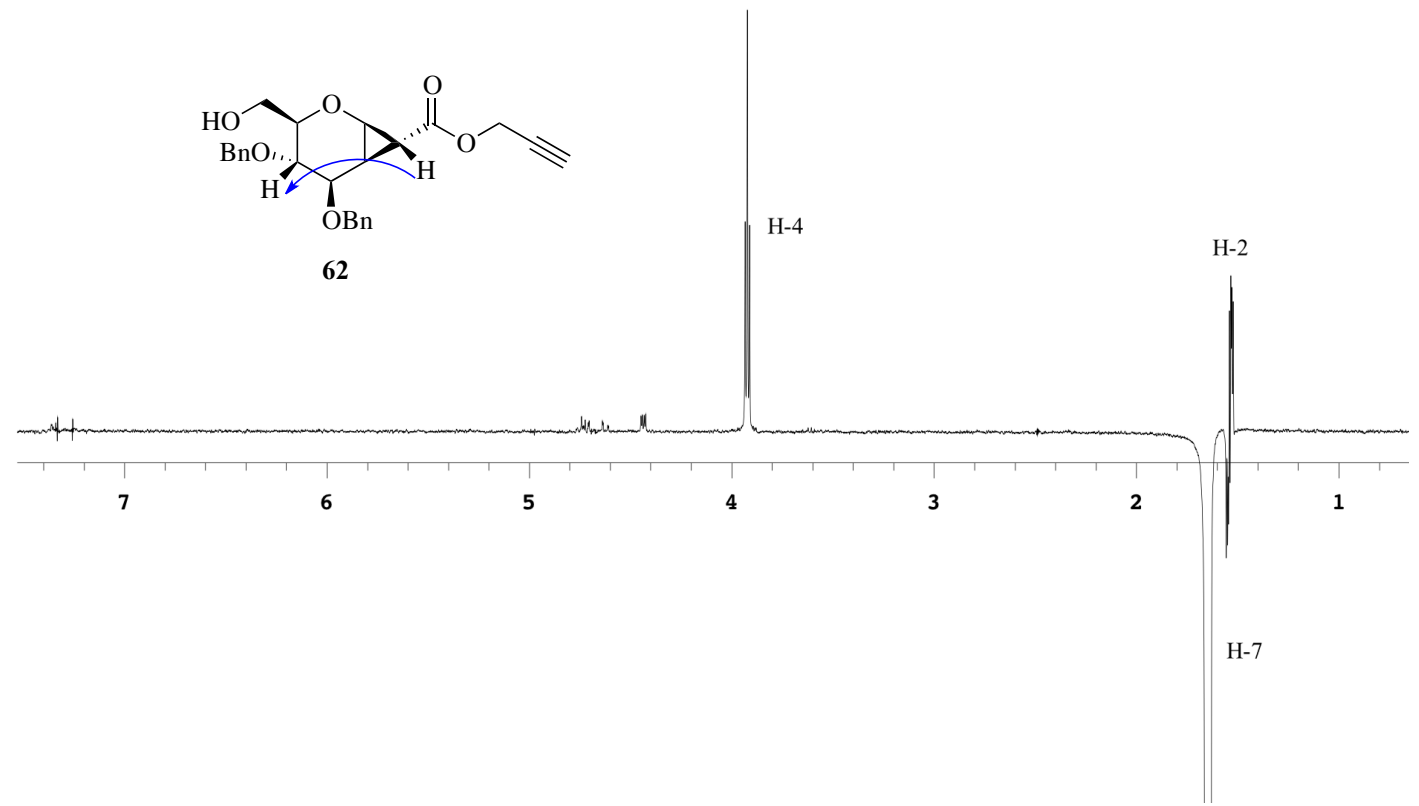

Figure 2.7: NOE analysis of the stereoisomer $\mathbf{6 2}$ with irradiation at H-7. 
Due to the similarities in both molecular modelling and the NOE results, the lowest energy structures of compounds $\mathbf{6 1}$ and $\mathbf{6 2}$ were visually overlaid in the Spartan software with compounds $\mathbf{5 4}$ and $\mathbf{5 5}$ to allow for comparison of their conformation. As shown in figure 2.8, the structures overlay very closely in both cases. The deviation of the C-3 benzyl group, seen in figure 2.8A, has a low barrier of activation to the requisite bond rotation. The corresponding propargyl conformation in which the C-3 benzyl group overlays the ethyl conformer is within $1 \mathrm{~kJ} / \mathrm{mol}$. This reflects the flexibility of the benzyl substituents under ambient temperatures.

A)

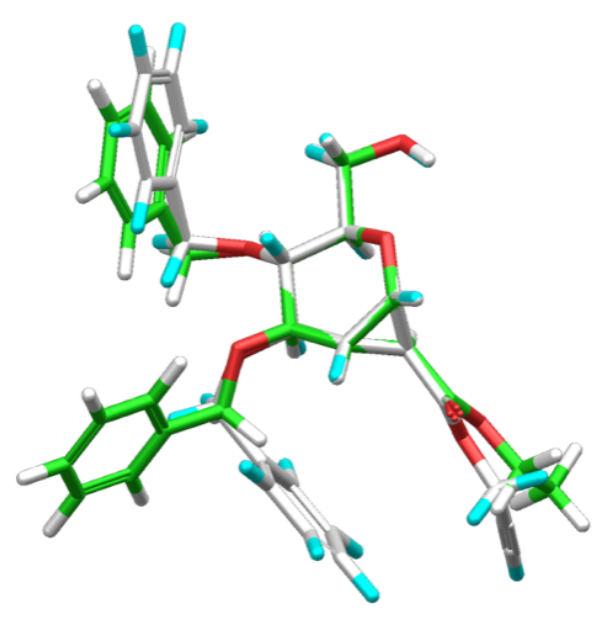

B)

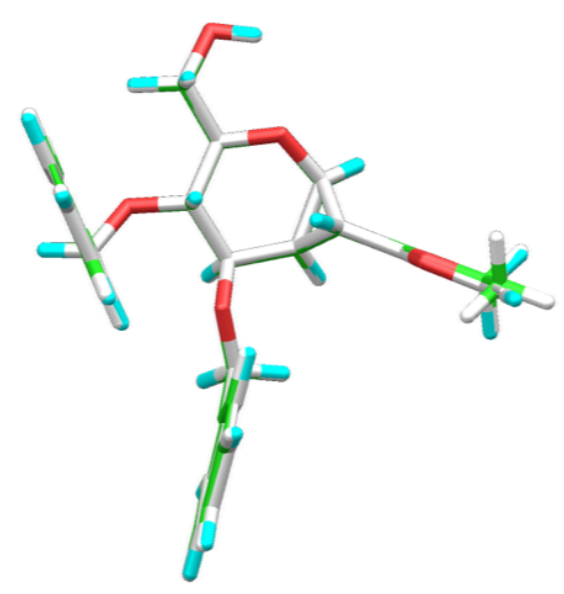

Figure 2.8: Lowest energy conformers of A) 54 and 61, B) 55 and 62. Compounds 54 and 55 are indicated in green and red, and compounds $\mathbf{6 1}$ and $\mathbf{6 2}$ are shown in white and blue.

\section{Summary}

Synthesis of the final products $\mathbf{6 1}$ and $\mathbf{6 2}$ concluded the chemical aspect of this thesis, which included the successful syntheses of the target 1,2-cyclopropyl carbohydrates derivatives 23, 54, 55 and 56. Development of new methodologies and optimisation of reported literature procedures have led to a high yielding synthetic route to 1,2cyclopropyl carbohydrates. Synthesis of compound $\mathbf{2 3}$ was achieved over 7 steps at a modest overall yield of $32 \%$. Similar results were obtained for the carboxyalkyl 
derivatives with the isomeric mixtures of 54 and 55, and 61 and 62 being achieved in overall yields of $22 \%$ and $9 \%$ respectively over 7 steps. The exploration of a new C-6 TBDPSCl protecting groups was undertaken, however due to low yields and lack of reagent, optimisation of the current trityl protection procedure was the preferred route. This led to very pleasing results during deprotection, leading to a $15 \%$ reduction of the formate by-product compared to previously reported syntheses. ${ }^{2}$ All stereochemistry was determined through the use of molecular modeling, analysis of coupling constants and NOE spectroscopy. The target compounds $23,54,55,56,61$ and 62 will now be subjected to biological analysis to assess their bioactivity. The compounds will be screen against a yeast deletion library in order to identify chemical genetic interactions and elucidate a potential mechanism of action. 


\section{Experimental}

\subsection{General experimental}

Unless otherwise stated, all reactions were conducted under nitrogen atmosphere in oven-dried glassware using HPLC grade solvents. $\mathrm{CH}_{2} \mathrm{Cl}_{2}, \mathrm{Et}_{2} \mathrm{O}$ and THF were obtained from the PureSolv (Innotive Technologies). Hexanes, ethanol, methanol, ethyl acetate, toluene (Ficher Scientific) and chloroform (Vickers Laboratory) were of HPLC grade and used for reactions and column chromatography as received. DMF (Acros Organics) was stored over molecular sieves. Perchloric acid (Sigma-Aldrich), formic acid (BDH biochemical), D-Glucose (Sigma-Aldrich), NaH (Sigma-Aldrich), TBAI (Honeywell Riedal-de Haën), BnBr (Sigma-Aldrich), TEBAC (Sigma-Aldrich), glycine (BDH bioscience), $\mathrm{RhCl}_{2} \cdot 3 \mathrm{H}_{2} \mathrm{O}$ (Merck \& Co.), $\mathrm{NaAc} \cdot 3 \mathrm{H}_{2} \mathrm{O}$ (Univar), $p$ toluenesulfonyl hydrazine (Sigma-Aldrich), $p$-toluenesulfonyl chloride (SigmaAldrich), propargyl alcohol (Sigma-Aldrich), bromoacetyl bromide (Sigma-Aldrich), and DBU (Merck \& Co.) were all used as received. Concentration of solvents in vacuo was achieved through the use of a rotary evaporator fitted to a vacuum pump in a water bath of $40^{\circ} \mathrm{C}$.

Reaction progress was monitored using TLC (thin layer chromatography) plates precoated in silica DC-Fertigfolien Polygram ${ }^{\circledR}$ SIL G/UV 254 and visualised by dipping in potassium permanganate in water, anisaldehyde, and phospomolybdic acid, as well as detection by UV absorption ( $254 \mathrm{~nm}$ ). Purification of products was achieved using flash column chromatography. Columns were packed using silica 60 (Pure Science Silica Gel, 40-60 microns) as the stationary phase, using the solvent system indicated. ${ }^{1} \mathrm{H}$ NMR and ${ }^{13} \mathrm{C}$ NMR spectra were recorded on a Varian Unity Inova 500 (operating at $500 \mathrm{MHz}$ for ${ }^{1} \mathrm{H}$ and $125 \mathrm{MHz}$ for ${ }^{13} \mathrm{C}$ ) spectrometer, NOSEY spectra were recorded on Varian Directed Drive instrument equipped with an inverse-detected triple resonance $\mathrm{HCN}$ probe operating at $25^{\circ} \mathrm{C}\left(600 \mathrm{MHz}\right.$ for $\left.{ }^{1} \mathrm{H}\right)$. All chemical shifts

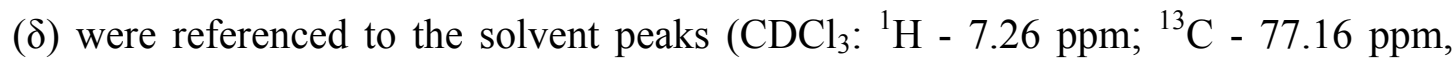
$\left.\left(\mathrm{CD}_{3}\right)_{2} \mathrm{SO}:{ }^{1} \mathrm{H}-2.50 \mathrm{ppm} ;{ }^{13} \mathrm{C}-39.52 \mathrm{ppm}, \mathrm{D}_{2} \mathrm{O}:{ }^{1} \mathrm{H}-4.79 \mathrm{ppm} ;\right) .{ }^{113} \mathrm{NMR}$ peaks were assigned based on COSY, HSQC and HMBC 2D experiments. Melting points were obtained using Gallenkamp melting point apparatus and are uncorrected. 
Infrared spectra was recorded using thin films on a Bruker Tensor 27 FTIR spectrometer outfitted with an Attenuated Total Reflactance (ATR) sampling accessory. Optical rotation measurements were recorded on a Rudolph research analytical Autopol II automatic polarimeter.

\subsection{Chemistry synthesis}

\section{Tri-O-acetyl-D-glucal (37)}<smiles></smiles>

37

Using a modification of the Kozikowski's procedure ${ }^{79}$, perchloric acid $(0.48 \mathrm{~mL}, 4.5 \mathrm{mmol})$ was added dropwise to a mechanically stirred solution of D-glucose ( $72 \mathrm{mg}, 0.4 \mathrm{mmol})$ in acetic anhydride (38.2 mL). Additional D-glucose (9.93 g, $55.1 \mathrm{mmol})$ was added over a period of 40 minutes at $45^{\circ} \mathrm{C}$, after which the reaction was allowed to cool to room temperature. The solution was then treated with a $33 \%(\mathrm{w} / \mathrm{w})$ solution of $\mathrm{HBr}$ in acetic acid $(39 \mathrm{~mL}$, $149 \mathrm{mmol}$ ) and left to stir for $1.5 \mathrm{~h}$. After TLC-analysis showed the disappearance of starting materials, the solution was diluted with $\mathrm{CH}_{2} \mathrm{Cl}_{2}(106 \mathrm{~mL})$. The organic layer was then extracted and washed with ice-cold $\mathrm{H}_{2} \mathrm{O}(3 \times 50 \mathrm{~mL})$, followed by sat. aq. $\mathrm{NaHCO}_{3}(6 \times 50 \mathrm{~mL})$ before it was dried over anhydrous $\mathrm{MgSO}_{4}$, which was removed by filtration. The filtrate was then concentrated in vacuo to give the crude tetra- $O$ acetyl-D-glucopyranosyl bromide as an off-white solid, which was used without further purification.

A mechanically stirred solution of zinc dust (24 g, $366.3 \mathrm{mmol})$ in $\mathrm{H}_{2} \mathrm{O}(76 \mathrm{~mL})$ was cooled to $0{ }^{\circ} \mathrm{C}$ before it was diluted with acetic acid $(76 \mathrm{~mL})$. The solution was then treated to a dropwise addition of the crude tetra- $O$-acetyl-D-glucopyranosyl bromide $(25.06 \mathrm{~g}, 61.1 \mathrm{mmol})$ in $\mathrm{Et}_{2} \mathrm{O}(76 \mathrm{~mL})$ over a period of $1 \mathrm{~h}$. The reaction was allowed to warm to room temperature and left to stir overnight. After TLC-analysis showed the disappearance of starting materials, the solution was filtered removing the zinc dust, then diluted with $\mathrm{CH}_{2} \mathrm{Cl}_{2}(110 \mathrm{~mL})$. The organic layer was collected and washed with $\mathrm{H}_{2} \mathrm{O}(3 \times 50 \mathrm{~mL})$, sat. aq. $\mathrm{NaHCO}_{3}(4 \times 50 \mathrm{~mL})$ and brine $(60 \mathrm{~mL})$ before it was 
dried over anhydrous $\mathrm{MgSO}_{4}$. Filtration and concentration in vacuo yielded the crude material as a white powder. Recrystallisation from hexanes : $\mathrm{Et}_{2} \mathrm{O}$ yielded tri-Oacetyl-D-glucal 37 as a white solid (14.9 g, 65\%). The spectral data matched those previously reported. ${ }^{36,79}$

$\mathrm{R}_{f}=0.26$ (3:1 hexanes : EtOAc, v:v); M.p. 48.5-50.5 ${ }^{\circ} \mathrm{C}$ (lit. 50.0-52.0 $\left.{ }^{\circ} \mathrm{C}\right){ }^{114}$; $[\alpha]_{\mathrm{D}}{ }^{26.6}=-2.0\left(\mathrm{c}=1.0, \mathrm{CH}_{2} \mathrm{Cl}_{2}\right) ;{ }^{1} \mathrm{H} \mathrm{NMR}\left(500 \mathrm{MHz}, \mathrm{CDCl}_{3}\right): \delta 6.47(\mathrm{~d}, J=6.4 \mathrm{~Hz}, 1 \mathrm{H}$, H-1), 5.34 (m, 1H, H-3), 5.22 (dd, $J=7.6,5.9 \mathrm{~Hz}, 1 \mathrm{H}, \mathrm{H}-4), 4.84$ (dd, $J=6.3,3.4 \mathrm{~Hz}$, $1 \mathrm{H}, \mathrm{H}-2), 4.4$ (dd, $J=12.2,5.8 \mathrm{~Hz}, 1 \mathrm{H}, \mathrm{H}-6 \mathrm{a}), 4.26$ (m, 1H, H-5), 4.20 (dd, $J=12.2$, $3.2 \mathrm{~Hz}, 1 \mathrm{H}, \mathrm{H}-6 \mathrm{~b}), 2.09$ (s, 3H, $\mathrm{CH}_{3} \mathrm{CO}$ ), 2.08 (s, 3H, $\left.\mathrm{CH}_{3} \mathrm{CO}\right), 2.04$ (s, 3H, $\left.\mathrm{CH}_{3} \mathrm{CO}\right) ;{ }^{13} \mathrm{C}$ NMR (125 MHz, $\left.\mathrm{CDCl}_{3}\right): \delta 170.7\left(\mathrm{C}, \mathrm{CH}_{3} \mathrm{CO}\right), 170.5\left(\mathrm{C}, \mathrm{CH}_{3} \mathrm{CO}\right)$, $169.6\left(\mathrm{C}, \mathrm{CH}_{3} \mathrm{CO}\right), 145.6$ (CH, C-1), 99.0 (CH, C-2), 74.0 (CH, C-5), 67.5 (CH, C-3), 67.2 (CH, C-4), $61.4(\mathrm{CH}, \mathrm{C}-6), 21.0\left(\mathrm{CH}_{3}, \mathrm{CH}_{3} \mathrm{CO}\right), 20.83\left(\mathrm{CH}_{3}, \mathrm{CH}_{3} \mathrm{CO}\right), 20.77$ $\left(\mathrm{CH}_{3}, \mathrm{CH}_{3} \mathrm{CO}\right.$ ); IR (film from $\left.\mathrm{CH}_{2} \mathrm{Cl}_{2}\right): v_{\max }=2982,1742,1650,1433,1370,1221$, $1141,1030,601 \mathrm{~cm}^{-1}$.

\section{D-Glucal (38)}

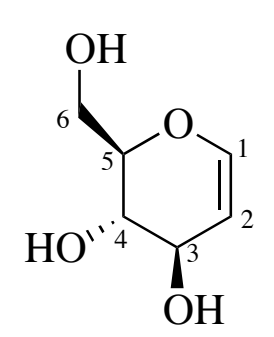

38

To a solution of sodium $(0.23 \mathrm{~g}, 9.84 \mathrm{mmol})$ in $\mathrm{MeOH}(300 \mathrm{~mL})$, a solution of 37 (8.87 g, $32.8 \mathrm{mmol})$ in $\mathrm{MeOH}(113 \mathrm{~mL})$ was added. The reaction was then left to stir at r.t. for $15 \mathrm{~min}$, after which TLCanalysis deemed the reaction complete. The solution was then concentrated in vacuo to provide the crude product. Purification was done through the successive additions of $\mathrm{MeOH}(7 \mathrm{~mL})$, acetone $(50 \mathrm{~mL})$ and $\mathrm{Et}_{2} \mathrm{O}(100 \mathrm{~mL})$. The solution was then filtered and concentrated in vacuo to afford the pure glucal 38 as viscous yellow oil (4.77 g, 99.4\%). Spectral data matched those previously reported. ${ }^{36}$

$\mathrm{R}_{f}=0.30\left(\right.$ EtOAc); $[\alpha]_{\mathrm{D}}{ }^{26.7}=+8.0\left(\mathrm{c}=1.0, \mathrm{H}_{2} \mathrm{O}\right) ;{ }^{1} \mathrm{H}$ NMR: $\left(500 \mathrm{MHz}, \mathrm{D}_{2} \mathrm{O}\right) \delta 6.29$ (dd, $J=5.8,1.3 \mathrm{~Hz}, 1 \mathrm{H}, \mathrm{H}-1), 4.68-4.65$ (m, 3H, 3 x OH), 4.80 (dd, $J=6.1,2.4 \mathrm{~Hz}$, 1H, H-2), 4.23 (ddd, $J=7.0,2.3,1.7$ Hz, 1H, H-3), 3.92- 3.85 (m, 3H, H-5, H-6a, H6b), $3.67(\mathrm{dd}, J=9.0,7.1 \mathrm{~Hz}, 1 \mathrm{H}, \mathrm{H}-4) ;{ }^{13} \mathrm{C} \mathrm{NMR}\left(125 \mathrm{MHz}, \mathrm{D}_{2} \mathrm{O}\right) \delta 143.6(\mathrm{CH}, \mathrm{C}-$ 
1), 102.7 (CH, C-2), 78.0 (CH, C-5), 68.7 (CH,C-4), 68.2 (CH, C-3), 60.0 (CH, C-6);

I IR (neat, $\mathrm{cm}^{-1}$ ) $v_{\max }=3293,28812,1648,1410,1228,1070,1011$,

\section{1,5-anhydro-2-deoxy-6-O-trityl-D-arabino-hex-1-enitol (39)}<smiles>O[C@H]1C=CO[C@H](COC(c2ccccc2)(c2ccccc2)c2ccccc2)[C@@H]1O</smiles>

39

In a modification of the Esswein procedure, ${ }^{84} \mathbf{3 8}(4.44 \mathrm{~g}, 32.64$ mmol) was dissolved in a solution of $\mathrm{CH}_{2} \mathrm{Cl}_{2}$ and pyridine (69 mL, 1:1, v:v) before trityl chloride (14.6 g, $52.22 \mathrm{mmol})$ was added over a period of 3 minutes at r.t. The solution was stirred for 19 hours at r.t. after which, TLC analysis showed completion of the reaction. The reaction was then concentrated in vacuo and extracted with $\mathrm{CHCl}_{3}(3 \times 60 \mathrm{~mL})$. The organic layers were then collected and washed with sat. aq. $\mathrm{NaHCO}_{3}(3 \times 60 \mathrm{~mL})$, dried over anhydrous $\mathrm{MgSO}_{4}$, filtered and concentrated in vacuo to provide a yellow oil. The crude yellow oil was then purified via silica gel column chromatography $(1: 1$ hexanes : EtOAc, v:v) to afford 39 as a white solid $(9.87 \mathrm{~g}, 87 \%)$.

$\mathrm{R}_{f}=0.48\left(2: 1\right.$ hexanes : EtOAc, v:v); M.p. 59.0-61.8 ${ }^{\circ} \mathrm{C}\left(\right.$ lit. $\left.62-64{ }^{\circ} \mathrm{C}\right) ;[\alpha]_{\mathrm{D}}^{25.4}=$ $+40.0\left(\mathrm{c}=1.0, \mathrm{CH}_{2} \mathrm{Cl}_{2}\right) ;{ }^{1} \mathrm{H}$ NMR $\left(500 \mathrm{MHz}, \mathrm{CDCl}_{3}\right): \delta 7.48-7.25(\mathrm{~m}, 15 \mathrm{H}, \mathrm{Ph}), 6.39$ $(\mathrm{dd}, J=6.1,1.7 \mathrm{~Hz}, 1 \mathrm{H}, \mathrm{H}-1), 4.76(\mathrm{dd}, J=6.1,2.2 \mathrm{~Hz}, 1 \mathrm{H}, \mathrm{H}-2), 4.24$ (d, $J=6.6 \mathrm{~Hz}$ 1H, H-3), 3.9 (dd, $J=9.5,7.1 \mathrm{~Hz}, 1 \mathrm{H}, \mathrm{H}-4), 3.84$ (dt, $J=13.2,3.6 \mathrm{~Hz}, 1 \mathrm{H}, \mathrm{H}-5), 3.57$ (dd, $J=10.5,3.6 \mathrm{~Hz}, 1 \mathrm{H}, \mathrm{H}-6 \mathrm{a}), 3.36$ (dd, $J=10.5,3.9 \mathrm{~Hz}, 1 \mathrm{H}, \mathrm{H}-6 \mathrm{~b}), 2.33$ (m, 1H, $\mathrm{OH}-4) ;{ }^{13} \mathrm{C}$ NMR (125 MHz, $\left.\mathrm{CDCl}_{3}\right): \delta 144.6(\mathrm{CH}, \mathrm{C}-1), 143.4(\mathrm{C}, \mathrm{Ph}), 128.5(\mathrm{CH}$, $\mathrm{Ph}), 128.0$ (CH, Ph), 127.3 (CH, Ph), 102.5 (CH, C-2), 87.0 (C, C-7), 76.5 (CH, C-5), $71.6(\mathrm{CH}, \mathrm{C}-4), 69.4$ (CH, C-3), 62.8 (CH, C-6); IR: $v_{\max }=3342,3058,2880,1644$, 1489, 1447, 1226, 1000, 745, 697. 


\section{1,5-Anhydro-3,4-di- $O$-benzyl-2-deoxy-6-O-trityl-D-arabino-hex-1-enitol (40)}

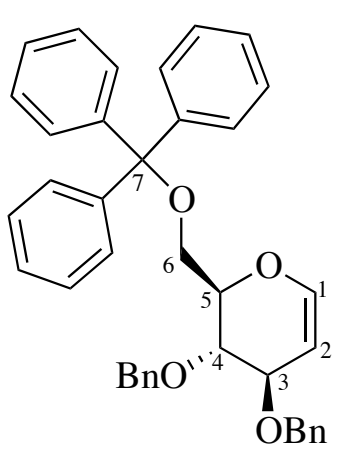

40

In a slight modification of Schmidt's procedure, ${ }^{84} 39$ (1.05 g, $2.71 \mathrm{mmol})$ was co-evaporated in vacuo with DMF $(18 \mathrm{~mL})$ two times, with an additional evaporation whereupon the volume of DMF $(30 \mathrm{~mL})$ was reduced to half to ensure dryness. The solution was then cooled to $-5{ }^{\circ} \mathrm{C}$ before $\mathrm{NaH}$ $(0.3 \mathrm{~g}, 7.3 \mathrm{mmol})$ was added portion-wise over a period of 3 minutes followed by the addition of TBAI $(0.1 \mathrm{~g}, 0.27 \mathrm{mmol})$.

The solution was left to stir for $15 \mathrm{~min}$ before the dropwise addition of $\mathrm{BnBr}(0.9 \mathrm{~mL}, 7.3 \mathrm{mmol})$, after which it was allowed to warm to room temperature and left to stir overnight. After TLC analysis showed the disappearance of starting materials, the reaction was then quenched with $\mathrm{H}_{2} \mathrm{O}(8 \mathrm{~mL})$ and extracted with $\mathrm{CHCl}_{3}(3 \times 10 \mathrm{~mL})$. The organic fractions were combined, dried over anhydrous $\mathrm{MgSO}_{4}$, and concentrated under reduced pressure to give the crude product. The crude material was then purified via silica gel column chromatography $(14: 1 \rightarrow 1: 1$ hexanes : EtOAc, v:v) to produce $\mathbf{4 0}$ as a white solid (1.32 g, 86\%).

$\mathrm{R}_{f}=0.40$ (9:1 hexanes : EtOAc); M.p. $114.0-116.0{ }^{\circ} \mathrm{C}\left(\right.$ lit. $\left.116{ }^{\circ} \mathrm{C}^{84}\right) ;[\alpha]_{\mathrm{D}}{ }^{24.2}=+0.6$ $\left(\mathrm{c}=1.0, \mathrm{CH}_{2} \mathrm{Cl}_{2}\right) ;{ }^{1} \mathrm{H}$ NMR $\left(500 \mathrm{MHz}, \mathrm{CDCl}_{3}\right): \delta 7.48-7.01(\mathrm{~m}, 25 \mathrm{H}, \mathrm{Ph}), 6.49(\mathrm{~d}, J=$ $6 \mathrm{~Hz}, 1 \mathrm{H}, \mathrm{H}-1), 4.88$ (dd, $J=6.0,4.0 \mathrm{~Hz}, 1 \mathrm{H}, \mathrm{H}-2), 4.73$ (d, $J=11 \mathrm{~Hz} 1 \mathrm{H}, \mathrm{PhCH}_{2}$ ), $4.62\left(\mathrm{~d}, J=11.5 \mathrm{~Hz}, 1 \mathrm{H}, \mathrm{PhCH}_{2}\right), 4.55$ (d, $\left.J=11.5 \mathrm{~Hz}, 1 \mathrm{H}, \mathrm{PhCH}_{2}\right), 4.5$ (d, $J=11$ $\left.\mathrm{Hz}, 1 \mathrm{H}, \mathrm{PhCH}_{2}\right), 4.17$ (m, 1H, H-3), 4.0 (m, 2H, H-4, H-5), 3.54 (d, J=10 Hz, 1H, H6a), 3.39 (dd, $J=10,4 \mathrm{~Hz}, 1 \mathrm{H}, \mathrm{H}-6 \mathrm{~b}) ;{ }^{13} \mathrm{C} \mathrm{NMR}\left(125 \mathrm{MHz}, \mathrm{CDCl}_{3}\right): \delta 144.9(\mathrm{CH}, \mathrm{C}-$ 1), 143.9 (C, Ph), 138.3 (C, Ph), 138.1 (C, Ph), 128.8 (CH, Ph), 128.4 (CH, Ph), 128.2 (CH, Ph), 127.9 (CH, Ph), $127.8(\mathrm{CH}, \mathrm{Ph}), 127.64(\mathrm{CH}, \mathrm{Ph}), 127.6(\mathrm{CH}, \mathrm{Ph}), 126.9$ $(\mathrm{CH}, \mathrm{Ph}), 99.8$ (CH, C-2), 86.5 (C, C-7), $77.2(\mathrm{CH}, \mathrm{C}-5), 76.1(\mathrm{CH}, \mathrm{C}-3), 74.6(\mathrm{CH}$, C-4), $73.8\left(\mathrm{CH}_{2}, \mathrm{PhCH}_{2}\right), 70.8\left(\mathrm{CH}_{2}, \mathrm{PhCH}_{2}\right), 62.1\left(\mathrm{CH}_{2}, \mathrm{C}-6\right)$; IR (film from $\mathrm{CH}_{2} \mathrm{Cl}_{2}$ ): $v_{\max } 3060,3030,2923,2874,1744,1647,1492,1449,1238,1099,1068$, $1028,900,745,698 \mathrm{~cm}^{-1}$. 


\section{1,5-anhydro-3,4-di- $O$-benzyl-6- $O$-(triphenylcarbinyl)-2-deoxy-1,2- $C$ -}

(dichloromethylene)-D-glycero-D-gulo-hexitol (41) and 1,5-anhydro-3,4-di- $O$ benzyl-6- $O$-(triphenylcarbinyl)-2-deoxy-1,2- $C$ - (dichloromethylene)-D-glycero-Dtalo-hexitol (42)

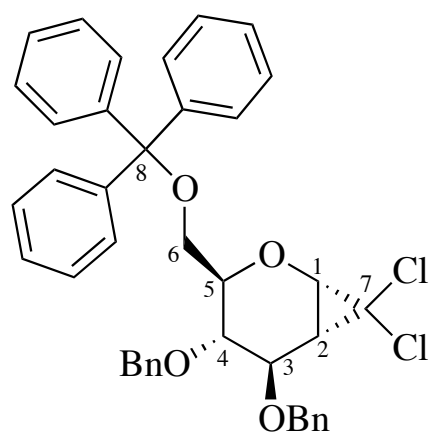

41

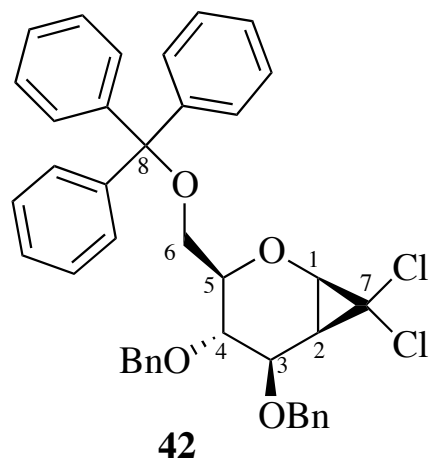

In a modification of the procedure conducted by Gross and colleagues, ${ }^{86}$ a solution of the protected glucal $\mathbf{4 0}$ (1.29 g, $2.27 \mathrm{mmol})$ in $\mathrm{CHCl}_{3}(8.2 \mathrm{~mL})$ was treated with TEBAC (16 mg, $0.078 \mathrm{mmol})$, followed by the dropwise addition of $33 \% \mathrm{NaOH}$ in $\mathrm{H}_{2} \mathrm{O}(12 \mathrm{~mL})$. The biphasic solution was stirred rapidly for 48 hours at r.t., after which TLC analysis showed completion of the reaction. The reaction mixture was then quenched with $\mathrm{H}_{2} \mathrm{O}$ $(60 \mathrm{~mL})$ and extracted with $\mathrm{CH}_{2} \mathrm{Cl}_{2}(3 \times 60 \mathrm{~mL})$. The organic layer was collected, dried over anhydrous $\mathrm{MgSO}_{4}$ and concentrated in vacuo to afford a crude mixture of both stereoisomers $\mathbf{4 1}$ and $\mathbf{4 2}$. The crude products were purified using column chromatography (14:1 hexanes : EtOAc, v:v) to afford the major isomer $41(1.23 \mathrm{~g}, 83 \%)$ as a white solid and the minor product $42(0.26 \mathrm{~g}, 13 \%)$ as a yellow oil.

Data for 41: $\mathrm{R}_{f}=0.52\left(9: 1\right.$ hexanes : EtOAc); M.p. $51.5-53.5{ }^{\circ} \mathrm{C} ;[\alpha]_{\mathrm{D}}{ }^{25.7}=+8.0$ (c=1.0, $\left.\mathrm{CH}_{2} \mathrm{Cl}_{2}\right) ;{ }^{1} \mathrm{H}$ NMR $\left(500 \mathrm{MHz}, \mathrm{CDCl}_{3}\right): \delta 7.47-7.22(\mathrm{~m}, 25 \mathrm{H}, \mathrm{Ph}), 4.81(\mathrm{~d}, J=$ $\left.3.9 \mathrm{~Hz}, 1 \mathrm{H}, \mathrm{PhCH}_{2}\right), 4.79\left(\mathrm{~d}, J=3.2 \mathrm{~Hz}, 1 \mathrm{H}, \mathrm{PhCH}_{2}\right), 4.70(\mathrm{~d}, J=11.5 \mathrm{~Hz}, 1 \mathrm{H}$, $\mathrm{PhCH}_{2}$ ), 4.26 (d, $\left.J=10.8 \mathrm{~Hz}, 1 \mathrm{H}, \mathrm{PhCH}_{2}\right), 4.05$ (d, $\left.J=8 \mathrm{~Hz}, 1 \mathrm{H}, \mathrm{H}-1\right), 3.88-3.84$ (m, 2H, H-4, H-5), 3.78 (dd, $J=9.5,4.9 \mathrm{~Hz}, 1 \mathrm{H}, \mathrm{H}-3), 3.48$ (dd, $J=10.5,2.4 \mathrm{~Hz}, 1 \mathrm{H}, \mathrm{H}-$ 6a), 3.17 (dd, $J=10.3,3.0 \mathrm{~Hz}, 1 \mathrm{H}, \mathrm{H}-6 \mathrm{~b}), 1.89$ (dd, $J=8.1,4.9 \mathrm{~Hz}, 1 \mathrm{H}, \mathrm{H}-2) ;{ }^{13} \mathrm{C}$ NMR (125 MHz, $\left.\mathrm{CDCl}_{3}\right): \delta 147.7$ (C, Ph), 138.0 (C, Ph), 137.6 (C, Ph), 128.9 (C, $\mathrm{Ph}), 128.8$ (C, Ph), 128.4 (C, Ph),128.1 (C, Ph), 128.0 (C, Ph), 127.9 (C, Ph), 127.8 (C, Ph), 127.1 (C, Ph), 86.7 (C, C-8), 80.3 (C, C-5), 77.4 (CH, C-4), 75.7 (CH, C-4), $74.8\left(\mathrm{CH}_{2}, \mathrm{PhCH}_{2}\right), 72.0\left(\mathrm{CH}_{2}, \mathrm{PhCH}_{2}\right), 63.6\left(\mathrm{CH}_{2}, \mathrm{C}-6\right), 61.6(\mathrm{C}, \mathrm{C}-7), 59.2(\mathrm{CH}, \mathrm{C}-$ 
1), $34.6(\mathrm{CH}, \mathrm{C}-2)$ ) IR (film from $\mathrm{CH}_{2} \mathrm{Cl}_{2}$ ): $v_{\max } 3086,3060,3030,2924,2868,1491$, $1449,1130,1093,1014,744,697,632 \mathrm{~cm}^{-1}$.

Data for 42: $\mathrm{R}_{f}=0.29$ (9:1 hexanes: EtOAc, v:v); $[\alpha]_{\mathrm{D}}{ }^{25.9}=-6.0\left(\mathrm{c}=1.0, \mathrm{CH}_{2} \mathrm{Cl}_{2}\right)$; M.p. 49-51 ${ }^{\circ} \mathrm{C} ;{ }^{1} \mathrm{H}$ NMR $\left(500 \mathrm{MHz}, \mathrm{CDCl}_{3}\right.$ ): $\delta 7.50-7.17$ (m, 23H, Ph), 6.90 (dd, J=7.3, $1.4 \mathrm{~Hz}, 2 \mathrm{H}, \mathrm{Ph}), 4.87$ (d, J=11.7 Hz, 1H, $\mathrm{PhCH}_{2}$ ), 4.74 (d, J=12.0 Hz, 1H, $\mathrm{PhCH}_{2}$ ), 4.69 (d, $\left.J=10.5 \mathrm{~Hz}, 1 \mathrm{H}, \mathrm{PhCH}_{2}\right), 4.34$ (d, $\left.J=10.7 \mathrm{~Hz}, 1 \mathrm{H}, \mathrm{PhCH}_{2}\right), 4.14-4.09$ (m, 2H, H-3, H- 4), 4.05 (d, $J=8.1 \mathrm{~Hz}, 1 \mathrm{H}, \mathrm{H}-1$ ), 3.56 (dd, $J=10.3,2.0 \mathrm{~Hz}, 1 \mathrm{H}, \mathrm{H}-6 \mathrm{a})$, 3.41 (m, 1H, H-5), 3.19 (dd, $J=9.3,2.9 \mathrm{~Hz}, 1 \mathrm{H}, \mathrm{H}-6 \mathrm{~b}), 2.12$ (t, $J=7.8 \mathrm{~Hz}, 1 \mathrm{H}, \mathrm{H}-2$ );

${ }^{13} \mathrm{C}$ NMR (125 MHz, $\left.\mathrm{CDCl}_{3}\right): \delta 143.9(\mathrm{C}, \mathrm{Ph}), 138.1(\mathrm{C}, \mathrm{Ph}), 137.9(\mathrm{C}, \mathrm{Ph}), 128.8$ (CH, Ph), 128.6 (CH, Ph), 128.1 (CH, Ph), 128.06 (CH, Ph), 127.93 (CH, Ph), 127.91 (CH, Ph), $127.84(\mathrm{CH}, \mathrm{Ph}), 127.79(\mathrm{CH}, \mathrm{Ph}), 127.5(\mathrm{CH}, \mathrm{Ph}), 86.4(\mathrm{C}, \mathrm{C}-8), 78.3$ (CH, C-5), 78.1 (CH, C-4), $76.4(\mathrm{CH}, \mathrm{C}-3), 74.8\left(\mathrm{CH}_{2}, \mathrm{PhCH}_{2}\right), 71.5\left(\mathrm{CH}_{2}, \mathrm{PhCH}_{2}\right)$, $62.2\left(\mathrm{CH}_{2}, \mathrm{C}-6\right), 62.12(\mathrm{CH}, \mathrm{C}-1), 61.9(\mathrm{CH}, \mathrm{C}-7), 33.0(\mathrm{CH}, \mathrm{C}-2)$; IR (film from $\mathrm{CH}_{2} \mathrm{Cl}_{2}$ ): $v_{\max } 3380,3061,3030,2932,2875,1647,1491,1449,1275,1091,1022$, $747,699 \mathrm{~cm}^{-1}$.

\section{1,5-anhydro-3,4-di-O-benzyl-2-deoxy-1,2-C-(dichloromethylene)-D-glycero-D- gulo-hexitol (23) and 1,5-anhydro-3,4-di-O-benzyl-6-O-(formyl)-2-deoxy-1,2- $C$ - (dichloromethylene)-D-glycero-D-gulo-hexitol (42)}

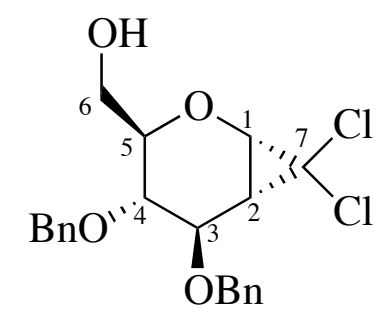

23

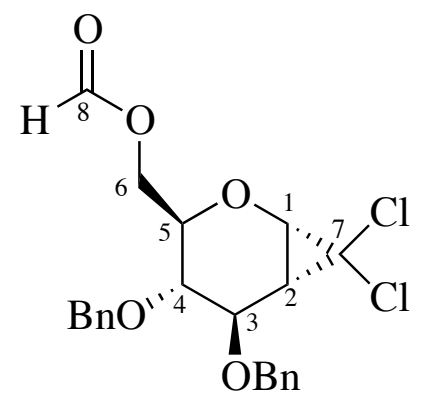

43
To a solution of 41 (1.23 g, $1.9 \mathrm{mmol})$ in $\mathrm{Et}_{2} \mathrm{O}(11 \mathrm{~mL})$, formic acid $(9.05 \mathrm{~mL})$ was added dropwise. The solution was left to stir at r.t. for a period of $50 \mathrm{~min}$ before it was diluted with $\mathrm{Et}_{2} \mathrm{O}(90 \mathrm{~mL})$. The organic layer was collected, washed with sat. aq. $\mathrm{NaHCO}_{3}(4 \times 100 \mathrm{~mL})$, dried over anhydrous $\mathrm{MgSO}_{4}$, and concentrated in vacuo to afford the crude products 23 and 43 . The crude products were purified via column chromatography $(14: 1 \rightarrow 5: 1$ hexanes : EtOAc, v:v) to give $23(0.64 \mathrm{~g}, 81 \%)$ as a white solid and $43(0.067 \mathrm{~g}$, $8 \%)$ as clear oil. 
Data for 23: $\mathrm{R}_{f}=0.53$ (3:1 hexanes : ethyl acetate, v:v); M.p. 84.5-86.0 ${ }^{\circ} \mathrm{C}$; $[\alpha]_{\mathrm{D}}{ }^{25.5}=+29.0\left(\mathrm{c}=1.0, \mathrm{CH}_{2} \mathrm{Cl}_{2}\right) ;{ }^{1} \mathrm{H} \mathrm{NMR}\left(500 \mathrm{MHz}, \mathrm{CDCl}_{3}\right): \delta 7.42-7.26(\mathrm{~m}, 10 \mathrm{H}$, $\mathrm{Ph}), 4.95\left(\mathrm{~d}, J=11.2 \mathrm{~Hz}, 1 \mathrm{H}, \mathrm{PhCH}_{2}\right), 4.81\left(\mathrm{~d}, J=12.0 \mathrm{~Hz}, 1 \mathrm{H}, \mathrm{PhCH}_{2}\right), 4.71(\mathrm{~d}, J=$ $\left.11.8 \mathrm{~Hz}, 1 \mathrm{H}, \mathrm{PhCH}_{2}\right), 4.67$ (d, $\left.J=11.2 \mathrm{~Hz}, 1 \mathrm{H}, \mathrm{PhCH}_{2}\right), 3.87$ (d, J=8.5 Hz, 1H, H1), $3.81(\mathrm{dd}, J=9.2,3.9 \mathrm{~Hz}, 1 \mathrm{H}, \mathrm{H}-3), 3.73$ (dt, $J=8.3,3.7 \mathrm{~Hz}, 1 \mathrm{H}, \mathrm{H}-5), 3.68$ (s, 2H, H-6a,b), 3.59 (t, $J=8.7 \mathrm{~Hz}, 1 \mathrm{H}, \mathrm{H}-4), 1.83$ (dd, $J=8.3,3.9 \mathrm{~Hz}, 1 \mathrm{H}, \mathrm{H}-2$ ), 1.75 (s, $1 \mathrm{H}, \mathrm{OH}) ;{ }^{13} \mathrm{C}$ NMR $\left(125 \mathrm{MHz}, \mathrm{CDCl}_{3}\right) \delta 137.9(\mathrm{C}, \mathrm{Ph}), 137.4(\mathrm{C}, \mathrm{Ph}), 128.6(\mathrm{CH}, \mathrm{Ph}$ ), $128.5(\mathrm{CH}, \mathrm{Ph}), 128.2(\mathrm{CH}, \mathrm{Ph}), 128.0(\mathrm{CH}, \mathrm{Ph}), 127.98(\mathrm{CH}, \mathrm{Ph}), 79.4(\mathrm{CH}, \mathrm{C}-$ 5), 77.3 (CH, C-3), $74.8\left(\mathrm{CH}_{2}, \mathrm{PhCH}_{2}\right), 74.7(\mathrm{CH}, \mathrm{C}-4), 72.0\left(\mathrm{CH}_{2}, \mathrm{PhCH}_{2}\right), 62.7$ $\left(\mathrm{CH}_{2}, \mathrm{C}-6\right), 60.9(\mathrm{C}, \mathrm{C}-7), 58.8(\mathrm{CH}, \mathrm{C}-1), 33.7(\mathrm{CH}, \mathrm{C}-2)$. IR (neat, $\left.\mathrm{cm}^{-1}\right) v_{\max }=$ 3362, 3935, 2954, 2912, 2863, 1496, 1453, 1327, 1108, 989, 885, 820, 731, 694.

Data for 43: $\mathrm{R}_{f}=0.30\left(9: 1\right.$ hexanes : EtOAc, v:v); $[\alpha]_{\mathrm{D}}{ }^{26.6}=+18.0\left(\mathrm{c}=1.0, \mathrm{CH}_{2} \mathrm{Cl}_{2}\right) ;{ }^{1} \mathrm{H}$ NMR (500MHz, $\left.\mathrm{CDCl}_{3}\right): \delta 8.03(\mathrm{~m}, 1 \mathrm{H}, \mathrm{CHO}), 7.47-7.26(\mathrm{~m}, 10 \mathrm{H}, \mathrm{Ph}), 4.95(\mathrm{~d}, J=$ $\left.11.5 \mathrm{~Hz}, 1 \mathrm{H}, \mathrm{PhCH}_{2}\right), 4.81\left(\mathrm{~d}, J=11.8 \mathrm{~Hz}, 1 \mathrm{H}, \mathrm{PhCH}_{2}\right), 4.70(\mathrm{~d}, J=12 \mathrm{~Hz}, 1 \mathrm{H}$, $\left.\mathrm{PhCH}_{2}\right), 4.63$ (d, $\left.J=11.2 \mathrm{~Hz}, 1 \mathrm{H}, \mathrm{PhCH}_{2}\right), 4.30$ (dd, $\left.J=11.7,4.8,1 \mathrm{H}, \mathrm{H}-6 \mathrm{a}\right), 4.15$ (dd, $J=12.2,2.7,1 \mathrm{H}, \mathrm{H}-6 \mathrm{~b}), 3.87$ (dddd, $J=8.3,5.1,2.7,0.7 \mathrm{~Hz}, 1 \mathrm{H}, \mathrm{H}-5$ ), 3.86 (d, $J=7.8 \mathrm{~Hz}, 1 \mathrm{H}, \mathrm{H}-1), 3.80$ (dd, $J=9.3,4.1 \mathrm{~Hz}, 1 \mathrm{H}, \mathrm{H}-3), 3.57$ (t, $J=8.6 \mathrm{~Hz}, 1 \mathrm{H}, \mathrm{H}-$ 4), $1.82(\mathrm{dd}, J=8.0,4.6 \mathrm{~Hz}, 1 \mathrm{H}, \mathrm{H}-2) ;{ }^{13} \mathrm{C} \mathrm{NMR}\left(125 \mathrm{MHz}, \mathrm{CDCl}_{3}\right) \delta 160.5(\mathrm{C}, \mathrm{C}-8)$, 137.6 (C, Ph), 137.3 (C, Ph), 128.6 (CH, Ph ), 128.5 (CH, Ph ), $128.3(\mathrm{CH}, \mathrm{Ph})$, $128.1(\mathrm{CH}, \mathrm{Ph}), 128.0(\mathrm{CH}, \mathrm{Ph}), 127.99$ (CH, Ph ), 77.7 (CH, C-5), 77.3 (CH, C-3), $74.7\left(\mathrm{CH}_{2}, \mathrm{PhCH}_{2}\right), 74.4(\mathrm{CH}, \mathrm{C}-4), 71.9\left(\mathrm{CH}_{2}, \mathrm{PhCH}_{2}\right), 63.2\left(\mathrm{CH}_{2}, \mathrm{C}-6\right), 60.9(\mathrm{C}, \mathrm{C}-$ 7), $58.4(\mathrm{CH}, \mathrm{C}-1), 34.0(\mathrm{CH}, \mathrm{C}-2)$; IR (neat, $\left.\mathrm{cm}^{-1}\right) v_{\max }=3031,2869,1724,1497$, 1454, 1151, 1087, 733, 696. 
<smiles>CC(C)(C)[Si](OC[C@H]1OC=C[C@@H](O)[C@@H]1O)(c1ccccc1)c1ccccc1</smiles>

44

Using a modification of Lellouche and co-workers' procedure,$^{92}$ imidazole $(0.45 \mathrm{~g}, 6.6 \mathrm{mmol})$ was added to a solution of D-glucal 38 (0.46 g, $3.2 \mathrm{mmol})$ in DMF $(7.5 \mathrm{~mL})$ and then cooled to $-18^{\circ} \mathrm{C}$ using dry ice in a 9:1 ethylene glycol : ethanol (v:v) slurry. TBDPSCl $(0.83 \mathrm{~mL}, 3.2 \mathrm{mmol})$ was then added dropwise and the reaction was left overnight at $-18{ }^{\circ} \mathrm{C}$. After TLC analysis showed the disappearance of starting materials, the solution was quenched by the addition of $\mathrm{H}_{2} \mathrm{O}(20 \mathrm{~mL})$ and extracted with $\mathrm{Et}_{2} \mathrm{O}(3 \times 8 \mathrm{~mL})$. The organic fractions were combined and washed with $\mathrm{H}_{2} \mathrm{O}$ $(5 \mathrm{~mL})$, dried over anhydrous $\mathrm{MgSO}_{4}$, and concentrated in vacuo to give the crude product as a viscous yellow oil. Purification by silica gel column chromatography (1:1 hexanes: ethyl acetate, v:v) yielded 44 as a colourless viscous oil (226 mg, 19\%). Spectral data matched those previously reported. ${ }^{92}$

$\mathrm{R}_{f}=0.38\left(1: 1\right.$ hexanes : EtOAc, v:v); $[\alpha]_{\mathrm{D}}{ }^{27.7}=+38.0\left(\mathrm{c}=1.0, \mathrm{CH}_{2} \mathrm{Cl}_{2}\right) ;{ }^{1} \mathrm{H}$ NMR: $(500$ $\left.\mathrm{MHz}, \mathrm{CDCl}_{3}\right) \delta$ 7.69-7.67 (m, 4H,), 7.47-7.39 (m, 6H), 6.32 (dd, $J=6.5,2 \mathrm{~Hz}, 1 \mathrm{H}, \mathrm{H}-$ 1), 4.73 (dd, $J=6.0,2.0 \mathrm{~Hz}, 1 \mathrm{H}, \mathrm{H}-2), 4.27$ (d, $J=7.1,1 \mathrm{H}, \mathrm{H}-3), 3.99-3.97$ (m, 2H, H-6a, H-6b), 3.95-3.79 (m, 2H, H-4, H-5), 2.78 (s, 2.18, 1H, OH), 2.15 (s, 1H, OH), 1.07 (s, 9H); ${ }^{13} \mathrm{C}$ NMR (125 MHz, $\left.\mathrm{CDCl}_{3}\right) \delta 144.3$ (C, C-1), 135.7 (C, Ph), 135.5 (CH, Ph), 132.8 (CH, Ph), 130.0 (CH, Ph), 127.9 (CH, Ph), 102.3 (CH, C-2), 76.7 (CH, C-5), 71.9 (CH, C-4), $69.6(\mathrm{CH}, \mathrm{C}-3), 63.8$ (CH, C-6), $26.8\left(\mathrm{CH}_{3}, \mathrm{SiCH}_{3}\right), 19.25$ $\left(\mathrm{CH}_{3}, \mathrm{SiCH}_{3}\right)$; IR (neat, $\left.\mathrm{cm}^{-1}\right) \quad v_{\max }=3367,3071,3013,2930,2857,1646,1472$, 1428, 1233, 1107, 1051, 753, 701. 
<smiles>CC(C)(C)O[C@H]1C=CO[C@@H](CO[Si](c2ccccc2)(c2ccccc2)C(C)(C)C)[C@@H]1OCc1ccccc1</smiles>

45

In a slight modification of Schmidt's procedure, ${ }^{84}$ the protected diol $44(0.217 \mathrm{~g}, 0.6 \mathrm{mmol})$ was dissolved in DMF $(7 \mathrm{~mL})$ and cooled to $-5^{\circ} \mathrm{C}$. $\mathrm{BnBr}(0.17 \mathrm{~mL}, 1.4 \mathrm{mmol})$ was then added dropwise, followed by the portionwise addition of $\mathrm{NaH}(0.034$ $\mathrm{g}, 1.4 \mathrm{mmol}$ ) over a period of 1 minute. The reaction was then left to warm to r.t. and react overnight. TLC analysis showed that the reaction was not complete therefore addition of catalytic amounts of TBAI $(0.02 \mathrm{~g}, 0.06 \mathrm{mmol})$ was added to aid in the completion of the reaction. Following completion of the reaction, deemed by TLC analysis, it was quenched by the addition of $\mathrm{H}_{2} \mathrm{O}(20 \mathrm{~mL})$ and extracted with $\mathrm{CHCl}_{3}(3 \times 20 \mathrm{~mL})$. The organic fractions were combined, dried over anhydrous $\mathrm{MgSO}_{4}$, and concentrated in vacuo to give the crude product. The crude material was then purified via silica gel column chromatography $(9: 1 \rightarrow 1: 1$ hexanes : EtOAc, v:v) to give $45(80 \mathrm{mg}, 25 \%)$,

$\mathrm{R}_{f}=0.40\left(12: 1\right.$ hexanes : EtOAc, v:v); $[\alpha]_{\mathrm{D}}{ }^{27.7}=+24.0\left(\mathrm{c}=1.0, \mathrm{CH}_{2} \mathrm{Cl}_{2}\right) ;{ }^{1} \mathrm{H}$ NMR $(500$ $\left.\mathrm{MHz}, \mathrm{CDCl}_{3}\right): \delta$ 7.7-7.66 (m, 5H, Ph), 7.38-7.28 (m, 15H, Ph), 6.40 (dd, $J=6,1 \mathrm{~Hz}$, 1H, H-1), 4.91 (d, $J=11 \mathrm{~Hz}, 1 \mathrm{H}, \mathrm{PhCH}_{2}$ ), 4.85 (dd, $\left.J=6,2.5 \mathrm{~Hz}, 1 \mathrm{H} . \mathrm{H}-2\right), 4.75$ (d, $\left.J=11.5 \mathrm{~Hz}, 1 \mathrm{H}, \mathrm{PhCH}_{2}\right), 4.65\left(\mathrm{~d}, J=11.5 \mathrm{~Hz}, 1 \mathrm{H}, \mathrm{PhCH}_{2}\right), 4.59$ (d, $J=11.5 \mathrm{~Hz}$, 1H, $\mathrm{PhCH}_{2}$ ), 4.23 (m, 1H, H-3), 4.05-4.01 (m, 2H, H-4, H-5), 3.97-3.93 (m, 2H, H6a, H6b), 1.05 (s, 9H); ${ }^{13} \mathrm{C}$ NMR (125 MHz, $\left.\mathrm{CDCl}_{3}\right) \delta 154.0(\mathrm{C}, \mathrm{C}-1), 135.1(\mathrm{C}, \mathrm{Ph})$, 135.0 (CH, Ph), 130.2 (CH, Ph), 127.9 (CH, Ph), 127.7 (CH, Ph), 99.9 (CH, C-2), 76.7 (CH, C-5), 75.7 (CH, C-3), 74.4 (CH, C-4), $73.5\left(\mathrm{CH}_{2}, \mathrm{PhCH}_{2}\right), 70.5\left(\mathrm{CH}_{2}\right.$, $\left.\mathrm{PhCH}_{2}\right), 68.5(\mathrm{CH}, \mathrm{C}-6), 26.5\left(\mathrm{CH}_{3}, \mathrm{SiCH}_{3}\right), 19.0\left(\mathrm{CH}_{3}, \mathrm{SiCH}_{3}\right)$; IR (neat, $\left.\mathrm{cm}^{-1}\right)$ $v_{\max }=3399$, 3070, 2930, 2858, 1496, 1427, 1361, 1107, 820, 739, 696, 607, 502. 
<smiles></smiles>

In a modification of Patnaik and colleagues' procedure, ${ }^{93}$ acetyl chloride $(2.5 \mathrm{~mL}, 34.6 \mathrm{mmol})$ was added dropwise to $\mathrm{MeOH}(16 \mathrm{~mL})$ at $0{ }^{\circ} \mathrm{C}$ and stirred for a period of 40 minutes before the portion-wise addition of glycine $(1.0 \mathrm{~g}, 13.3 \mathrm{mmol})$. The solution was then heated to reflux and left to stir for a period of 3 hours. Completion of the reaction was indicated by TLC-analysis, after which the solution was concentrated under reduced pressure to produce $\mathbf{4 6}$ as an off-white solid (1.68 g, quant.).

$\mathrm{R}_{f}=0.68$ (2:10 Methanol : EtOAc, v:v); M.p. 174.0-175.0 ${ }^{\circ} \mathrm{C} ;{ }^{1} \mathrm{H}$ NMR (500MHz, $\mathrm{D}_{2} \mathrm{O}$ ): $\delta 3.92$ (s, 2H, H-1a, H-1b), 3.84 (s, 3H, H-3); ${ }^{13} \mathrm{C}$ NMR (125 MHz, $\mathrm{D}_{2} \mathrm{O}$ ): $\delta$ $168.60(\mathrm{C}, \mathrm{C}-2), 53.23(\mathrm{C}, \mathrm{C}-1), 39.92\left(\mathrm{CH}_{3}, \mathrm{C}-3\right)$; IR (neat, $\left.\mathrm{cm}^{-1}\right) v_{\max }=3011$, 2881, 2686, 2632, 1743, 1583, 1495, 1437, 1400, 1256, 1139, 1057, 955, 900, 879.

\section{Ethyl glycinate hydrochloride (47)}<smiles>CCOC(=O)C([Al])[Al]</smiles>

addition of glycine $(1.0 \mathrm{~g}, 13.3 \mathrm{mmol})$. The reaction was then heated to reflux and left to stir for a period of 3 hours. After TLC-analysis deemed the reaction complete, the solution was concentrated under reduced pressure to afford 47 as an off white solid (1.82 g, quant.).

$\mathrm{R}_{f}=0.60$ (2:10 Methanol : EtOAc, v:v); M.p. 142.6-143.0 ${ }^{\circ} \mathrm{C} ;{ }^{1} \mathrm{H}$ NMR (500MHz, $\mathrm{D}_{2} \mathrm{O}$ ): $\delta 4.29$ (dd, $\left.J=14.5,7.5 \mathrm{~Hz}, 2 \mathrm{H}, \mathrm{H}-1 \mathrm{a}, \mathrm{H}-1 \mathrm{~b}\right), 3.9$ (s, 2H, H-3a, H-3b), 1.28 (t, $\left.J=7.5 \mathrm{~Hz}, 3 \mathrm{H}, \mathrm{CH}_{3}\right) ;{ }^{13} \mathrm{C}$ NMR $\left(125 \mathrm{MHz}, \mathrm{D}_{2} \mathrm{O}\right): \delta 168.09$ (C, C-2), 63.21 (C, C-1), 40.07 (C, C-3), $13.07\left(\mathrm{CH}_{3}, \mathrm{C}-4\right)$; IR (neat, $\left.\mathrm{cm}^{-1}\right) \quad v_{\max }=2975,2909,2635,1742$, $1503,1411,1244,1135,1051,904,854$. 
<smiles>CCCCOC(=O)CN</smiles>

48

In a modification of Patnaik, S., and colleagues procedure ${ }^{93} n$-butanol $(16 \mathrm{~mL})$ was cooled to $0{ }^{\circ} \mathrm{C}$ followed by the dropwise addition of acetyl chloride $(2.5 \mathrm{~mL}$, $34.6 \mathrm{mmol})$. The solution was stirred at $0{ }^{\circ} \mathrm{C}$ for $40 \mathrm{~min}$. Glycine $(1 \mathrm{~g}, 13.3 \mathrm{mmol})$ was then added portionwise over $1 \mathrm{~min}$. The reaction was then heated to reflux and left to stir for 3 hours. TLC (2:10 Methanol : EtOAc, v:v) analysis showed completion of the reaction. The solution was then concentrated under reduced pressure to afford 48 (2.18 g, Quan. yield) as an off white solid.

$\mathrm{R}_{f}=0.48$ (2:10 Methanol : EtOAc, v:v); M.p. 71.0-71.5 ${ }^{\circ} \mathrm{C} ;{ }^{1} \mathrm{H}$ NMR (500MHz, $\mathrm{D}_{2} \mathrm{O}$ ): $\delta 4.25$ (t, J=7.2 Hz, 2H, H-1a, H-1b), 3.9 (s, 2H, H-3a, H-3b), 1.65 (t, J= 7.5 Hz, 2H, H-4a, H-4b), 1.36 (dd, $J=15,7.5$ Hz, 2H, H-5a, H-5b), 0.89 (t, $J=7.5 \mathrm{~Hz}$, $3 \mathrm{H}, \mathrm{H}-6 \mathrm{a}, \mathrm{H}-6 \mathrm{~b}, \mathrm{H}-6 \mathrm{c}) ;{ }^{13} \mathrm{C}$ NMR (125 MHz, $\left.\mathrm{D}_{2} \mathrm{O}\right): \delta 168.20$ (C, C-2), 66.88 (C, C1), 40.03 (C, C-3), 29.61 (C, C-4), 18.28 (C, C-5), $12.77\left(\mathrm{CH}_{3}, \mathrm{C}-6\right)$; IR (neat, $\mathrm{cm}^{-1}$ ) $v_{\max }=2955,2873,2697,2603,1740,1477,1379,1238,1220,1133,1062,917$.

\section{Ethyl diazoacetate (49)}<smiles></smiles>

In a slight variation for the well-established method by Searle, ${ }^{100}$ a solution of ethyl glycinate $47(0.523 \mathrm{~g}$, $3.7 \mathrm{mmol})$ in $\mathrm{H}_{2} \mathrm{O}(1 \mathrm{~mL})$ and $\mathrm{CH}_{2} \mathrm{Cl}_{2}(2.2 \mathrm{~mL})$ was cooled to $-5{ }^{\circ} \mathrm{C}$. An ice cold solution of sodium nitrite ( $0.38 \mathrm{~g}, 4.4 \mathrm{mmol})$ and $\mathrm{H}_{2} \mathrm{O}(1 \mathrm{~mL})$ was then added and the reaction was further cooled to $-9{ }^{\circ} \mathrm{C}$. Paying careful attention to retaining the cold temperature, $5 \% \mathrm{H}_{2} \mathrm{SO}_{4}$ $(0.01 \mathrm{~mL}, 0.18 \mathrm{mmol}, \mathrm{w} / \mathrm{w})$ in $\mathrm{H}_{2} \mathrm{O}(0.34 \mathrm{~mL})$ was then added dropwise over a period of 10 minutes. The solution was left to stir for a period of 15 minutes at $-9{ }^{\circ} \mathrm{C}$ before TLC analysis showed the completion of reaction. The solution was then transferred to an ice-cold separating funnel containing a solution of cold $5 \% \mathrm{NaHCO}_{3}$ in $\mathrm{H}_{2} \mathrm{O}$ $(1 \mathrm{~mL}, \mathrm{w} / \mathrm{w})$, followed by extraction with $\mathrm{CH}_{2} \mathrm{Cl}_{2}(3 \times 10 \mathrm{~mL})$. The organic layers were then collected, combined, and transferred back into an ice-cold separating 68 
funnel, followed by repetitive washings with $\mathrm{NaHCO}_{3}$ until the solution is basic as according to indicator paper. The organic layer was again collected, dried over anhydrous $\mathrm{NaSO}_{4}$, and filtered. The final product was not concentrated due to its explosive nature and a $70 \%$ yield of $\mathbf{4 9}$ was assumed as stated in the literature. ${ }^{100}$

$\mathrm{R}_{f}=0.50$ (3:1 Hexanes : EtOAc, v:v); M.p. 124.8-126.0 ${ }^{\circ} \mathrm{C} ;{ }^{1} \mathrm{H}$ NMR (500MHz, $\mathrm{D}_{2} \mathrm{O}$ ): $\delta 4.19$ (dd, $J=14.0,7.0$ Hz, 2H, H-1a, H-1b), 3.89 (s, 2H, H-3a, H-3b), 1.27 (t, $\left.J=7.0 \mathrm{~Hz}, 3 \mathrm{H}, \mathrm{CH}_{3}\right) ;{ }^{13} \mathrm{C} \mathrm{NMR}\left(125 \mathrm{MHz}, \mathrm{D}_{2} \mathrm{O}\right): \delta 168.1$ (C, C-2), $63.20(\mathrm{C}, \mathrm{C}-1)$, 40.06 (C, C-3), $13.57\left(\mathrm{CH}_{3}, \mathrm{C}-4\right)$; IR (film from $\left.\mathrm{CH}_{2} \mathrm{Cl}_{2}\right): v_{\max } 2987,2113,1745$, $1625,1244,1196,1066,1025,767 \mathrm{~cm}^{-1}$.

\section{Rhodium (II) acetate dimer (50).}

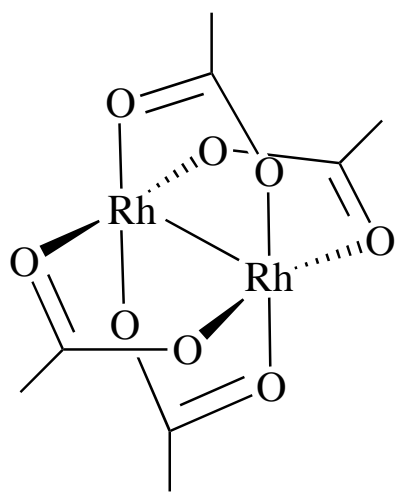

50

Following methodology of Legzdins and colleagues, ${ }^{115}$ rhodium chloride trihydrate $(100 \mathrm{mg}, 0.38 \mathrm{mmol})$ and sodium acetate trihydrate $(200 \mathrm{mg}, 1.48 \mathrm{mmol})$ were dissolved in absolute EtOH $(2 \mathrm{~mL})$ and acetic acid $(2 \mathrm{~mL})$ and heated to reflux for a period of 1 hour. Upon reflux, the solution rapidly turned green and a green precipitate was deposited. Once the solution had cooled to r.t., the solution was filtered and the solid collected and recrystallised from boiling $\mathrm{MeOH}$. The crystals were dried at $45{ }^{\circ} \mathrm{C}$ in vacuo for a period of 40 hours to yield the dimer $\mathbf{5 0}$ as emerald green crystals $(0.048 \mathrm{~g}$, $28.2 \%)$.

M.p. $202{ }^{\circ} \mathrm{C} ;{ }^{1} \mathrm{H}$ NMR (500MHz, $\left.\mathrm{D}_{2} \mathrm{O}\right): \delta 1.90$ (s, 12H, $\left.\mathrm{CH}_{3}\right) ;{ }^{13} \mathrm{C}$ NMR (125 MHz, $\left.\mathrm{D}_{2} \mathrm{O}\right): \delta 169.12\left(\mathrm{C}, \mathrm{CO}_{2}\right), 20.91\left(\mathrm{C}, \mathrm{CH}_{3}\right)$; IR (film from $\mathrm{CH}_{2} \mathrm{Cl}_{2}$ ): v $v_{\max } 2970,2929$, $2857,1738,1682,1584,1415,1365,1217,695 \mathrm{~cm}^{-1}$. 


\section{1,5-Anhydro-2-deoxy-1,2-C-(exo-carbmethoxymethylene)-3,4,6-O-acetyl- $\alpha$-D- arabino-hexitol (51)}<smiles>CCOC(=O)[C@@H]1O[C@H](COC(C)=O)[C@@H]2[C@H](OC(C)=O)[C@H](OC(C)=O)[C@H]12</smiles>

51

In a modification of the procedure proposed by Hoberg and colleagues, ${ }^{33}$ the dimer 50 (0.01 g, $0.02 \mathrm{mmol}$ ) was added to a solution of glucal 37 (0.09 g, $0.34 \mathrm{mmol})$ in dry $\mathrm{CH}_{2} \mathrm{Cl}_{2}(1.5 \mathrm{~mL})$ and stirred vigorously under argon atmosphere. A solution of ethyl diazoacetate (49) $(0.165 \mathrm{~g}, 1.36$ mmol) in dry $\mathrm{CH}_{2} \mathrm{Cl}_{2}(4.4 \mathrm{~mL})$ was then added dropwise over a period of 14 hours via a syringe pump. After addition of the ethyl diazoacetate solution TLC analysis showed the presence of both starting material and product. The reaction solution was then concentrated in vacuo and purified via silica gel column chromatography $(5: 1 \rightarrow 1: 1$ hexanes : EtOAc, v:v) to yield $\mathbf{5 1}$ as a pale yellow viscous oil $(0.032 \mathrm{~g}, 27 \%)$.

$\mathrm{R}_{f}=0.40\left(2: 1\right.$ hexanes : EtOAc, v:v); $[\alpha]_{\mathrm{D}}{ }^{26.9=}+31.0^{\circ}\left(\mathrm{c}=1.0, \mathrm{CH}_{2} \mathrm{Cl}_{2}\right) ;{ }^{1} \mathrm{H}$ NMR $\left(500 \mathrm{MHz}, \mathrm{CDCl}_{3}\right): \delta 5.1$ (d, $\left.J=4.5 \mathrm{~Hz}, 1 \mathrm{H}, \mathrm{H}-4\right), 4.86$ (t, $\left.J=4.5 \mathrm{~Hz}, 1 \mathrm{H}, \mathrm{H}-3\right), 4.48$ (dd, $J=12,7$ Hz, 1H, H-6a), 4.15-4.11 (m, 3H, H-6b, H-9a, H-9b), 3.95 (dd, $J=7.5$, $2.0 \mathrm{~Hz}, 1 \mathrm{H}, \mathrm{H}-1), 3.85$ (m, 1H, H-5), 2.1-2.07 (m, 9H, $\mathrm{CH}_{3} \mathrm{CO}$ ), 2.04 (t, $J=9.5 \mathrm{~Hz}$, $1 \mathrm{H}, \mathrm{H}-7), 1.77$ (t, $J=? ? \mathrm{~Hz}, 1 \mathrm{H}, \mathrm{H}-2), 1.3-1.25$ (m, 3H, $\left.\mathrm{CH}_{3}-\mathrm{Et}\right) ;{ }^{13} \mathrm{C}$ NMR (125 $\left.\mathrm{MHz}, \mathrm{CDCl}_{3}\right): \delta 170.7(\mathrm{C}, \mathrm{C}-8), 169.5\left(\mathrm{C}, \mathrm{CH}_{3} \mathrm{CO}\right), 168.5\left(\mathrm{C}, \mathrm{CH}_{3} \mathrm{CO}\right), 168.1(\mathrm{C}$, $\left.\mathrm{CH}_{3} \mathrm{CO}\right), 71.9(\mathrm{CH}, \mathrm{C}-5), 68.4(\mathrm{CH}, \mathrm{C}-4), 66.9$ (CH, C-3), 61.8 (CH, C-6), $61.1\left(\mathrm{CH}_{2}\right.$, C-9), 55.9 (CH, C-1), 24.6 (CH, C-2), 23.1 (CH, C-7), $20.92\left(\mathrm{CH}_{3}, \mathrm{CH}_{3} \mathrm{CO}\right), 20.86$ $\left(\mathrm{CH}_{3}, \mathrm{CH}_{3} \mathrm{CO}\right), 20.79\left(\mathrm{CH}_{3}, \mathrm{CH}_{3} \mathrm{CO}\right), 14.2(\mathrm{C}, \mathrm{C}-10)$; IR (neat, $\left.\mathrm{cm}^{-1}\right) v_{\max }=2983$, 1739, 1368, 1214, 1182, 1130, 1030, 914. 


\section{1,5-Anhydro-3,4-di- $O$-benzyl-2-deoxy-1,2- $C$-(exo-carbmethoxymethylene)-D-}

glycero-D-gulo-hexitol (54), 1,5-Anhydro-3,4-di- $O$-benzyl-2-deoxy-1,2- $C$-(exocarbmethoxymethylene)-D-glycero-D-talo-hexitol (55) and 1,5-Anhydro-3,4-di- $O$ benzyl-6- $O$-(formyl)-2-deoxy-1,2- $C$-(exo-carbmethoxymethylene)-D-glycero-Dgulo-hexitol (56)

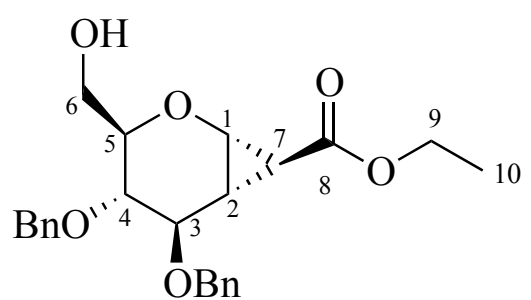

54<smiles>CCOC(=O)[C@H]1[C@H]2O[C@H](CO)[C@@H](OCc3ccccc3)[C@@H](O)[C@@H]21</smiles>

55

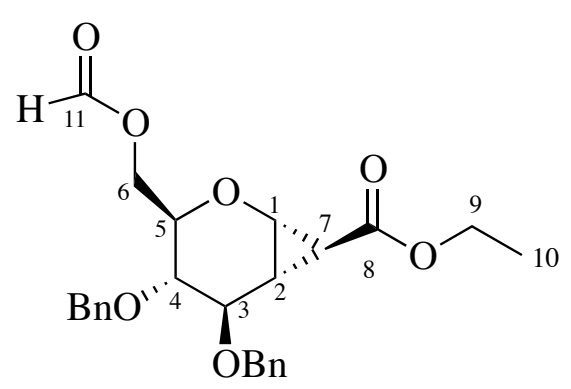

56

In a modification of the procedure reported by Hoberg and Claffey, ${ }^{76}$ the dimer 50 (0.042 g, 0.095 mmol) was added to a solution of the protected glucal 40 (1.09 g, $1.9 \mathrm{mmol})$ in dry $\mathrm{CH}_{2} \mathrm{Cl}_{2}(8 \mathrm{~mL})$ and the resulting mixture stirred vigorously. A solution of ethyl diazoacetate $49(4.2 \mathrm{~mL}$, $5.7 \mathrm{mmol})$ in dry $\mathrm{CH}_{2} \mathrm{Cl}_{2}(27 \mathrm{~mL})$ was then added dropwise over a period of 14 hours $(2.3 \mathrm{~mL} / \mathrm{h})$ via a syringe pump. According to literature the reaction was quenched after 14 hours. The reaction mixture was then concentrated in vacuo and purified via silica gel column chromatography $(20: 1 \rightarrow 5: 1$ hexanes : EtOAc, v:v). However, consistant with the report of Risseeuw and colleagues, ${ }^{104}$ this led to an inseparable mixture of both stereoisomers $\mathbf{5 2}$ and $\mathbf{5 3}$ as a clear viscous oil $(0.723 \mathrm{~g}, 58 \%)$. The inseparable stereoisomers 52 and 53 (0.545 g, $0.84 \mathrm{mmol})$ were then dissolved in $\mathrm{Et}_{2} \mathrm{O}(4.5 \mathrm{~mL})$ and treated with the dropwise addition of formic acid $(3.9 \mathrm{~mL}, 104 \mathrm{mmol})$. The reaction was left to stir for 50 minutes, after which TLC analysis showed the presence of both starting material and product. It is important to note that the reaction should not be left for longer in order to avoid the formation of a C6-formyl by-product. The solution was diluted in $\mathrm{Et}_{2} \mathrm{O}(40 \mathrm{~mL})$, washed with sat. aq. $\mathrm{NaHCO}_{3}(4$ x $50 \mathrm{~mL})$, and dried over anhydrous $\mathrm{MgSO}_{4}$. The solution was filtered and concentrated in vacuo to produce the crude product as a viscous yellow oil. Purification via silica gel column chromatography $(14: 1 \rightarrow 1: 1$ hexanes : EtOAc) yielded 54 (208 mg, 61\%), 55 (68 mg, 20\%), and 56 (7.7 mg, 2\%) as pale yellow oils. 
Data for 54: $\mathrm{R}_{f}=0.40\left(2: 1\right.$ hexanes : EtOAc, v:v); $[\alpha]_{\mathrm{D}}{ }^{26.7}=+3.0\left(\mathrm{c}=1.0, \mathrm{CH}_{2} \mathrm{Cl}_{2}\right)$; ${ }^{1} \mathrm{H}$ NMR $\left(500 \mathrm{MHz}, \mathrm{CDCl}_{3}\right): \delta 7.35-7.28(\mathrm{~m}, 10 \mathrm{H}, \mathrm{Ph}), 4.76(\mathrm{~d}, J=11.5 \mathrm{~Hz}, 2 \mathrm{H}$, $\left.\mathrm{PhCH}_{2}\right), 4.62\left(\mathrm{~d}, J=11.5 \mathrm{~Hz}, 1 \mathrm{H}, \mathrm{PhCH}_{2}\right), 4.59$ (d, $\left.J=12 \mathrm{~Hz}, 1 \mathrm{H}, \mathrm{PhCH}_{2}\right), 4.16$ (m, 2H, $\mathrm{CH}_{2}$-Et), 3.95 (dd, $J=7.5,2.0 \mathrm{~Hz}, 1 \mathrm{H}, \mathrm{H}-1$ ), 3.85 (d, $J=5.0 \mathrm{~Hz}, 1 \mathrm{H}, \mathrm{H}-3$ ), 3.79 (m, 1H, H-6a), 3.70 (m, 1H, H-6b), 3.50 (m, 2H, H-4, H-5), 2.02 (dd, J = 5.5, 2.5 Hz, 1H, H-7), 1.82 (t, $J=7.0 \mathrm{~Hz}, 1 \mathrm{H}, \mathrm{H}-2), 1.27$ (t, $\left.J=7.0 \mathrm{~Hz}, 3 \mathrm{H}, \mathrm{CH}_{3}-\mathrm{Et}\right) ;{ }^{13} \mathrm{C} \mathrm{NMR}$ (125 MHz, $\left.\mathrm{CDCl}_{3}\right): \delta 171.7(\mathrm{C}, \mathrm{C}-8), 137.8(\mathrm{C}, \mathrm{Ph}), 137.5(\mathrm{C}, \mathrm{Ph}), 128.6(\mathrm{CH}, \mathrm{Ph})$, 128.5 (CH, Ph), 128.1 (CH, Ph), 128.0 (CH, Ph), 127.95 (CH, Ph), $127.93(\mathrm{CH}, \mathrm{Ph})$, $127.8(\mathrm{CH}, \mathrm{Ph}), 76.4(\mathrm{CH}, \mathrm{C}-3), 75.2(\mathrm{CH}, \mathrm{C}-5), 73.9(\mathrm{CH}, \mathrm{C}-4), 73.6\left(\mathrm{CH}_{2}, \mathrm{PhCH}_{2}\right)$, $71.6\left(\mathrm{CH}_{2}, \mathrm{PhCH}_{2}\right), 62.1$ (CH, C-6), $60.8\left(\mathrm{CH}_{2}, \mathrm{C}-9\right), 58.1(\mathrm{CH}, \mathrm{C}-1), 23.9(\mathrm{CH}, \mathrm{C}-2)$, $23.3(\mathrm{CH}, \mathrm{C}-7), 14.2\left(\mathrm{CH}_{3}, \mathrm{C}-10\right)$; IR (neat, $\left.\mathrm{cm}^{-1}\right) v_{\max }=3483,3031,2980,2872$, $1715,1428,1298,1089,853,735,696$.

Data for 55: $\mathrm{R}_{f}=0.30\left(2: 1\right.$ hexanes : EtOAc, v:v); $[\alpha]_{\mathrm{D}}^{26.5}=-24.0\left(\mathrm{c}=1.0, \mathrm{CH}_{2} \mathrm{Cl}_{2}\right)$; ${ }^{1} \mathrm{H}$ NMR $\left(500 \mathrm{MHz}, \mathrm{CDCl}_{3}\right): \delta$ 7.38-7.28 (m, 10H, Ph), $4.98(\mathrm{~d}, J=11.5 \mathrm{~Hz}, 1 \mathrm{H}$, $\left.\mathrm{PhCH}_{2}\right), 4.77$ (d, $\left.J=11.5 \mathrm{~Hz}, 1 \mathrm{H}, \mathrm{PhCh}_{2}\right), 4.70$ (t, $\left.J=12.5 \mathrm{~Hz}, 2 \mathrm{H}, \mathrm{PhCH}_{2}\right), 4.49$ (dd, $J=9.5,4.5 \mathrm{~Hz}, 1 \mathrm{H}, \mathrm{H}-3$ ), 4.13 (q, $J=7.0 \mathrm{~Hz}, 2 \mathrm{H}, \mathrm{H}-9 \mathrm{a}, \mathrm{H} 9 \mathrm{~b}), 3.89$ (m, 2H, H-1, H-4), 3.66 (m, 2H, H-6a, H-6b), 3.60 (t, $J=9.0$ Hz, 1H, H-5), 1.75 (t, $J=6.0$ Hz, 1H, $\mathrm{OH}), 1.61$ (dd, $J=9.5,6.5 \mathrm{~Hz}, 1 \mathrm{H}, \mathrm{H}-7), 1.48(\mathrm{~m}, 1 \mathrm{H}, \mathrm{H}-2), 1.26(\mathrm{t}, J=7.5 \mathrm{~Hz}, 3 \mathrm{H}$, $\left.\mathrm{EtCH}_{3}\right) ;{ }^{13} \mathrm{C} \mathrm{NMR}\left(125 \mathrm{MHz}, \mathrm{CDCl}_{3}\right): \delta 168.8(\mathrm{C}, \mathrm{C}-8), 138.4(\mathrm{C}, \mathrm{Ph}), 138.3(\mathrm{C}, \mathrm{Ph})$, 128.4 (CH, Ph), 128.37 (CH, Ph), 128.0 (CH, Ph), 127.8 (CH, Ph), $127.7(\mathrm{CH}, \mathrm{Ph})$, 127.8 (CH, Ph), 79.8 (CH, C-3), 76.4 (CH, C-4), $74.4\left(\mathrm{CH}_{2}, \mathrm{PhCH}_{2}\right), 71.9\left(\mathrm{CH}_{2}\right.$, $\left.\mathrm{PhCH}_{2}\right), 63.0(\mathrm{CH}, \mathrm{C}-1), 60.5\left(\mathrm{CH}_{2}, \mathrm{C}-9\right), 53.6(\mathrm{CH}, \mathrm{C}-1), 24.2(\mathrm{CH}, \mathrm{C}-2), 22.0(\mathrm{CH}$, C-7), $14.3\left(\mathrm{CH}_{3}, \mathrm{C}-10\right)$; IR (neat, $\left.\mathrm{cm}^{-1}\right) v_{\max }=3054,1724,1422,1264,1072,896$, $732,704$.

Data for 56: $\mathrm{R}_{f}=0.50\left(3: 1\right.$ hexanes : EtOAc, v:v); $[\alpha]_{\mathrm{D}}{ }^{27.7}=+42.0\left(\mathrm{c}=1.0, \mathrm{CH}_{2} \mathrm{Cl}_{2}\right)$; ${ }^{1} \mathrm{H}$ NMR (500MHz, $\mathrm{CDCl}_{3}$ ): $\delta 8.05$ (s, 1H, H-11), 7.39-7.28 (m, 10H, Ph), 4.73 (d, $J$ $\left.=12 \mathrm{~Hz}, 1 \mathrm{H}, \mathrm{PhCH}_{2}\right), 4.72\left(\mathrm{~d}, J=11.5 \mathrm{~Hz}, 1 \mathrm{H}, \mathrm{PhCH}_{2}\right), 4.58(\mathrm{~d}, J=11.5 \mathrm{~Hz}, 1 \mathrm{H}$, $\left.\mathrm{PhCH}_{2}\right), 4.579$ (d, $\left.J=11.5 \mathrm{~Hz}, 1 \mathrm{H}, \mathrm{PhCH}_{2}\right), 4.46$ (dd, $\left.J=12.5,7.5 \mathrm{~Hz}, 1 \mathrm{H}, \mathrm{H}-6 \mathrm{a}\right)$, 4.20 (dd, $J=11.5,2.0 \mathrm{~Hz}, 1 \mathrm{H}, \mathrm{H}-6 \mathrm{~b}), 4.12$ (m, 2H, $\mathrm{CH}_{2}$-Et), 3.93 (dd, $J=7.0,2.0$ Hz, 1H, H-1), 3.82 (d, $J=6.0 \mathrm{~Hz}, 1 \mathrm{H}, \mathrm{H}-3), 3.75$ (m, 1H, H-5), 3.49 (t, $J=6.0 \mathrm{~Hz}$, 1H, H-4), 2.02 (dd, $J=5.5,2.0 \mathrm{~Hz}, 1 \mathrm{H}, \mathrm{H}-7), 1.83$ (t, $J=7.0 \mathrm{~Hz}, 1 \mathrm{H}, \mathrm{H}-2), 1.26$ (t, $J$ 72 
$\left.=7.0 \mathrm{~Hz}, 3 \mathrm{H}, \mathrm{CH}_{3}-\mathrm{Et}\right) ;{ }^{13} \mathrm{C} \mathrm{NMR}\left(125 \mathrm{MHz}, \mathrm{CDCl}_{3}\right): \delta 193.7(\mathrm{C}, \mathrm{C}-11), 171.4(\mathrm{C}, \mathrm{C}-$ 8), 137.6 (C, Ph), 137.5 (C, Ph), 128.54 (CH, Ph), 128.52 (CH, Ph), $128.0(\mathrm{CH}, \mathrm{Ph})$, 127.9 (CH, Ph), 127.8 (CH, Ph), $75.4(\mathrm{CH}, \mathrm{C}-3), 74.7\left(\mathrm{CH}_{2}, \mathrm{PhCH}_{2}\right), 72.6(\mathrm{CH}, \mathrm{C}-5)$, $71.5\left(\mathrm{CH}_{2}, \mathrm{PhCH}_{2}\right), 62.5(\mathrm{CH}, \mathrm{C}-6), 60.8\left(\mathrm{CH}_{2}, \mathrm{C}-9\right), 57.1(\mathrm{CH}, \mathrm{C}-1), 24.2(\mathrm{CH}, \mathrm{C}-2)$, $24.1(\mathrm{CH}, \mathrm{C}-7), 14.2\left(\mathrm{CH}_{2}, \mathrm{C}-10\right)$; IR (neat, $\left.\mathrm{cm}^{-1}\right) v_{\max }=3013,2872,1714,1454$, 1367, 1297, 1216, 1180, 1090, 748.

\section{$N, N$ '-Ditosylhydrazine (57)}

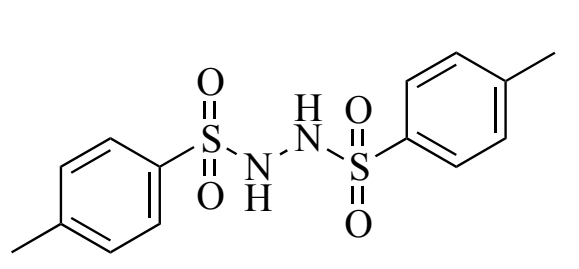

57

p-Toluenesulfonyl hydrazine $(5.5 \mathrm{~g}, 29.6 \mathrm{mmol})$ and $p$-toluenesulfonyl chloride $(8.5 \mathrm{~g}, 44.3 \mathrm{mmol})$ were dissolved in $\mathrm{CH}_{2} \mathrm{Cl}_{2}(50 \mathrm{~mL})$ and stirred vigorously at r.t., before it was treated to a dropwise addition of pyridine $(3.6 \mathrm{~mL})$. The addition of pyridine caused the solution to become homogenous and after 5 minutes a white precipitate was formed. The reaction mixture was left to stir at r.t. for 1.5 hours before it was cooled to $0{ }^{\circ} \mathrm{C}$, diluted with $\mathrm{Et}_{2} \mathrm{O}(120 \mathrm{~mL})$ and $\mathrm{H}_{2} \mathrm{O}(60 \mathrm{~mL})$, and left to stir for a further 15 minutes. The white precipitate was collected via Büchner filtration and washed with $\mathrm{Et}_{2} \mathrm{O}(100 \mathrm{~mL})$. Purification was achieved through recrystallisation from boiling $\mathrm{MeOH}(60 \mathrm{~mL})$. The recrystallised product was then collected and washed with cold $\mathrm{MeOH}(40 \mathrm{~mL})$ and $\mathrm{Et}_{2} \mathrm{O}(60 \mathrm{~mL})$ to give the final product 57 as white crystals $(8.13 \mathrm{~g}, 81 \%)$. Spectral data matches that of Toma and colleagues. ${ }^{109}$

$\mathrm{R}_{f}=0.50$ (3:1 hexanes : EtOAc, v:v); M.p. $209{ }^{\circ} \mathrm{C} ;{ }^{1} \mathrm{H}$ NMR $\left(500 \mathrm{MHz}, \mathrm{DMSO}-\mathrm{d}_{6}\right)$ : $\delta 8.73\left(\mathrm{~s}, 1 \mathrm{H}, \mathrm{SO}_{2} \mathrm{NH}\right), 6.79(\mathrm{~d}, J=8 \mathrm{~Hz}, 2 \mathrm{H}, \mathrm{Ph}), 6.54(\mathrm{~d}, J=8 \mathrm{~Hz}, 2 \mathrm{H}, \mathrm{Ph}), 1.54$ $\left(\mathrm{s}, 3 \mathrm{H}, \mathrm{CH}_{3}\right) ;{ }^{13} \mathrm{C}$ NMR $\left(125 \mathrm{MHz}, \mathrm{DMSO}_{6}\right) \delta 143.9(\mathrm{C}, \mathrm{Ph}), 135.9(\mathrm{C}, \mathrm{Ph}), 129.9$ $(\mathrm{CH}, \mathrm{Ph}), 128.2(\mathrm{CH}, \mathrm{Ph}), 21.5\left(\mathrm{C}, \mathrm{CH}_{3}\right)$; IR (neat, $\left.\mathrm{cm}^{-1}\right) v_{\max }=3232,3206,1598$, $1200,1189,1171,810$. 


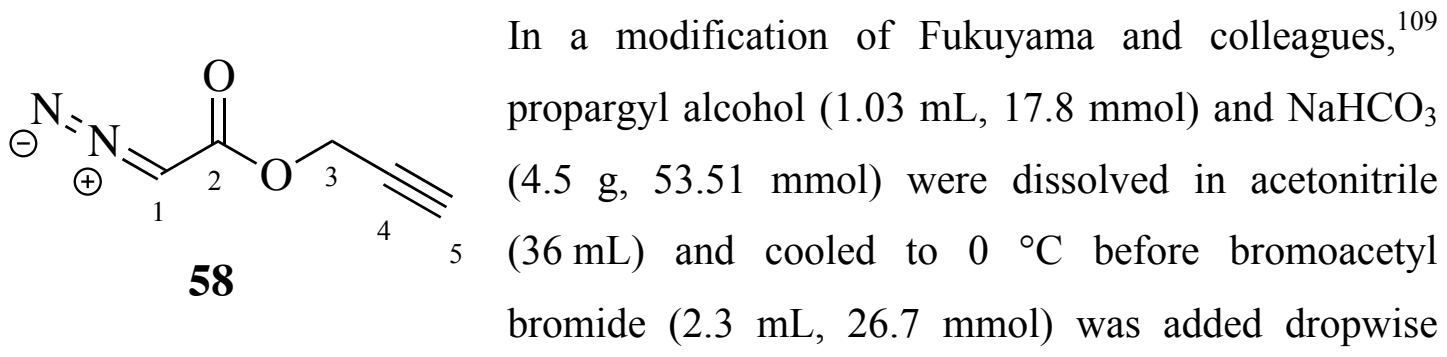
over a period of 3 minutes. Addition of bromoacetyl bromide caused the solution to become homogenous and the reaction was left to stir at $0{ }^{\circ} \mathrm{C}$ for 15 minutes before it was quenched with $\mathrm{H}_{2} \mathrm{O}(100 \mathrm{~mL})$. The solution was extracted with $\mathrm{CH}_{2} \mathrm{Cl}_{2}(3 \mathrm{x}$ $40 \mathrm{~mL}$ ) and the organic layers were collected and washed with brine $(3 \times 50 \mathrm{~mL})$ before being dried over anhydrous $\mathrm{MgSO}_{4}$, filtered, and concentrated in vacuo to leave a viscous orange oil. The formed bromoacetate product was used without further purification and along with $57(12 \mathrm{~g}, 35.6 \mathrm{mmol})$ was dissolved in THF before being cooled to $0{ }^{\circ} \mathrm{C}$. DBU $(13.3 \mathrm{~mL}, 13.3 \mathrm{mmol})$ was then added dropwise over a period of 5 minutes, causing the solution to turn into a homogenous mixture. The reaction was left to stir for 15 minutes at $0{ }^{\circ} \mathrm{C}$ before the reaction was quenched with sat. aq. $\mathrm{NaHCO}_{3}(60 \mathrm{~mL})$. The solution was extracted with $\mathrm{Et}_{2} \mathrm{O}(3 \times 40 \mathrm{~mL})$ and the organic layers were collected, washed with brine $(3 \mathrm{x} 40 \mathrm{~mL})$, dried over anhydrous $\mathrm{MgSO}_{4}$ and concentrated in vacuo to provide the crude product. Purification by neutralised silica gel column chromatography (3:1 hexanes : EtOAc, v:v) to give 58 as a viscous orange oil $(1.3 \mathrm{~g}, 57 \%)$. Spectral data matches that of Toma and colleagues. $^{109}$

$\mathrm{R}_{f}=0.50$ (3:1 hexanes : EtOAc, v:v); ${ }^{1} \mathrm{H}$ NMR $\left(500 \mathrm{MHz}, \mathrm{CDCl}_{3}\right): \delta 4.84-4.76(\mathrm{~m}$, $3 \mathrm{H}), 2.50-2.42(\mathrm{~m}, 1 \mathrm{H}) ;{ }^{13} \mathrm{C} \mathrm{NMR}\left(125 \mathrm{MHz}, \mathrm{CDCl}_{3}\right): \delta 165.8(\mathrm{C}, \mathrm{C}-2), 77.6(\mathrm{C}, \mathrm{C}-4)$, 75.0 (CH, C-5), 52.2 (C, C-1), 46.2 (C, C-3); IR (neat, $\mathrm{cm}^{-1}$ ) $v_{\max }=3286,3117,2951$, 2114, 1731, 1987, 1387, 1344, 1219, 1165, 1028, 993, 644. 
(1S,3R,4S,5R,6S)-prop-2-yn-1-yl-4,5-bis(benzyloxy)-3-(hydroxymethyl)-2oxabicyclo[4.1.0]heptane-7-carboxylate $(61)$ and $(1 R, 3 R, 4 S, 5 R, 6 R)$-prop-2-yn-1yl-4,5-bis(benzyloxy)-3-(hydroxymethyl)-2-oxabicyclo[4.1.0]heptane-7carboxylate (62)

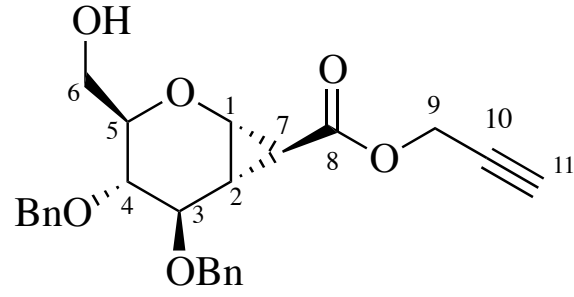

61<smiles>C#CCOC(=O)[C@H]1[C@H]2O[C@H](CO)[C@@H](OCc3ccccc3)[C@@H](O)[C@@H]21</smiles>

62

Using a modification of the method employed by Hoberg and colleagues, ${ }^{76}$ protected glucal 40 (1.0 g, $1.9 \mathrm{mmol}$ ) was dissolved in dry $\mathrm{CH}_{2} \mathrm{Cl}_{2}(8 \mathrm{~mL})$ and stirred under argon. Rhodium acetate $(0.047 \mathrm{~g}, 0.095 \mathrm{mmol})$ was then added to the reaction mixture, followed by vigorous stirring, before the dropwise addition of diazoacetate $58(0.7 \mathrm{~g}, 5.7 \mathrm{mmol})$ in $\mathrm{CH}_{2} \mathrm{Cl}_{2}$ $(27 \mathrm{~mL})$ via syringe pump over a period of 14 hours $(2.2 \mathrm{~mL} / \mathrm{h})$. The reaction was then left to stir for a further 3 hours before the solution was concentrated in vacuo to yield the crude product. The crude material was then purified via silica gel column chromatography $(20: 1 \rightarrow 1: 1$ hexanes $:$ EtOAc, v:v) to give an inseparable mixture of both stereoisomers 59 and $\mathbf{6 0}$ in a combined yield of $38 \%$ $(447 \mathrm{mg})$. The isomeric mixture was then dissolved in $\mathrm{Et}_{2} \mathrm{O}(4.1 \mathrm{~mL})$ and treated with a dropwise addition of formic acid $(3.2 \mathrm{~mL}, 84 \mathrm{mmol})$. The solution was allowed to stir for 50 minutes at r.t., after which TLC-analysis deemed the reaction complete. The reaction mixture was then diluted with $\mathrm{Et}_{2} \mathrm{O}(30 \mathrm{~mL})$ and washed with sat. aq. $\mathrm{NaHCO}_{3}(4 \times 30 \mathrm{~mL})$. The organic layer was collected, dried over anhydrous $\mathrm{MgSO}_{4}$, filtered and concentrated in vacuo to afford the crude material. Purification by silica gel column chromatography $\left(1: 100 \rightarrow 3: 10\right.$ EtOAc $: \mathrm{CH}_{2} \mathrm{Cl}_{2}$, v:v) to provide 61 (123 mg, 43\%) and $62(27 \mathrm{mg}, 10 \%)$ as clear viscous oils.

Data for 61: $\mathrm{R}_{f}=0.40\left(2: 1\right.$ hexanes : EtOAc, v:v); $[\alpha]_{\mathrm{D}}{ }^{27.7}=+38.0\left(\mathrm{c}=1.0, \mathrm{CH}_{2} \mathrm{Cl}_{2}\right)$; ${ }^{1} \mathrm{H}$ NMR $\left(500 \mathrm{MHz}, \mathrm{CDCl}_{3}\right): \delta 7.36-7.28(\mathrm{~m}, 10 \mathrm{H}, \mathrm{Ph}), 4.75(\mathrm{~d}, J=12.0 \mathrm{~Hz}, 2 \mathrm{H}$, $\mathrm{PhCH}_{2}$ ), 4.69 (dd, $\left.J=5.0,2.5 \mathrm{~Hz}, 2 \mathrm{H}, \mathrm{H}-9 \mathrm{a}, \mathrm{H}-9 \mathrm{~b}\right), 4.70$ (t, $J=12.0 \mathrm{~Hz}, 2 \mathrm{H}$, $\mathrm{PhCH}_{2}$ ), 4.00 (dd, $\left.J=7.5,2.5 \mathrm{~Hz}, 1 \mathrm{H}, \mathrm{H}-1\right), 3.85$ (d, $\left.J=4.5 \mathrm{~Hz}, 1 \mathrm{H}, \mathrm{H}-3\right), 3.79$ (m, 1H, H-6a), 3.70 (m, 1H, H-6b), 3.52 (m, 2H, H-4, H-5), 2.50 (t, $J=2.5$ Hz, 1H, H- 
11), $2.10(\mathrm{dd}, J=6.0,2.5 \mathrm{~Hz}, 1 \mathrm{H}, \mathrm{H}-7), 1.99$ (t, $J=6.0 \mathrm{~Hz}, 1 \mathrm{H}, \mathrm{OH}), 1.87$ (t, $J=7.0$ $\mathrm{Hz}, 1 \mathrm{H}, \mathrm{H}-2) ;{ }^{13} \mathrm{C} \mathrm{NMR}\left(\mathrm{CDCl}_{3}\right) \delta_{\mathrm{c}} 170.9(\mathrm{C}, \mathrm{C}-8), 137.8(\mathrm{C}, \mathrm{Ph}), 137.4(\mathrm{C}, \mathrm{Ph})$, $128.6(\mathrm{CH}, \mathrm{Ph}), 128.5(\mathrm{CH}, \mathrm{Ph}), 128.0(\mathrm{CH}, \mathrm{Ph}), 127.9(\mathrm{CH}, \mathrm{Ph}), 127.8(\mathrm{CH}, \mathrm{Ph})$, $76.0(\mathrm{CH}, \mathrm{C}-3), 75.1$ (CH, C-4), $75.0(\mathrm{CH}, \mathrm{C}-5), 73.9(\mathrm{CH}, \mathrm{C}-11), 73.6\left(\mathrm{CH}_{2}\right.$, $\left.\mathrm{PhCH}_{2}\right), 71.7\left(\mathrm{CH}_{2}, \mathrm{PhCH}_{2}\right), 62.0\left(\mathrm{CH}_{2}, \mathrm{C}-6\right), 58.4(\mathrm{CH}, \mathrm{C}-1), 52.3\left(\mathrm{CH}_{2}, \mathrm{C}-9\right), 24.5$ (CH, C-2), 23.0 (CH, C-7); IR (neat, $\mathrm{cm}^{-1}$ ) v $v_{\max }=3467,3286,3062,2871,1723$, 1427, 1292, 1209, 1117, 1088, 825, 736, 696.

Data for 62: $\mathrm{R}_{f}=0.40\left(2: 1\right.$ hexanes : EtOAc, v:v); $[\alpha]_{\mathrm{D}}{ }^{27.7}=+59.0\left(\mathrm{c}=1.0, \mathrm{CH}_{2} \mathrm{Cl}_{2}\right)$; ${ }^{1} \mathrm{H}$ NMR $\left(500 \mathrm{MHz}, \mathrm{CDCl}_{3}\right): \delta$ 7.38-7.29 (m, 10H, Ph), 4.99 (d, $J=11.5 \mathrm{~Hz}, 1 \mathrm{H}$, $\mathrm{PhCH}_{2}$ ), 4.75-4.61 (m, 5H, $\left.\mathrm{CH}_{2} \mathrm{Ph}, \mathrm{H}-9 \mathrm{a}, \mathrm{H}-9 \mathrm{~b}\right), 4.44$ (dd, $J=9.5,4.0 \mathrm{~Hz}, 1 \mathrm{H}, \mathrm{H}-3$ ), 3.92 (t, $J=6.5 \mathrm{~Hz}, 1 \mathrm{H}, \mathrm{H}-4), 3.90$ (dd, $J=9.0,4.0 \mathrm{~Hz}, 1 \mathrm{H}, \mathrm{H}-1), 3.66$ (m, 2H, H-6a, H-6b), 3.61 (t, $J=9.0 \mathrm{~Hz}, 1 \mathrm{H}, \mathrm{H}-5$ ), 2.49 (t, $J=2.0 \mathrm{~Hz}, 1 \mathrm{H}, \mathrm{H}-11$ ), 1.75 (bs, 1H, $\mathrm{OH}), 1.65$ (dd, $J=9.5,6.5 \mathrm{~Hz}, 1 \mathrm{H}, \mathrm{H}-7), 1.55$ (dd, $J=7.0,4.0 \mathrm{~Hz}, 1 \mathrm{H}, \mathrm{H}-2) ;{ }^{13} \mathrm{C}$ NMR $\left(\mathrm{CDCl}_{3}\right) \delta_{\mathrm{c}} 167.9(\mathrm{C}, \mathrm{C}-8), 138.4(\mathrm{C}, \mathrm{Ph}), 138.2(\mathrm{C}, \mathrm{Ph}), 128.44(\mathrm{CH}, \mathrm{Ph})$, $128.4(\mathrm{CH}, \mathrm{Ph}), 128.0(\mathrm{CH}, \mathrm{Ph}), 127.9(\mathrm{CH}, \mathrm{Ph}), 127.8$ (CH, Ph), 79.8 (CH, C-3), 79.2 (CH, C-4), 74.9 (CH, C-11), $74.5\left(\mathrm{CH}_{2}, \mathrm{PhCH}_{2}\right), 73.9(\mathrm{CH}, \mathrm{C}-5), 72.1\left(\mathrm{CH}_{2}\right.$, $\left.\mathrm{PhCH}_{2}\right), 63.0\left(\mathrm{CH}_{2}, \mathrm{C}-6\right), 54.1(\mathrm{CH}, \mathrm{C}-1), 51.9\left(\mathrm{CH}_{2}, \mathrm{C}-9\right), 24.9(\mathrm{CH}, \mathrm{C}-2), 21.7(\mathrm{CH}$, C-7); IR (neat, $\mathrm{cm}^{-1}$ ) $v_{\max }=3018,1733,1411,1215,1126,1099,747$. 


\section{Chapter 3}

\section{Biological analysis}

\subsection{Aims and objectives}

This aspect of the thesis focused on the elucidation of the mechanism of action of bioactive 1,2-cyclopropyl carbohydrates. Initial work was done testing the bioactivity of compounds $23,54,55,56,61$ and 62 through a liquid phase dose-response assays using $p d r 1 \Delta p d r 3 \Delta h i s 3 \Delta$ as a proxy wild-type yeast from the $p d r 1 \Delta p d r 3 \Delta x x x \Delta$ yeast genome deletion set. If the synthesised compounds show bioactivity, they will undergo a chemical genetic screen using the $p d r 1 \Delta p d r 3 \Delta x x x \Delta$ library, genetic interactions will be validated and subjected to a gene ontology search in order to identify chemical pathways involved in the mechanism of action of the drug. Finally, target isolation and identification will be attempted with either compound $\mathbf{6 1}$ or $\mathbf{6 2}$ through affinity purification by way of a copper-assisted azide-alkyne cycloaddition reaction with a modified agarose matrix.

\section{Introduction}

\subsection{Yeast as a model organism}

The budding yeast, Saccharomyces cerevisiae, has a long and well-documented history as the first eukaryotic organism to have undergone complete genomic sequencing, which was completed in $1996 .{ }^{116}$ In 1970, over 600 scientists from North America, Europe and Japan discussed the unique advantages $S$. cerevisiae offers as a model organism for eukaryotic cells as the natural progression from the extensive studies done on prokaryotic cells and phages. ${ }^{116}$ Accordingly, this led to the completion of the yeast $S$. cerevisiae genome project, which revealed the yeast's genome to be much more compact than initially expected. The genome sequence of 
12 million nucleotides encodes approximately 6000 protein-encoding genes, which is about $70 \%$ of the total genome. In contrast, the human genome contains approximately 2.85 billion nucleotides that only codes for 20,00-25,000 proteinencoding genes. ${ }^{117}$ Even compared to other yeast species the $S$. cerevisiaes genome is remarkably unique with a much higher ratio of protein-coding genes to genome nucleotides. ${ }^{118,116}$ Coinciding with the completion of the yeast genome project was the first complete proteome of a eukaryotic cell. This led to the classification of yeast proteins into their functions, allowing researchers to see an approximate percentage of proteins involved in each cellular process. For example, a total of $7 \%$ of the proteome is involved in the process of intracellular trafficking, whereas $11 \%$ of its proteome is responsible in metabolism. ${ }^{116}$

Since the yeast genome project started four decades ago, the biochemical, genetic and genomic tools available to study this organism have greatly helped in solving many biological problems and questions, more so than any other eukaryotic cells. Accordingly, this has made yeast the most commonly used organism for understanding both vital cellular processes and human diseases. ${ }^{119}$ A great example of this has been the work on understanding telomeres and telomerase. Work done by Lingner and colleagues ${ }^{120}$ identified two essential genes in S. cerevisiae involved in the process of telomere formation, Est2 (reverse transcriptase) and Est1 (accessory proteins). Involvement of the two genes was tested and proven through site-directed mutagenesis in three key conserved amino acids, which led to a complete prevention of telomerase activity. ${ }^{120}$ This allowed for extensive research to be done on the mechanism of telomerase activity in yeast, however, the mechanism of telomerase activity in other eukaryotes remained unknown until an iterative profile search found human homologs of both the Est1 and Est2 genes, with the region of highest homology being the TPR sequence within the Est (figure 3.0). ${ }^{121}$ This extensive crossspecies homology allowed for the conduction of structure-function analysis of the human homolog of both Est1 (hEST1A, hEST1B, hEST1C) and Est2 (hTERT). Findings in human cell lines confirmed the results seen in S. cerevisiae with the human hEST1 and hTERT genes forming both protein-protein interactions in the formation of the telomerase complex, comparable to the Est2 and Est 1 genes. ${ }^{122}$ 


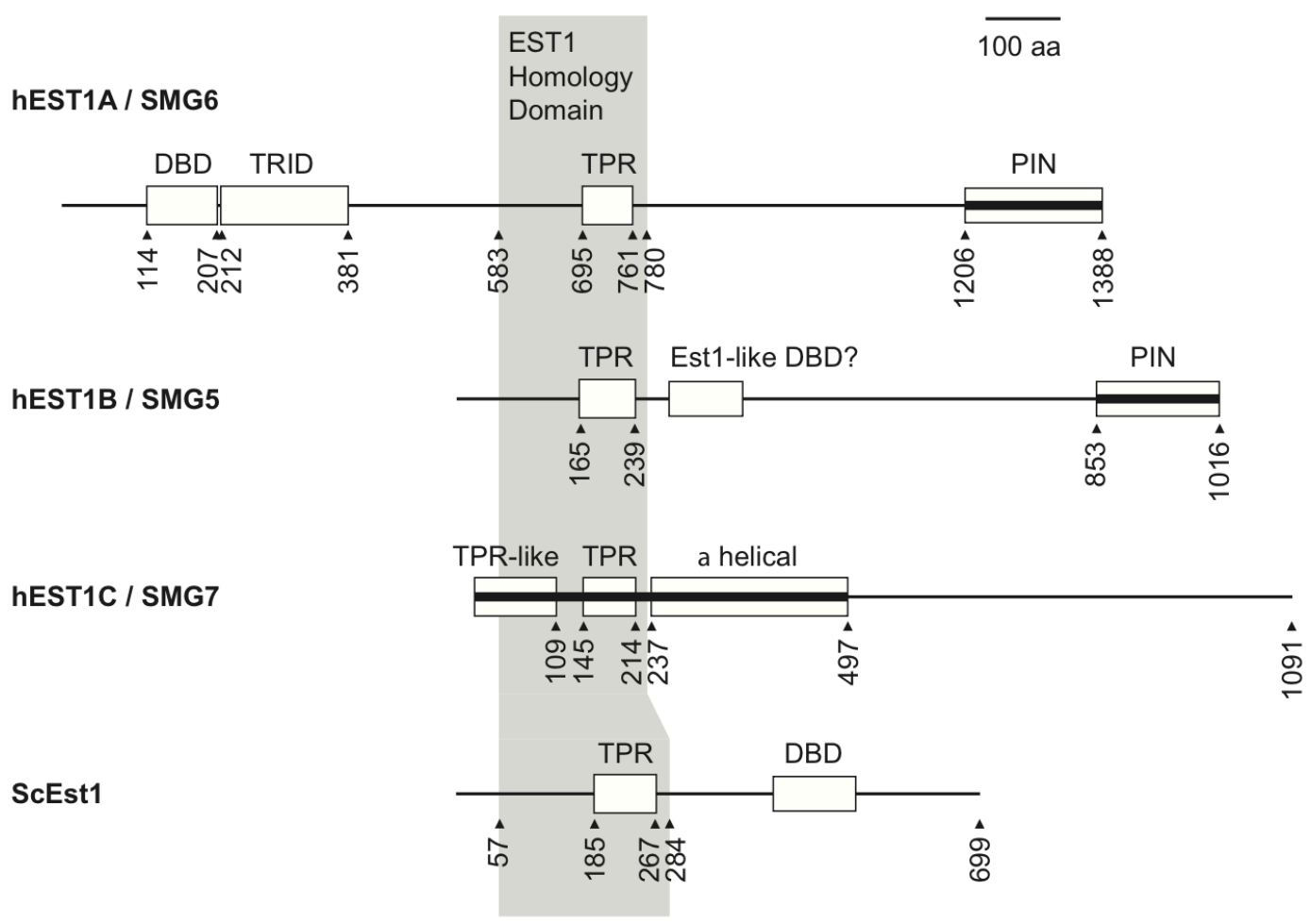

Figure 3.0: Representation of homology between human and S. cerevisiae Est1 gene. The area of highest homology is shown by the shaded area, which all contain TRP (tetratricopeptide). ScEst1 is the yeast genes and the three human homologs associated with it: hEST1A/SMG6, hEST1B/ SMG5 and hEST1C/SMG7. Figure adopted from Sealey and colleagues. ${ }^{122}$ PIN (PilT N-terminal), TRID (hTRinteraction domain), DBD (DNA binding domain).

This cross-species homology combined with the yeast genome project and yeast deletion libraries make the budding yeast one of the most valuable tools in studying eukaryotic life. As with the previous example, studying cellular processes in yeast can identify genes previously unknown in other eukaryotes and help identify their functions. This is also useful in studying human diseases with approximately 285 yeast proteins being homologous to 155 proteins associated in human disease, ${ }^{123}$ allowing drugs and other inhibitory molecules to be tested through methods such as chemical genetic screens to elucidate a potential mechanism of action. 


\subsection{The yeast pdr1 $\Delta p d r 3 \Delta x x x \Delta$ deletion mutant array}

Yeast $\mathrm{ABC}$ transporters are utilised in many biological processes including the regulation of mitochondrial function and peptide pheromone secretion, however, they are primarily used as xenobiotic efflux pumps conferring pleiotropic drug resistance (PDR). ${ }^{124,125}$ The presence of such effective efflux pumps allows the yeast to quickly adapt to toxic environmental changes as well as aiding in the protection against unwanted endogenous toxic metabolites. ${ }^{124}$ Although this aids in the viability of the yeast, many xenobiotic activities are masked by the pleiotropic drug resistant (PDR) efflux transporters resulting in reduced sensitivity when compared to mammalian cell lines. ${ }^{125}$ This limits the application of yeast in biological screens.

Therefore, the preparation of the $p d r 1 \Delta p d r 3 \Delta$ deletion library was undertaken by Coorey and colleagues, ${ }^{125}$ which involved the deletion of the genes for the two major transcription factors, $p d r 1 p$ and $p d r 3 p$ resulting in a pleiotropic drug resistant (PDR) network attenuated deletion mutant array. As shown in figure 3.1 many efflux pumps are tightly regulated through the pdr1p, pdr3p transcription factors. Much research has been conducted using the single deletion of the ABC transporter PDR5, ${ }^{126,127}$ however, the deletion of the pdr1p and $p d r 3 p$ transcription was found to give a greater hypersensitivity to a larger array of compounds as a reduction in all $\mathrm{ABC}$ efflux pumps was observed. ${ }^{125}$

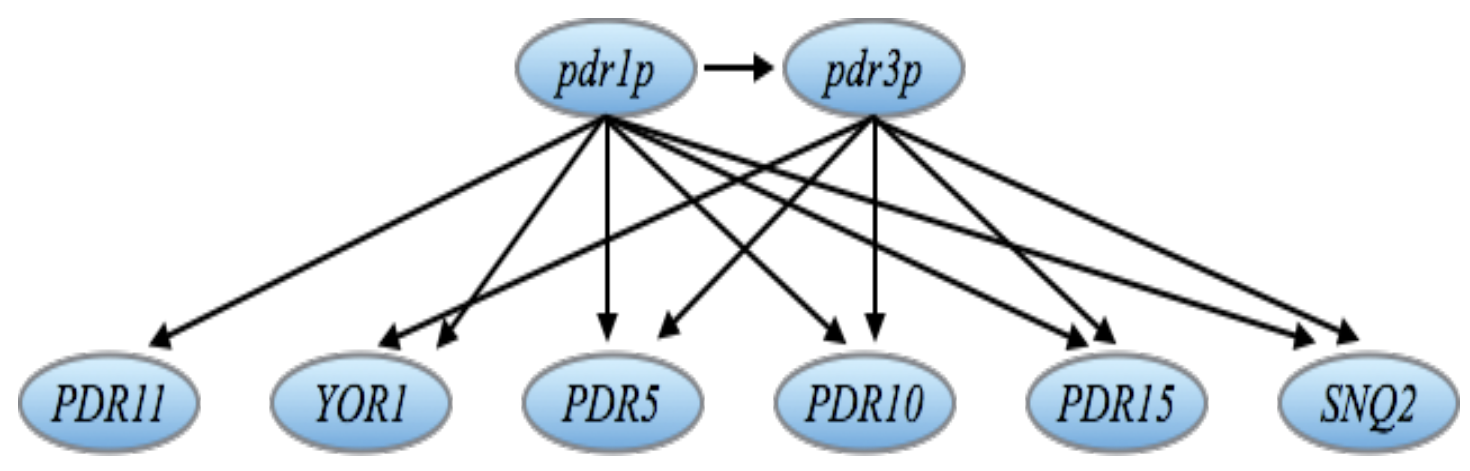

Figure 3.1: The PDR network in yeast are tightly regulated by the pdr1p and pdr3p transcription factors. Only the PDR ABC transporters are represented in this figure, however, it is worth noting more non-ABC transporters are involved in the PDR network however their functions are not well understood. Arrows indicate positive regulation. 
Preparation of the MATa $p d r l \Delta p d r 3 \Delta x x x \Delta$ library was completed through the mating of the MATa $p d r 1 \Delta p d r 3 \Delta$ double mutant with the MATa single gene deletion mutant array (DMA) gifted to Coorey and colleagues by Dr Charles Boone (University of Toronto). ${ }^{125}$ The $p d r 1 \Delta p d r 3 \Delta x x x \Delta$ deletion library was then subjected to a range of compounds including known pdr5p substrates. Previous compounds that displayed bioactivity in wild-type yeast were now found to cause hypersensitivity in the $p d r 1 \Delta p d r 3 \Delta$ deletion library whereas with the known pdr5p substrates bioactivity was now detectable. This indicated that the constructed $p d r 1 \Delta p d r 3 \Delta x x x \Delta$ deletion library was more sensitive to a broad range of xenobiotics, which in turn allowed for the elucidation of the mechanism of action of a wider range of xenobotic substances than could be achieved with the parental deletion library. ${ }^{125}$ 


\section{Materials and methods}

\subsection{Compounds}

All 1,2-cyclopropyl carbohydrates used in the biological screens were synthesised in this study (chapter 2), and were purified to $>95 \%$ as indicated through spectroscopic methods (1D and 2D NMR spectroscopy, IR spectroscopy). Samples were stored at $20{ }^{\circ} \mathrm{C}$ under nitrogen atmosphere, and stock solutions were freshly made at a concentration of $100 \mathrm{mM}$ in DMSO. All studies were completed using a single batch unless otherwise stated. Unless otherwise stated, all reagents were purchased from Sigma-Aldrich.

\subsection{Yeast strain}

Previous bioassays of $\mathbf{2 3}$ indicated appreciable potency only against yeast strains containing a $p d r 1 \Delta p d r 3 \Delta$ background. ${ }^{2}$ Chemical genetic profiling was undertaken using the $p d r 1 \Delta p d r 3 \Delta x x x \Delta$ library, which was obtained from a $-80{ }^{\circ} \mathrm{C}$ glycerol freezer stock originally prepared by Namal Coorey from the Chemical Genetics Laboratory, within the School of Biological Sciences at Victoria University of Wellington. ${ }^{125}$

\begin{tabular}{|c|c|}
\hline Strain & Genotype \\
\hline \multirow{2}{*}{$p d r 1 \Delta p d r 3 \Delta x x x \Delta$} & $\operatorname{pdr1} \Delta::$ NAT; $\operatorname{pdr} 3 \Delta::$ URA3; $\operatorname{xxx} \Delta:: \operatorname{kanR} ;$ can1 $\Delta::$ STE2pr- \\
& Sp_His5; Lyp1 $\Delta ;$ his3 $\Delta 1 ;$ leu2 $\Delta 0 ;$ ura3 $\Delta 0 ;$ met15 $\Delta 0$ LYS2 \\
\hline
\end{tabular}

\subsection{Yeast culture and growth conditions}

The $p d r 1 \Delta p d r 3 \Delta x x x \Delta$ yeast strains were cultured in one of the following three media conditions: synthetic complete media, synthetic drop-out miuns URA media and yeast peptone dextrose media, and supplemented with either of two antibiotics: ClonNat at a final concentration of $100 \mathrm{mg} / \mathrm{L}$ or geneticin (G418) a final concentration of 200 
$\mathrm{mg} / \mathrm{L}$. All media was sterilised via autoclave for $21 \mathrm{~min}$ at $124^{\circ} \mathrm{C}$ and $210 \mathrm{kPa}$. All yeast were grown under standard protocols as specified by Sherman. ${ }^{128}$

\subsubsection{Synthetic complete (SC) media}

For $800 \mathrm{~mL}$ of SC media, $1.36 \mathrm{~g}$ of yeast nitrogen base, without amino acids and ammonium sulfate (Formedium ${ }^{\mathrm{TM}} 1 \mathrm{td}$ ), $0.8 \mathrm{~g}$ of L-Glutamic acid monosodium salt hydrate (sigma Aldrich) and $1.6 \mathrm{~g}$ of the corresponding amino acid mix (see section 3.6.4) was added to $360 \mathrm{~mL}$ of distilled water $\left(\mathrm{dH}_{2} \mathrm{O}\right)$. The mixture was autoclaved at $124{ }^{\circ} \mathrm{C}$ for 21 min then allowed to cool before the addition of $40 \mathrm{~mL}$ of a $40 \%$ glucose solution in $\mathrm{dH}_{2} \mathrm{O}$ along with the appropriate antibiotic. $\mathrm{dH}_{2} \mathrm{O}$ is then added to make the solution up to $800 \mathrm{~mL}$. For solid SC agar, the same process is followed, with

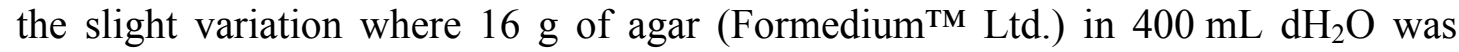
autoclaved and added to the SC mixture, making the total volume to $800 \mathrm{~mL}$. The agar must be kept at approximately $65^{\circ} \mathrm{C}$ otherwise it will begin to solidify.

\subsubsection{Synthetic drop-out (SD) minus URA media}

SD media is prepared in the same way as SC, though the amino acid mix used for this media does not contain uracil (URA).

\subsubsection{Yeast peptone dextrose (YPD) media}

For $800 \mathrm{~mL}$ of YPD media, $8 \mathrm{~g}$ of Bacto ${ }^{\mathrm{TM}}$ yeast extract (BD bioscience), $16 \mathrm{~g}$ of peptone (Formedium ${ }^{\mathrm{TM}} \mathrm{ltd}$ ) and $0.096 \mathrm{~g}$ of adenine (Sigma-Aldrich) was added to 360 $\mathrm{mL}$ of water and autoclaved at $124{ }^{\circ} \mathrm{C}$ for $21 \mathrm{~min}$. The solution was then allowed to cool before the addition of $40 \mathrm{~mL}$ of a $40 \%$ glucose solution in $\mathrm{dH}_{2} \mathrm{O}$, followed by the desired antibiotic. $\mathrm{dH}_{2} \mathrm{O}$ was then added to make the resulting solution up to $800 \mathrm{~mL}$. For the solid YPD agar, the same procedure is followed, with the addition of $16 \mathrm{~g}$ of agar (Formedium ${ }^{\mathrm{TM}} \mathrm{ltd}$ ) in $400 \mathrm{~mL}$ water to the YPD media after autoclaving to bring the total volume to $800 \mathrm{~mL}$. The solid agar was kept at $65{ }^{\circ} \mathrm{C}$ to prevent it from solidifying at lower temperatures before pouring plates. 


\subsubsection{Amino acid mix for SC media}

The amino acid mixture for SC media consists of; $3 \mathrm{~g}$ adenine, $2 \mathrm{~g}$ alanine, $0.2 \mathrm{~g} p$ aminobenzoic acid, $2 \mathrm{~g}$ asparagine, $2 \mathrm{~g}$ aspartic acid, $2 \mathrm{~g}$ cysteine, $2 \mathrm{~g}$ glutamic acid, 2 $\mathrm{g}$ glutamine, $2 \mathrm{~g}$ glycine, $2 \mathrm{~g}$ histidine, $2 \mathrm{~g}$ inositol, $2 \mathrm{~g}$ isoleucine, $10 \mathrm{~g}$ leucine, $2 \mathrm{~g}$ lysine, $2 \mathrm{~g}$ methionine, $2 \mathrm{~g}$ phenylalanine, $2 \mathrm{~g}$ proline, $2 \mathrm{~g}$ serine, $2 \mathrm{~g}$ threonine, $2 \mathrm{~g}$ tryptophan, $2 \mathrm{~g}$ tyrosine, $2 \mathrm{~g}$ uracil and $2 \mathrm{~g}$ valine. As stated above SD amino acid mix does not contain uracil, however everything else remains the same.

\subsection{Dose-response assay in Saccharomyces cerevisiae}

\subsubsection{Liquid phase dose-response assay}

All dose-response assays were conducted using a single colony of $p d r 1 \Delta p d r 3 \Delta h i s 3 \Delta$ yeast cells. Cells were inoculated into $2 \mathrm{~mL}$ of YPD and SC media. The inoculated cells were then placed in a rotating drum (Digisystem Laboratory Instruments) at $30{ }^{\circ} \mathrm{C}$ at a speed of $45 \mathrm{rpm}$ and left to grow overnight. Cell concentration was calculated using a UV/VIS spectrometer (Unicam 8625) reading at $\mathrm{OD}_{660}$. Cells were diluted with the respective media to make a $10 \mathrm{~mL}$ solution with a final cell concentration of $5 \times 10^{5}$ cells $/ \mathrm{mL}$. Using a multichannel pipette, $99 \mu \mathrm{L}$ of the cell solution was plated out into flat bottom 96 well plates (Corning Incorporated).

In a separate deep-well 96 well plate (Gene era biotech), a 1.5-fold serial dilution was prepared of compounds $23, \mathbf{5 4}, \mathbf{5 5}, \mathbf{5 6}, \mathbf{6 1}$ and $\mathbf{6 2}$ from the corresponding $100 \mathrm{mM}$ stock solution. Dilutions of the 1,2-cyclopropyl carbohydrates were achieved using DMSO (Sigma-Aldrich).

Subsequently $2 \mu \mathrm{L}$ of the 1.5 -fold drug dilution was added to each well of a 96 well microtiter plate containing the cell solution, making a final DMSO concentration of $2 \%$. A row was treated with $2 \mu \mathrm{L}$ of DMSO alone to act as a negative control to allow for the calculation of residual growth as well as the inclusion of an individual row containing only media in order to calculate optical density of the growth media. The 
plates were then mixed via vortex for 30 seconds at $1000 \mathrm{rpm}$ using an Eppendorf Mix Mate (Krackeler Scientific Inc.) and incubated at $31{ }^{\circ} \mathrm{C}$ for 24 hours. After 24 hours, the cells were re-suspended via vortex for 30 seconds at $1000 \mathrm{rpm}$ and the optical density read at $590 \mathrm{~nm}$ using a multi-well plate reader (PerkinElmer, Envision Multiplate Reader). Residual growth was calculated as:

$$
\frac{O D_{590} \text { exp }- \text { mean } O D_{590} \text { background }}{\text { mean } O D_{590} \text { control }- \text { mean } O D_{590} \text { background }} \times 100
$$

Where mean $\mathrm{OD}_{590}$ control is the mean optical density of the DMSO control wells, $\mathrm{OD}_{590}$ background is the mean optical density of wells containing only media and $\mathrm{OD}_{590}$ is the optical density for each experimental well.

\subsubsection{Solid phase dose-response assay}

A solid phase dose response was conducted using YPD agar. Based on the results of the liquid $\mathrm{IC}_{50}$ results (see section 3.17.1), seven falcon tubes were prepared for both 23 and 54 with a range of increasing drug concentrations of 0, 20, 50, 100, 200 and $400 \mu \mathrm{M}$ for $\mathbf{2 3}$ and $0,50,100,150,200$ and $300 \mu \mathrm{M}$ for 54, at a final DMSO concentration of $2 \%$. Hot agar $\left(55^{\circ} \mathrm{C}\right)$ was added to each falcon tube to a final volume of $30 \mathrm{~mL}$ and the solution was gently mixed through rotation. Each falcon tube was poured into separate Singer plates (Singer instruments, Somerset UK) and allowed to cool and set. Plates were not stacked to allow fast cooling and to avoid any potential breakdown of compound 23 and 54, as reported by Davies. ${ }^{2}$ Once cooled, a single plate from the $p d r 1 \Delta p d r 3 \Delta x x x \Delta$ library was pinned using the singer RoToR HAD (Alphatech systems Ltd) robot onto all the plates in a 1536 format resulting in quadruplicate colonies. The plates were incubated for 24 hours and then photographed. Colony size and circularity was calculated using the colony-based screening program Gitter. ${ }^{129}$ Results were compared to control, from which the residual growth could be calculated. 


\subsection{Chemical genetic screening}

All chemical genetic screens were conducted using the $p d r 1 \Delta p d r 3 \Delta x x x \Delta$ library. ${ }^{125}$ Excluded from the $p d r 1 \Delta p d r 3 \Delta x x x \Delta$ DMA are essential genes and 441 known slow growing deletion strains. The non-essential $p d r 1 \Delta p d r 3 \Delta x x x \Delta$ yeast DMA is composed of 14 plates, arranged in a 386 format, which include a $p d r 1 \Delta p d r 3 \Delta h i s 3 \Delta$ border to account for the effects of nutrition access on colony size. All plates were expanded to a 1536 format, allowing for quadruplicates of each colony.

Based on the results of the solid phase dose response assay (see section 3.17.2), 14 plates containing $40 \mathrm{~mL}$ of SC agar with no antibiotics were prepared with compound 23 at a concentration of $50 \mu \mathrm{M}(15 \mu \mathrm{L}$ from a $100 \mathrm{mM}$ stock solution in $285 \mu \mathrm{L}$ DMSO) to a final DMSO concentration of $1 \%$. This was repeated with $\mathbf{5 4}$ at a concentration of $160 \mu \mathrm{M}(48 \mu \mathrm{L}$ from a $100 \mathrm{mM}$ stock solution in $252 \mu \mathrm{L}$ DMSO). The solution containing the corresponding drug and DMSO was not added to the agar until the agar had cooled to approximately $55^{\circ} \mathrm{C}$. For each drug treatment, corresponding control plates were also poured using SC agar, which contained $300 \mu \mathrm{L}$ of DMSO. Plates were then allowed to set over 1 hour before drying in the laminar flow (Holten Lamin Air). Using the singer RoToR HDA the $p d r 1 \Delta p d r 3 \Delta x x x \Delta$ library was pinned from a previously prepared working copy onto the treated and controlled plates. A separate working copy was used for both 23 and 54 and their corresponding control plates. Plates were incubated at $33{ }^{\circ} \mathrm{C}$ and photographed at 18 , 22 and 36 hours. Images were processed by the colony-based screening program Gitter, ${ }^{129}$ where average circularity and size of each quadruplicate strain was calculated and compared against control. Results of the Gitter processing were run through a Screen Mill ${ }^{130}$ search resulting in a $p$-value and $z$-score for all quadruplicate colonies compared to control.

Resistant strains were defined as having a $p$-value less the 0.05 and a $z$-value (for the ratio of growth control/growth treatment) of -1.95 or less. Sensitive strains are defined as a $p$-value of 0.05 or less and a z-score (for the ratio of growth control/growth treatment) of greater than 1.95 . 


\subsection{Validation of chemical genetic screens}

Validations of both resistant and sensitive $p d r 1 \Delta p d r 3 \Delta x x x \Delta$ strains were conducted in liquid media. Results from the chemical genetic assay (section 3.18) indicated a large number of the resistant and sensitive deletion strains were the same for both compounds 23 and 54 suggesting both compounds have the same target. Therefore, resistant and sensitive strains were combined for the validation. A total of 169 resistant strains and 155 sensitive strains were inoculated into individual wells of four flat bottom 96 well plates (Corning Inc), containing $100 \mu \mathrm{L}$ of SD-URA liquid media. A single row containing only $p d r 1 \Delta p d r 3 \Delta h i s 3 \Delta$ was added on each plate as a control. Plates were placed on vortex for $30 \mathrm{sec}$ at $1000 \mathrm{rpm}$ and incubated at $33{ }^{\circ} \mathrm{C}$ for 48 hours until all strains were at saturation. Plates were then briefly vortexed for 30 seconds at $1000 \mathrm{rpm}$ and pinned using the singer RoToR HDA to four working copy of flat bottom 96 well plates containing $100 \mu \mathrm{L}$ of SD-URA. The new working copies were again placed upon the vortex for 30 seconds at $1000 \mathrm{rpm}$ and incubated for 48 hours at $33{ }^{\circ} \mathrm{C}$.

For compound 23, four flat bottom 96 well plates were prepared consisting of $99 \mu \mathrm{L}$ of SD-URA liquid media and $2 \mu \mathrm{L}$ of $\mathbf{2 3}$ in DMSO in each well, at a final concentration of $40 \mu \mathrm{M}$. Resistant and sensitive strains were then pinned from the previously prepared working copy using the singer RoToR HDA. Plates were placed upon the vortex for 30 seconds at $1000 \mathrm{rpm}$ and incubated at $33{ }^{\circ} \mathrm{C}$. Optical density measurements were then acquired at 24, 30, 36 and 48 hour time periods. The above process was repeated with compound 54 at a final concentration of $160 \mu \mathrm{M}$. For both compounds each resistant and sensitive plate was run with an untreated control plate with final DMSO concentration of $2 \%$. Resistant strains were defined as having residual growth 4 standard deviations above the residual growth $p d r 1 \Delta p d r 3 \Delta h i s 3 \Delta$ strain. Sensitive strains were defined in a similar manner, in which residual growth was 2 standard deviations below the $p d r 1 \Delta p d r 3 \Delta h i s 3 \Delta$ strains. Slow growing control strains were identified as having $40 \%$ reduction in growth compared to the mean control colony size and were subsequently excluded from the data. 
Gene ontology analysis was conducted on all validated strains utilising both yeastmine $^{131,132}$ and g:Profiler. ${ }^{133,134}$

\subsection{Mammalian cell experiments}

PhD candidate Richard Little, in the School of Biological Sciences, Victoria University of Wellington, conducted the following mammalian MTT cell proliferation experiments.

Under normal cell culture conditions, human HL-60 promyelocytic leukemia cells at a concentration of $1 \times 10^{4}$ cells/well were seeded into a 96 well plate and incubated with 23 for 48 hours. Cell were then treated with $20 \mu \mathrm{L}$ of MTT and left to incubate for a further 2 hours at $37{ }^{\circ} \mathrm{C}$. Addition of $100 \mu \mathrm{L}$ of a solubilising agent containing $45 \%$ DMF and 10\% SDS (pH 4.5, adjusted with acetic acid addition) allowed for the solubilisation of the blue crystals overnight at $37^{\circ} \mathrm{C}$. Absorbance readings at $570 \mathrm{~nm}$ indicated MTT reduction. $\mathrm{IC}_{50}$ values were calculated from a concentration-response curve using prism (Prism Graphpad Software Inc).

\subsection{Affinity matrix synthesis}

Epoxy-activated agarose $(600 \mathrm{mg}, 12 \mu \mathrm{M})$ was added to $2 \mathrm{~mL}$ of $\mathrm{dH}_{2} \mathrm{O}$ in a $15 \mathrm{~mL}$ falcon tube and allowed to swell for 2 hours. Sodium azide $(6 \mathrm{mg}, 90 \mu \mathrm{M})$ was then added to the solution and stirred lightly via vortex, followed by the addition of cerium (III) chloride heptahydrate $(1.4 \mathrm{mg}, 5.4 \mu \mathrm{M})$. The solution was rotated for 16 hours at $33{ }^{\circ} \mathrm{C}$. The solution was then centrifuged at $2000 \mathrm{rpm}$ for $1 \mathrm{~min}$ followed by the removal of the solvent. Purification was achieved by the successive addition of ethanol and diethyl ether, where ethanol $(6 \mathrm{~mL})$ was added and the solution and lightly shaken via vortex for $1 \mathrm{~min}$ before being centrifuged at $1000 \mathrm{rpm}$ for $1 \mathrm{~min}$. The solvent was removed and replaced with diethyl ether $(6 \mathrm{~mL})$. This was again shaken lightly via vortex and centrifuged at $1000 \mathrm{rpm}$ for $1 \mathrm{~min}$ before being decanted off. The whole process was then repeated to ensure full conversions of epoxide to azide. The final white precipitate was then dried under vacuum. 


\subsection{Cell lysate preparation}

Glass beads ( $0.5 \mathrm{~mm}$ diameter, dnature Ltd) were soaked in a solution of $1 \mathrm{M} \mathrm{HCl}$ overnight followed by extensive rinsing with water to ensure the $\mathrm{pH}$ was neutral. The glass beads were dried under vacuum at $80{ }^{\circ} \mathrm{C}$ overnight and chilled in ice before use. A $p d r 1 \Delta p d r 3 \Delta h i s 3 \Delta$ yeast colony was inoculated into a $15 \mathrm{~mL}$ solution of SD-URA and allowed to shake overnight at $33^{\circ} \mathrm{C}$. The $15 \mathrm{~mL}$ yeast culture was centrifuged for 2 min at 20,000 rpm and the supernatant was decanted off. The pdr1 $\Delta p d r 3 \Delta h i s \Delta$ culture was resuspended in $2 \mathrm{~mL}$ or lysis buffer $(50 \mathrm{mM}$ Tris- $\mathrm{HCl} \mathrm{pH} 8.0,150 \mathrm{mM}$ $\mathrm{NaCl}, 1 \% \mathrm{DMSO}$ and $10 \mu \mathrm{L}$ of protease inhibitor cocktail). Chilled glass beads were added to the solution at a ratio of $3 \mathrm{~g}$ per gram of yeast cell (wet weight). The solution was then shaken at full speed via vortex 5 times for 3 min, keeping the cells on ice for 2 min between vortex sessions. The glass beads were removed via pipette and the cellular debris was removed through centrifugation at $4{ }^{\circ} \mathrm{C}$ for $30 \mathrm{~min}$ at $16,000 \mathrm{rpm}$.

\subsection{Copper-assisted azide-alkyne cycloaddition}

From a prepared stock solution of $61(100 \mathrm{mM})$ in DMSO, $40 \mu \mathrm{L}$ was added to a $1 \mathrm{~mL}$ solution of prepared yeast lysate (section 3.12). The solution was allowed to shake for 6 hours at $33{ }^{\circ} \mathrm{C}$ before the addition of $25 \mathrm{mg}$ of azide-activated agarose matrix (section 3.11), $0.1 \mathrm{~mL}$ of saturated copper sulfate and $5 \mathrm{mg}$ of ascorbic acid neutralised in aqueous sodium hydroxide. The reaction mixture was left to shake at $33{ }^{\circ} \mathrm{C}$ for 12 hours before undergoing centrifugation at 7,000 rpm for $5 \mathrm{~min}$. The supernatant was decanted providing the derivatised matrix, which was washed three times with a buffer solution ( $1 \mathrm{M}$ Tris- $\mathrm{HCl}$ buffer $\mathrm{pH}$ 8), centrifuging at 7,000 rpm for 5 min and decanting the supernatant between each wash. The above method was repeated with the exclusion of the saturated copper sulfate and ascorbic acid solution as a control. 


\subsection{Isolation of binding proteins}

A $500 \mu \mathrm{L}$ low salt wash solution $(0.1 \%$ triton $\mathrm{X}-100$ in $0.5 \mathrm{M}$ Tris- $\mathrm{HCl} \mathrm{pH} 7.6)$ was added to the lysate-matrix complex for both the treatments and negative control (section 3.12) and resuspended. The solution was then centrifuged for $5 \mathrm{~min}$ at $7,000 \mathrm{rpm}$ and the supernatant decanted, followed by the addition of a $500 \mu \mathrm{L}$ high salt wash solution $(1 \mathrm{M} \mathrm{NaCl}, 0.1 \%$ triton $\mathrm{X}-100$ in $0.5 \mathrm{M}$ Tris- $\mathrm{HCl} \mathrm{pH} 7.7)$. The solution was shaken via vortex, centrifuged at $7,000 \mathrm{rmp}$ for $5 \mathrm{~min}$ and the supernatant was removed. An LDS wash was performed with the addition of $100 \mu \mathrm{L}$ of NuPAGE LDS sample buffer (4X) loading buffer. The solution was again shaken via vortex and centrifuged at 7,000 rpm for $2 \mathrm{~min}$ and the supernatant was collected. The lysate-matrix complex was then washed twice with $\mathrm{dH}_{2} \mathrm{O}$ and twice with a buffer solution (100 mM aqueous ammonium bicarbonate) with the last buffer wash lasting $10 \mathrm{~min}$. The washes were centrifuged at 7,000 pm for $5 \mathrm{~min}$ and supernatant decanted. The lysate-matrix complex was then reduced with a $100 \mu \mathrm{L}$ solution of $10 \mathrm{mM}$ DTT in $100 \mathrm{mM}$ ammonium bicarbonate at $30{ }^{\circ} \mathrm{C}$ for $30 \mathrm{~min}$ then allowed to cool to room temperature before the addition of $1 \mu \mathrm{L}$ of a $1 \mathrm{M}$ solution iodoacetamide to make a final concentration of $10 \mathrm{mM}$. The solution was incubated for $30 \mathrm{~min}$ at $35^{\circ} \mathrm{C}$ with no exposure to light, followed by centrifugation $(7,000 \mathrm{rpm}, 5 \mathrm{~min})$ and removal of supernatant before the lysate-matrix complex was washed with $50 \%$ acetonitrile in $100 \mathrm{mM}$ ammonium bicarbonate buffer. The resulting solution was centrifuged (7,000 rpm, $5 \mathrm{~min})$ and the supernatant decanted. The matrix was then rehydrated in $20 \mu \mathrm{L}$ of $50 \mathrm{mM}$ ammonium bicarbonate, followed by the addition of $1 \mu \mathrm{g}$ of trypsin and incubated overnight at $33{ }^{\circ} \mathrm{C}$. The solution was centrifuged $(7,000 \mathrm{rpm}, 5 \mathrm{~min})$ and the supernatant was collected and concentrated via speed vac to afford the peptides.

\subsection{ZipTip purification}

The concentrated peptides were resuspended in $10 \mu \mathrm{L}$ of a $0.2 \%$ formic acid solution. For the preparation of the ZipTip (Millipore Corp.), $10 \mu \mathrm{L}$ of a $0.2 \%$ formic acid solution was aspirated twice. Care was taken to not pass any air through the ZipTip. The sample was then aspirated $10 \mathrm{X}$ followed by $2 \mathrm{X}$ aspiration with $10 \mu \mathrm{L}$ of a $0.2 \%$ 
formic acid solution then $10 \mathrm{X}$ aspiration with a 1:1 formic acid:acetonitrile solution. Utilising the same ZipTip, this procedure was repeated ensuring binding of all the peptides onto the ZipTip followed by the final aspiration in $70 \%$ acetonitrile solution. The 1:1 formic acid:acetonitrile solution was then added to the $70 \%$ acetonitrile solution and concentrated via speed vac to yield the purified isolated peptides. The procedure was then repeated with the control sample.

\subsection{Protein identification}

Following protein puficication and isolation, identification was undertaken utilising either liner ion trap (LTQ) spectroscopy (LTQ XLTM Linear Ion Trap Mass Spectrometer, Thermofischer), or MALDI (AB SCIEX TOF/TOFTM 5800).

\subsubsection{LTQ tandem mass spectroscopy}

Samples were prepared by resuspending the purified peptides in $50 \mu \mathrm{L}$ of formic acid buffer $(0.1 \%$ conc. formic acid in HPLC water). Ionisation of the peptide solution was conducted by electrospray with a silica tip emitter (360 $\mu \mathrm{m}$ OD X $20 \mu \mathrm{m}$ ID X $10 \mu \mathrm{m}$ tip opening, New objectives, USA), with a set voltage potential of $1.8 \mathrm{kV}$, a heat capillary set to $275^{\circ} \mathrm{C}$, and a tube lens at $120 \mathrm{~V}$ allowed the positive ions to enter. Ions with a mass to range of $200-1850 \mathrm{~m} / \mathrm{z}$ were analysed in a 6 hour acquisition time utilising Fourier transform mass spectroscopy (FTMS) in the orbitrap. At a resolution of 30,000, a full scan in the FTMS identified the 6 top intensity ions were selected for collision-induced dissociation (CID) and detection in the LTQ. The following dynamic exclusion criteria were as stated: repeat duration $30 \mathrm{~s}$, repeat counts 2 , exclusion duration $90 \mathrm{~s}$, exclusion list size 500 .

\subsubsection{MALDI spectroscopy}

Preparation of the MALDI matrix was undertaken via the addition of $500 \mu \mathrm{L}$ of acetonitrile, $500 \mu \mathrm{L}$ of MilliQ water and $1 \mu \mathrm{L}$ of concentrated trifluoroacetic acid (TFA). The solution was mixed via vortex before the addition of $10 \mathrm{mg}$ of alpha- 
cyano-4-hydroxycinnamic acid (CHCA). The solution was shaken at full speed via vortex followed by a centrifugation at $16,000 \mathrm{rpm}$ for $5 \mathrm{~min}$. The supernatant was decanted and used as matrix. A calibration mixture was also prepared consisting of $1 \mu \mathrm{L}$ of CalMix 2 (Applied biosystems) in $100 \mu \mathrm{L}$ of the matrix solution.

The purified isolated peptides from treatment and control samples (see section 3.13) were resuspended in $10 \mu \mathrm{L}$ of MilliQ water. A series of dilutions were made to a total volume of $6 \mu \mathrm{L}$ consisting of a 1:1, 5:1 and 10:1 matrix:sample solution. The dilutions and their corresponding controls were each added as individual spots on the MALDI detection plate at a volume of $1 \mu \mathrm{L}$. The corresponding calibration spot was also added. The prepared plate was allowed to dry.

Calibration was internally conducted utilising CalMix2 monoisotopic peaks of adrenocorticotropic hormone (ACTH) clip 7-38 ( $\mathrm{m} / \mathrm{z}$ 3657.9294), ACTH clip 18-39 ( $m / z$ 2465.1990), АCTH clip 1-17 ( $/ 2 / z$ 2093.0870), angiotension 1 ( $m / z$ 1296.6770) and des-Arg1-brodykinin ( $m / z$ 904.4680). Criteria of calibration included a minimum of three matched peaks, mass tolerance of $\pm 0.1 \mathrm{~m} / \mathrm{z}$, signal to noise ratio $\geq 5$ and a outlier error of $1 \mathrm{~m} / \mathrm{z}$. The spectrum was acquired through a positive reflector mode. Laser intensity was fixed at 4600 and a pulse range of $400 \mathrm{~Hz}$. A total of 500 laser shots were taken and peptide fragments were collected in a mass rage of 700 to 4000 Da. MS/MS sequence was imported into the ProteinPilot ${ }^{\mathrm{TM}}$ (Sciex) software. The generated peak list was sequence was analysed with the MASCOT algorithm (Matrix science) generating a peak list, which was run against the NCBI database for S. cerevisiae generating a list of isolated proteins. 


\section{Results}

\subsection{Dose-response assay in Saccharomyces cerevisiae}

\subsubsection{Liquid phase dose-response assay}

Previously established results by Davies ${ }^{2}$ indicated no bioactivity of compound $\mathbf{2 3}$ and other 1,2-cyclopropyl carbohydrates in the haploid wild-type yeast strain BY4741. However bioactivity of the 1,2-cyclopropyl carbohydrates synthesis by Davies was reported in the $p d r 1 \Delta p d r 3 \Delta x x x \Delta$ strain due to the deletion in the $p d r l p$ and $p d r 3 p$ efflux pumps. Therefore all dose-response assays conducted during this study were undertaken using the $p d r 1 \Delta p d r 3 \Delta h i s 3 \Delta$ strain as a surrogate for a wild type in the $p d r 1 \Delta p d r 3 \Delta x x x \Delta$ library. A liquid growth assay (section 3.7) was used in order to establish an inhibitory concentration of compounds $23,54,55,61$ and 62 . As shown in figure 3.2, inhibition of growth over a 24 hour period for compound $\mathbf{2 3}$ was recorded with an $\mathrm{IC}_{50}$ value of $20.4 \mu \mathrm{M}$. The recorded $\mathrm{IC}_{50}$ value varies slightly from that reported by Davies $(44 \mu \mathrm{M}){ }^{2} \mathrm{IC}_{50}$ values were calculated from triplicate data and determined through fitting a sigmoidal curve from the dose response data. A maximal cell death was reported at $60.14 \mu \mathrm{M}$ as shown in figure 3.2.

Dose-response 23

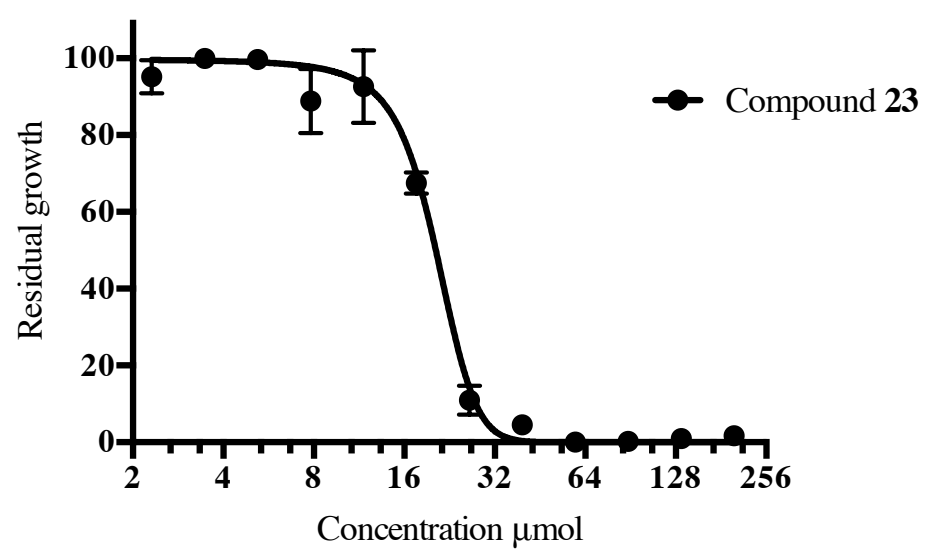

Figure 3.2: Compound 23 dose-response assay. $\mathrm{IC}_{50}$ values of sensitised $p d r 1 \Delta p d r 3 \Delta h i s \Delta$ strain yeast to compound 23 were measured over a 24 hour period. The triplicate data was fitted by a sigmoidal curve and presented through a dose- response curve. Error bars represent standard error of the mean. 
Of the 1,2-cyclopropyl carbohydrate library tested by Davies, ${ }^{2}$ inhibitory effects were only noted in compounds containing the $\alpha$-cyclopropyl ring. However, this was not the case in this study as inhibitory effects were observed in both the $\alpha$ - and $\beta$ stereoisomers of the 1,2-cyclopropyl carbohydrates (54 and 55) as well as (61 and 62), although, greater inhibition was observed in the $\alpha$ stereoisomers (54 and 61) compared to the $\beta$ isomer. As shown in figure 3.3, both compounds 54 and 61 still inhibit in the low $\mu \mathrm{M}$ range, though a noticeable increase in $\mathrm{IC}_{50}$ is observed compared to compound 23, with the calculated $\mathrm{IC}_{50}$ for 54 and 61 being $148 \mu \mathrm{M}$ and $110 \mu \mathrm{M}$, respectively. $\mathrm{IC}_{50}$ were again recorded from triplicate data and calculated through the fitting of a sigmoidal curve (figure 3.3). All results were recorded at a 24 hour time point. Comparison of inhibition of compounds 54 and 55, and 61 and 62 are demonstrated in figure $3.4 \mathrm{~A}$ and $3.4 \mathrm{~B}$, respectively. It is worth noting that the increase in the residual growth demonstrated in figure 3.4 at higher concentrations is due to the precipitation of the compounds 54, 55, 61 and 62 in the liquid agar. Formation of the cloudy precipitate is noticeable immediately upon addition of the inhibitor.
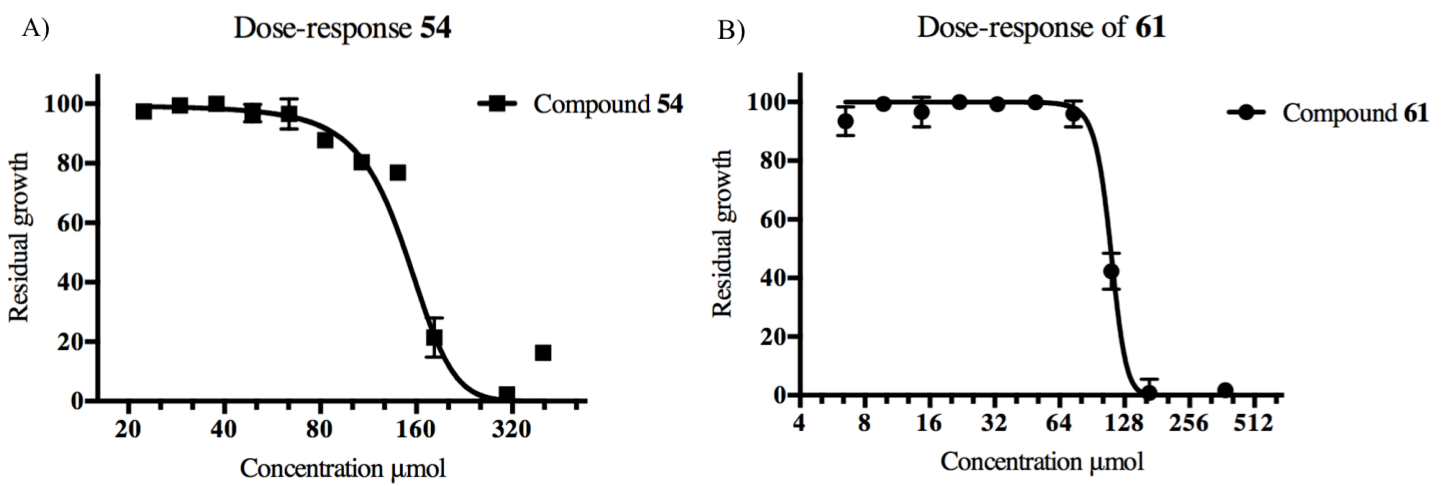

Figure 3.3: Dose-response assay for both compound 54 (A) and 61 (B). IC $_{50}$ values of sensitised pdr1 1 pdr3 3 his $3 \Delta$ strain yeast to compound 54 and $\mathbf{6 1}$ were measured over a 24 hour period. The triplicate data was fitted by a sigmoidal curve and presented through a dose- response curve. Error bars represent standard error of the mean. 

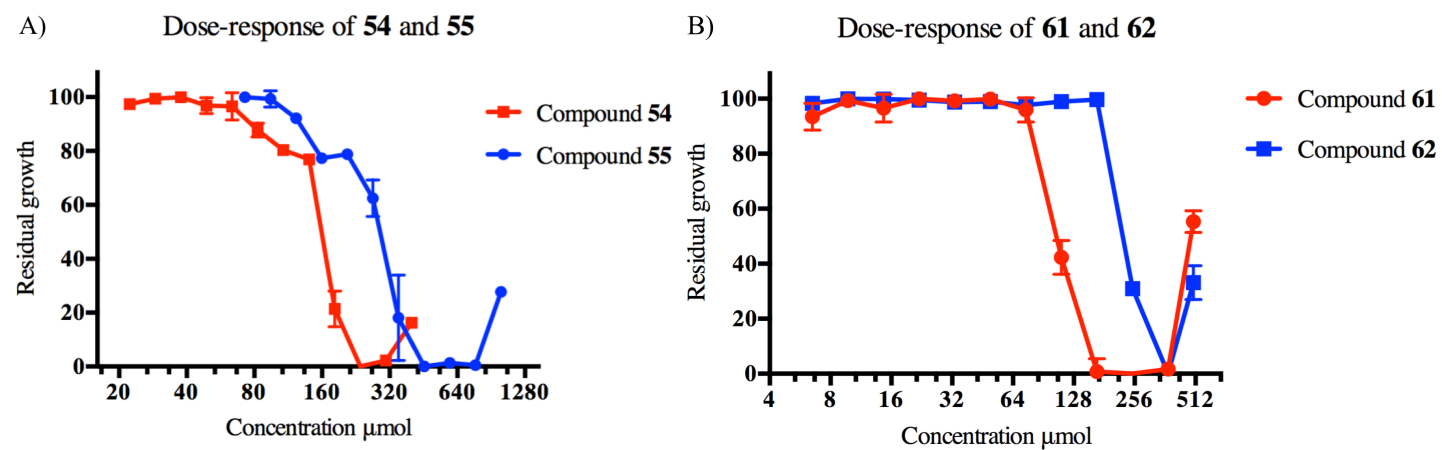

Figure 3.4: A) Comparison of compounds 54 and 55, indicating a prominent increase in the $\mathrm{IC}_{50}$ of the $\beta$ product (55) compared to the $\alpha$ (54). B) Comparison of compounds 61 and 62, indicating a prominent increase in the $\mathrm{IC}_{50}$ of the $\beta$ product (62) compared to the $\alpha(\mathbf{6 1})$. Results are consistent with similar trends observed by Davies. Error bars show standard error of the mean.

\subsubsection{Solid phase dose-response}

A solid phase dose-response was conducted in order to establish the necessary dose required in the chemical genetic screen. A solid phase dose-response was only conducted on compounds $\mathbf{2 3}$ and $\mathbf{5 4}$ as these compounds displayed a low $\mathrm{IC}_{50}$ in the liquid dose-response. Due to limitations in the amount of compound, 61 did not undergo a solid dose-response and a chemical genetic analysis. Results shown in figure 3.5 are consistent with that of the liquid dose-response showing inhibition by both compounds. The treated plates were photographed at 24 hours and the images were processed to determine average circularity and colony size. Average circularity and colony sizes were then compared to the negative control and residual growth was calculated to determine the respective $\mathrm{IC}_{50}$ values. Solid phase inhibition at 24 hours of compounds 23 and 54 resulted in an $\mathrm{IC}_{50}$ values of $52.2 \mu \mathrm{M}$ and $158.5 \mu \mathrm{M}$, respectively (figure 3.5). This data was not repeated in triplicates due to low compound amounts. Again, a small increase in the residual growth of compound $\mathbf{2 3}$ is noticeable at $200 \mu \mathrm{M}$ and $300 \mu \mathrm{M}$, which is due to the precipitation of the compound within the agar when the plates are poured. 


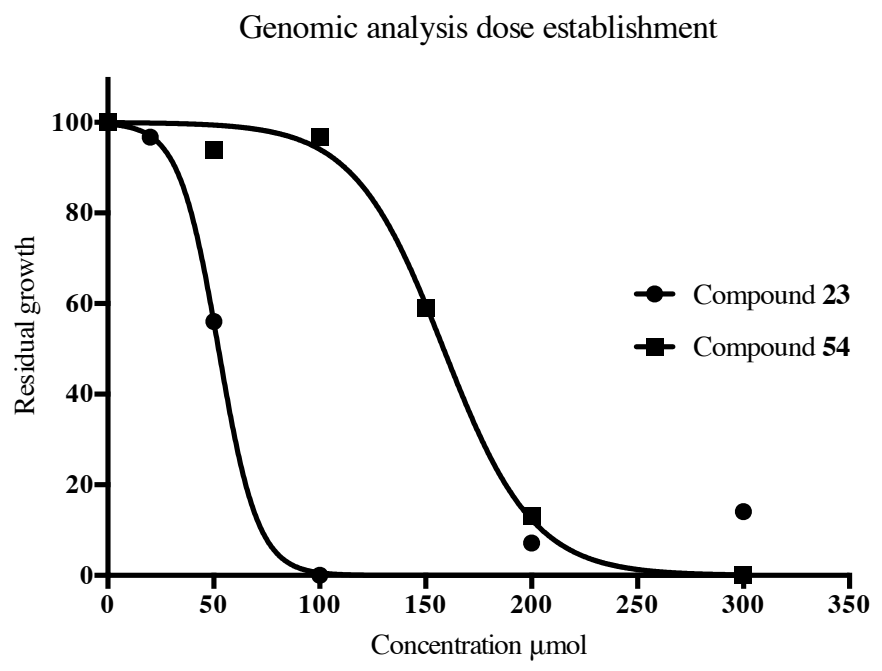

Figure 3.5: Solid phase dose-response of compound 23 and $\mathbf{5 4}$ indication $\mathrm{IC}_{50}$ values of $52.2 \mu \mathrm{M}$ and $158.5 \mu \mathrm{M}$ respectively. Data was not repeated in triplicates therefore standard error of the mean was not calculated. $\mathrm{IC}_{50}$ was calculated by fitting a sigmoidal curve.

\subsection{Chemical genetic screens}

Using the $p d r 1 \Delta p d r 3 \Delta x x x \Delta$ deletion mutant library of $S$. cerevisiae, a high-throughput synthetic genetic array was conducted with compounds 23 and $\mathbf{5 4}$. This would allow for the identification of any chemical genetic interactions and ideally identification of a mechanism of action of both compounds. From the solid phase dose response (section 3.17.2), an inhibitory concentration of both compounds 23 and 54 was selected that would give approximately a $50 \%$ reduction in growth. This would allow for the identification of both sensitive and resistant strains. The $p d r 1 \Delta p d r 3 \Delta x x x \Delta$ library was expanded from 384 colonies to the 1536 colony format to produce quadruplicates of each strain, with each plate containing a $p d r 1 \Delta p d r 3 \Delta h i s 3 \Delta$ border, which acts as a proxy wild-type strain. The his 3 deletion is neutral in the growth media and the $p d r 1 \Delta p d r 3 \Delta h i s 3 \Delta$ strain has a common genetic background with the rest of the library bearing a full set of deletion markers. The deletion library was photographed at 24, 36 and 48 hours and the images were processed allowing for the determination of both colony size and circularity. ${ }^{129}$ As shown in figure 3.6, resistant 
strains were defined by an increase in growth with a $p$-value of $>0.05$ and a z-score of $<-1.95$ (for the ratio of growth control/growth treatment) against the negative control. Of the 4800 homozygous deletion strains tested, 132 were resistant against compound 23 and 83 strains were found to be resistant against compound 54. In addition, sensitive strains were defined as having a decreased growth with a $p$-value of $>0.05$ and a z-score of $>1.95$ (for the ratio of growth control/growth treatment) against the control. This identified 67 strains sensitive to compound $\mathbf{2 3}$ and 106 strains sensitive to compound 54 (Figure 3.6). Identification of both resistant and sensitive strains allowed for early speculation of potential mechanisms of actions of both compounds. An early gene ontology analysis indicated enrichment among the resistant strain for cytoplasmic translation with a $p$-value of $2.17 \times 10^{-6}$ and 0.018 for both compounds 23 and 54, respectively. Ontology was found among the sensitive strains with corresponding $p$-values of 0.001 and 0.01 respectively for compounds $\mathbf{2 3}$ and $\mathbf{5 4}$, which indicated a degree of involvement in protein folding in the endoplasmic reticulum (ER). Due to both compounds identifying similar resistant and sensitive strains as well as having matching ontology results, they were assumed to have the same target. However identified strains were validated before definitive conclusions can be made, as high-throughput techniques are susceptible to false positive and negative results.
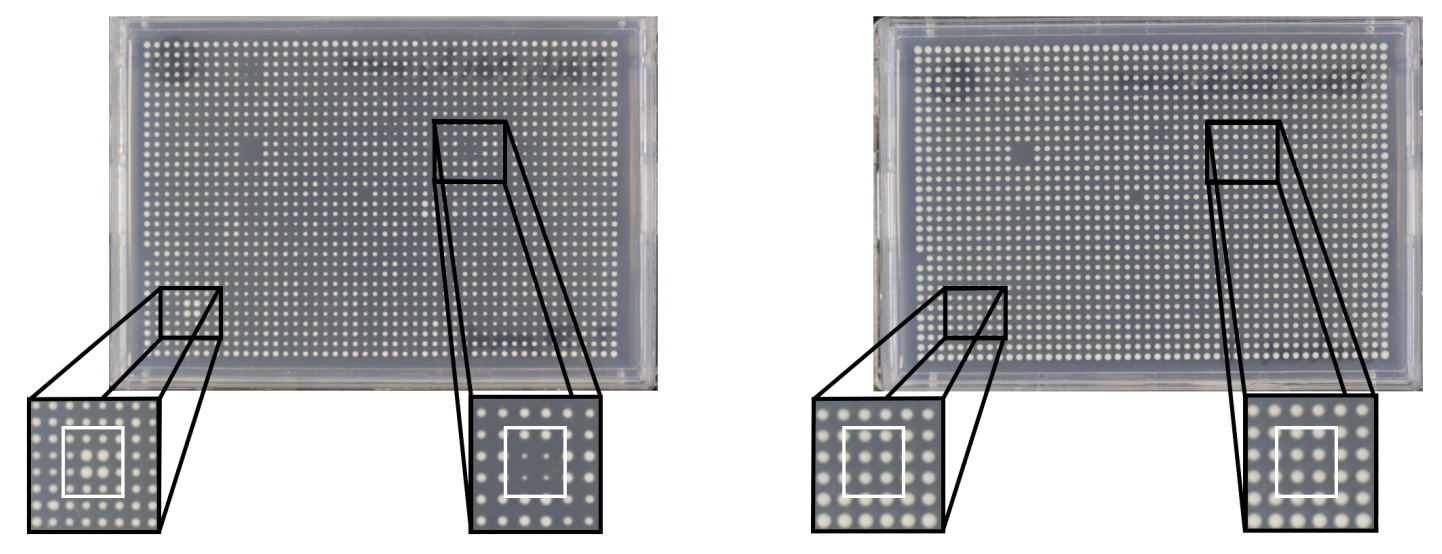

Figure 3.6: Example of a single plate (plate 8) from the homozygous $p d r 1 \Delta p d r 3 \Delta x x x \Delta$ deletion mutant library, screened against $\mathbf{2 3}$, indicating both a resistant and sensitive strain compared to control (right plate). Each plate contains 306 deletion strains in quadruplicate colonies with a pdr1 $\Delta p d r 3 \Delta h i s 3 \Delta$ boarder around the edge of the plate acting as proxy wild-type strain. 


\subsection{Validation of chemical genetic hits}

A number of factors in the high-throughput screens can lead to false positive or negative results. Variation in the amount of yeast collected during pinning, competition for nutrients with neighboring colonies and inherently fast or slow growing strains are all factors that can lead to errors in chemical genetic arrays. It was therefore decided to conduct the validations in liquid SD-URA media in order to eliminate some of these potential error-producing factors and to ensure sensitivity and resistance was robust across different growth media. Due to the similarities in the identified sensitive and resistant strains of both compounds 23 and $\mathbf{5 4}$ in the genomic screens, and the hypothesis that both compounds are hitting the same target, all identified hits were combined for validation. Therefore, a total of 168 resistant and 151 sensitive strains were chosen for validation against both compounds.

For these validations, resistant strains were defined as having a residual growth 4 standard deviations greater than the average $\Delta$ his control. Slow growing strains were identified as having a $40 \%$ in the control stain compared to the mean control OD. This identified 61 resistant strains for compound $\mathbf{2 3}$ and 12 resistant strains for compound 54 (Appendix, table 4.0). Gene ontology analysis showed significant interactions of both 23 and 54. Utilising a Holm-Bonferroni test correction, enrichment of the cytosolic ribosome to a significant $p$-value of 0.019 for compound 23 was noted (table 3.0). However, with compound 54, ontology enrichment was shown both in the SNARE complex and SNAP receptor activity. Both enrichments were statistically significant, indicated by a $p$-value less than 0.05 utilising the Holm-Bonferroni test correction (table 3.1).

\begin{tabular}{|c|c|c|c|}
\hline \multicolumn{3}{|c|}{ Compound 23 Resistant } \\
\hline Ontology & Enrichment & P-value & \# of genes \\
\hline Biological process & - & - & - \\
\hline Cellular component & Cytosolic ribosome & $1.37 \times 10^{-7}$ & 11 \\
\hline Molecular function & - & - & - \\
\hline
\end{tabular}

Table 3.0: Gene ontology enrichments of resistant validated hits for compound 23. 


\begin{tabular}{|c|c|c|c|}
\hline \multicolumn{3}{|c|}{ Compound 54 Resistant } \\
\hline Ontology & Enrichment & P-value & \# of genes \\
\hline Biological process & - & - & - \\
\hline Cellular component & SNARE complex & $3.14 \times 10^{-3}$ & 3 \\
\hline Molecular function & $\begin{array}{c}\text { SNAP receptor } \\
\text { activity }\end{array}$ & $1.44 \times 10^{-2}$ & 3 \\
\hline
\end{tabular}

Table 3.1: Gene ontology enrichments of resistant validated hits for compound 54.

Additionally, sensitive strains were defined as having a residual growth 2 standard deviations below than the average $\Delta$ his control and again slow growing strains were identified as having a $40 \%$ in the control stain compared to the mean control OD. This allowed for the successful identification of 112 sensitive strains to compound $\mathbf{2 3}$ and 53 strains sensitive to compound 54 (appendix, table 4.1). Gene ontology analysis was again undertaken on the identified sensitive strains for both compounds 23 and $\mathbf{5 4}$. Analysis using a Holm-Bonferroni test correction of the sensitive strains identified by compound 23 showed enrichment in protein folding in the endoplasmic reticulum, along with a large assortment of enrichments in the cellular process of the ER (table 3.2). Despite slightly varied results in compound $\mathbf{5 4}$ when compared to $\mathbf{2 3}$, there were also noticeable similarities. Enrichment was found in intra-golgi vesicle-mediated transport utilising a Holm-Bonferroni test correction for both compounds. Interestingly, the same assortment of enrichments relating to the ER was found for $\mathbf{5 4}$ as they were for 23 (table 3.3). It is worth noting that gene ontology terms are "nested", containing parental and daughter terms. Thus the list of enrichments shown in table 3.0, 3.1, 3.2, 3.3 and 3.4 include such nested terms and are found because of overlapping sets of sensitive deletion strains. 


\begin{tabular}{|c|c|c|c|}
\hline Ontology & Enrichment & P-value & \# of genes \\
\hline Biological process & Protein folding in endoplasmic reticulum & $1.15 \times 10^{-2}$ & 5 \\
\hline \multirow[t]{9}{*}{ Cellular component } & Endoplasmic reticulum part & $3.60 \times 10^{-7}$ & 26 \\
\hline & Endomembrane system & $3.96 \times 10^{-7}$ & 40 \\
\hline & Endoplasmic reticulum & $5.02 \times 10^{-7}$ & 29 \\
\hline & $\begin{array}{l}\text { Endoplasmic reticulum membrane protein } \\
\text { complex }\end{array}$ & $5.65 \times 10^{-6}$ & 5 \\
\hline & Endoplasmic reticulum membrane & $4.93 \times 10^{-5}$ & 5 \\
\hline & $\begin{array}{l}\text { Nuclear outer membrane-endoplasmic } \\
\text { reticulum membrane network }\end{array}$ & $9.20 \times 10^{-5}$ & 22 \\
\hline & $\begin{array}{l}\text { Integral component of endoplasmic } \\
\text { reticulum membrane }\end{array}$ & $6.15 \times 10^{-3}$ & 8 \\
\hline & $\begin{array}{l}\text { Intrinsic component of endoplasmic } \\
\text { reticulum membrane }\end{array}$ & $6.15 \times 10^{-3}$ & 8 \\
\hline & Bounding membrane of organelle & $1.71 \times 10^{-2}$ & 30 \\
\hline
\end{tabular}

Table 3.2: Gene ontology interaction of sensitive validated hits for compound 23.

\begin{tabular}{|c|c|c|c|}
\hline Ontology & Enrichment & $\mathrm{P}$-value & \# of genes \\
\hline Biological process & Intra-Golgi vesicle-mediated transport & $2.45 \times 10^{-2}$ & 5 \\
\hline \multirow[t]{10}{*}{ Cellular component } & Endoplasmic reticulum part & $7.19 \times 10^{-6}$ & 17 \\
\hline & Endomembrane system & $9.40 \times 10^{-7}$ & 26 \\
\hline & Endoplasmic reticulum & $3.55 \times 10^{-5}$ & 18 \\
\hline & $\begin{array}{l}\text { Endoplasmic reticulum membrane protein } \\
\text { complex }\end{array}$ & $9.89 \times 10^{-3}$ & 3 \\
\hline & Endoplasmic reticulum membrane & $1.21 \times 10^{-4}$ & 15 \\
\hline & $\begin{array}{l}\text { Nuclear outer membrane-endoplasmic } \\
\text { reticulum membrane network }\end{array}$ & $1.92 \times 10^{-4}$ & 7 \\
\hline & $\begin{array}{l}\text { Integral component of endoplasmic } \\
\text { reticulum membrane }\end{array}$ & $6.21 \times 10^{-4}$ & 7 \\
\hline & $\begin{array}{l}\text { Intrinsic component of endoplasmic } \\
\text { reticulum membrane }\end{array}$ & $6.21 \times 10^{-4}$ & 7 \\
\hline & Bounding membrane of organelle & $8.89 \times 10^{-6}$ & 24 \\
\hline & Organelle membrane & $1.51 \times 10^{-3}$ & 25 \\
\hline
\end{tabular}

Table 3.3: Gene ontology interaction of sensitive validated hits for compound $\mathbf{5 4}$. 
Following the hypothesis that compounds $\mathbf{2 3}$ and $\mathbf{5 4}$ are targeting the same receptor, resistant and sensitive strains were compared between the compounds and common validated strains were better evaluated, as they were believed to represent the the most robust chemical genetic interactions. The common hits between 23 and 54 were subjected to a gene ontology analysis and the results are indicated in table 3.4. Unfortunately, no enrichment was found for the common resistant strains.

\begin{tabular}{|c|c|c|c|}
\hline Ontology & Enrichment & P-value & \# of hits \\
\hline \multirow[t]{8}{*}{ Biological process } & intra-Golgi vesicle-mediated transport & $8.08 \times 10^{-3}$ & 5 \\
\hline & Macromolecule localisation & $1.11 \times 10^{-2}$ & 18 \\
\hline & Cellular protein localisation & $1.53 \times 10^{-2}$ & 14 \\
\hline & Cellular macromolecule localisation & $2.52 \times 10^{-2}$ & 14 \\
\hline & Protein localisation & $2.60 \times 10^{-2}$ & 16 \\
\hline & Intracellular protein transport & $2.84 \times 10^{-2}$ & 12 \\
\hline & Cellular localisation & $3.54 \times 10^{-2}$ & 18 \\
\hline & Protein transport & $4.85 \times 10^{-2}$ & 14 \\
\hline \multirow[t]{12}{*}{ Cellular component } & Endomembrane system & $9.17 \times 10^{-8}$ & 15 \\
\hline & Bounding membrane of organelle & $1.132 \times 10^{-5}$ & 24 \\
\hline & Endoplasmic reticulum part & $1.31 \times 10^{-5}$ & 15 \\
\hline & Endoplasmic reticulum membrane & $3.87 \times 10^{-5}$ & 3 \\
\hline & Endoplasmic reticulum & $3.96 \times 10^{-5}$ & 16 \\
\hline & $\begin{array}{l}\text { Nuclear outer membrane-endoplasmic } \\
\text { reticulum membrane network }\end{array}$ & $6.00 \times 10^{-3}$ & 14 \\
\hline & Organelle membrane & $9.01 \times 10^{-4}$ & 6 \\
\hline & $\begin{array}{l}\text { Integral component of endoplasmic } \\
\text { reticulum membrane }\end{array}$ & $2.82 \times 10^{-3}$ & 6 \\
\hline & $\begin{array}{l}\text { Intrinsic component of endoplasmic } \\
\text { reticulum membrane }\end{array}$ & $2.82 \times 10^{-3}$ & 21 \\
\hline & $\begin{array}{l}\text { Endoplasmic reticulum membrane protein } \\
\text { complex }\end{array}$ & $5.13 \times 10^{-3}$ & 22 \\
\hline & Golgi transport complex & $1.42 \times 10^{-2}$ & 3 \\
\hline & Membrane & $2.17 \times 10^{-2}$ & 29 \\
\hline
\end{tabular}

Table 3.4: Gene ontology for the common sensitive hits between $\mathbf{2 3}$ and $\mathbf{5 4}$. 
A manual analysis of the validated resistant and sensitive hits showed a high number of gene involved in specific protein complexes, as shown in table 3.5. For example all but one EMC gene of the EMC complex was defined as sensitive after the validations indicating a strong interaction with the complex. Similar results were obtained for other complexes (table 3.5). Where possible members of the complexes shown in table 3.5 that were not tested were all subjected to hypothesis testing in order to assess their sensitivity to compounds 23 and $\mathbf{5 4}$. This allows for the testing of potential false negatives from the high-throughput genetic screening in method 3.8 .

\subsection{Hypothesis testing of non-validated strains}

Where several members of a protein complex had been identified through the initial screen and validated, it was hypothesised that these complexes were important in the mode of action of the compounds. This hypothesis was tested through assessment of further members of each complex. Hypothesis testing was undertaken utilising the same methodology as the validation assay in order to reduce any potential variation in data. The hypothesis testing was run coherently with randomly selected strains from the $p d r 1 \Delta p d r 3 \Delta x x x \Delta$ deletion mutant library, that were previously defined as not resistant or sensitive in order remove any potential biases in the results. By utilising the same parameters as the validation experiments, several of the genes previously untested in the complexes in table 3.5 were validated and defined as sensitive. This added further weight for the importance of the complexes in the mechanism of action of compounds $\mathbf{2 3}$ and 54. Randomly selected strains that were included as a negative control showed no sign so sensitivity. 


\begin{tabular}{|c|c|c|c|}
\hline Complex & Member & Validation & Hypothesis testing \\
\hline \multirow[t]{6}{*}{ EMC } & EMC1 & 23 & \\
\hline & EMC2 & 23 and 54 & \\
\hline & EMC3 & 23 and 54 & \\
\hline & EMC4 & 23 & \\
\hline & EMC5 & Not tested & 23 and 54 \\
\hline & EMC6 & 23 and 54 & \\
\hline \multirow[t]{8}{*}{$\mathrm{COG}$} & COG1 & Not tested & Not in deletion library \\
\hline & COG2 & Not tested & Null mutant inviable \\
\hline & COG3 & Not tested & Not in deletion library \\
\hline & COG4 & Not tested & Null mutant inviable \\
\hline & COG5 & 23 and 54 & \\
\hline & COG6 & Not tested & 23 and 54 \\
\hline & COG7 & 23 and 54 & \\
\hline & COG8 & 23 and 54 & \\
\hline \multirow[t]{4}{*}{ GARP } & VPS51 & 23 and 54 & \\
\hline & VPS52 & Not tested & Not in deletion library \\
\hline & VPS53 & 23 and 54 & \\
\hline & VPS54 & Not tested & Not in deletion library \\
\hline \multirow[t]{3}{*}{ Sec63 Complex } & SEC62 & Not tested & Null mutant inviable \\
\hline & SEC66 & 23 and 54 & \\
\hline & SEC72 & Not tested & 23 \\
\hline \multirow[t]{3}{*}{ SSH1 complex } & SSH1 & 23 and 54 & \\
\hline & SBH2 & 23 & 23 and 54 \\
\hline & SSS1 & Not tested & Null mutant inviable \\
\hline
\end{tabular}

Table 3.5: Potential complexes involved in the mechanism of action of both $\mathbf{2 3}$ and $\mathbf{5 4}$ showing validated hits and hypothesis tested hits to respective protein complex.

\subsection{Mammalian cell experiments}

Compound $\mathbf{2 3}$ was subjected to MMT assay by $\mathrm{PhD}$ candidate, Richard Little, who utilised the HL-60 human promyelocytic leukemia cell line to conduct initial doseresponse assays. As shown in figure 3.7, inhibition of growth was observed over a 48 hour period with a maximal inhibition dose of $76 \mu \mathrm{M}$. Utilising triplicate data and 
the best fitted sigmoidal curve, the $\mathrm{IC}_{50}$ value was calculated to be $24 \mu \mathrm{M}$. Although mammalian cells tend to be more sensitive to small molecules due to their lack of $P D R$ efflux pumps, these results are consistent with the $\mathrm{IC}_{50}$ value reported in the yeast liquid dose-response. It is important to note that the perceived increase in survival at a higher concentration of approximately $400 \mu \mathrm{M}$ is again due to the precipitation of compound $\mathbf{2 3}$ and not an increase in cell viability.

MTT HL-60 assay of 23

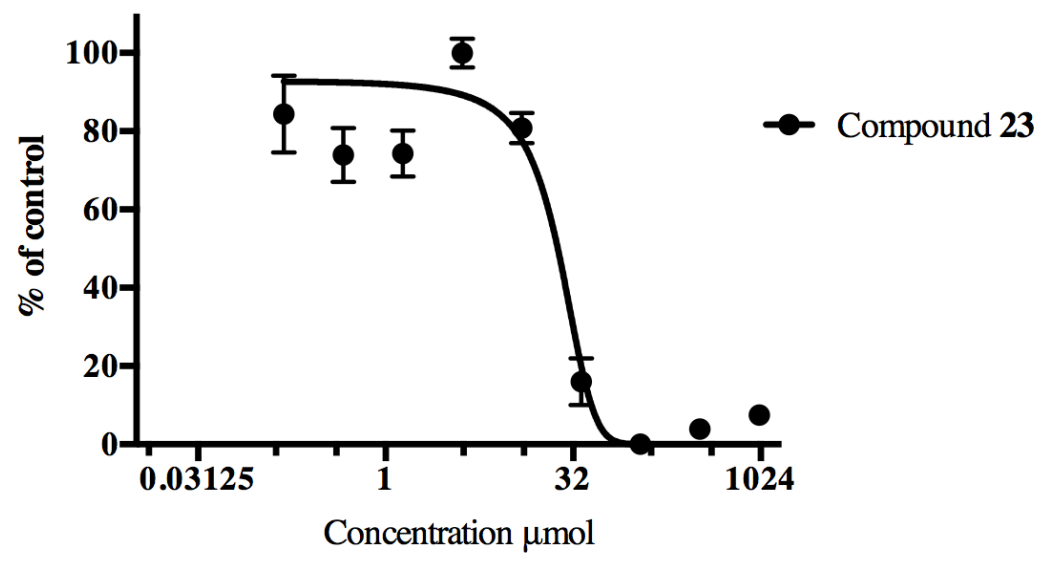

Figure 3.7: Dose-response assay of HL-60 mammalian cell line to compound 23 measured over a 48 hour period. The triplicate data was fitted by a sigmoidal curve a. Error bars represent standard error of the mean.

\subsection{Protein isolation and identification via affinity purification}

As the dose-response results (section 3.17.1) demonstrated bioactivity of the propargyl derivative 61, a chemical proteomic analysis was undertaken in order to attempt to elucidate the potential target for the bioactive compounds synthesised in chapter 2. Both linear ion trap (LTQ) and MALDI-TOF mass spectroscopic methods were used in this study. 


\begin{tabular}{|c|c|c|c|c|c|c|}
\hline Description & Score & Coverage & Proteins & $\begin{array}{l}\text { Unique } \\
\text { peptides }\end{array}$ & Peptides & \#AA \\
\hline $\begin{array}{l}\text { Fructose-bisphosphate } \\
\text { aldolase }\end{array}$ & 31.1 & $8.36 \%$ & 1 & 2 & 2 & 359 \\
\hline $\begin{array}{l}\text { Glyceraldehyde-3-phosphate } \\
\text { dehydrogenase }\end{array}$ & 15.55 & $9.34 \%$ & 3 & 1 & 3 & 332 \\
\hline Enolase & 14.17 & $11.90 \%$ & 2 & 2 & 6 & 437 \\
\hline $60 \mathrm{~S}$ ribosomal protein & 10.43 & $5.39 \%$ & 1 & 1 & 2 & 297 \\
\hline Phosphoglycerate kinase & 10.08 & $8.17 \%$ & 1 & 1 & 3 & 416 \\
\hline Heat shock protein SSA2 & 6.31 & $9.23 \%$ & 2 & 2 & 3 & 639 \\
\hline Phosphoglycerate mutase & 5.27 & $7.29 \%$ & 1 & 1 & 2 & 247 \\
\hline Pyruvate kinase & 5.26 & $6.40 \%$ & 1 & 2 & 3 & 500 \\
\hline 40S ribosomal protein & 3.97 & $11.76 \%$ & 2 & 1 & 1 & 136 \\
\hline Elongation factor & 2.69 & $2.40 \%$ & 1 & 1 & 1 & 458 \\
\hline
\end{tabular}

Table 3.6: Results from the LTQ mass spectrometer. Although results were recorded the low score and low protein coverage does not make these results significant, therefore no observations were made.

Analysis of the results from the LTQ mass spectroscopy was undertaken using Thermo fisher Proteome Discoverer 1.4.1.14, which yielded several identified proteins as shown in table 3.6. However all hits had scores below those considered meaningful. These low quality assignments were based off low percentage coverage of the protein as identifications were made from a very small number of peptides. For example the top result as determined by Thermo fisher Proteome Discoverer was Fructose-bisphosphate aldolase, which had the highest score of 31.1 although identification was made from two peptides with covered $8.36 \%$ of the peptide. This is not sufficient to identify the protein as a target, and most likely relates to a small amount of contamination in the sample.

Analysis of the MALDI results by protein pilot ${ }^{\mathrm{TM}}$ program and MASCOT algorithm yielded one potential match, the YAL028W-like protein, however this was also associated with a low score of 26 , with only 4/108 peptide fragment matches. Therefore this data is also not significant and no observations were made. 


\section{Discussion}

The decision to undergo biological analysis utilising the $p d r 1 \Delta p d r 3 \Delta$ DMA library was made based on the previous findings reported by Davies, ${ }^{2}$ which indicated 1,2cyclopropyl carbohydrates were potentially active substrates for ATP-binding cassette $(\mathrm{ABC})$ efflux transporters. The general amphiphilicity of the 1,2-cyclopropyl carbohydrates synthesised by Davies was consistent with that of efflux substrates. To this end, Davies screened a small library of 1,2-cyclopropyl carbohydrates against the yeast wild-type strain BY4741, which resulted in no bioactivity, however, identical test runs against the $p d r 1 \Delta p d r 3 \Delta$ deletion library yielded toxicity in the mid to low micromolar concentration range, which was promising.

\subsection{Dose response in relation to chemical structure}

As stated in section 1.4.1, it was proposed that due to the high ring and torsional strain of the cyclopropane moiety and its $\mathrm{sp}^{2}$-like characteristics, 1,2-cyclopropyl carbohydrates would undergo either a ring opening or expansion reaction if exposed to an enzymatic nucleophile, allowing for a mechanism-based inhibition of a putative target enzyme. Through a number of SAR assays with a small library of 1,2cyclopropyl carbohydrates, Davies ${ }^{2}$ was able to postulate a potential mechanism of inhibition. For example, positioning good leaving groups at either the C-7 or C-3 position resulted in very little to no bioactivity, deeming ring expansion reactions shown in scheme 3.1 to be unlikely. 


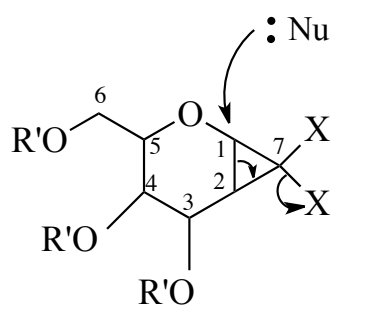

19

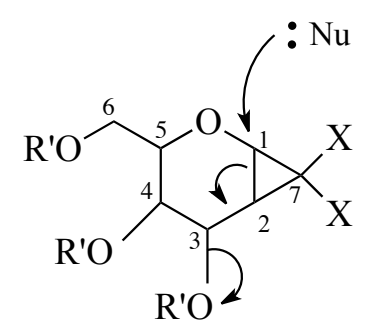

21<smiles>[R20]C[C@H]1OC([Y])=C([R])C([R20])C=C1[Y]</smiles>

20

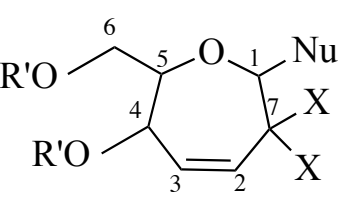

22

Scheme 3.1: Unlikely ring expansion mechanisms.

In contrast, synthesised compounds with the ability to stabilise a C-7 carbanion consistently showed bioactivity, suggesting ring opening reactions as a mechanism of inhibition as shown in scheme 3.2. This led to the proposed design of the new lead compound 54, where the formation of an enolate anion (81b) was envisaged to occur leading to an increase stabilisation through resonance with $\mathbf{8 1 a}$ and favoring the ring opening reaction. As expected, the synthesised target compounds in chapter 2 exhibited inhibition of $p d r 1 \Delta p d r 3 \Delta$ yeast strain in the low micromolar concentration range, adding further weight that the compounds undergo a ring opening reaction and formation of a carbanion. Disappointingly, however, the $\mathrm{IC}_{50}$ values of the newly synthesised compounds were higher then the original compound 23. This was envisaged to be due to unfavourable non-covalent interactions within the binding pocket. Moreover, the substitution of the electronegative chlorine for an alkyl chain could result in unfavourable hydrophobic interactions within the binding pocket, resulting in the increased $\mathrm{IC}_{50}$ value. Nonetheless, observed bioactivity of all synthesised compounds was consistent with ring opening and carbanion stabilisation. The proposed mechanism shown in scheme 3.2 is thought to be the most likely mechanism of inhibition. 


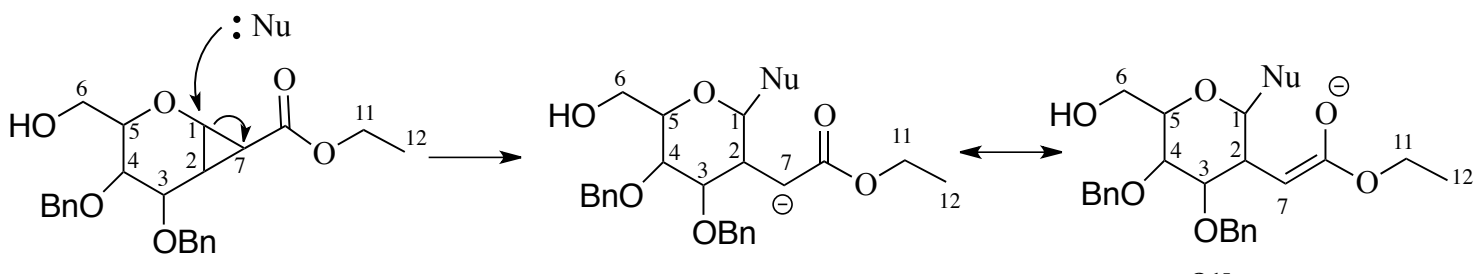
54

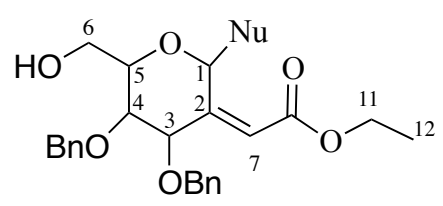

83

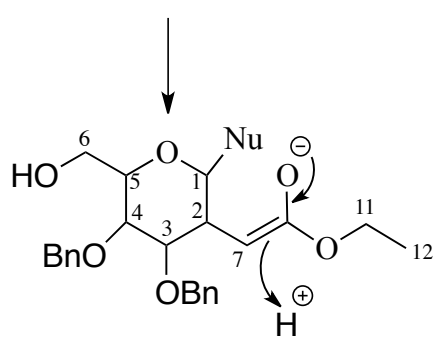

82

Scheme 3.2: Proposed mechanism of inhibition of compound 54.

As demonstrated by Davies ${ }^{2}$, the stereochemistry of the cyclopropane ring also has an important effect on the biological activity of the compounds, with bioactivity being reported only for the compounds with the cyclopropyl ring on the $\alpha$-face on the pyranose ring. Although in this study bioactivity was reported for both the $\alpha$ - and $\beta$ cyclopropyl compounds synthesised in chapter 2 , a substantial reduction in bioactivity was observed in the $\beta$ diastereoisomers compared to the $\alpha$ diastereoisomers. This suggested that either a steric interaction reduces the ability of the $\beta$ diastereoisomers to access the active site of the target leading to a lower bioactivity, or that the stereochemistry of the $\beta$ diastereoisomers interferes with either the enzymatic nucleophilic attack or the ability for the enzyme to aid in the stabilisation of the C-7 carbanion. As shown in figure 3.8, if an enzymatic nucleophile attacks the anomeric carbon from the $\beta$-face on the pyranose ring, the steric bulk of the cyclopropane and the attached substituents in the $\beta$ isomer may hinder the nucleophilic attack from occurring, leading to a reduced affinity of the compound. Much like the positioning of the enzymatic nucleophile preference may also be imposed through the positioning of a catalytic residue within the binding site, which aids in the stabilisation of the C-7 carbanion. Irrespective of which of these effects underlies the facial preference, it is clear that a diastereoselective preference is consistent with a target based activation of 
the compound. An example demonstrating a similar situation was reported by Todoroki and colleagues, ${ }^{135}$ where the correct stereochemistry cyclopropane ring on the plant hormone abscisic acid was essential in eliciting bioactivity. Through the synthesis of several derivatives of abscisic acid and extensive biological testing, they conclude that the cyclopropane must be in the 'down' orientation due to the tight sterics of the binding site. ${ }^{135}$

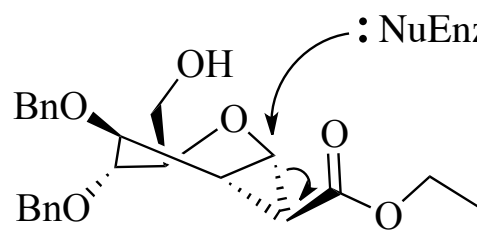

$54=\alpha$

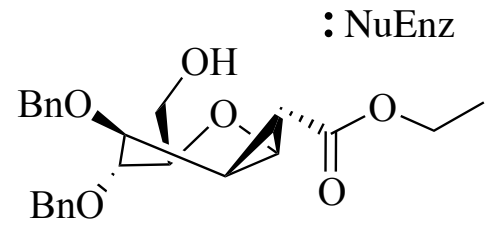

$55=\beta$

Figure 3.8: Enzymatic nucleophilic attack from the $\beta$ face, as a proposed reason for decreased bioactivity of the $\beta$ diastereoisomers.

As expected, the dose response of compound 56 gave no bioactivity, which was consistent with the results reported by Davies. ${ }^{2}$ This negative result adds further weight that the $\mathrm{C}-6 \mathrm{OH}$ is an essential pharmacophores element for the bioactivity of the synthesised compounds. This suggests that non-covalent interactions such as a hydrogen bond acceptor may be present within the binding pocket in close proximity to the C-6 OH. However, the lack of bioactivity may also be due to the larger steric bulk of the formate ester, preventing the compound from accessing the enzyme's active site.

It is important to note that although the results are consistent with the possibility that the synthesised 1,2-cyclopropyl carbohydrates are substrates for an enzymatic nucleophilic attack, it remains conceivable that the inhibition could be occurring through strictly non-covalent interactions or that nucleophilic attack is occurring via an activated water molecule. ${ }^{136}$ 


\subsection{Chemical genetic analysis}

Investigation into the potential mechanism of compounds $\mathbf{2 3}$ and $\mathbf{5 4}$ through the use of chemical genetic profiling resulted in some fascinating outcomes, which allowed for the speculation of potential pathways and even targets involved in the activity of both compounds. The initial chemical genetic screen using the $p d r 1 \Delta p d r 3 \Delta \mathrm{xxx} \Delta$ DMA library ${ }^{125}$ yielded a total of 132 resistant strain and 67 sensitive strains for compound 23 and 87 resistant and 106 sensitive strain for compound 54. However due to the potential errors that can arise from high-throughput screening all identified strain were subjected to validation in order to identify potential false positive results. As stated in section 3.19, it was assumed that both compounds had a common target due the similarities in the resulting chemical genetic profiles. Therefore all genes identified as a 'hit' in the chemical genetic screens were combined in the validation and run against compounds 23 and 54. The validation screens included randomly selected strains, which were not identified as a 'hit' in the high-throughput screens as negative controls.

Identification of the sensitive and resistant strains allowed for the analysis of biological and cellular enrichment through gene ontology. Although no enrichment was found for the common resistant genes, several processes were found to be significant for the sensitive strains with the general theme for protein localisation and trafficking associated with the endoplasmic reticulum and golgi (for the full ontology enrichments see, table 3.4). The common validated results also underwent further analysis with the Biological Networks Gene Ontology (BiNGO) tool which is an open-source Java application that determines which gene ontologies are significantly overexpressed. ${ }^{137}$ This allowed for further analysis of the data indicating over representation of genes in specific pathways along with the graphical representation of the data (figure 3.9). As shown in figure 3.9, although significant enrichment is associated with such processes as protein folding in the endoplasmic reticulum and cellular calcium ion homeostasis, the overwhelming majority of enrichment is in protein localisation and intracellular transport, verifying the results from the initial ontological screens. 


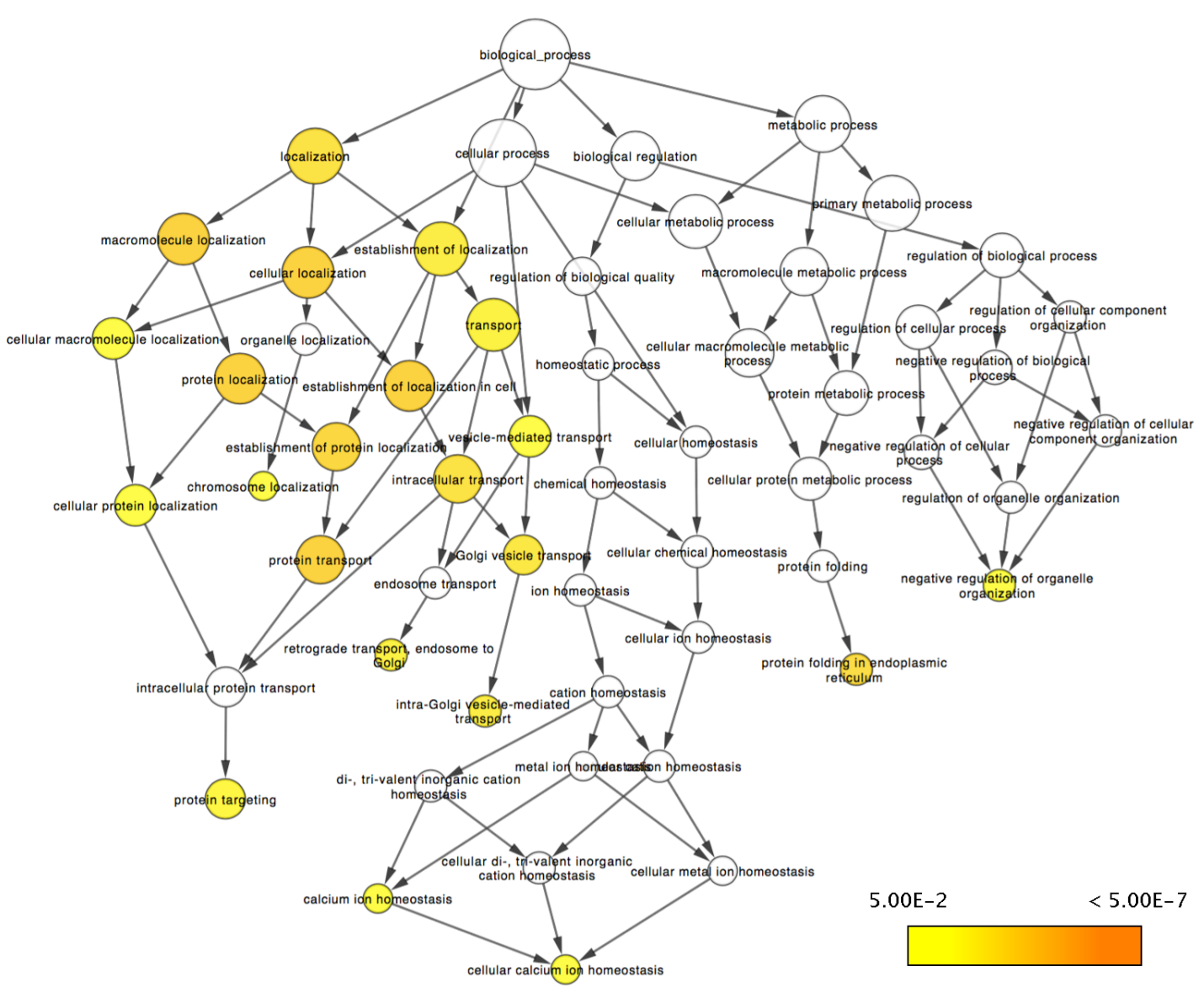

Figure 3.9: BiNGO analysis of the common validated sensitive strains indicated an over representation of genes involved in protein localisation and intracellular transport.

However although both gene ontology and BiNGO analysis indicated the potential mechanism of action of compounds $\mathbf{2 3}$ and $\mathbf{5 4}$ being involved in protein localisation and intracellular transport, further work needed to be done to narrow the parameters in which inhibition may be occurring. Therefore a manual analysis of the common validated hits was undertaken in order to identify the potential involvement of specific protein complexes in the mechanism of compounds 23 and $\mathbf{5 4}$. As shown in table 3.5, five protein complexes were found to display sensitivity to both compounds.

Analysis of the complexes shown in table 3.5 leads to a speculative hypothesis of a potential mechanism of action of compounds 23 and 54. The initial aim was to attempt to identify a set of essential genes that are not in the deletion library with a 
paralog complex that would be identified as sensitive. With chemical genetic interactions, partial inhibition of the essential complex at a low concentration, i.e $\mathrm{IC}_{50}$, level would lead to reduced growth of all colonies however the strain with the gene deletion in the paralog complex or associated pathways would exhibit hypersensitivity to the compound indicating the essential complex as a potential target.

Of the complexes shown in table 3.5 this was the case of the Sec61 complex. The Sec61 complex is essential for yeast viability, hence it is not in the deletion library, however, Sec61 is known to have a physical interaction with the Sec63 complex and it also has a paralog, the Ssh1 complex, both of which were found to be hypersensitive. The Sec61 complex is essential in protein translocation into the endoplasmic reticulum (ER) for both co- and post-translational translocation of protein. During co-translational translocation a signal recognising particle receptor (SRPR) recognises a specific signal recognising particle (SRP) at the amino terminal of the peptide within the translating ribosome. The SRPR transfers the ribosome to the Sec61 complex allowing he two complexes to directly bind in turn allowing translocation of the polypeptide through the Sec61 complex concurrently with the peptide synthesis (figure 3.10A). ${ }^{138,139}$ In contrast to co-translational translocation, post-translational translocation is the translocation of previously synthesised peptide from the cytosol to the ER. This requires the recruitment of the additional complex Sec63 and the Hsp70 chaperone protein $\mathrm{BiP},{ }^{140}$ to aid in the unidirectional movement of the proteins into the ER form the cytosol. Upon Sec61 recognition of the SRP on the polypepide, Sec63 recruits the BiP chaperone, which essentially pulls the polypeptide through the Sec61 complex and into the ER (Figure 3.10B). ${ }^{139}$ 


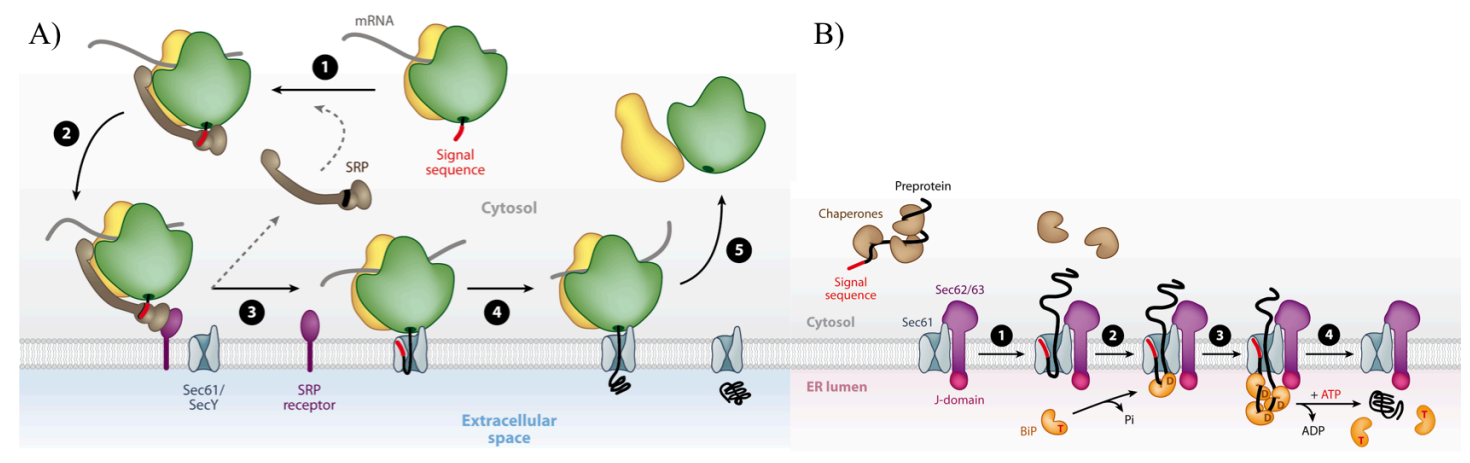

Figure 3.10: A) Co-translational translocation: SRPR binds to SRP on the ribosome. Binding of the ribosome directly to Sec61 releases the SRP-induced break on translation and allows translocation to occur concurrently with translation, B) posttranslational translocation: Translated polypeptide binds to Sec61 which recruits the Sec63 complex. The polypeptide is pulled through via Hsp70 chaperone protein BiP. Figure adopted from Park et al with permission from the publisher. ${ }^{139}$

In light of these results and findings Sec61 was identified as a potential target for compounds 23 and 54. The results from the chemical genetic screens and the validations also seem to match that reported by Junne and colleagus, ${ }^{141}$ who reported the isolation and discovery of a new natural product that directly inhibited the translocation complex Sec61. Due to only a small amount of their chemical genetic profile being published, the authors were contacted directly to see if similarities were present between both their data set and that presented in this thesis. However after examination of their data and correspondence with the authors few similarities were found reducing the probability of Sec61 as a potential target for 23 and $\mathbf{5 4}$. Consistent with this, analysis of the strains resistant to compound $\mathbf{2 3}$ shown enrichment in the cytosolic ribosome, suggesting that the reduction of translation into the ER causes resistance, most likely through reducing the build up of protein in the ER. This contradicts the suggestion of Sec61 complex as a potential target, as inhibition Sec61 would also slow translation and reduce the build up of protein in the ER giving similar results.

Analysis of the literature identified the use of both the GARP and the COG complexes in the process of vesicle tethering. Vesicle fusion to the plasma membrane is known to be mediated through the attachment of proteins known as target $N$ - 
ethylmaleimide sensitive factor attachment protein receptors (t-SNARE) located on the target plasma membrane and vesicle $N$-ethylmaleimide sensitive factor attachment protein receptor (v-SNARES) located on the vesicle plasma membrane. ${ }^{142}$ However, although it is well known that attachment of both t-SNARES and v-SNARES is essential for the fusion of the vesicles to the plasma membrane, the fidelity of a specific vesicle to the desired target has been debated. ${ }^{143}$ The wide distribution of SNAREs on vesicle and target plasma membranes is not enough to account for the specific localised distribution of vesicles to their target. An example of this was demonstrated by Brennwald and colleagues ${ }^{144}$ in which they found that the yeast SNAREs Sso1p and Sso2p were widely distributed over the plasma membrane of both vesicles and target, however vesicles still arrived at specific destinations. This specificity is now thought to be attributed to the tether complexes such as the conserved oligomeric golgi (COG) and the golgi-associated retrograde protein (GARP), which have been demonstrated to form the first initial link between the vesicle and the plasma membrane aiding in the recognition of the vesicle and facilitating v-SNARE and t-SNARE binding. ${ }^{142,143,145}$

The GOG tethering complex is apart of a class of tethering factors along with GARP and the exocyst complex known as the CATCHR (complexes associated with tethering containing helical rods). Although these tethering complexes belong to the same family they share few sequence similarities with the exception of a conserved helical bundle. ${ }^{142}$ As shown in figure 3.11A the COG complex consists of 8 subunits, which are organised in two to distinct lobes that have few structural and functional similarities. ${ }^{146}$ The essential COG4 is proposed to bind directly to the v-SNARE, Syll and Vps45 through N-terminal helical coiled-coil mediating and stabilising the interaction with the vesicle. COG domains 6 and 7 also bind directly to the SNAREs via the same mechanism further aiding in stabilisation. ${ }^{142}$ The COG tethering complex has been stated to regulate the intra-golgi and endosome-to-golgi trafficking. ${ }^{143}$, 147,146,142 All four non essential subunits were among the genes that defined as sensitive to both compounds $\mathbf{2 3}$ and $\mathbf{5 4}$ (see table 3.5).

Although the GARP complex is less extensively characterised than the remanding two members of the CATCHR family, the COG and exocyst complex, it is still known to facilitate retrograde trafficking of vesicles from the late endosome to the golgi. ${ }^{148,148}$ 114 
An example of this was demonstrated by Fröhlich and colleauges, ${ }^{149}$ who were investigating the importance of retrograde trafficking from the endosome to the golgi for sphingolipid homeostasis. Upon a quantitative genome-wide synthetic lethality assay in yeast they found one of the strongest hypersensitivity was towards genes of the GARP complex. This later allowed them to propose that the GARP complex was essential for retrograde trafficking of sphingolipid from the endosome to the golgi. As shown in figure 3.11B the GARP complex consists of 4 subunits of which Vps51 has been shown to be essential in the tethering process. It has been shown that in the absence of Vsp51 the remaining GARP complex can still form however no binding to Stx6 occurs. However lack of one of the remaining subunits in the presence of Vps51 only slightly reduces binding. ${ }^{148}$ As shown in figure 3.11, Vsp52 and 53 also bind directly with the yeast SNARE stx6. With the exception of Vsp52 and Vps53, which are not in the $p d r 1 \Delta p d r 3 \Delta \mathrm{xxx} \Delta$ deletion library, deletion of the other members of the GARP complex led to sensitivity.

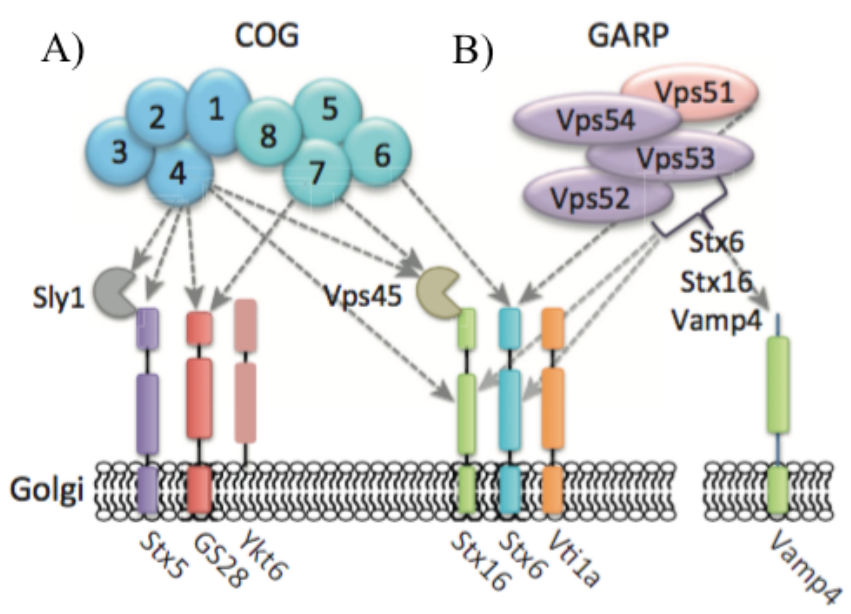

Figure 3.11: Multi subunit tethering complexes COG and GARP interacting with membrane bound SNAREs, allowing for the stabilisation of vesicles. A) Indicting the 8 subunits of COG with the interactions of COG4, COG7 and COG6 directly with the SNAREs. B) The GARP complex, Vps51 is essential in the function of the GARP complex as lack of Vps51 has been shown to inhibit GARP tethering. Figure adopted from Hong and colleagues with rights from the publisher. ${ }^{142}$

The final member of the tethering CATCHR family, the excoyst complex is an essential gene in the viability of yeast. Much like the COG and the GARP complex 
the exocyst complex aids in vesicle tethering indirectly facilitating SNARE docking. ${ }^{142,145}$ As shown in figure 3.12 the exocyst complex consists of 8 subunits, of which Sec3 and Sec70 have been shown to interact strongly with the plasma membrane via electronic interactions and Sec4 interacts with the vesicle. Establishment of these interactions facilitates the interaction of the v-SNARE and the t-SNARE. ${ }^{142,145}$ As stated above, partial inhibition of an essential gene with a low drug concentration would lead to a reduced growth in all viable strains however stains with coinciding deletions is related processes would lead to hypersensitivity. As hypersensitivity was seen in the in strains which contained deletions in either the COG or GARP complex, which are closely related to the exocyst system, this allowed for the speculation of potential inhibition of a component of the exocyst complex or a protein closely associated with the exocyst complex. Interestingly the exocyst complex has also been shown to interact both physically and functionally with the Sec61 complex. ${ }^{150,151}$ Toikkanen and colleagues ${ }^{150}$ showed that through overexpression of the Sec61 $\beta$ gene they were able to suppress the growth defects of all excocyst mutants. Therefore, by expansion of this, Sec61 mutants should cause hypersensitivity and reduced growth in yeast when the exocyst complex is been inhibited. This is exactly what is observed in the chemical genetic screens further adding weight to potential inhibition of an aspect of the exocyst system or associated proteins.

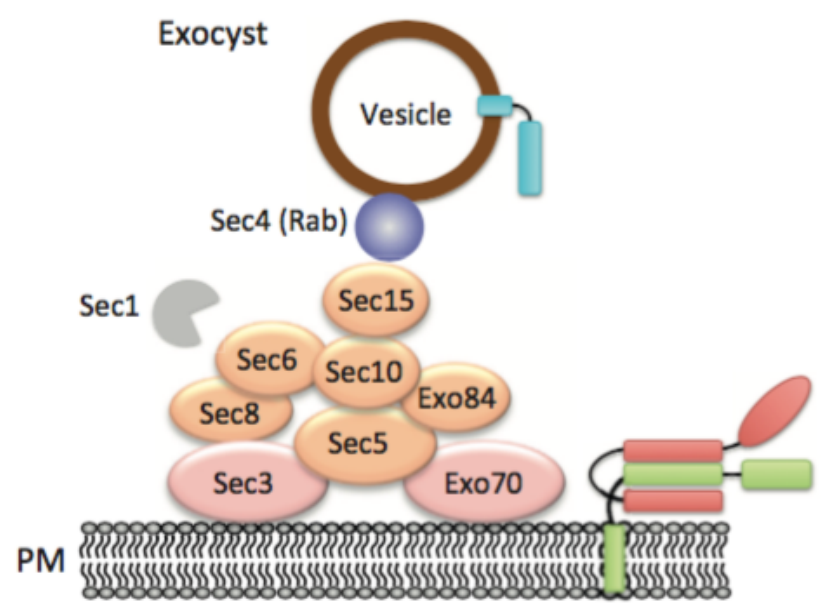

Figure 3.12: The exocyst multi subunit tethering complex. indirectly facilitating the docking of tSNAREs and v-SNAREs. Figure adopted from Hong and colleagues with rights from the publisher. ${ }^{142}$ 
The final protein complex that was identified in the chemical screens as being sensitive to compounds $\mathbf{2 3}$ and $\mathbf{5 4}$ is the ER membrane protein complex (EMC). The EMC was initially proposed to be associated with the unfolded protein response (UPR), ${ }^{152,153}$ which would explain the gene ontology enrichment in protein folding (table 3.2, figure 3.9), however, new studies suggest that the complex is more likely involved in the process of retrograde and anterograde transport ${ }^{154}$ with more recent publications proposing that the EMC complex directly aids in ER to mitochondrial vesicle tethering. ${ }^{155}$ This adds further weight to the hypothesis that compound $\mathbf{2 3}$ and 54 are involved in the inhibition of protein tethering.

Although no enrichment was found in the common resistant strains, analysis of the strains resistant to compound $\mathbf{5 4}$ showed enrichment in SNARE complex and SNAP receptor activity. SNAP is one of the four essential $\alpha$-helices that make up the SNARE complex. Although the exact interaction and involvement of 23 and $\mathbf{5 4}$ remains unknown resistance in both the SNAREs and the SNAPs reinforces the idea that the compounds are closely associated with vesicle tethering and the exocyst system.

\subsection{Affinity purification of target protein}

As the target of the synthesised 1,2-cyclopropyl carbohydrates remains unknown, attempts to isolate the target were undertaken through the use of an affinity purification resin. Although Davies ${ }^{2}$ was unsuccessful in his attempts of isolating the target protein he did report potential involvement of the compounds in transcription and translation. It was therefore assumed that, like the majority of drugs, the target of the 1,2-cyclopropyl carbohydrates was a protein.

The unsuccessful attempts at target isolation by Davies ${ }^{2}$ was found to be due the inactivity of his probe modified compounds which contained p-azidobenzyl substituents at carbons C-3 and C-4 position. This indicated a potential essential interaction with the target at these positions, therefore we hypothesised that attachment of a propargyl probe at the C-7 position might extend out of the binding pocket and allow of a copper-assisted azide-alkyne cycloaddition reaction to occur 
with an azide modified resin. In order to test this hypothesis compound $\mathbf{6 1}$ was successfully synthesised and an initial biological analysis was conducted on the $\mathbf{6 1}$ which indicated bioactivity in the low micromolar concentration similar to that of $\mathbf{5 4}$. However due to the addition of only 5 atoms onto the C-7 carbon speculation still remained whether the propargyl probe would be long enough to extend out of the binding pocket and interact with the azide modified resin.

Whole cell lysate from S. cerevisiae was treated with $\mathbf{6 1}$ followed by the addition of the azide modified agarose resin. Following the removal of the supernatant the resin was washed with a low salt solution removing any unbound proteins followed by a high salt concentration wash. Utilisation of both the low and the high salt wash had been shown to remove any non-specific bound protein. ${ }^{156}$ A final wash using LDSpage was undertaken to remove any specific but non-covalently associated protein as it was assumed that the compound was covalently binding to the target. Finally the resin was then subjected to a trypsin digest followed by mass spec analysis.

As reported (section 3.22) no significant results were obtained from either the LTQ mass spectroscopy of the MALDI mass spectroscopy analysis. After analysis of the chemical genetic screens indicated a potential mechanism of action in protein trafficking, it was assumed that the target protein may be membrane bound therefore it would not be possible to isolate the target through an affinity purification as the insoluble membrane is removed in the first stage of preparing the cell lysate.

\section{Summary}

The initial dose-responses conducted on the compounds synthesised in chapter 2 showed pleasing results with bioactivity being recorded in the mid to low micromolar concentrations range. An SAR analysis confirmed that the mechanism of inhibition was most likely occurring through a cyclopropane ring opening reaction and formation of a carbanion. Variation in bioactivity between the $\alpha$ and $\beta$ diastereoisomers suggest a that either a potential steric interactions of the binding pocket or the position of the catalytic residue or nucleophile favors $\alpha$ diastereoisomers (figure 3.8). The chemical genetic analysis preformed indicated involvement of the 
compound in protein trafficking and translocation, with further analysis of specific complexes, suggesting involvement in vesicle tethering. Consistent with this, no cytosolic target could be isolated and identified by mass spectroscopy; however, lack of target identification could also be due to other factors such as steric bulk of the target protein inhibition the interaction of the azide and alkyne. Although no target was isolated through an affinity purification process, the exocyst complex was found to be an essential complex central to the identified sensitive strains, therefore future work would revolve around the exocyst system to better understand its involvement in the mechanism of action of the synthesised 1,2-cyclopropyl carbohydrates. 


\section{Chapter 4}

\section{Conclusion}

\subsection{Future directions}

Although much work has been done throughout this thesis towards the elucidation of the mechanism of action of 1,2-cyclopropyl carbohydrates, many areas of investigation still remain. While the target 1,2-cyclopropyl carbohydrates $\mathbf{2 3}, \mathbf{5 4}$ and 61 were successfully synthesised, it would be valuable to further increase the library of 1,2-cyclopropyl carbohydrate derivatives in order to better understand the structure-activity relationship needed for bioactivity and in turn increasing the overall biological activity. Further work to identify the target through affinity purification and/or better understand the mechanism of action would also be needed as the next essential step in the development the 1,2-cyclopropyl carbohydrates derivatives towards their use as pharmaceutical compounds.

\subsubsection{Structure-activity relationship}

As previous SAR assays conducted by Davies ${ }^{2}$ identified several essential pharmacophore elements around the pyranose ring, such as benzyl groups at the C-3 and C-4 position along with a hydroxyl group at the C-6 position, the limitations of the binding pocket around the ethyoxy- and propargyloxycarbonyl substituent of $\mathbf{5 4}$ and 61 remain largely unknown. Extension of the alkyl chain would allow investigation as to whether the chain is orientated such that it protrudes out of the binding pocket and in turn potentially eluding to the depth of the binding pocket. This would be indicated by either a constant bioactivity in the mid to low micro molar concentration, or, if the alkane chain does not protrude out of the binding pocket a decrease in bioactivity will be observed with an increasing chain length. Extending the alkane chain will also increase the LogP (The logarithm of the partition coefficient between water and 1-octanol). Increasing lipophilicity of the compound might allow 
for easier access into the cell, alternatively use of a more polar substituent at this position may reduce the sensitivity of the compound to the action of efflux pumps. If extension of the alkane chain is successful and bioactivity is retained this may address previous concerns that the propargyl group on compound $\mathbf{6 1}$ was not protruding out of the binding pocket limiting its ability to interact with the derivatised matrix. Therefore addition of an alkyne group onto an extended alkane chain would overcome this issue increasing the ability for the copper-assisted azide-alkyne cycloaddition.

The use of alternative stereochemistry around the pyranose ring should also be investigated though a SAR assay. Use of galactose, mannose and allose would provide alternative stereochemistry around the pyranose ring, which may affect the bioactivity of the 1,2-cylopropyl carbohydrate derivatives. Use of these alternatives substrates will also give vital information about the 1,2-cyclopropyl carbohydrates binding site.

\subsubsection{Elucidation of the mechanism of action and target identification}

Despite great progress being made in the identification of the mechanism of action, the exact mechanism and target of the 1,2-cyclopropyl carbohydrates still remains unknown. Use of yeast library tagged with green fluorescent protein (GFP) would allow for the visualisation of any changes in protein localisation in response to the 1,2-cyclopropyl carbohydrates. As the 1,2-cyclopropyl carbohydrate derivatives have indicated to be involved in post-translational protein trafficking this would indicate where protein trafficking is been stopped. ${ }^{157}$ Alternatively attachment of a GFP to a propargyloxycarbonyl substituted 1,2-cyclopropyl carbohydrate like $\mathbf{6 1}$ and $\mathbf{6 2}$, could allow for the visualisation of where the compounds are going within the cell.

Isolation and identification of the biological target may prove to be the most important next stage in understanding the potential pharmaceutical benefit of these 1,2-cyclopropyl carbohydrates. Unsuccessful target isolation and identification in this thesis was thought to be due to either the propargyl probe on compound $\mathbf{6 1}$ not extending out of the binding pocket or that the target was a membrane bound protein. To overcome these issues future work should initially focus on a membrane affinity 
purification, which would isolate the target if it is membrane bound protein. If no target is isolated then the second attempt should focus on the derivatisation of the propargyloxycarbonyl in attempt to extend the alkane chain. This would potentially allow for the extension of the propargyl out of the binding pocket allowing it to interact with the modified matrix.

\subsection{Conclusion}

The initial aim of this Masters project was to synthesise a small library of 1,2cyclopropyl carbohydrates in order to test whether these compound were undergoing mechanism-based covalent binding through a cyclopropane ring opening reaction. This hypothesis was tested through the preparation of compounds $\mathbf{2 3}$ and the carboxyalky 1,2-cyclopropyl carbohydrate derivatives 54 and 61, which if subjected to an enzymatic nucleophilic attack at $\mathrm{C}-1$ leading to a cyclopropane ring opening would be able to stabilise the carbanion formation through the electronegative chlorines of 23 and enolate stabilisation of 54 and 61. Successful synthesis of 23, 54 and 61 was achieved in yields of $32 \%, 22 \%$ and $9 \%$ respectively over 7 steps. Chemical genetic profiling of compounds 23,54 and 61 against a $p d r 1 \Delta p d r 3 \Delta$ yeast strain resulted in bioactivity in the low macromolar concentration indicating cyclopropane ring opening and carbanion formation as the likely mechanism of inhibition.

As these compounds were found to be bioactive identification of the mechanism of action was undertaken with compound $\mathbf{2 3}$ and $\mathbf{5 4}$ through a chemical genetic analysis utilising a PDR-deficient yeast deletion strain, pdr1 $\Delta p d r 3 \Delta x x x \Delta$ library. A highthroughput assay identified a total of 132 resistant and 67 sensitive strains for compound 23 with 83 resistant and 106 sensitive strains for compound 54, which were all subjected further validation. Validated genes were subjected to a gene ontology analysis and enrichment was found in protein trafficking and localisation with notable involvement in vesicle tethering, revealed through chemical genetic interactions with the GARP, GOG, Sec63, Ssh1 and EMC complexes. Although no target protein was isolated through affinity purification the impressive specificity of chemical genetic screens strongly indicate the mechanism of action of the 1,2- 
cyclopropyl carbohydrates in protein localisation and vesicle tethering. A potential role for the exocyst complex in the mechanism of action of these compounds is proposed for future evaluation.

Although much work still needs to be done through the chemical synthesis of more 1,2-cyclopropyl carbohydrates derivatives and further biological analysis to better understand their mechanism of action, the use of 1,2-cyclopropyl carbohydrates as potential pharmaceuticals or probes of protein trafficking functions shows much promise. 


\section{References}

1. Sanhueza, C. A.; Mayato, C.; Machı'n, R. P.; Padrón, J. M.; Dorta, R. L.; Vázquez, J. T., Cytotoxic effects of C-glycosides in HOS and HeLa cell lines. Bioorg. Med. Chem. Lett. 2007, 17 (13), 3676-3681.

2. Davies, D. Mechanism-Based Design of Bioactive Cyclopropanated Sugars. Victoria University of Wellington, 2014, 2014.

3. Harvey, J. E.; Hewitt, R. J.; Moore, P. W.; Somarathne, K. K., Reactions of 1,2-cyclopropyl carbohydrates. Pure Appl. Chem. 2014, 86 (9), 1377-1399.

4. Drews, J., Drug Discovery: A Historical Perspective. Science 2000, 287 (5460), 1960-1964.

5. Balunas, M. J.; Kinghorn, A. D., Drug discovery from medicinal plants. Life Sci. 2005, 78 (5), 431-441.

6. Fleming, A., On the Antibacterial Action of Cultures of a Penicillium, with Special Reference to their Use in the Isolation of B. influenzæ. The British Journal of Experimental Pathology 1929, 10 (3), 226-236.

7. Newman, D. J.; Cragg, G. M., Natural Products As Sources of New Drugs over the 30 Years from 1981 to 2010. J. Nat. Prod. 2012, 75 (3), 311-335.

8. Kitchen, D. B.; Decornez, H.; Furr, J. R.; Bajorath, J., Docking and scoring in virtual screening for drug discovery: Methods and applications. Nature Reviews Drug Discovery 2004, 3 (11), 935-949.

9. Roberts, N.; Martin, J.; Kinchington, D.; Broadhurst, A.; Craig, J.; Duncan, I.; Galpin, S.; Handa, B.; Kay, J.; Krohn, A.; al., e., Rational design of peptide-based HIV proteinase inhibitors. Science 1990, 248 (4953), 358-361.

10. Anderson, A. C., The Process of Structure-Based Drug Design. Chem. Biol. 2003, 10 (9), 787-797.

11. Kurogi, Y.; Guner, O. F., Pharmacophore modeling and three-dimensional database searching for drug design using catalyst. Curr. Med. Chem. 2001, 8 (9), 1035-1055.

12. Acharya, C.; Coop, A.; Polli, J. E.; MacKerell, A. D., Jr., Recent Advances in Ligand-Based Drug Design: Relevance and Utility of the Conformationally Sampled Pharmacophore Approach. Curr. Comput. Aided Drug Des. 2011, 7 (1), 10-22. 
13. Amic, D.; Davidovic-Amic, D.; Beslo, D.; Rastija, V.; Lucic, B.; Trinajstic, N., SAR and QSAR of the antioxidant activity of flavonoids. Curr. Med. Chem. 2007, $14(7), 827-845$.

14. Kubinyi, H., From narcosis to hyperspace: The history of QSAR. Quant. Struct.-Act. Relat. 2002, 21 (4), 348-356.

15. Maurer, T. S.; Tabrizi-Fard, M. A.; Fung, H.-L., Impact of mechanism-based enzyme inactivation on inhibitor potency: Implications for rational drug discovery. $J$. Pharm. Sci. 2000, 89 (11), 1404-1414.

16. Walsh, C., Suicide substrates: mechanism-based enzyme inactivators. Tetrahedron 1982, 38 (7), 871-909.

17. Silverman, R. B.; Ding, C. Z.; Borrillo, J. L.; Chang, J. T., Mechanism-based enzyme inactivation via a diactivated cyclopropane intermediate. J. Am. Chem. Soc. 1993, 115 (7), 2982-2983.

18. Tysoe, C.; Withers, S. G., Fluorinated Mechanism-Based Inhibitors: Common Themes and Recent Developments. Curr. Top. Med. Chem. 2014, 14 (7), 865-874.

19. Hausheer, F. H.; Kochat, H.; Parker, A. R.; Ding, D. Y.; Yao, S. J.; Hamilton, S. E.; Petluru, P. N.; Leverett, B. D.; Bain, S. H.; Saxe, J. D., New approaches to drug discovery and development: a mechanism-based approach to pharmaceutical research and its application to BNP7787, a novel chemoprotective agent. Cancer Chemother. Pharmacol. 2003, 52, S3-S15.

20. Vavricka, C. J.; Liu, Y.; Kiyota, H.; Sriwilaijaroen, N.; Qi, J.; Tanaka, K.; Wu, Y.; Li, Q.; Li, Y.; Yan, J.; Suzuki, Y.; Gao, G. F., Influenza neuraminidase operates via a nucleophilic mechanism and can be targeted by covalent inhibitors. Nat Commun 2013, 4, 1491.

21. Eisenthal, R.; Danson, M. J.; Hough, D. W., Catalytic efficiency and kcat/KM: a useful comparator? Trends Biotechnol. 2007, 25 (6), 247-249.

22. Singh, J.; Petter, R. C.; Baillie, T. A.; Whitty, A., The resurgence of covalent drugs. Nature Reviews Drug Discovery 2011, 10 (4), 307-317.

23. Brodie, B. B.; Reid, W. D.; Cho, A. K.; Sipes, G.; Krishna, G.; Gillette, J. R., Possible Mechanism of Liver Necrosis Caused By Aromatic Organic Compounds. Proc. Natl. Acad. Sci. U. S. A. 1971, 68 (1), 160-\&.

24. Mah, R.; Thomas, J. R.; Shafer, C. M., Drug discovery considerations in the development of covalent inhibitors. Bioorg. Med. Chem. Lett. 2014, 24 (1), 33-39. 
25. Freund, A., Ueber Trimethylen. Journal für Praktische Chemie 1882, 26 (1), 367-377.

26. Hass, H. B.; McBee, E. T.; Hinds, G. E.; Gluesenkamp, E. W., Synthesis of cyclopropane. Ind. Eng. Chem. 1936, 28, 1178-1181.

27. De Meijere, A., Introduction: Cyclopropanes and related rings. Chem. Rev. 2003, 103 (4), 931-932.

28. Suckling, C. J., The Cyclopropyl Group in Studies of Enzyme Mechanism and Inhibition. Angewandte Chemie International Edition in English 1988, 27 (4), 537552.

29. de Meijere, A., Bonding Properties of Cyclopropane and Their Chemical Consequences. Angewandte Chemie International Edition in English 1979, 18 (11), 809-826.

30. Haddow, J.; Suckling, C. J.; Wood, H. C. S., Latent inhibition of dihydrofolate reductase by a spirocyclopropyl pteridine. J. Chem. Soc., Chem. Commun. 1987, (6), 478-480.

31. Martin, S. F.; Dorsey, G. O.; Gane, T.; Hillier, M. C.; Kessler, H.; Baur, M.; Matha, B.; Erickson, J. W.; Bhat, T. N.; Munshi, S.; Gulnik, S. V.; Topol, I. A., Cyclopropane-derived peptidomimetics. Design, synthesis, evaluation, and structure of novel HIV-1 protease inhibitors. J. Med. Chem. 1998, 41 (10), 1581-1597.

32. Hillier, M. C.; Davidson, J. P.; Martin, S. F., Cyclopropane-derived peptidomimetics. Design, synthesis, and evaluation of novel Ras farnesyltransferase inhibitors. J. Org. Chem. 2001, 66 (5), 1657-1671.

33. Batchelor, R.; Hoberg, J. O., Diastereoselective formation of seven-membered oxacycles by ring-expansion of cyclopropanated galactal. Tetrahedron Lett. 2003, 44 (50), 9043-9045.

34. Hewitt, R. J.; Harvey, J. E., Synthesis of Oxepines and 2-Branched Pyranosides from a d-Glucal-Derived gem-Dibromo-1,2-cyclopropanated Sugar. The Journal of Organic Chemistry 2010, 75 (3), 955-958.

35. Moore, P. W.; Schuster, J. K.; Hewitt, R. J.; Stone, M. R. L.; Teesdale-Spittle, P. H.; Harvey, J. E., Divergent synthesis of 2-C-branched pyranosides and oxepines from 1,2-gem-dibromocyclopropyl carbohydrates. Tetrahedron 2014, 70 (39), 70327043.

36. Moore, P. W. Synthesis of 2-Branched Sugars. Victoria University of Wellington, 2012, 2012. 
37. Tong, A. H. Y.; Lesage, G.; Bader, G. D.; Ding, H.; Xu, H.; Xin, X.; Young, J.; Berriz, G. F.; Brost, R. L.; Chang, M.; Chen, Y.; Cheng, X.; Chua, G.; Friesen, H.; Goldberg, D. S.; Haynes, J.; Humphries, C.; He, G.; Hussein, S.; Ke, L.; Krogan, N.; Li, Z.; Levinson, J. N.; Lu, H.; Ménard, P.; Munyana, C.; Parsons, A. B.; Ryan, O.; Tonikian, R.; Roberts, T.; Sdicu, A.-M.; Shapiro, J.; Sheikh, B.; Suter, B.; Wong, S. L.; Zhang, L. V.; Zhu, H.; Burd, C. G.; Munro, S.; Sander, C.; Rine, J.; Greenblatt, J.; Peter, M.; Bretscher, A.; Bell, G.; Roth, F. P.; Brown, G. W.; Andrews, B.; Bussey, H.; Boone, C., Global Mapping of the Yeast Genetic Interaction Network. Science 2004, 303 (5659), 808-813.

38. Ares, J.; Durán-Peña, M. J.; Hernández-Galán, R.; Collado, I., Chemical genetics strategies for identification of molecular targets. Phytochem. Rev. 2013, 12 (4), 895-914.

39. Kawatani, M.; Osada, H., Affinity-based target identification for bioactive small molecules. MedChemComm 2014, 5 (3), 277-287.

40. St.Onge, R.; Schlecht, U.; Scharfe, C.; Evangelista, M., Forward Chemical Genetics in Yeast for Discovery of Chemical Probes Targeting Metabolism. Molecules 2012, 17 (11), 13098-13115.

41. Schenone, M.; Dancik, V.; Wagner, B. K.; Clemons, P. A., Target identification and mechanism of action in chemical biology and drug discovery. Nat. Chem. Biol. 2013, 9 (4), 232-240.

42. Cho, Y. S.; Kwon, H. J., Identification and validation of bioactive small molecule target through phenotypic screening. Biorg. Med. Chem. 2012, 20 (6), $1922-$ 1928.

43. Rix, U.; Superti-Furga, G., Target profiling of small molecules by chemical proteomics. Nat. Chem. Biol. 2009, 5 (9), 616-624.

44. Harding, M. W.; Galat, A.; Uehling, D. E.; Schreiber, S. L., A receptor for the immuno-suppressant FK506 is a cis-trans peptidyl-prolyl isomerase. Nature 1989, 341 (6244), 758-760.

45. Liu, J.; Farmer Jr, J. D.; Lane, W. S.; Friedman, J.; Weissman, I.; Schreiber, S. L., Calcineurin is a common target of cyclophilin-cyclosporin A and FKBP-FK506 complexes. Cell 1991, 66 (4), 807-815.

46. Sato, S.-i.; Murata, A.; Shirakawa, T.; Uesugi, M., Biochemical Target Isolation for Novices: Affinity-Based Strategies. Chem. Biol. 2010, 17 (6), 616-623.

47. Bantscheff, M.; Lemeer, S.; Savitski, M.; Kuster, B., Quantitative mass spectrometry in proteomics: critical review update from 2007 to the present. Anal. Bioanal. Chem. 2012, 404 (4), 939-965. 
48. Huynh, M.-L.; Russell, P.; Walsh, B., Tryptic Digestion of In-Gel Proteins for Mass Spectrometry Analysis. In Two-Dimensional Electrophoresis Protocols, Tyther, R.; Sheehan, D., Eds. Humana Press: 2009; Vol. 519, pp 507-513.

49. von Rechenberg, M.; Blake, B. K.; Ho, Y.-S. J.; Zhen, Y.; Chepanoske, C. L.; Richardson, B. E.; Xu, N.; Kery, V., Ampicillin/penicillin-binding protein interactions as a model drug-target system to optimize affinity pull-down and mass spectrometric strategies for target and pathway identification. Proteomics 2005, 5 (7), 1764-1773.

50. Scherens, B.; Goffeau, A., The uses of genome-wide yeast mutant collections. Genome Biol. 2004, 5 (7), 8.

51. Parsons, A. B.; Brost, R. L.; Ding, H.; Li, Z.; Zhang, C.; Sheikh, B.; Brown, G. W.; Kane, P. M.; Hughes, T. R.; Boone, C., Integration of chemical-genetic and genetic interaction data links bioactive compounds to cellular target pathways. Nat Biotech 2004, 22 (1), 62-69.

52. Tong, A. H. Y.; Evangelista, M.; Parsons, A. B.; Xu, H.; Bader, G. D.; Pagé, N.; Robinson, M.; Raghibizadeh, S.; Hogue, C. W. V.; Bussey, H.; Andrews, B.; Tyers, M.; Boone, C., Systematic Genetic Analysis with Ordered Arrays of Yeast Deletion Mutants. Science 2001, 294 (5550), 2364-2368.

53. Batchelor, R.; Harvey, J. E.; Teesdale-Spittle, P.; Hoberg, J. O., Mechanistic studies of rearrangements during the ring expansions of cyclopropanated carbohydrates. Tetrahedron Lett. 2009, 50 (52), 7283-7285.

54. Bickelhaupt, F. M.; Hermann, H. L.; Boche, G., $\alpha$-Stabilization of Carbanions: Fluorine Is More Effective than the Heavier Halogens. Angew. Chem. Int. Ed. 2006, $45(5), 823-826$.

55. Schneider, T. F.; Kaschel, J.; Werz, D. B., A New Golden Age for DonorAcceptor Cyclopropanes. Angew. Chem. Int. Ed. 2014, 53 (22), 5504-5523.

56. Rostovtsev, V. V.; Green, L. G.; Fokin, V. V.; Sharpless, K. B., A Stepwise Huisgen Cycloaddition Process: Copper(I)-Catalyzed Regioselective "Ligation" of Azides and Terminal Alkynes. Angew. Chem. Int. Ed. 2002, 41 (14), 2596-2599.

57. Proceedings of the Chemical Society. October 1961. Proceedings of the Chemical Society 1961, (October), 357-396.

58. Simmons, H. E.; Smith, R. D., A New Synthesis of Cyclopropanes. J. Am. Chem. Soc. 1959, 81 (16), 4256-4264.

59. Moore, P. W. Synthesis of 2-C-Branched Sugars. Thesis, Victoria University of Wellington, Victoria University of Wellington, 2012. 
60. Fedoryński, M., Syntheses of gem-Dihalocyclopropanes and Their Use in Organic Synthesis. Chem. Rev. 2003, 103 (4), 1099-1132.

61. Cousins, G. S.; Hoberg, J. O., Synthesis and chemistry of cyclopropanated carbohydrates. Chem. Soc. Rev. 2000, 29 (3), 165-174.

62. Pellissier, H., Recent developments in asymmetric cyclopropanation. Tetrahedron 2008, 64 (30-31), 7041-7095.

63. Simmons, H. E.; Cairns, T. L.; Vladuchick, S. A.; Hoiness, C. M., Cyclopropanes from Unsaturated Compounds, Methylene Iodide, and Zinc-Copper Couple. In Organic Reactions, John Wiley \& Sons, Inc.: 2004.

64. Nakamura, M.; Hirai, A.; Nakamura, E., Reaction Pathways of the Simmons-Smith Reaction. J. Am. Chem. Soc. 2003, 125 (8), 2341-2350.

65. Poulter, C. D.; Friedrich, E. C.; Winstein, S., Stereochemistry of the methylene iodide-zinc-copper couple methylenation of cyclic allylic alcohols. J. Am. Chem. Soc. 1969, 91 (24), 6892-6894.

66. von E. Doering, W.; Hoffmann, A. K., The Addition of Dichlorocarbene to Olefins. J. Am. Chem. Soc. 1954, 76 (23), 6162-6165.

67. Mąkosza, M.; Wawrzyniewicz, M., Reactions of organic anions. XXIV. Catalytic method for preparation of dichlorocyclopropane derivatives in aqueous medium. Tetrahedron Lett. 1969, 10 (53), 4659-4662.

68. Ramana, C. V.; Murali, R.; Nagarajan, M., Synthesis and Reactions of 1,2Cyclopropanated Sugars. The Journal of Organic Chemistry 1997, 62 (22), 76947703.

69. Doyle, M. P., CATALYTIC METHODS FOR METAL CARBENE TRANSFORMATIONS. Chem. Rev. 1986, 86 (5), 919-939.

70. Yates, P., The Copper-catalyzed Decomposition of Diazoketones1. J. Am. Chem. Soc. 1952, 74 (21), 5376-5381.

71. Salomon, R. G.; Kochi, J. K., Copper(I) catalysis in cyclopropanations with diazo compounds. Role of olefin coordination. J. Am. Chem. Soc. 1973, 95 (10), 3300-3310.

72. Paulissen, R.; Hubert, A. J.; Teyssie, P., Transition metal catalysed cyclopropanation of olefin. Tetrahedron Lett. 1972, 13 (15), 1465-1466. 
73. Paulissen, R.; Reimlinger, H.; Hayez, E.; Hubert, A. J.; Teyssié, P., Transition metal catalysed reactions of diazocompounds - II insertion in the hydroxylic bond. Tetrahedron Lett. 1973, 14 (24), 2233-2236.

74. Doyle, M. P., ELECTROPHILIC METAL CARBENES AS REACTION INTERMEDIATES IN CATALYTIC REACTIONS. Acc. Chem. Res. 1986, 19 (11), 348-356.

75. Pirrung, M. C.; Morehead, A. T., Saturation Kinetics in Dirhodium(II) Carboxylate-Catalyzed Decompositions of Diazo Compounds. J. Am. Chem. Soc. 1996, 118 (34), 8162-8163.

76. Hoberg, J. O.; Claffey, D. J., Cyclopropanation of unsaturated sugars with ethyl Diazoacetate. Tetrahedron Lett. 1996, 37 (15), 2533-2536.

77. Hoberg, J. O.; Bozell, J. J., Cyclopropanation and ring-expansion of unsaturated sugars. Tetrahedron Lett. 1995, 36 (38), 6831-6834.

78. Fischer, E.; Zach, K., New synthesis of bases of the sugar groups. Berichte Der Deutschen Chemischen Gesellschaft 1911, 44, 132-135.

79. Kozikowski, A. P.; Lee, J., A synthetic approach to the cis-fused marine pyranopyrans, (3E)- and (3Z)-dactomelyne. X-ray structure of a rare organomercurial. The Journal of Organic Chemistry 1990, 55 (3), 863-870.

80. Banwell, M. G.; Corbett, M.; Gulbis, J.; Mackay, M. F.; Reum, M. E., Generation and solution-phase behaviour of some 2-halogeno-1,3-ring-fused cyclopropenes. J. Chem. Soc., Perkin Trans. 1 1993, (8), 945-963.

81. Ocampo, R.; Dolbier Jr, W. R., The Reformatsky reaction in organic synthesis. Recent advances. Tetrahedron 2004, 60 (42), 9325-9374.

82. Czernecki, S.; Vijayakumaran, K.; Ville, G., Convenient synthesis of hex-1enopyran-3-uloses: selective oxidation of allylic alcohols using pyridinium dichromate. The Journal of Organic Chemistry 1986, 51 (26), 5472-5475.

83. Esswein, A.; Rembold, H.; Schmidt, R. R., O-Alkylation at the anomeric centre for the stereoselective synthesis of Kdo- $\alpha$-glycosides. Carbohydr. Res. 1990, 200, 287-305.

84. Esswein, A.; Rembold, H.; Schmidt, R. R., O-Alkylation at the anomeric centre for the stereoselective synthesis of Kdo-a-glycosides. Carbohydr. Res. 1990, $200(0), 287-305$. 
85. Brimacombe, J. S.; Evans, M. E.; Forbes, E. J.; Foster, A. B.; Webber, J. M., The addition of dichloromethylene to unsaturated sugars. Carbohydr. Res. 1967, 4 (3), 239-243.

86. Duchaussoy, P.; Di Cesare, P.; Gross, B., Synthesis of Sugars Containing the Dihalocyclopropane Moiety; A New Access to the Heptose Series. Synthesis 1979, 1979 (03), 198-200.

87. Hanessian, S.; Lavallee, P., The Preparation and Synthetic Utility of tertButyldiphenylsilyl Ethers. Can. J. Chem. 1975, 53 (19), 2975-2977.

88. Saidhareddy, P.; Ajay, S.; Shaw, A. K., 'Chiron' approach to the total synthesis of macrolide (+)-Aspicilin. RSC Advances 2014, 4 (9), 4253-4259.

89. Sabitha, G.; Reddy, S. S. S.; Yadav, J. S., Total synthesis of cryptopyranmoscatone B1 from 3,4,6-tri-O-acetyl-d-glucal. Tetrahedron Lett. 2010, 51 (48), 6259-6261.

90. Danishefsky, S. J.; Gervay, J.; Peterson, J. M.; McDonald, F. E.; Koseki, K.; Griffith, D. A.; Oriyama, T.; Marsden, S. P., Application of Glycals to the Synthesis of Oligosaccharides: Convergent Total Syntheses of the Lewis X Trisaccharide Sialyl Lewis X Antigenic Determinant and Higher Congeners. J. Am. Chem. Soc. 1995, 117 (7), 1940-1953.

91. Blackburne, I.; Fredericks, P.; Guthrie, R., Studies on unsaturated sugars with particular reference to the synthesis of 6-Deoxy-6-fluoro derivatives. Aust. J. Chem. 1976, 29 (2), 381-391.

92. Lellouche, J.-P.; Koeller, S., The Particular Sensitivity of Silyl Ethers of dGlucal toward Two Vilsmeier-Haack Reagents POCl3·DMF and (CF3SO2)2O-DMF. Their Unique and Selective Conversion to the Corresponding C(6)-O-Formates. The Journal of Organic Chemistry 2001, 66 (3), 693-696.

93. Patnaik, S.; Kalam, S.; Vanga, M., R, Design, Synthesis and Evaluation of New RGD-Peptidomimetics as Possible Antithrombotics. International Journal of Pharmaceutical Sciences and Nanotechnology 2008, 1 (3), 287-296.

94. Fischer, E.; Speier, A., Darstellung der Ester. Berichte der deutschen chemischen Gesellschaft 1895, 28 (3), 3252-3258.

95. Viirre, R. D.; Hudson, R. H. E., A Convenient and Scalable Synthesis of Ethyl $\mathrm{N}-[(2-B o c-a m i n o) e t h y l] g l y c i n a t e$ and Its Hydrochloride. Key Intermediates for Peptide Nucleic Acid Synthesis. The Journal of Organic Chemistry 2003, 68 (4), 1630-1632. 
96. Curtius, T., Ueber die Einwirkung von salpetriger Säure auf salzsauren Glycocolläther. Berichte der deutschen chemischen Gesellschaft 1883, 16 (2), 22302231.

97. (a) Maas, G., New Syntheses of Diazo Compounds. Angew. Chem. Int. Ed. 2009, 48 (44), 8186-8195; (b) Holton, T. L.; Schechter, H., Advantageous Syntheses of Diazo Compounds by Oxidation of Hydrazones with Lead Tetraacetate in Basic Environments. The Journal of Organic Chemistry 1995, 60 (15), 4725-4729.

98. Clark, J. D.; Heise, J. D.; Shah, A. S.; Peterson, J. C.; Chou, S. K.; Levine, J.; Karakas, A. M.; Ma, Y.; Ng, K.-Y.; Patelis, L.; Springer, J. R.; Stano, D. R.; Wettach, R. H.; Dutra, G. A., Process Research, Development, and Pilot-Plant Preparation of Clofencet, a Novel Wheat Hybridizing Agent: Lewis Acid-Catalyzed Reaction of Ethyl Diazoacetate with 4-Chlorophenyl Hydrazonoacetaldehyde. Organic Process Research \& Development 2004, 8 (2), 176-185.

99. Fulton, J. R.; Aggarwal, V. K.; de Vicente, J., The Use of Tosylhydrazone Salts as a Safe Alternative for Handling Diazo Compounds and Their Applications in Organic Synthesis. Eur. J. Org. Chem. 2005, 2005 (8), 1479-1492.

100. Searle, N. E., Ethyl Diazoacetate. Organic Syntheses 1956, 36, 25.

101. Ranocchiari, M.; Mezzetti, A., Ru/PNNP-Catalyzed Asymmetric Imine Aziridination by Diazo Ester Activation. Organometallics 2009, 28 (13), 3611-3613.

102. Adams, J.; Spero, D. M., Rhodium (II) catalyzed reactions of diazo-carbonyl compounds. Tetrahedron 1991, 47 (10-11), 1765-1808.

103. Timmers, C. M.; Leeuwenburgh, M. A.; Verheijen, J. C.; van der Marel, G. A.; van Boom, J. H., Rhodium(II) catalyzed asymmetric cyclopropanation of glycals with ethyl diazoacetate. Tetrahedron: Asymmetry 1996, 7 (1), 49-52.

104. Risseeuw, M. D. P.; van der Marel, G. A.; Overkleeft, H. S.; Overhand, M., Pyranocyclopropanyl sugar amino acids, a new class of constrained (di)peptide isosteres. Tetrahedron: Asymmetry 2009, 20 (6-8), 945-951.

105. Risseeuw, M. D. P.; van den Berg, R. J. B. H. N.; Donker-Koopman, W. E.; van der Marel, G. A.; Aerts, J. M. F. G.; Overhand, M.; Overkleeft, H. S., Synthesis and evaluation of d-gluco-pyranocyclopropyl amines as potential glucosidase inhibitors. Bioorg. Med. Chem. Lett. 2009, 19 (23), 6600-6603.

106. Haasnoot, C. A. G.; de Leeuw, F. A. A. M.; Altona, C., The relationship between proton-proton NMR coupling constants and substituent electronegativities-I : An empirical generalization of the karplus equation. Tetrahedron 1980, 36 (19), 2783-2792. 
107. (a) Balacco, G., A Desktop Calculator for the Karplus Equation. J. Chem. Inf. Comput. Sci. 1996, 36 (4), 885-887; (b) Coxon, B., DEVELOPMENTS IN THE KARPLUS EQUATION AS THEY RELATE TO THE NMR COUPLING CONSTANTS OF CARBOHYDRATES. Adv. Carbohydr. Chem. Biochem. 2009, 62, $17-82$

108. Ramapanicker, R.; Gupta, R.; Megha, R.; Chandrasekaran, S., Applications of Propargyl Esters of Amino Acids in Solution-Phase Peptide Synthesis. International Journal of Peptides 2011, 2011, 10.

109. Toma, T.; Shimokawa, J.; Fukuyama, T., N,N'-Ditosylhydrazine: A Convenient Reagent for Facile Synthesis of Diazoacetates†. Org. Lett. 2007, 9 (16), 3195-3197.

110. Katritzky, A. R.; Meth-Cohn, O.; Roberts, S. M.; Rees, C. W., Comprehensive Organic Functional Group Transformations. Elsevier Science: 1995.

111. Kirmse, W., CHAPTER 9 - Addition to Alkynes. In Carbene Chemistry (Second Edition), Kirmse, W., Ed. Academic Press: 1971; pp 363-380.

112. Padwa, A.; Weingarten, M. D., Rhodium(II)-Catalyzed Carbocyclization Reaction of $\alpha$-Diazo Carbonyls with Tethered Unsaturation. The Journal of Organic Chemistry 2000, 65 (12), 3722-3732.

113. Gottlieb, H. E.; Kotlyar, V.; Nudelman, A., NMR Chemical Shifts of Common Laboratory Solvents as Trace Impurities. The Journal of Organic Chemistry 1997, 62 (21), 7512-7515.

114. de Pouilly, P.; Chénedé, A.; Mallet, J.-M.; Sinaÿ, P., Reductive elimination of glycosyl phenyl sulfones by SmI2-HMPA: A convenient synthesis of substituted pyranoid glycals. Tetrahedron Lett. 1992, 33 (52), 8065-8068.

115. Legzdins, P.; Mitchell, R. W.; Rempel, G. L.; Ruddick, J. D.; Wilkinson, G., The protonation of ruthenium- and rhodium-bridged carboxylates and their use as homogeneous hydrogenation catalysts for unsaturated substances. Journal of the Chemical Society A: Inorganic, Physical, Theoretical 1970, (0), 3322-3326.

116. Goffeau, A.; Barrell, B. G.; Bussey, H.; Davis, R. W.; Dujon, B.; Feldmann, H.; Galibert, F.; Hoheisel, J. D.; Jacq, C.; Johnston, M.; Louis, E. J.; Mewes, H. W.; Murakami, Y.; Philippsen, P.; Tettelin, H.; Oliver, S. G., Life with 6000 Genes. Science 1996, 274 (5287), 546-567.

117. Human Genome Sequencing, C., Finishing the euchromatic sequence of the human genome. Nature 2004, 431 (7011), 931-945.

118. Dujon, B., The yeast genome project: what did we learn? Trends Genet. 12 (7), 263-270. 
119. Martin, S. G., Yeasts as models in cell biology. FEMS Microbiol. Rev. 2014, $38(2), 143-143$.

120. Lingner, J.; Hughes, T. R.; Shevchenko, A.; Mann, M.; Lundblad, V.; Cech, T. R., Reverse Transcriptase Motifs in the Catalytic Subunit of Telomerase. Science 1997, 276 (5312), 561-567.

121. Reichenbach, P.; Höss, M.; Azzalin, C. M.; Nabholz, M.; Bucher, P.; Lingner, J., A Human Homolog of Yeast Est1 Associates with Telomerase and Uncaps Chromosome Ends When Overexpressed. Curr. Biol. 2003, 13 (7), 568-574.

122. Sealey, D.; Kostic, A.; LeBel, C.; Pryde, F.; Harrington, L., The TPRcontaining domain within Est1 homologs exhibits species-specific roles in telomerase interaction and telomere length homeostasis. BMC Mol. Biol. 2011, 12 (1), 45.

123. Andrade, M. A.; Sander, C.; Valencia, A., Updated catalogue of homologues to human disease-related proteins in the yeast genome1. FEBS Lett. 1998, 426 (1), 716.

124. Jungwirth, H.; Kuchler, K., Yeast ABC transporters - A tale of sex, stress, drugs and aging. FEBS Lett. 2006, 580 (4), 1131-1138.

125. Coorey, N. V. C.; Matthews, J. H.; Bellows, D. S.; Atkinson, P. H., Pleiotropic drug-resistance attenuated genomic library improves elucidation of drug mechanisms. Molecular BioSystems 2015, 11 (11), 3129-3136.

126. Golin, J.; Ambudkar, S. V.; Gottesman, M. M.; Habib, A. D.; Sczepanski, J.; Ziccardi, W.; May, L., Studies with novel Pdr5p substrates demonstrate a strong size dependence for xenobiotic efflux. J. Biol. Chem. 2003, 278 (8), 5963-5969.

127. Mitterbauer, R.; Weindorfer, H.; Safaie, N.; Krska, R.; Lemmens, M.; Ruckenbauer, P.; Kuchler, K.; Adam, G., A sensitive and inexpensive yeast bioassay for the mycotoxin zearalenone and other compounds with estrogenic activity. Appl. Environ. Microbiol. 2003, 69 (2), 805-811.

128. Sherman, F., Getting started with yeast. In Methods Enzymol., Christine, G.; Gerald, R. F., Eds. Academic Press: 2002; Vol. Volume 350, pp 3-41.

129. Wagih, O.; Parts, L., gitter: A Robust and Accurate Method for Quantification of Colony Sizes From Plate Images. G3: Genes|Genomes|Genetics 2014, 4 (3), $547-$ 552.

130. Dittmar, J.; Reid, R.; Rothstein, R., ScreenMill: A freely available software suite for growth measurement, analysis and visualization of high-throughput screen data. BMC Bioinformatics 2010, 11 (1), 353. 
131. Cherry, J. M.; Hong, E. L.; Amundsen, C.; Balakrishnan, R.; Binkley, G.; Chan, E. T.; Christie, K. R.; Costanzo, M. C.; Dwight, S. S.; Engel, S. R.; Fisk, D. G.; Hirschman, J. E.; Hitz, B. C.; Karra, K.; Krieger, C. J.; Miyasato, S. R.; Nash, R. S.; Park, J.; Skrzypek, M. S.; Simison, M.; Weng, S.; Wong, E. D., Saccharomyces Genome Database: the genomics resource of budding yeast. Nucleic Acids Res. 2012, 40 (D1), D700-D705.

132. Engel, S. R.; Dietrich, F. S.; Fisk, D. G.; Binkley, G.; Balakrishnan, R.; Costanzo, M. C.; Dwight, S. S.; Hitz, B. C.; Karra, K.; Nash, R. S.; Weng, S.; Wong, E. D.; Lloyd, P.; Skrzypek, M. S.; Miyasato, S. R.; Simison, M.; Cherry, J. M., The Reference Genome Sequence of Saccharomyces cerevisiae: Then and Now. G3: Genes|Genomes|Genetics 2014, 4 (3), 389-398.

133. Reimand, J.; Kull, M.; Peterson, H.; Hansen, J.; Vilo, J., g:Profiler-a webbased toolset for functional profiling of gene lists from large-scale experiments. Nucleic Acids Res. 2007, 35 (Web Server issue), W193-W200.

134. Reimand, J.; Arak, T.; Vilo, J., g:Profiler-a web server for functional interpretation of gene lists (2011 update). Nucleic Acids Res. 2011.

135. Todoroki, Y.; Nakano, S.-i.; Hirai, N.; Ohigashi, H., Ring conformational requirement for biological activity of abscisic acid probed by the cyclopropane analogues. Tetrahedron 1996, 52 (24), 8081-8098.

136. Liu, J. Q.; Kurihara, T.; Miyagi, M.; Esaki, N.; Soda, K., REACTIONMECHANISM OF L-2-HALOACID DEHALOGENASE OF PSEUDOMONAS SP. YL - IDENTIFICATION OF ASP(10) AS THE ACTIVE-SITE NUCLEOPHILE BY O-18 INCORPORATION EXPERIMENTS. J. Biol. Chem. 1995, 270 (31), 1830918312.

137. Maere, S.; Heymans, K.; Kuiper, M., BiNGO: a Cytoscape plugin to assess overrepresentation of Gene Ontology categories in Biological Networks. Bioinformatics 2005, 21 (16), 3448-3449.

138. Zimmermann, R.; Eyrisch, S.; Ahmad, M.; Helms, V., Protein translocation across the ER membrane. Biochim. Biophys. Acta 2011, 1808 (3), 912-924.

139. Park, E.; Rapoport, T. A., Mechanisms of Sec61/SecY-Mediated Protein Translocation Across Membranes. Annual Review of Biophysics 2012, 41 (1), 21-40.

140. Harty, C.; Römisch, K., Analysis of Sec61p and Ssh1p interactions in the ER membrane using the split-ubiquitin system. BMC Cell Biol. 2013, 14, 14-14.

141. Junne, T.; Wong, J.; Studer, C.; Aust, T.; Bauer, B. W.; Beibel, M.; Bhullar, B.; Bruccoleri, R.; Eichenberger, J.; Estoppey, D.; Hartmann, N.; Knapp, B.; Krastel, P.; Melin, N.; Oakeley, E. J.; Oberer, L.; Riedl, R.; Roma, G.; Schuierer, S.; Petersen, F.; Tallarico, J. A.; Rapoport, T. A.; Spiess, M.; Hoepfner, D., Decatransin, a new 
natural product inhibiting protein translocation at the Sec61/SecYEG translocon. $J$. Cell Sci. 2015, 128 (6), 1217-1229.

142. Hong, W.; Lev, S., Tethering the assembly of SNARE complexes. Trends Cell Biol. 2014, 24 (1), 35-43.

143. Whyte, J. R. C.; Munro, S., Vesicle tethering complexes in membrane traffic. J. Cell Sci. 2002, 115 (13), 2627-2637.

144. Brennwald, P.; Kearns, B.; Champion, K.; Keränen, S.; Bankaitis, V.; Novick, P., Sec9 is a SNAP-25-like component of a yeast SNARE complex that may be the effector of Sec4 function in exocytosis. Cell 1994, 79 (2), 245-258.

145. Heider, M. R.; Munson, M., Exorcising the Exocyst Complex. Traffic (Copenhagen, Denmark) 2012, 13 (7), 898-907.

146. Loh, E.; Hong, W., The Binary Interacting Network of the Conserved Oligomeric Golgi Tethering Complex. J. Biol. Chem. 2004, 279 (23), 24640-24648.

147. Whyte, J. R. C.; Munro, S., The Sec34/35 Golgi Transport Complex Is Related to the Exocyst, Defining a Family of Complexes Involved in Multiple Steps of Membrane Traffic. Dev. Cell 2001, 1 (4), 527-537.

148. Conibear, E.; Cleck, J. N.; Stevens, T. H., Vps51p Mediates the Association of the GARP (Vps52/53/54) Complex with the Late Golgi t-SNARE Tlg1p. Mol. Biol. Cell 2003, 14 (4), 1610-1623.

149. Fröhlich, F.; Petit, C.; Kory, N.; Christiano, R.; Hannibal-Bach, H.-K.; Graham, M.; Liu, X.; Ejsing, C. S.; Farese, R. V.; Walther, T. C., The GARP complex is required for cellular sphingolipid homeostasis. eLife 2015.

150. Toikkanen, J. H.; Miller, K. J.; Söderlund, H.; Jäntti, J.; Keränen, S., The $\beta$ Subunit of the Sec61p Endoplasmic Reticulum Translocon Interacts with the Exocyst Complex in Saccharomyces cerevisiae. J. Biol. Chem. 2003, 278 (23), 20946-20953.

151. Lipschutz, J. H.; Lingappa, V. R.; Mostov, K. E., The Exocyst Affects Protein Synthesis by Acting on the Translocation Machinery of the Endoplasmic Reticulum. J. Biol. Chem. 2003, 278 (23), 20954-20960.

152. Jonikas, M. C.; Collins, S. R.; Denic, V.; Oh, E.; Quan, E. M.; Schmid, V.; Weibezahn, J.; Schwappach, B.; Walter, P.; Weissman, J. S.; Schuldiner, M., Comprehensive characterization of genes required for protein folding in the endoplasmic reticulum. Science (New York, N.Y.) 2009, 323 (5922), 1693-1697.

153. Christianson, J. C.; Olzmann, J. A.; Shaler, T. A.; Sowa, M. E.; Bennett, E. J.; Richter, C. M.; Tyler, R. E.; Greenblatt, E. J.; Harper, J. W.; Kopito, R. R., Defining 
human ERAD networks through an integrative mapping strategy. Nat. Cell Biol. 2011, 14 (1), 93-105.

154. Bircham, P. W.; Maass, D. R.; Roberts, C. A.; Kiew, P. Y.; Low, Y. S.; Yegambaram, M.; Matthews, J.; Jack, C. A.; Atkinson, P. H., Secretory pathway genes assessed by high-throughput microscopy and synthetic genetic array analysis. Molecular BioSystems 2011, 7 (9), 2589-2598.

155. Lahiri, S.; Chao, J. T.; Tavassoli, S.; Wong, A. K. O.; Choudhary, V.; Young, B. P.; Loewen, C. J. R.; Prinz, W. A., A Conserved Endoplasmic Reticulum Membrane Protein Complex (EMC) Facilitates Phospholipid Transfer from the ER to Mitochondria. PLoS Biol. 2014, 12 (10), e1001969.

156. Matthews, J. H. The Molecular Pharmacology of Patamine A. Victoria University of Wellington, 2010.

157. Huh, W.-K.; Falvo, J. V.; Gerke, L. C.; Carroll, A. S.; Howson, R. W.; Weissman, J. S.; O'Shea, E. K., Global analysis of protein localization in budding yeast. Nature 2003, 425 (6959), 686-691. 


\section{Appendix}

\section{Spectra}

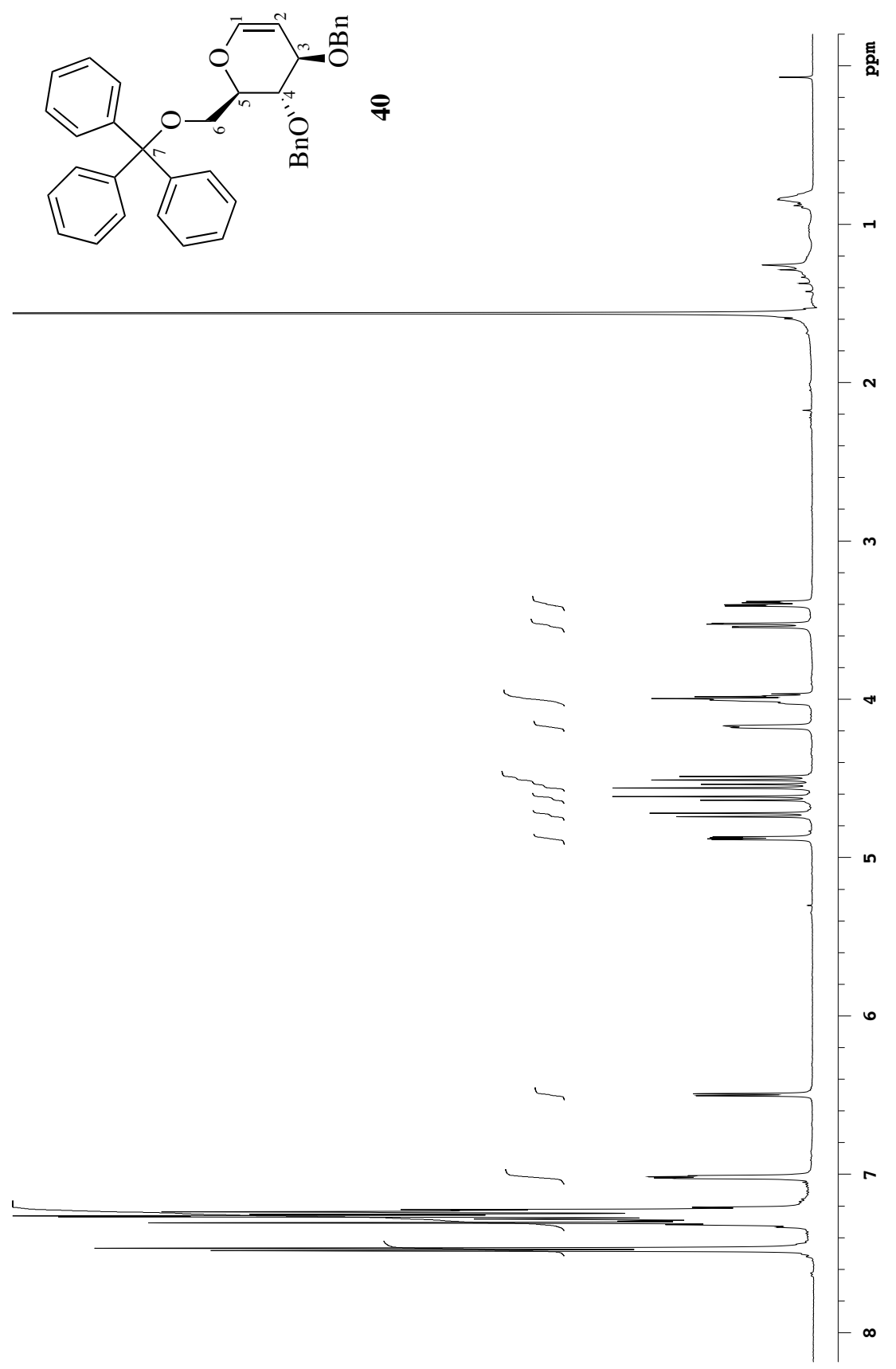

${ }^{1} \mathrm{H}$ NMR of the cyclopropane substrate $40\left(500 \mathrm{MHz}, \mathrm{CDCl}_{3}\right)$ 


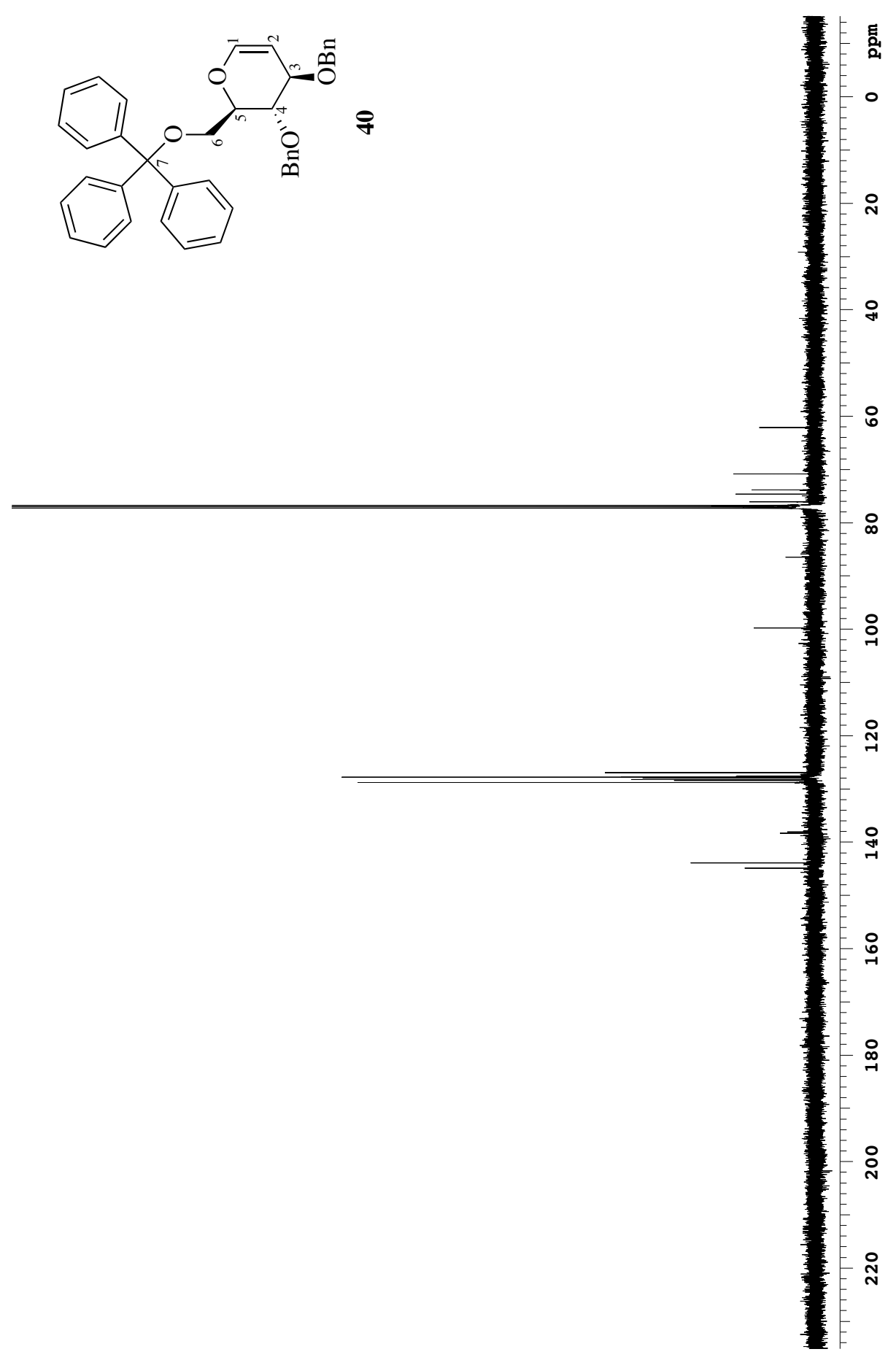

${ }^{13} \mathrm{C}$ NMR of the cyclopropane substrate $40\left(500 \mathrm{MHz}, \mathrm{CDCl}_{3}\right)$ 


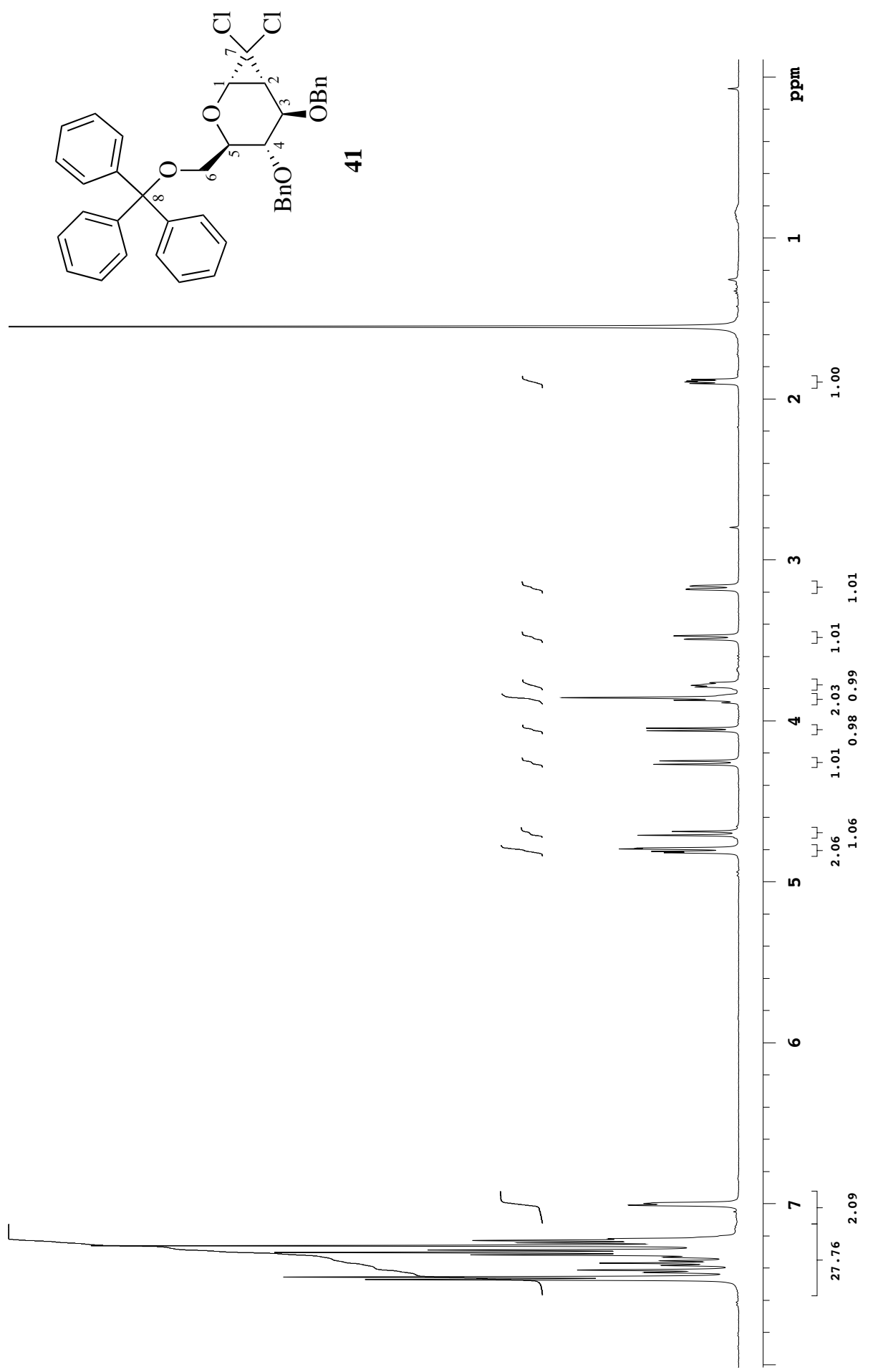

${ }^{1} \mathrm{H}$ NMR of the C-6 protected 1,2-cyclopropyl carbohydrate 41 (500 MHz, $\mathrm{CDCl}_{3}$ ) 
${ }^{13} \mathrm{C}$ NMR of the C-6 protected 1,2-cyclopropyl carbohydrate 41 (500 MHz, $\mathrm{CDCl}_{3}$ ) 


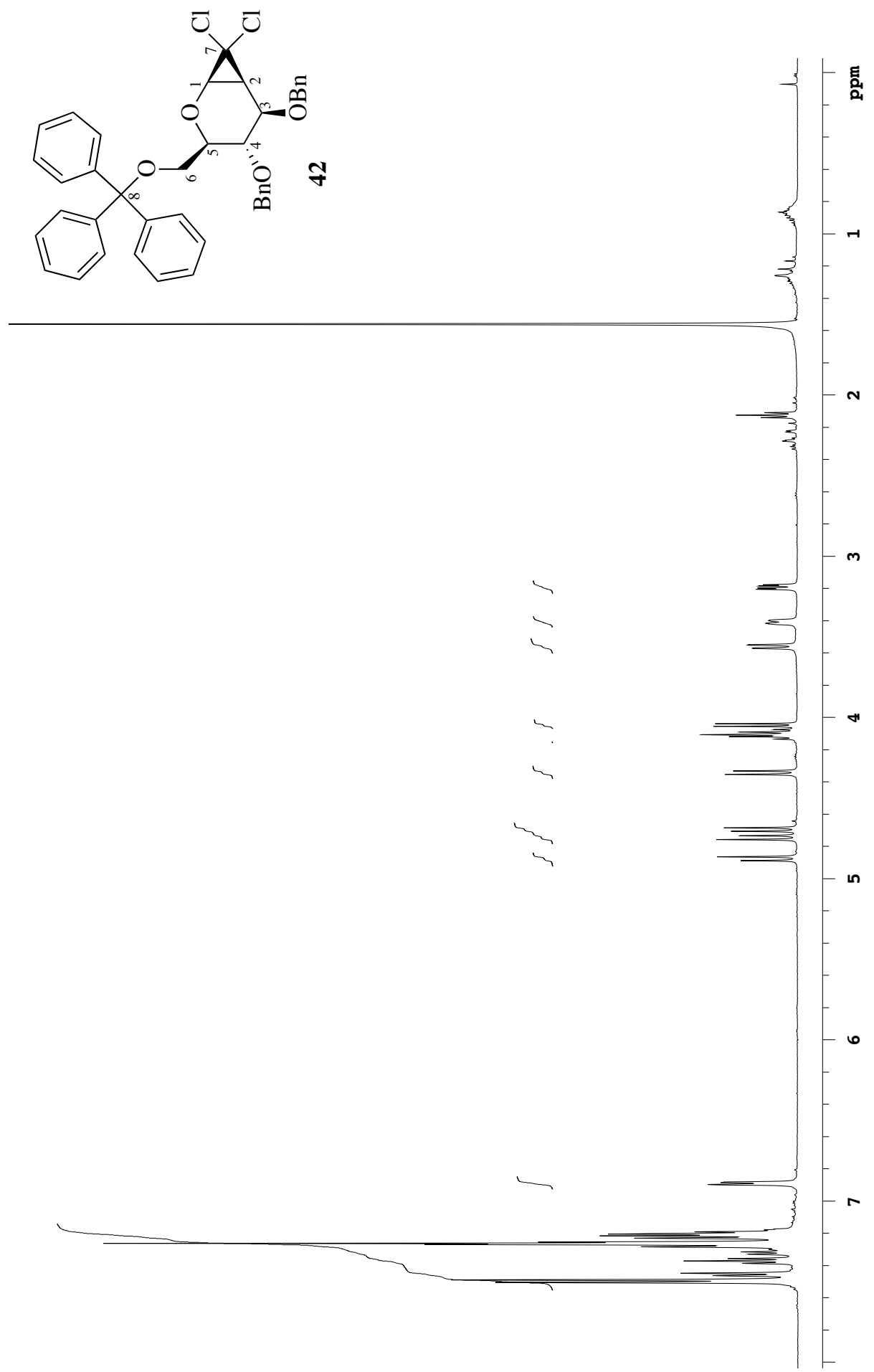

${ }^{1} \mathrm{H}$ NMR of the C-6 protected 1,2-cyclopropyl carbohydrate $41\left(500 \mathrm{MHz}, \mathrm{CDCl}_{3}\right)$ 

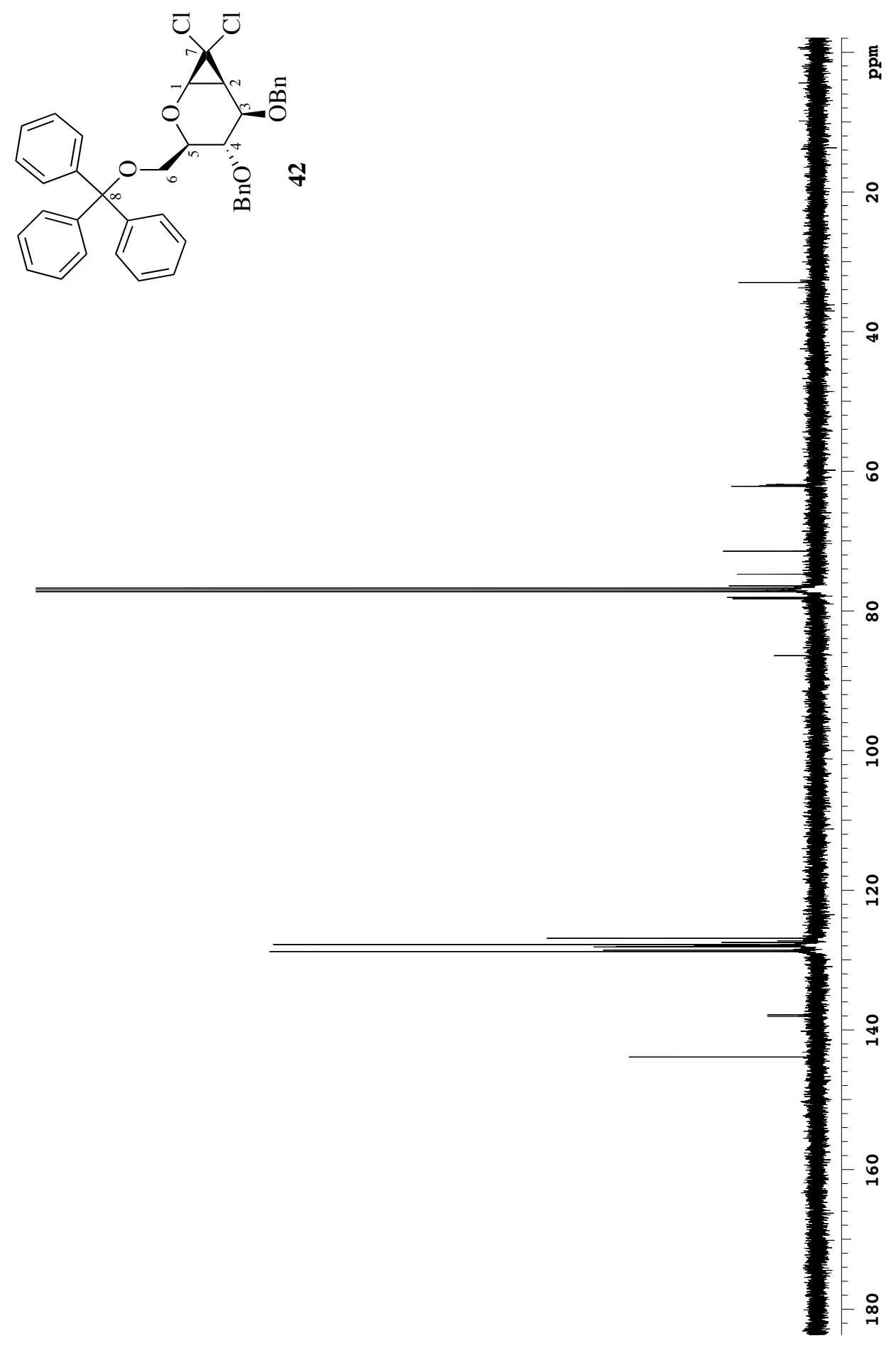

${ }^{13} \mathrm{C}$ NMR of the C-6 protected 1,2-cyclopropyl carbohydrate $42\left(500 \mathrm{MHz}, \mathrm{CDCl}_{3}\right)$ 

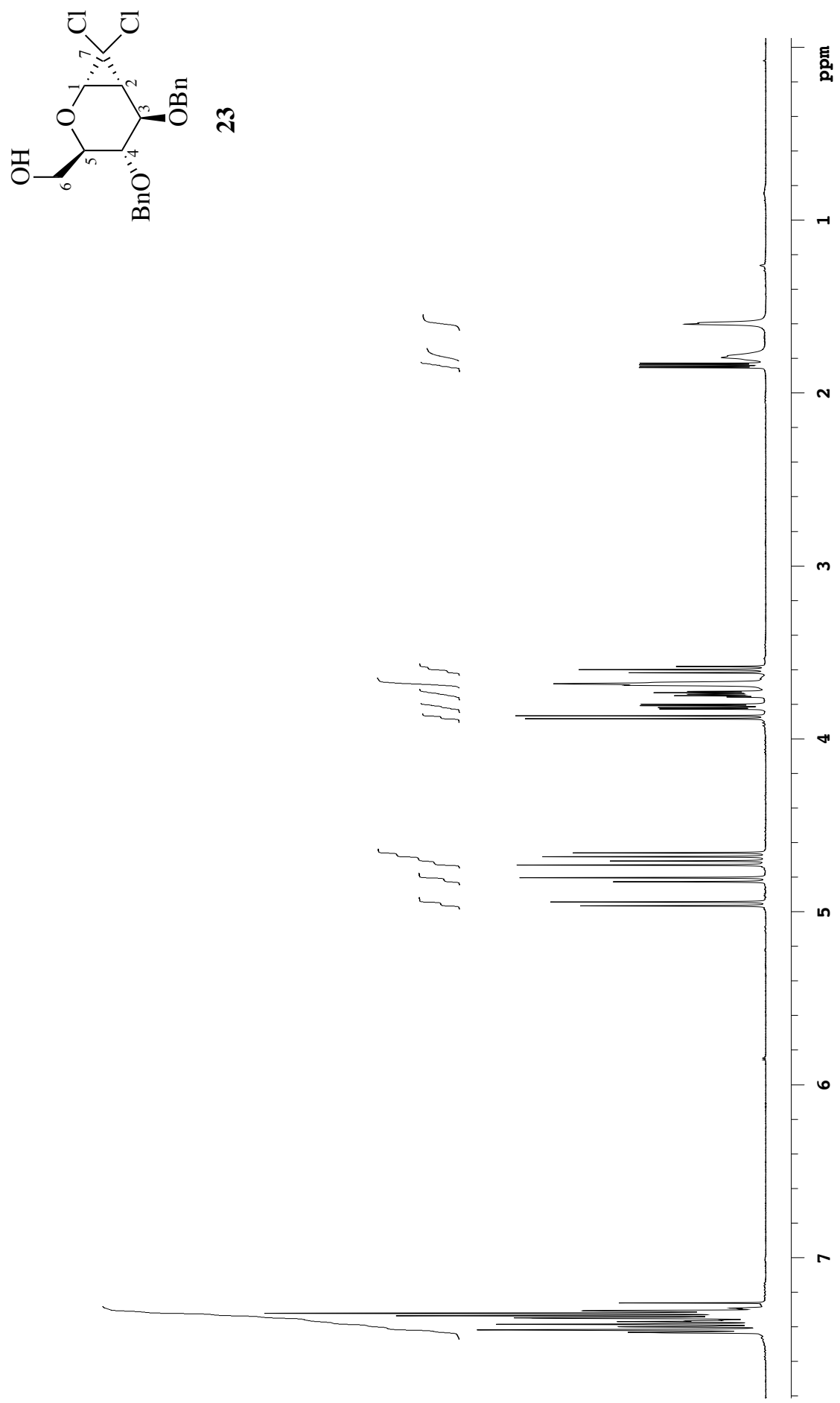

${ }^{1} \mathrm{H}$ NMR of the 1,2-cyclopropyl carbohydrate $23\left(500 \mathrm{MHz}, \mathrm{CDCl}_{3}\right)$ 

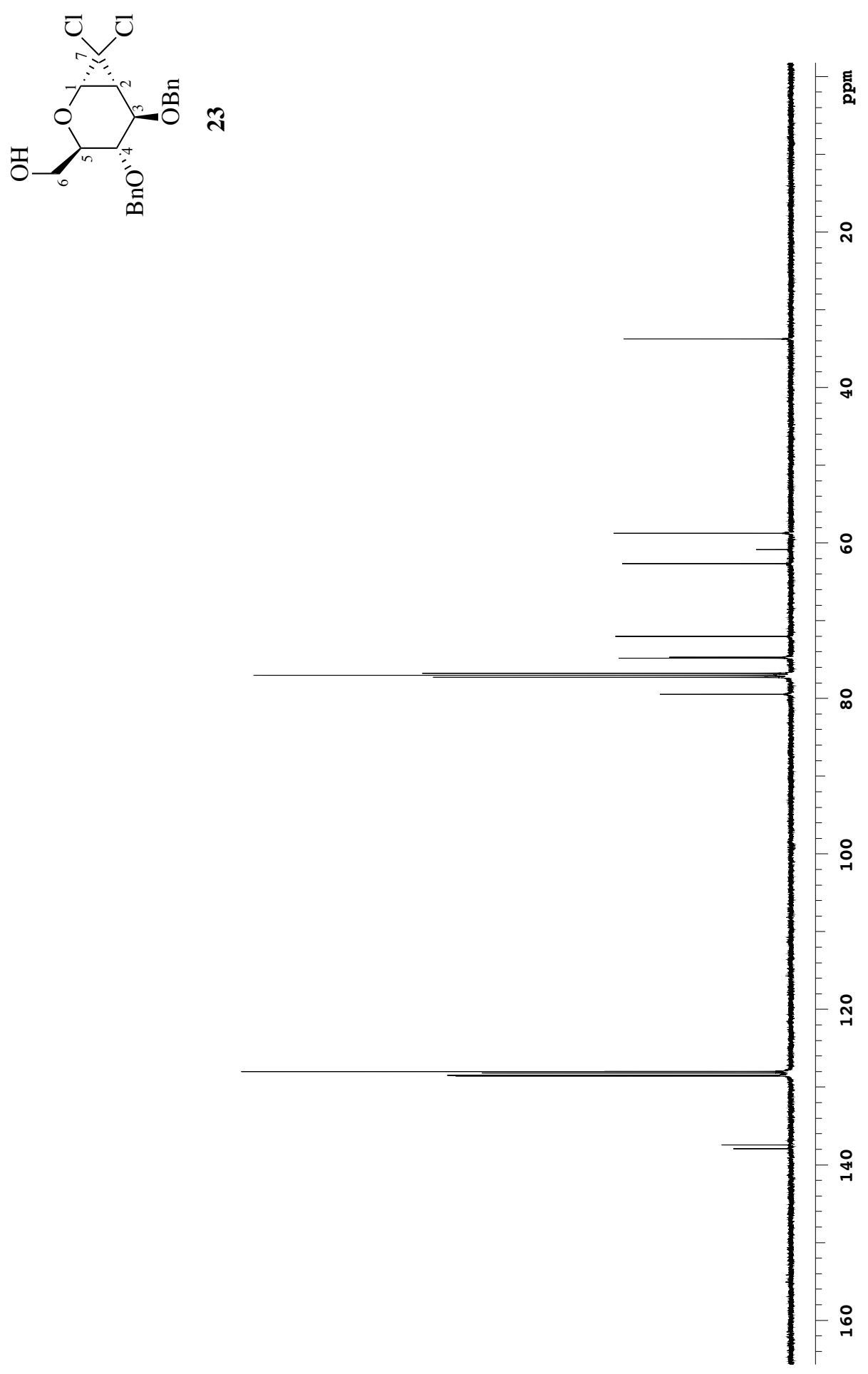

${ }^{13} \mathrm{C}$ NMR of the 1,2-cyclopropyl carbohydrate $23\left(500 \mathrm{MHz}, \mathrm{CDCl}_{3}\right)$ 

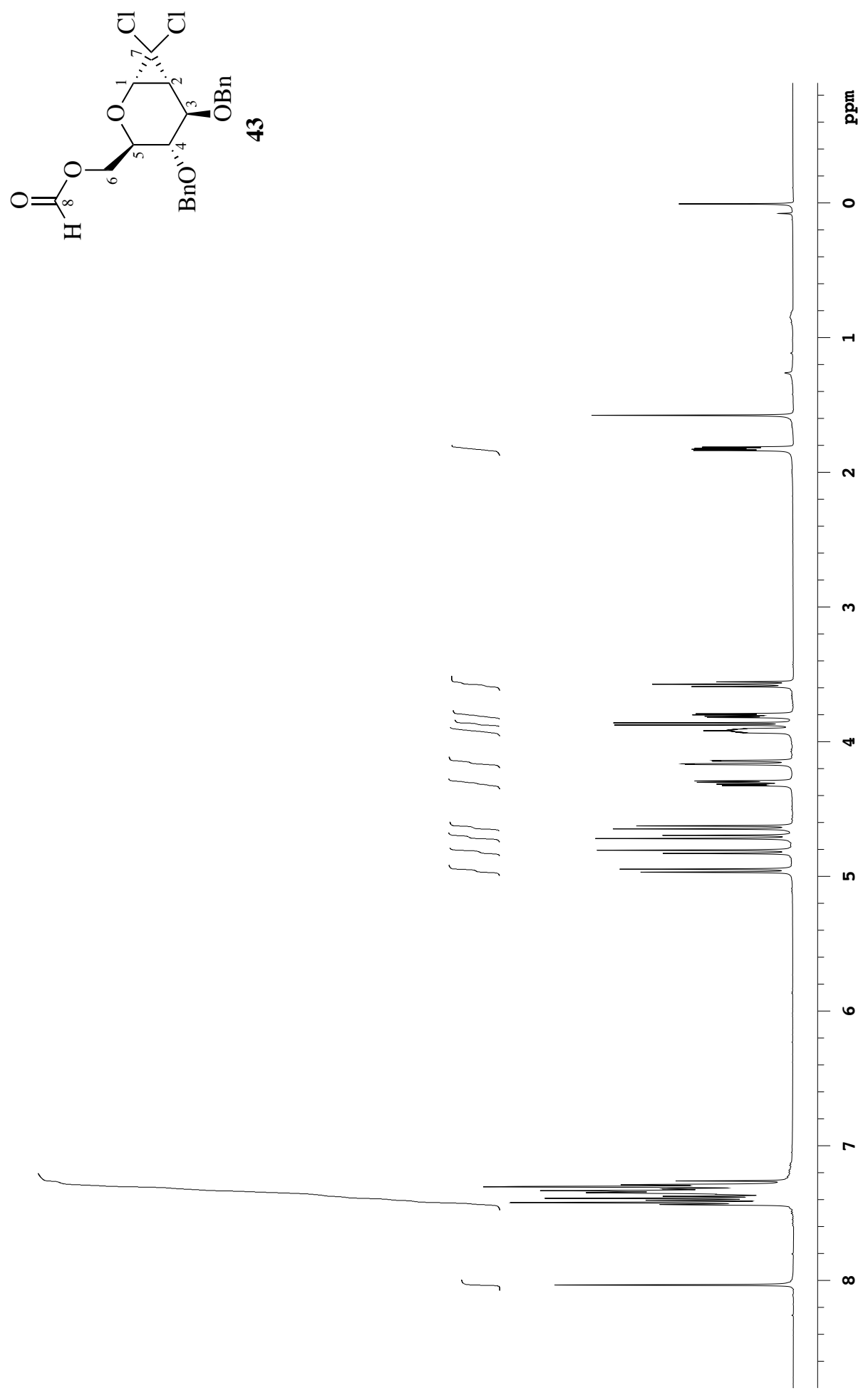

${ }^{1} \mathrm{H}$ NMR of the 1,2-cyclopropyl carbohydrate $43\left(500 \mathrm{MHz}, \mathrm{CDCl}_{3}\right)$ 

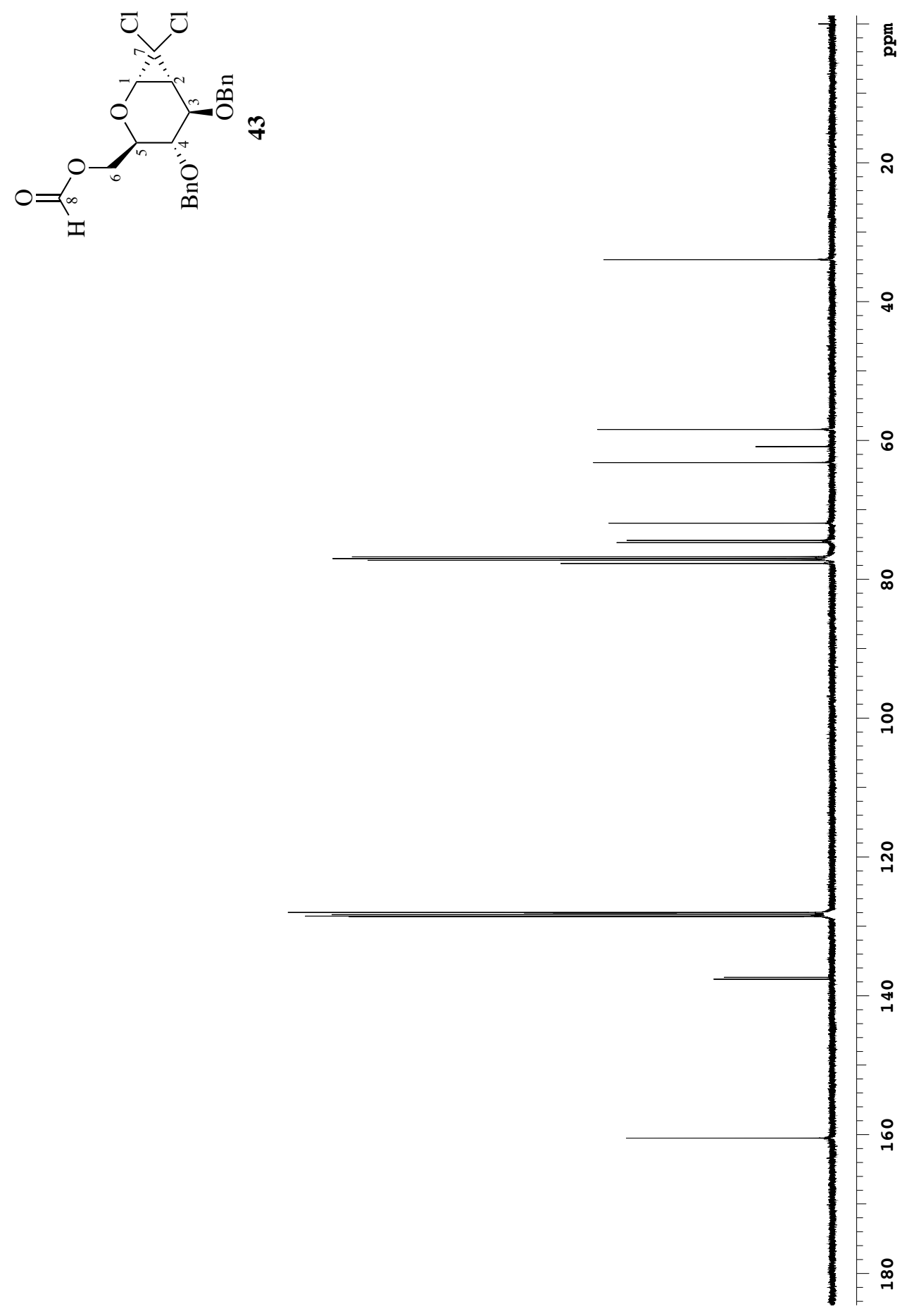

${ }^{13} \mathrm{C}$ NMR of the 1,2-cyclopropyl carbohydrate $43\left(500 \mathrm{MHz}, \mathrm{CDCl}_{3}\right)$ 

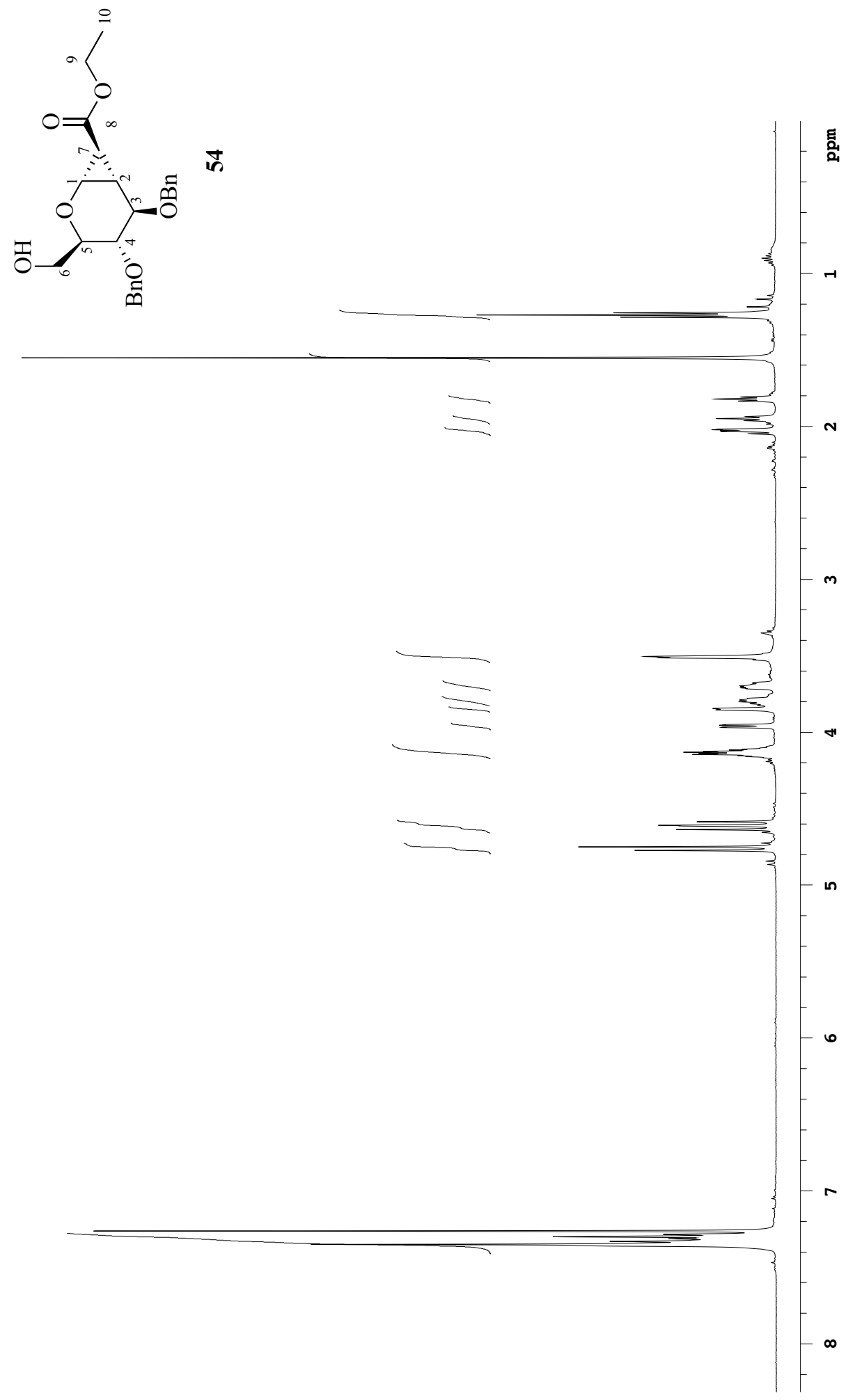

${ }^{1} \mathrm{H}$ NMR of the 1,2-cyclopropyl carbohydrate $54\left(500 \mathrm{MHz}, \mathrm{CDCl}_{3}\right)$ 

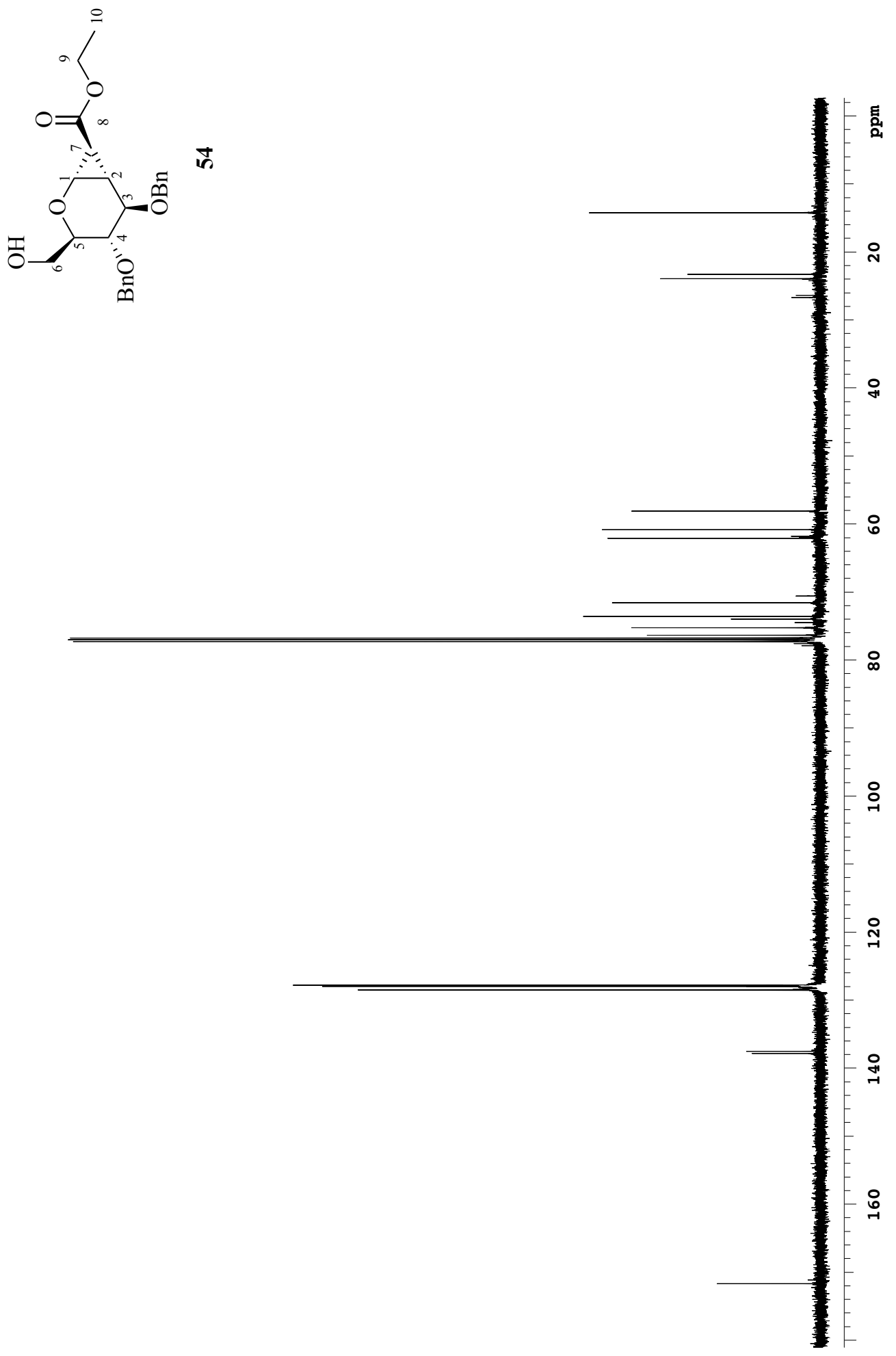

${ }^{13} \mathrm{C}$ NMR of the 1,2-cyclopropyl carbohydrate $54\left(500 \mathrm{MHz}, \mathrm{CDCl}_{3}\right)$ 

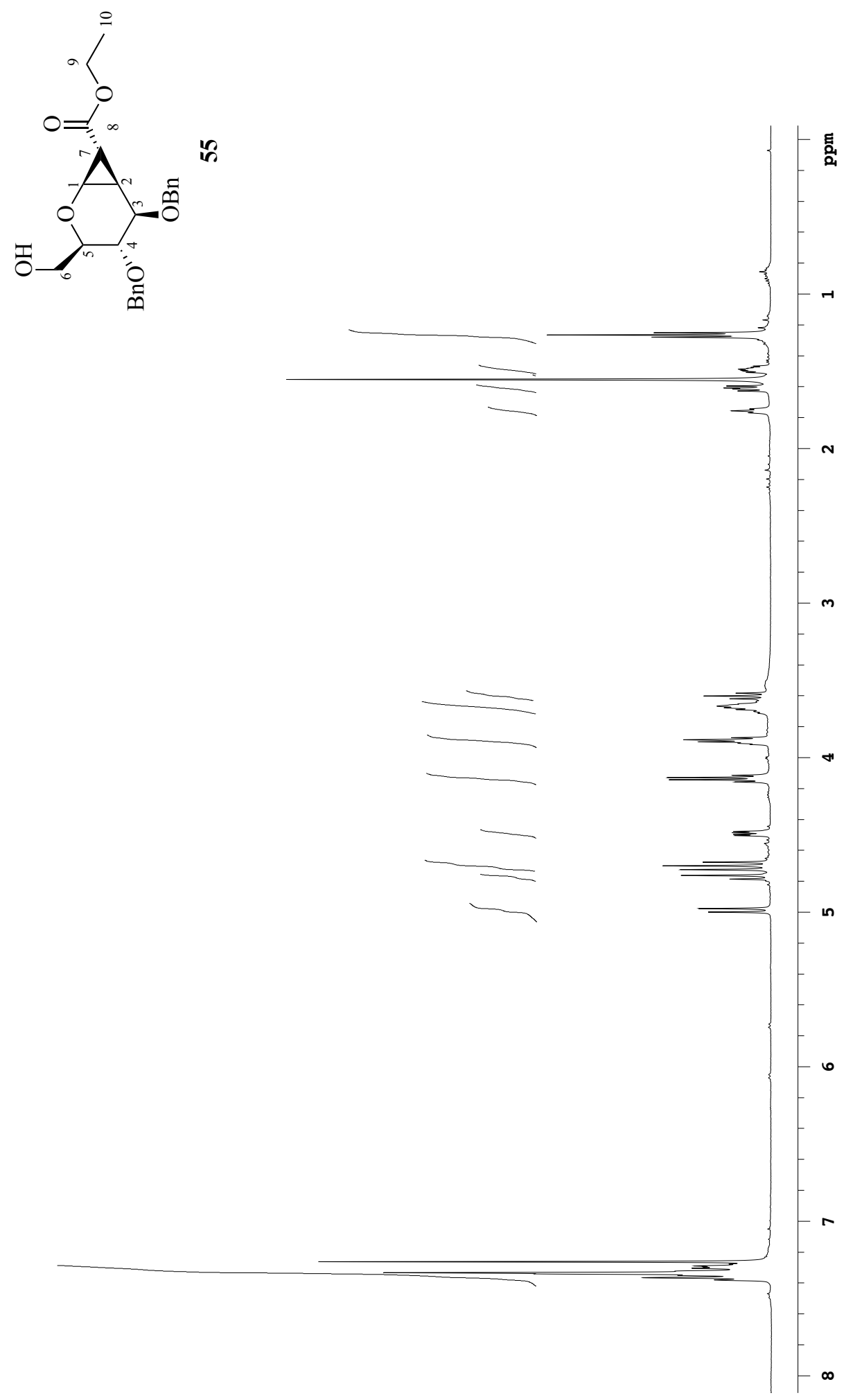

${ }^{1} \mathrm{H}$ NMR of the 1,2-cyclopropyl carbohydrate $55\left(500 \mathrm{MHz}, \mathrm{CDCl}_{3}\right)$ 

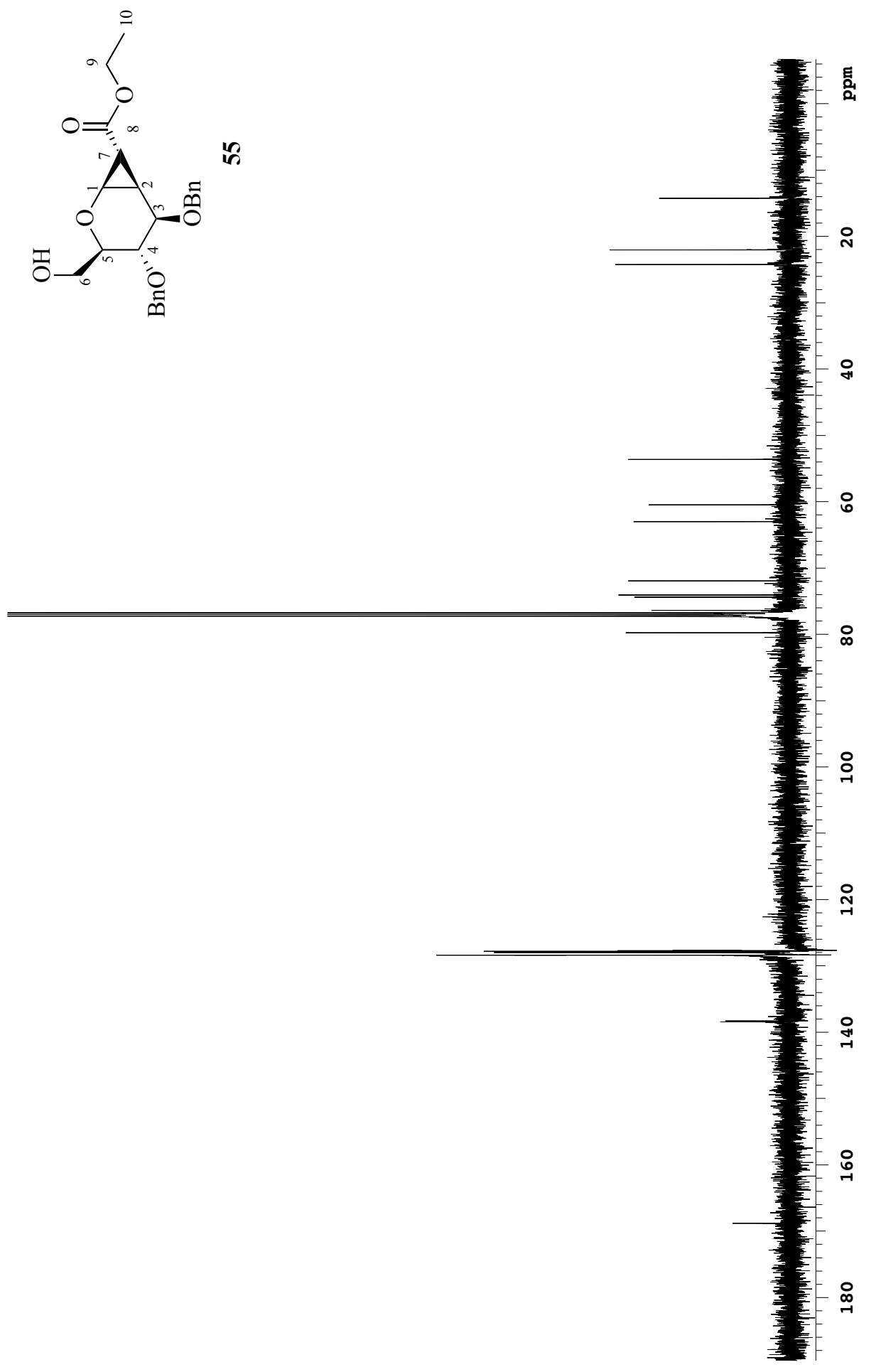

${ }^{13} \mathrm{C}$ NMR of the 1,2-cyclopropyl carbohydrate $55\left(500 \mathrm{MHz}, \mathrm{CDCl}_{3}\right)$ 

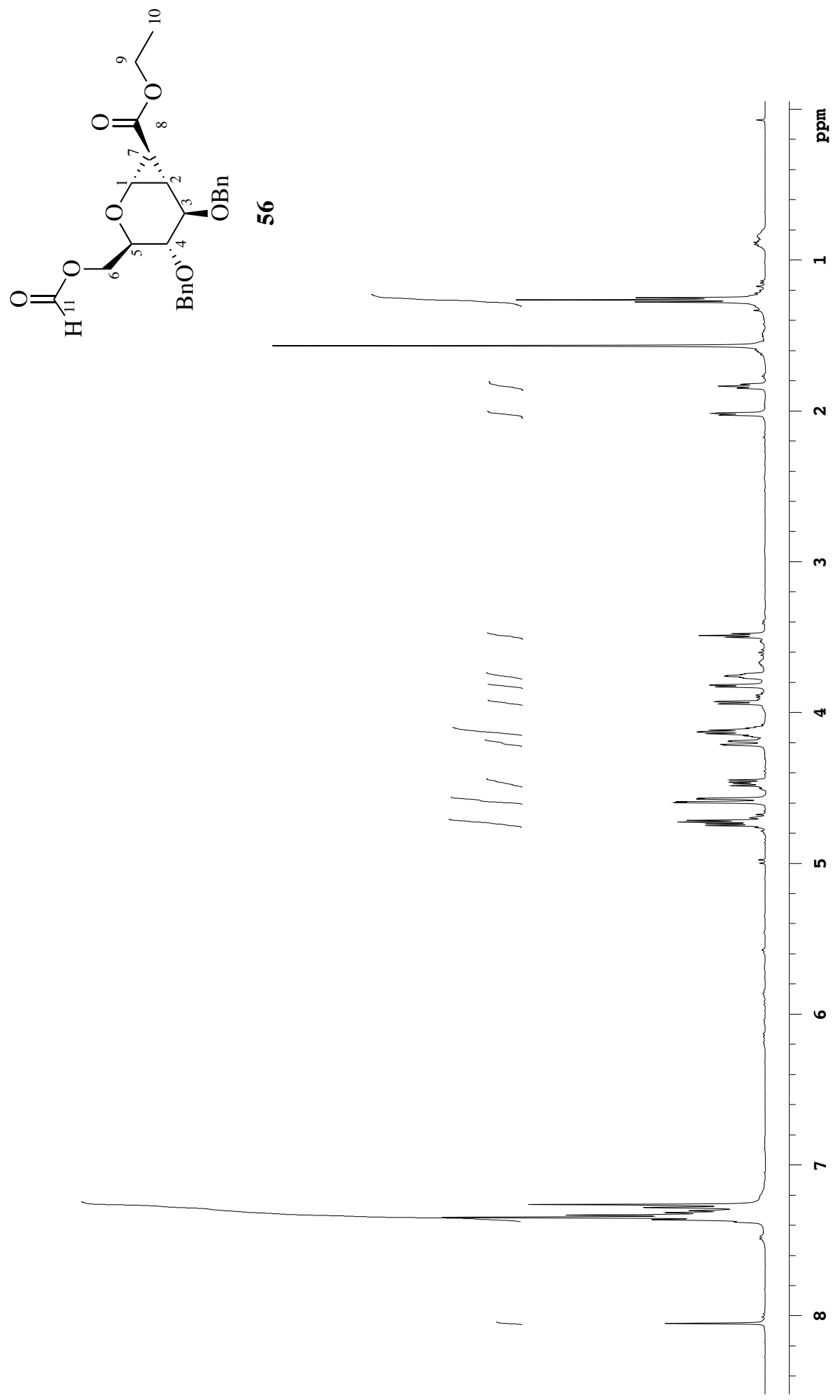

${ }^{1} \mathrm{H}$ NMR of the 1,2-cyclopropyl carbohydrate $\mathbf{5 6}\left(500 \mathrm{MHz}, \mathrm{CDCl}_{3}\right)$ 

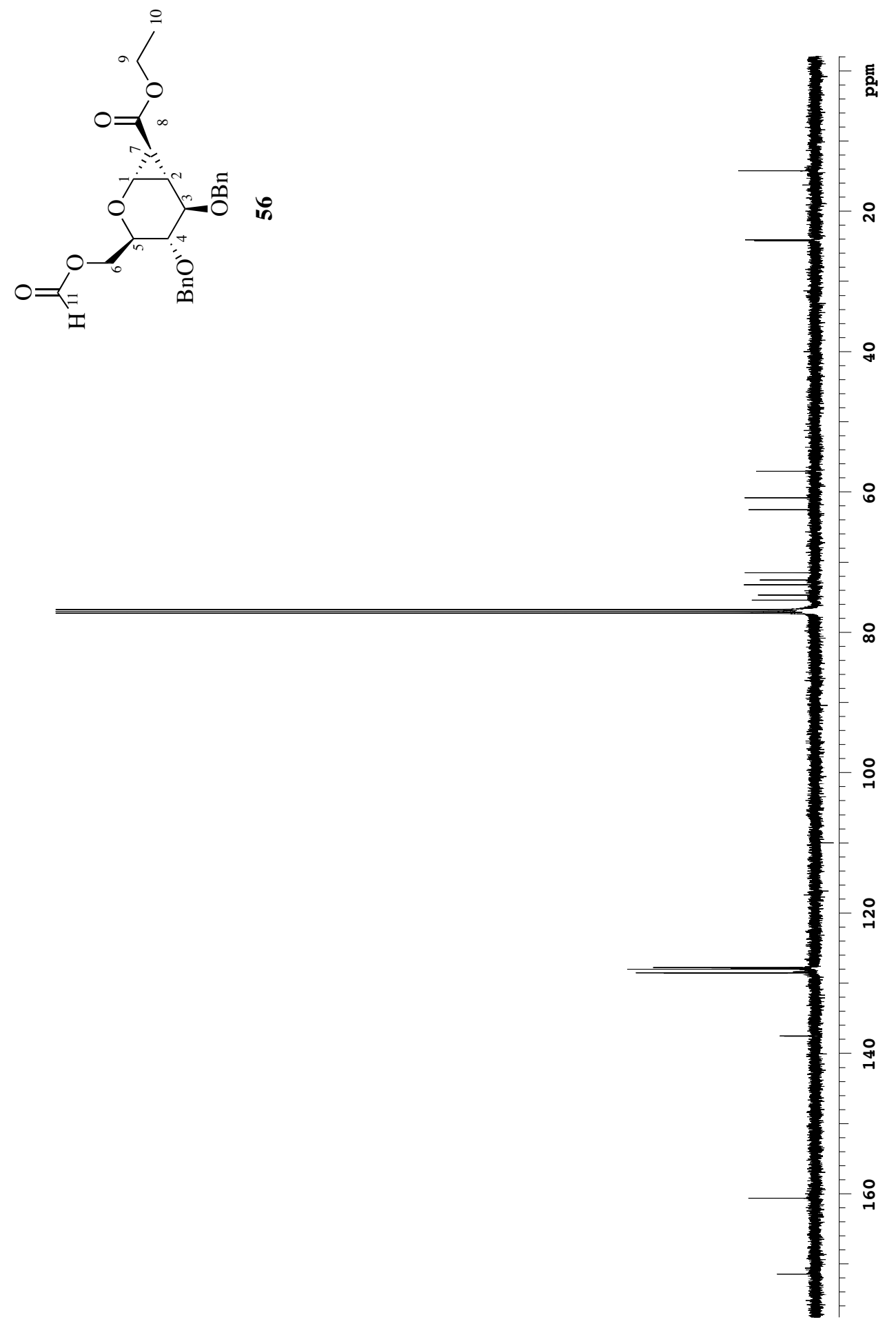

${ }^{13} \mathrm{C}$ NMR of the 1,2-cyclopropyl carbohydrate $56\left(500 \mathrm{MHz}, \mathrm{CDCl}_{3}\right)$ 

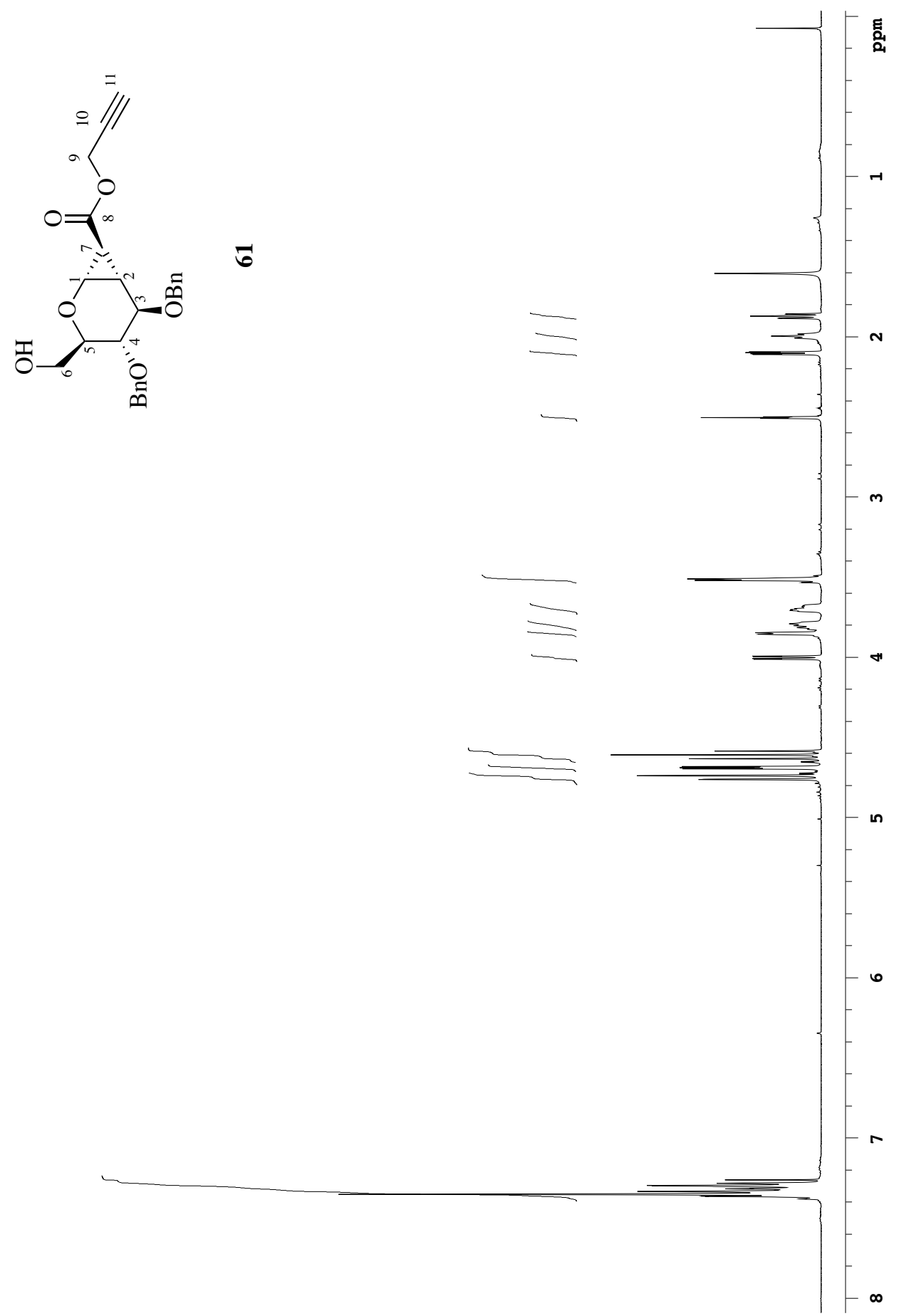

${ }^{1} \mathrm{H}$ NMR of the 1,2-cyclopropyl carbohydrate $61\left(500 \mathrm{MHz}, \mathrm{CDCl}_{3}\right)$ 


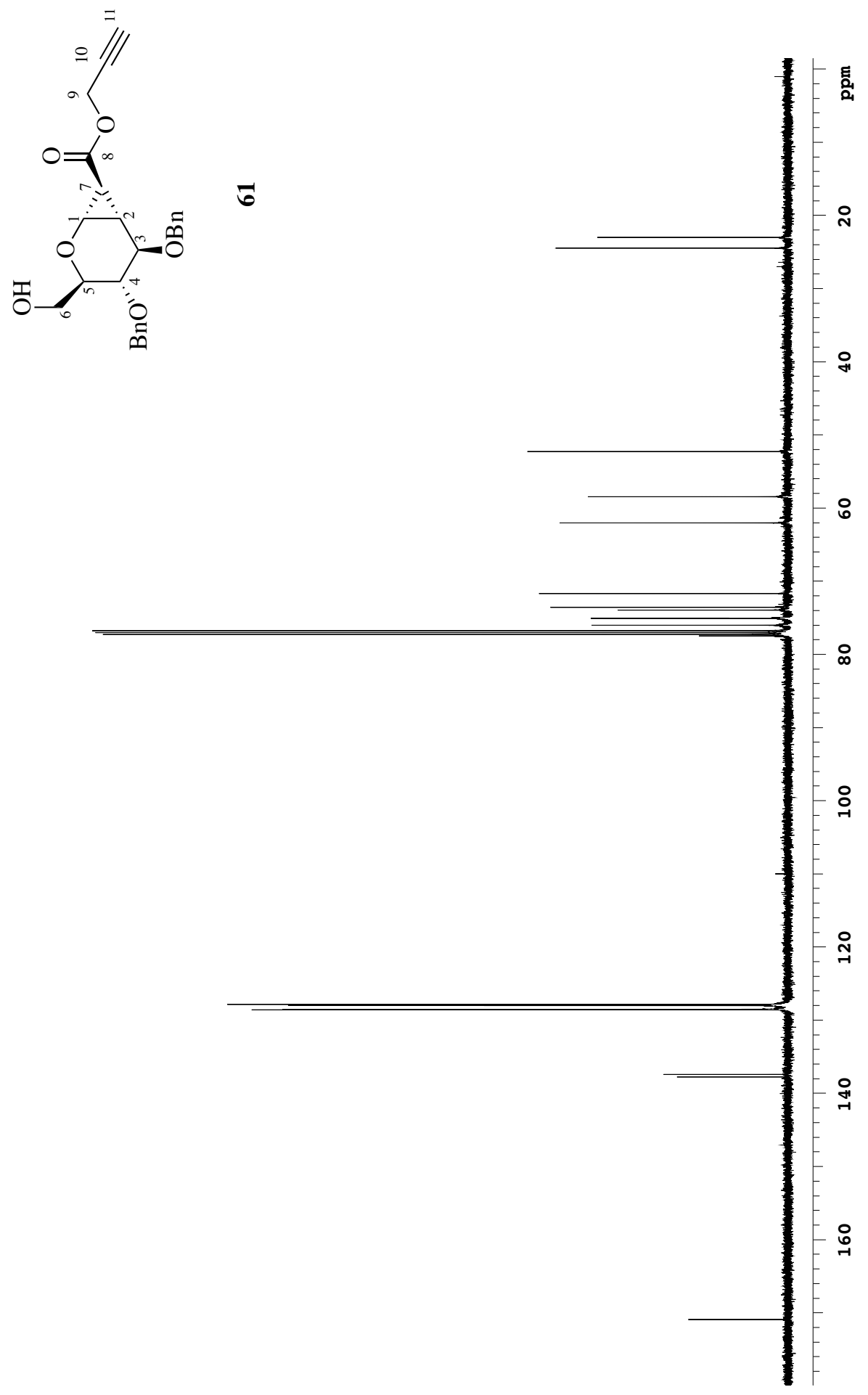

${ }^{13} \mathrm{C}$ NMR of the 1,2-cyclopropyl carbohydrate $61\left(500 \mathrm{MHz}, \mathrm{CDCl}_{3}\right)$ 

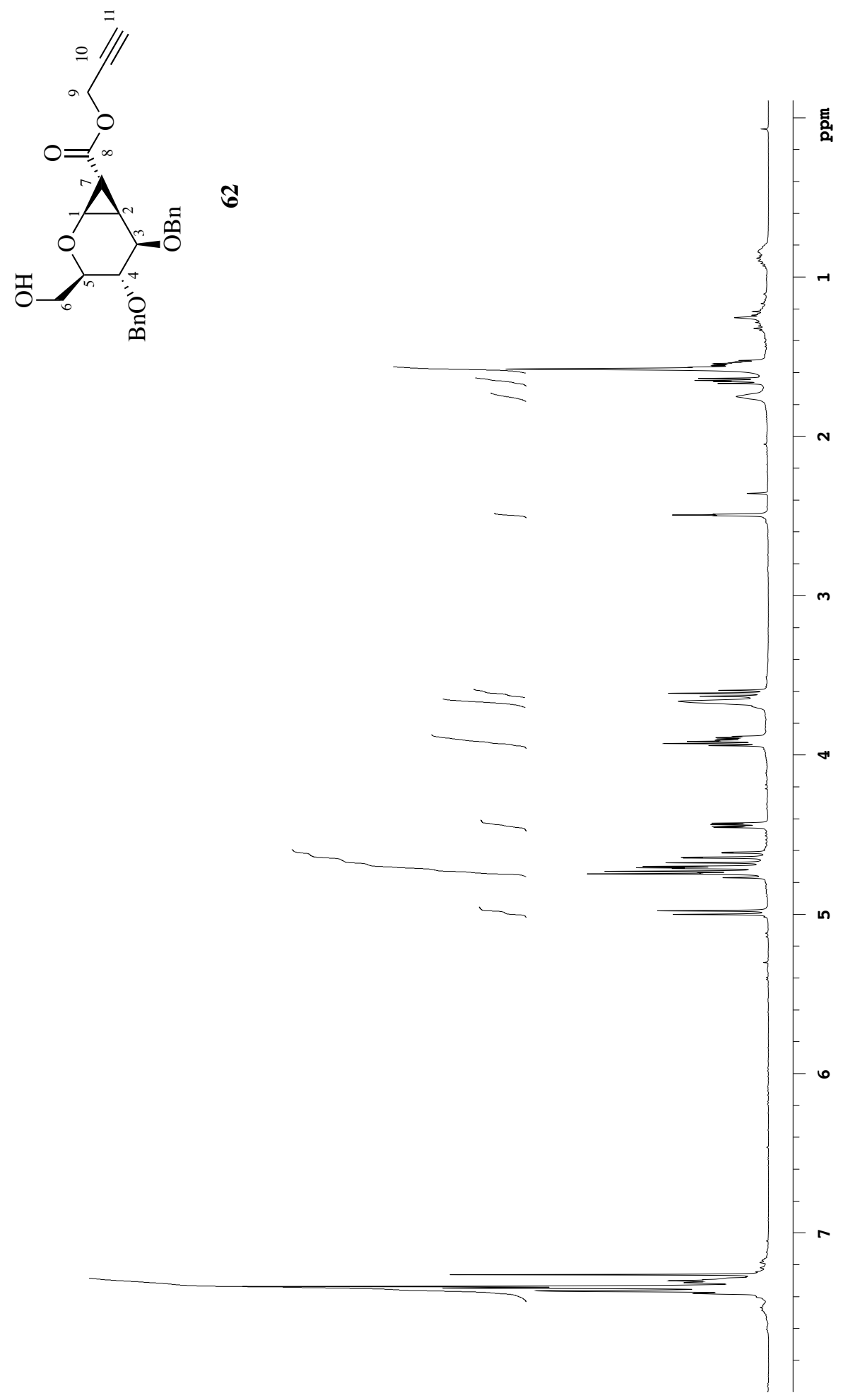

${ }^{1} \mathrm{H}$ NMR of the 1,2-cyclopropyl carbohydrate $62\left(500 \mathrm{MHz}, \mathrm{CDCl}_{3}\right)$ 

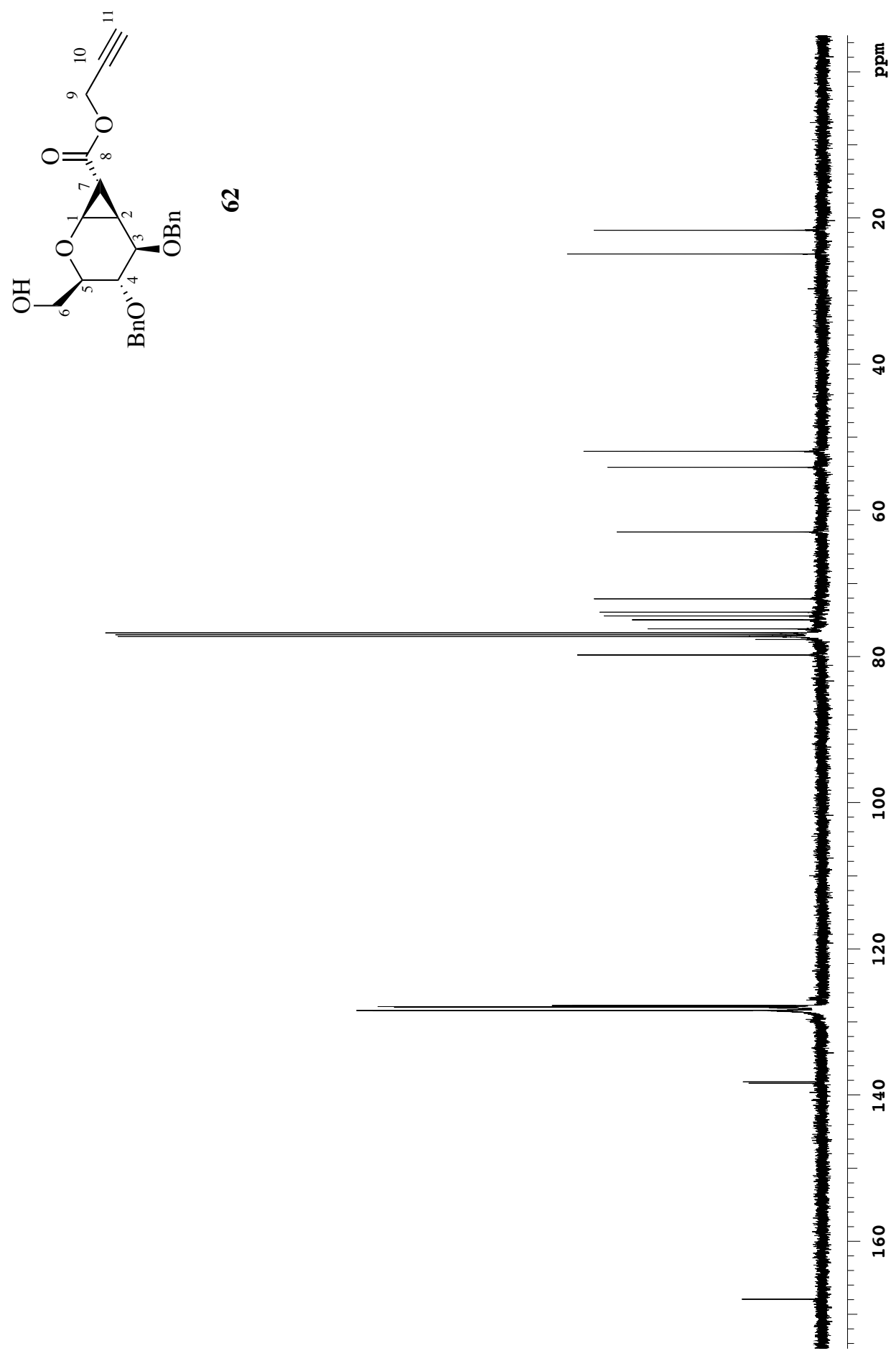

${ }^{13} \mathrm{C}$ NMR of the 1,2-cyclopropyl carbohydrate $62\left(500 \mathrm{MHz}, \mathrm{CDCl}_{3}\right)$ 


\section{Chemical genetic hits}

Resistant Validations

\begin{tabular}{|c|c|c|c|}
\multicolumn{4}{|c}{ Compound 23 } \\
ORF & Gene & ORF & Gene \\
\hline YBL027W & RPL19B & YGL212W & VAM7 \\
\hline YBR089C-A & NHP6B & YHL033C & RPL8A \\
\hline YBR161W & CSH1 & YML058W & SML1 \\
\hline YBR181C & RPS6B & YMR017W & SPO20 \\
\hline YBR266C & SLM6 & YMR085W & YMR085W \\
\hline YBR267W & REI1 & YNL147W & LSM7 \\
\hline YDL082W & RPL13A & YOR106W & VAM3 \\
\hline YDL121C & YDL121C & YPL086C & ELP3 \\
\hline YDL128W & VCX1 & YPL120W & VPS30 \\
\hline YDR005C & MAF1 & YPL178W & CBC2 \\
\hline YDR250C & YDR250C & YPR043W & RPL43A \\
\hline YDR375C & BCS1 & YGR055W & MUP1 \\
\hline YDR435C & PPM1 & & \\
\hline YEL013W & VAC8 & & \\
\hline YFL023W & BUD27 & & \\
\hline YFL036W & RPO41 & & \\
\hline YFR048W & RMD8 & & \\
\hline YGL024W & YGL024W & & \\
\hline YGL174W & BUD13 & & \\
\hline YGL175C & SAE2 & & \\
\hline YGR037C & ACB1 & & \\
\hline YGR206W & MVB12 & & \\
\hline YHL033C & RPL8A & & \\
\hline YHR081W & LRP1 & & \\
\hline YHR203C & RPS4B & & \\
\hline YIL138C & TPM2 & & \\
\hline YIR005W & IST3 & & \\
\hline YJR032W & CPR7 & & \\
\hline YJR050W & ISY1 & & \\
\hline & & & \\
\hline
\end{tabular}




\begin{tabular}{|c|c|l|l|}
\hline YLL045C & RPL8B & & \\
\hline YLR185W & RPL37A & & \\
\hline YLR234W & TOP3 & & \\
\hline YLR345W & YLR345W & & \\
\hline YLR346C & YLR346C & & \\
\hline YLR371W & ROM2 & & \\
\hline YML010C-B & YML010C-B & & \\
\hline YML035C & AMD1 & & \\
\hline YML058W & SML1 & & \\
\hline YML107C & PML39 & & \\
\hline YML129C & COX14 & & \\
\hline YMR017W & SPO20 & & \\
\hline YMR256C & COX7 & & \\
\hline YMR269W & TMA23 & & \\
\hline YMR269W & YMR269W & & \\
\hline YMR282C & AEP2 & & \\
\hline YNL147W & LSM7 & & \\
\hline YNL169C & PSD1 & & \\
\hline YNL171C & YNL171C & & \\
\hline YNL242W & ATG2 & & \\
\hline YNL246W & VPS75 & & \\
\hline YNL316C & PHA2 & & \\
\hline YOL089C & HAL9 & & \\
\hline YOL160W & YOL160W & & \\
\hline YOR085W & OST3 & & \\
\hline YPL080C & YPL080C & & \\
\hline YPL090C & RPS6A & & \\
\hline YPL157W & TGS1 & & \\
\hline YPL178W & CBC2 & & \\
\hline YPL222W & FMP40 & & \\
\hline YPR043W & RPL43A & & \\
\hline YPR191W & QCR2 & & \\
\hline
\end{tabular}

Table 4.0: Resistant validated strain 1 
Sensitive Validations

\begin{tabular}{|c|c|c|c|}
\hline \multicolumn{4}{|c|}{ Sesistant strains } \\
\hline \multicolumn{2}{|c|}{ Compound $\mathbf{2 3}$} & \multicolumn{2}{|c|}{ Compound $\mathbf{5 4}$} \\
\hline ORF & Gene & ORF & Gene \\
\hline YAL027W & SAW1 & YAL010C & MDM10 \\
\hline YAL028W & FRT2 & YAL027W & SAW1 \\
\hline YBL028C & YBL028C & YBL048W & RRT1 \\
\hline YBL047C & EDE1 & YBR022W & POA1 \\
\hline YBL048W & RRT1 & YBR036C & CSG2 \\
\hline YBR022W & POA1 & YBR089C-A & NHP6B \\
\hline YBR023C & CHS3 & YBR171W & SEC66 \\
\hline YBR036C & CSG2 & YBR283C & SSH1 \\
\hline YBR042C & CST26 & YDL006W & PTC1 \\
\hline YBR043C & QDR3 & YDL020C & RPN4 \\
\hline YBR150C & TBS1 & YDR058C & TGL2 \\
\hline YBR171W & SEC66 & YDR074W & TPS2 \\
\hline YBR175W & SWD3 & YDR127W & ARO1 \\
\hline YBR194W & AIM4 & YDR207C & UME6 \\
\hline YBR283C & SSH1 & YEL031W & SPF1 \\
\hline YCL045C & EMC1 & YER090W & TRP2 \\
\hline YCL046W & YCL046W & YFL032W & YFL032W \\
\hline YCR020C-A & MAK31 & YGL005C & COG7 \\
\hline YDL006W & PTC1 & YGL023C & PIB2 \\
\hline YDL020C & RPN4 & YGL133W & ITC1 \\
\hline YDL199C & YDL199C & YGR028W & MSP1 \\
\hline YDR056C & YDR056C & YGR080W & TWF1 \\
\hline YDR057W & YOS9 & YGR157W & $\mathrm{CHO} 2$ \\
\hline YDR058C & TGL2 & YGR188C & BUB1 \\
\hline YDR072C & IPT1 & YIL030C & SSM4 \\
\hline YDR074W & TPS2 & YIL036W & CST6 \\
\hline YDR123C & INO2 & YJL029C & VPS53 \\
\hline YDR127W & ARO1 & YJL192C & SOP4 \\
\hline
\end{tabular}




\begin{tabular}{|l|l|l|l|}
\hline YDR183W & PLP1 & YJR040W & GEF1 \\
\hline YDR199W & YDR199W & YJR059W & PTK2 \\
\hline YDR294C & DPL1 & YJR087W & YJR087W \\
\hline YDR297W & SUR2 & YJR088C & EMC2 \\
\hline YDR304C & CPR5 & YKL081W & TEF4 \\
\hline YDR305C & HNT2 & YKL207W & EMC3 \\
\hline YDR326C & YSP2 & YKR020W & VPS51 \\
\hline YEL031W & SPF1 & YKR072C & SIS2 \\
\hline YER002W & NOP16 & YKR082W & NUP133 \\
\hline YER019C-A & SBH2 & YLL014W & EMC6 \\
\hline YFL032W & YFL032W & YLR262C & YPT6 \\
\hline YFR024C-A & LSB3 & YLR338W & OPI9 \\
\hline YFR039C & OSW7 & YML013W & UBX2 \\
\hline YGL005C & COG7 & YML071C & COG8 \\
\hline YGL051W & MST27 & YML097C & VPS9 \\
\hline YGL085W & LCL3 & YMR123W & PKR1 \\
\hline YGL132W & YGL132W & YNL051W & COG5 \\
\hline YGL133W & ITC1 & YNL231C & PDR16 \\
\hline YGL230C & YGL230C & YNL257C & SIP3 \\
\hline YGL231C & EMC4 & YNR019W & ARE2 \\
\hline YGL261C & PAU11 & YNR021W & YNR021W \\
\hline YGR017W & YGR017W & YOR026W & BUB3 \\
\hline YGR028W & MSP1 & YOR216C & RUD3 \\
\hline YGR079W & YGR079W & YPR060C & ARO7 \\
\hline YGR080W & TWF1 & YPR170C & YPR170C \\
\hline YGR093W & DRN1 & & \\
\hline YGR100W & MDR1 & & \\
\hline YGR111W & YGR111W & & \\
\hline YGR123C & PPT1 & & \\
\hline YGR157W & CHO2 & & \\
\hline YGR188C & BUB1 & & \\
\hline YIR007W & & \\
\hline YJ029C & & & \\
\hline
\end{tabular}




\begin{tabular}{|l|l|l|l|}
\hline YJL095W & BCK1 & & \\
\hline YJL134W & LCB3 & & \\
\hline YJL135W & YJL135W & & \\
\hline YJL150W & YJL150W & & \\
\hline YJL192C & SOP4 & & \\
\hline YJR040W & GEF1 & & \\
\hline YJR073C & OPI3 & & \\
\hline YJR087W & YJR087W & & \\
\hline YJR088C & EMC2 & & \\
\hline YJR108W & ABM1 & & \\
\hline YJR110W & YMR1 & & \\
\hline YJR145C & RPS4A & & \\
\hline YKL063C & YKL063C & & \\
\hline YKL081W & TEF4 & & \\
\hline YKL207W & EMC3 & & \\
\hline YKR020W & VPS51 & & \\
\hline YKR029C & SET3 & & \\
\hline YKR082W & NUP133 & & \\
\hline YLL014W & EMC6 & & \\
\hline YLR058C & SHM2 & & \\
\hline YLR262C & YPT6 & & \\
\hline YLR337C & VRP1 & & \\
\hline YLR338W & OPI9 & & \\
\hline YLR374C & YLR374C & & \\
\hline YLR415C & YLR415C & & \\
\hline YLR454W & FMP27 & & \\
\hline YML013W & UBX2 & & \\
\hline YML052W & SUR7 & & \\
\hline YML071C & COG8 & & \\
\hline YML097C & VPS9 $1 ~$ & & \\
\hline YML106W & URA5 & & \\
\hline YMR102C & YMR102C & & \\
\hline YMR123W & & \\
\hline
\end{tabular}




\begin{tabular}{|l|l|l|l|}
\hline YMR304W & UBP15 & & \\
\hline YNL051W & COG5 & & \\
\hline YNL079C & TPM1 & & \\
\hline YNL162W & RPL42A & & \\
\hline YNL231C & PDR16 & & \\
\hline YNL238W & KEX2 & & \\
\hline YNL257C & SIP3 & & \\
\hline YNR019W & ARE2 & & \\
\hline YNR021W & YNR021W & & \\
\hline YNR031C & SSK2 & & \\
\hline YOL087C & DUF1 & & \\
\hline YOR006C & TSR3 & & \\
\hline YOR026W & BUB3 & & \\
\hline YOR216C & RUD3 & & \\
\hline YOR265W & RBL2 & & \\
\hline YPL108W & YPL108W & & \\
\hline YPL171C & OYE3 & & \\
\hline YPR170C & YPR170C & & \\
\hline
\end{tabular}

Table 4.1: Sensitive validated strain 1 